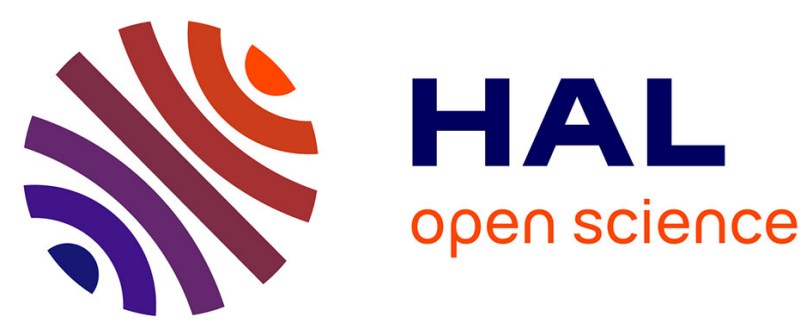

\title{
Gram-scale synthesis of luciferins derived from coelenterazine and original insights into their bioluminescence properties
}

Eloi Coutant, Sophie Goyard, Vincent Hervin, Glwadys Gagnot, Racha Baatallah, Yves Jacob, Thierry Rose, Yves Louis Janin

\section{To cite this version:}

Eloi Coutant, Sophie Goyard, Vincent Hervin, Glwadys Gagnot, Racha Baatallah, et al.. Gram-scale synthesis of luciferins derived from coelenterazine and original insights into their bioluminescence properties. Organic \& Biomolecular Chemistry, 2019, 15, 10.1039/c9ob00459a . pasteur-02072739

\section{HAL Id: pasteur-02072739}

\section{https://hal-pasteur.archives-ouvertes.fr/pasteur-02072739}

Submitted on 23 Oct 2019

HAL is a multi-disciplinary open access archive for the deposit and dissemination of scientific research documents, whether they are published or not. The documents may come from teaching and research institutions in France or abroad, or from public or private research centers.
L'archive ouverte pluridisciplinaire HAL, est destinée au dépôt et à la diffusion de documents scientifiques de niveau recherche, publiés ou non, émanant des établissements d'enseignement et de recherche français ou étrangers, des laboratoires publics ou privés. 


\section{Gram-Scale Synthesis of Luciferins Derived from Coelenterazine and Original Insights in Their Bioluminescence Properties}

Eloi P. Coutant Sophie Goyard Vincent Hervin Glwadys Gagnot Racha Baatallah Yves Jacob Thierry Rose* and Yves L. Janin*

An original gram-scale synthesis of O-acetylated forms of coelenterazine, furimazine or hydroxybearing analogues of these luciferins is described. The comparisons over two hours of their bioluminescence, using the nanoKAZ/NanoLuc luciferase, is providing remarkable insights useful for the selection of a substrate adapted for a given application.

\section{Introduction}

Bioluminescence is based on the combination of at least oxygen, a small chemical cofactor and an enzyme. As depicted in scheme 1, extensive research, ${ }^{1}$ led to the discovery that many seadwelling bioluminescent species ${ }^{2,3}$ are using coelenterazine (CTZ, 1) or varguline (2) and harbor a large variety of luciferases or photoproteins (which are calcium-dependent luciferases) to produce light with these. Across the years, because of the many uses of bioluminescence-based tools in life sciences, ${ }^{4-10}$ attempts were made to improve the signal intensity, duration and/or the emission wavelength. This started with the isolation of a wide range of coelenterazine-using luciferases and their combination with analogues of coelenterazine (1). It then moved to the analysis of the effect of luciferase mutations on the bioluminescence properties and the best results obtained so far were achieved by the association of mutated luciferases and luciferins analogues. ${ }^{11-25}$ It is the combinations of an extensively mutated form of the catalytic subunit of Oplophorus gracilirostris luciferase (nanoKAZ/NanoLuc) ${ }^{20,}{ }^{21}$ and furimazine (3),20 or bisdeoxycoelenterazine (bis-CTZ, 4), ${ }^{21}$ which appears to be the current state of the art in regard with signal intensity and duration. 


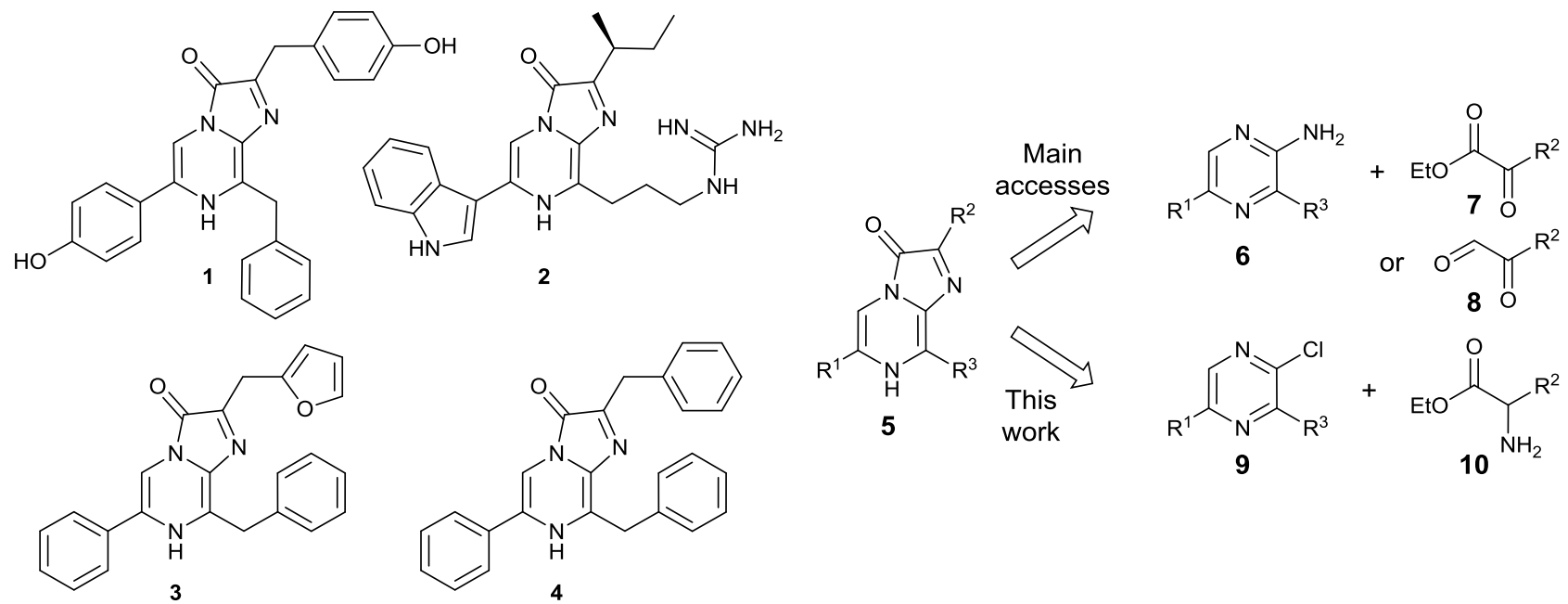

Scheme 1. Structures of coelenterazine (1), varguline (2), furimazine (3), and bisdeoxycoelenterazine (4) and retrosynthesis of imidazo[1,2-a]pyrazine-3(7H)-ones.

Concerning the chemistry of these luciferins, they are oxygen-sensitive and readily decompose in solution especially in the presence of a base, or upon light exposure. ${ }^{26}$ As depicted above, many ${ }^{27}$ if not all ${ }^{28-30}$ the reported preparations of imidazo[1,2-a]pyrazin-3(7H)-ones 5 are requiring an aminopyrazine (6) prior to the construction of the imidazole ring via a condensation with $\alpha$ ketoesters (7) or $\alpha$-ketoaldehydes (8). Recent improvements have extended this access to original luciferins ${ }^{24,26}$ but to avoid some of its inherent limitations, we focused on an alternative initially explored on a model compound. ${ }^{31}$ This path not only avoids the use of the non-trivial intermediates 7-8, but it also offers, via a key $\mathrm{N}$-arylation of halogenopyrazines (9), the recourse to a wide range of the far more available $\alpha$-amino esters (10). ${ }^{32-34}$ As depicted in scheme 2 , an original preparation of chloropyrazines 9a-c was achieved starting with a 1,4-addition reaction between $\beta$-nitrostyrenes 11a-c and phenylalanine ethyl ester (12). 


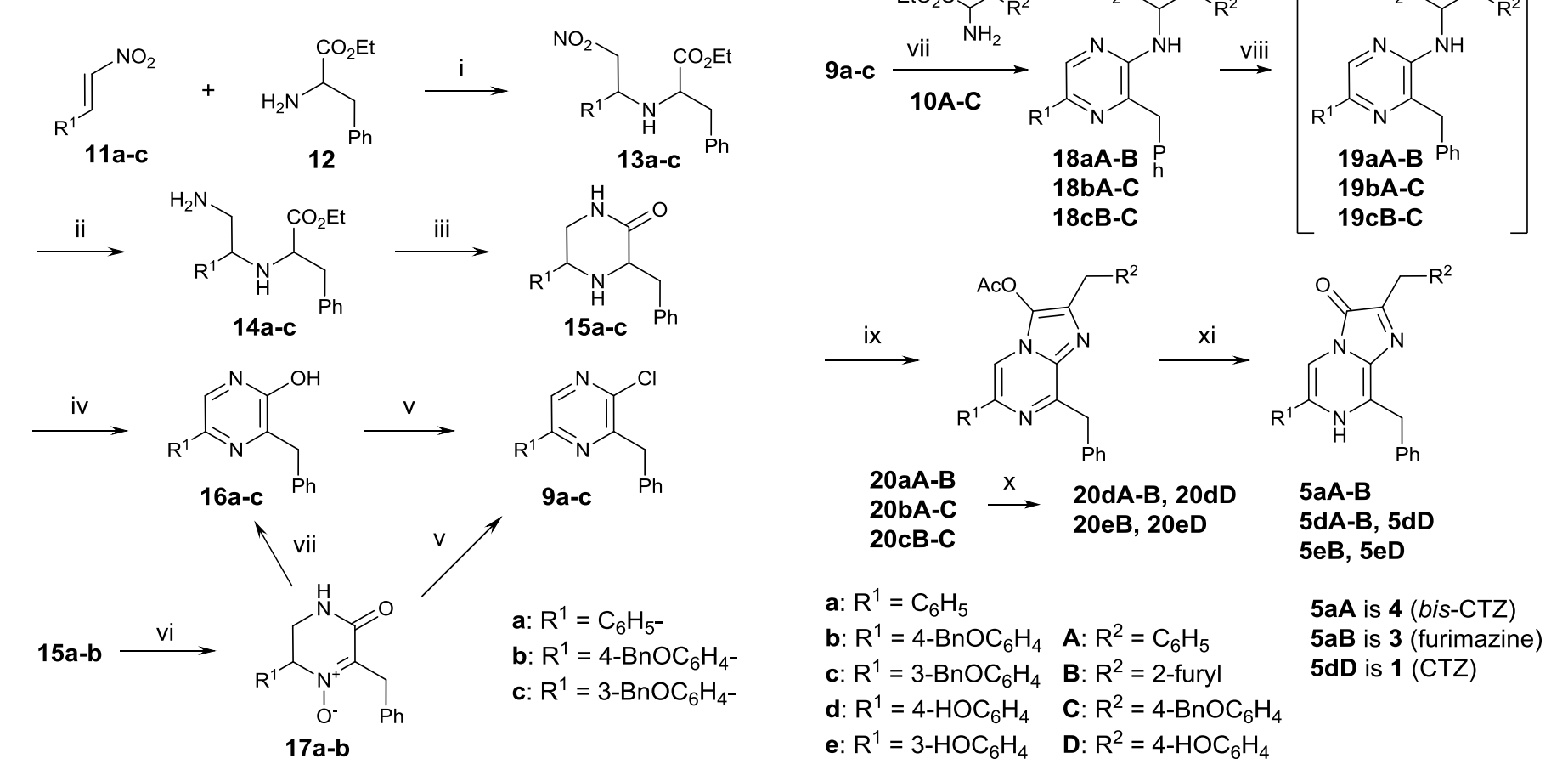

Scheme 2. i: neat. ii: $\mathrm{Zn}, \mathrm{H}_{3} \mathrm{O}^{+}, \mathrm{Cl}^{-}$, dioxane. iii: $130{ }^{\circ} \mathrm{C}$, neat. iv: $\mathrm{S}_{8}, 1,3-\mathrm{Cl}_{2} \mathrm{C}_{6} \mathrm{H}_{4}$, reflux. v: $\mathrm{PhPOCl}_{2}, 100{ }^{\circ} \mathrm{C}$. vi: $\mathrm{AcOOH}$, AcOEt. vii: chlorobenzene, reflux or $\mathrm{NaOH}, \mathrm{EtOH}$, reflux. . vii: $\mathrm{Cs}_{2} \mathrm{CO}_{3}, \mathrm{Pd}(\mathrm{OAc})_{2}$, BINAP, $\mathrm{MeCN}, 60^{\circ} \mathrm{C}$. viii: $\mathrm{NaOH}$, THF, $20^{\circ} \mathrm{C}$. ix: $\mathrm{Ac}_{2} \mathrm{O}, 20^{\circ} \mathrm{C}$. x: H2, $\mathrm{Pd} / \mathrm{C}, \mathrm{AcOEt}, \mathrm{AcOH}, \mathrm{EtOH}$. xi: EtOH, DMSO, $\mathrm{H}_{3} \mathrm{O}^{+}, \mathrm{Cl}^{-}, 50{ }^{\circ} \mathrm{C}$.

Until recently, ${ }^{35}$ there were only very few precedents for this reaction, ${ }^{36-41}$ probably because of a lack of such 1,4-addition in solution. Indeed, in our cases, it is only when removing the solvent that the 1,4 adducts 13a-c were formed. The use of zinc and hydrochloric acid in dioxane for their reduction provided an access to the diamines 14a-c including a compatibility with the benzyloxy groups of 13b-c. Their cyclization to give the (separable) piperazinone diastereoisomers 15a-c was then achieved with heat. The previously unreported use of sulfur as an oxidant was initially essential for their aromatization into the corresponding hydroxypyrazines 16a-c. Later on, we found an alternative via an original dehydration of the N-oxide 17a-b (obtained by the peroxyacetic acid treatment of $\mathbf{1 5 a - b}$ ) using either heat or more preferably sodium hydroxide. Finally, from the hydroxypyrazines 16a-c, hot phenylphosphonic dichloride ${ }^{42}$ was essential to prepare the chloropyrazines $9 \mathbf{9 a - c}$, and this reagent could also be used to directly transform, for instance, N-oxide 17a into the chloropyrazine 9a. This was followed by the key BuchwaldHartwig palladium-catalyzed $\mathrm{N}$-arylation of the readily available ${ }^{33,34} \alpha$-amino esters $\mathbf{1 0 A}-\mathbf{C}$ by chloropyrazines 9a-c. Starting from related precedents, ${ }^{43-48}$ it quickly turned out that a mild temperature was required. The best conditions we found, $60{ }^{\circ} \mathrm{C}$ in acetonitrile with cesium carbonate for 12 hours using BINAP and palladium(II) acetate, led to the $\mathrm{N}$-arylesters 18 in 69$90 \%$ yields. For the next step, we observed that the inherent instability of the target luciferins 5aB limited its purification to a precipitation. To avoid this, we prepared the far more stable Oacetylated derivatives 20 in one pot from the $\mathrm{N}$-arylesters $\mathbf{1 8}$ via the acid salts $\mathbf{1 9}$, generated in situ, and an ensuing treatment with an excess of acetic anhydride. These pro-luciferins turned out 
to be stable enough to withstand a chromatography but, even better, a simple recrystallization provided compounds 20aA-B in up to grams amount. For the synthesis of the phenol-bearing luciferins, a catalytic hydrogenation of O-benzyl-bearing compounds 20bA-bC and 20cB-cC provided the corresponding O-acetylated luciferins 20dA-dB, 20dD, 20eB and 20eD. Then, as seen by LC/MS (supporting information, figure S1), a treatment of these O-acetylated luciferins 20 with a mixture of hydrochloric acid, ethanol and DMSO at $50{ }^{\circ} \mathrm{C}$ provided concentrated solutions of the pure luciferins $\mathbf{5}$ which could be used immediately, upon a dilution in the relevant buffer, or stored at low temperature. As depicted in figure 2, and described in the supporting information section, the bioluminescence properties of these luciferins were then studied using a purified recombinant nanoKAZ/NanoLuc luciferase. In comparison with the very low intensity of coelenterazine (1), or for that matter "isocoelenterazine" (5eD), furimazine (3) and bisdeoxycoelenterazine (4) were, as previously reported, ${ }^{20}, 21$ providing vastly improved bioluminescence signals lasting at least two hours. Interestingly, the two monohydroxy-bearing analogues h-coelenterazine $(\mathbf{5 d A})$ and $\mathbf{5 d B}$ led to at least twice more intense signals but which lasted only minutes (figure 2B). Such initial intensity has actually been reported before for hcoelenterazine $(\mathbf{5 d A}) .{ }^{21}$ On the other hand, the isomeric mono hydroxy-bearing compound 5eB displayed a far more stable bioluminescence profile pretty much identical with the one observed for furimazine (3). With all these luciferins, the light intensity decreased with time: rather quickly for the "flash" and much more slowly for the "glow" substrates. For the "flash" substrates, luciferins $\mathbf{5} \mathbf{d A}$ and $\mathbf{5} \mathbf{d B}$, the decrease fitted with a first order equation.



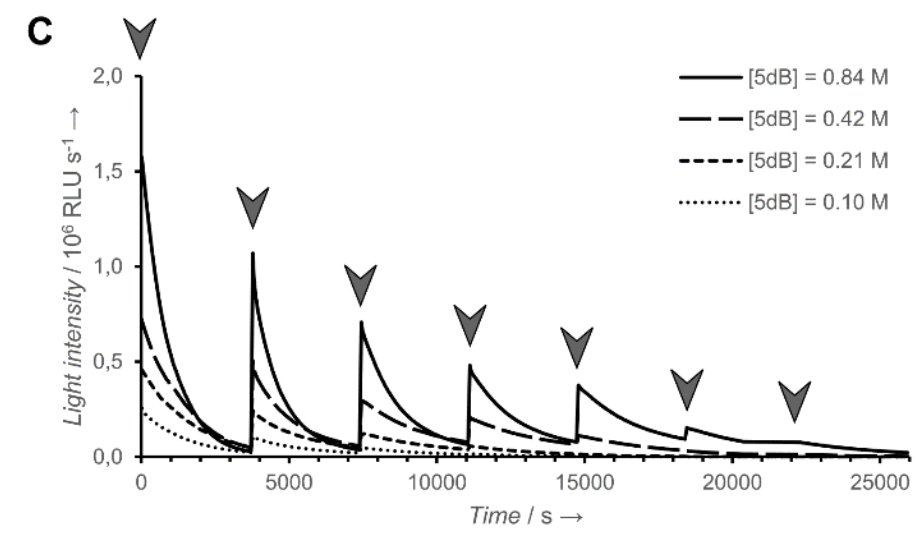

Figure 2. Bioluminescence signals of the luciferins 5 using recombinant nanoKAZ/NanoLuc. (A) Luciferin structures; compounds 1, 3, and 4 are depicted in figure 1. (B) Light intensity in RLU s-1 plotted vs. time over two hours, the insert zooms on the first two minutes of the reaction. (C) Bioluminescence profiles of compound $5 \mathrm{~dB}$ at different concentrations along with the repeated addition (arrows) of luciferase.

Adding further substrate after losing $90 \%$ of the initial light emission intensity did not, at best, produce any changes and could even causes a decrease of the remaining signal intensity. On the other hand, as depicted in figure $2 \mathrm{C}$, adding instead the same amount of enzyme used at the start led to a recovery of the signal. For the others substrates, this enzyme death was less pronounced but took place anyway (see supporting information).

Accordingly, the enzyme is irreversibly inactivated by a reaction product in all the cases with a constant ( $\mathrm{k}_{\text {inact }}$ ) dependent on the substrate used. Of note is that when all the substrate has been consumed, the area below these curves is providing a molecules consumed per RLU produced ratio (see table 1). Concerning the kinetics of these reactions, they are fitting with a MichaelisMenten model, if we assume that the number of detected photons per consumed substrate molecule is constant whatever the substrate concentration (see the supporting information for a discussion). The $K_{M}$ and $V_{\max }$ values were computed considering: 1) the luciferins (S) as the limiting substrates, $\mathrm{O}_{2}$ as saturating substrate 2) an inhibition of the enzyme E by excess of substrate through the binding of a second substrate (ESS) on the Michaelis' complex (ES) with the dissociation constant $\mathrm{K}_{\mathrm{I}}$ and 3 ) a stochastic inactivation of the enzyme ( $\left.\mathrm{E}^{*}\right)$ with the kinetic constant $\mathrm{k}_{\text {inact. }}$ As seen in table 1 and figure 3, coelenterazine (1) has a very high $\mathrm{k}_{\text {cat }}$ but a poor photon emission efficiency. Interestingly, furimazine (3) and its isomer $\mathbf{5 e B}$ are the most efficient photon emitter per substrate molecule catalysis with the same $\mathrm{k}_{\text {cat }}$ but furimazine (3) is somehow providing a longer life time of active enzyme (low $\mathrm{k}_{\text {inact }}$ ). All substrates are sensitive to substrate concentration beyond the $\mathrm{K}_{\mathrm{M}}$, but two luciferins, coelenterazine (1) and $\mathbf{5 e D}$, are more affected than others as seen with their low dissociation constants $\left(\mathrm{K}_{\mathrm{I}}\right)$. Of note is that the strong light intensity produced by the catalyzed oxidation of $\mathbf{5} \mathbf{d B}$ in a very short time (flash) does not mean the production of a high level of light intensity cumulated in two hours $(\Sigma \mathrm{I})$ and the very long half-life $\left(\mathrm{t}_{1 / 2}\right)$ with low light intensity (glow) provided by compound 5eD neither. Among these substrates, furimazine (3) is, so far, providing the best compromise. Also quite unexpected is the reason behind the fact that the natural substrate coelenterazine (1) leads to a signal two orders of magnitudes less intense than furimazine (3). Indeed, it is not because of a lesser catalytic activity 
but it is mostly due to a pretty much counter intuitive lesser number of photons detected by luciferin consumed.

\begin{tabular}{|c|c|c|c|c|c|c|c|}
\hline \multicolumn{8}{|c|}{ Table 1. Kinetic parameters for each substrate. } \\
\hline & 3 & 4 & 5dA & 5dB & 1 & $5 \mathrm{eB}$ & 5eD \\
\hline \multicolumn{8}{|l|}{ Imax } \\
\hline$\left(10^{6} \mathrm{RLU} \mathrm{s}^{-1}\right)$ & 1.69 & 3.28 & 2.05 & 3.11 & 0.23 & 1.98 & 0.10 \\
\hline $\mathrm{t}_{1 / 2}(\min )$ & 74.29 & 19.34 & 3.22 & 0.33 & 20.96 & 32.27 & 148 \\
\hline$\Sigma \mathrm{I}\left(10^{6} \mathrm{RLU}\right)$ & 84.98 & 80.85 & 5.61 & 11.57 & 6.29 & 62.97 & 6.04 \\
\hline $\mathrm{K}^{\prime} \mathrm{M}\left(10^{-6} \mathrm{M}\right)$ & 3.40 & 2.33 & 3.71 & 3.45 & 8.8 & 4.23 & 7.02 \\
\hline \multicolumn{8}{|l|}{$\mathrm{k}_{\text {cat }}$} \\
\hline$\left(10^{18} \mathrm{RLU} \mathrm{s}^{-1}\right)$ & 1.80 & 3.50 & 2.32 & 3.60 & 0.44 & 2.33 & 0.17 \\
\hline Molecules/RLU & 1775 & 4581 & 12067 & 4463 & 101169 & 1804 & 70020 \\
\hline $\mathrm{K}_{\mathrm{I}}\left(10^{-6} \mathrm{M}\right)$ & 104.94 & 115.21 & 140.55 & 101.64 & 22.48 & 84.02 & 35.42 \\
\hline $\mathrm{K}_{\mathrm{M}}\left(10^{-6} \mathrm{M}\right)$ & 2.22 & 3.02 & 5.90 & 3.88 & 6.80 & 3.30 & 2.94 \\
\hline $\mathrm{k}_{\mathrm{cat}}\left(\mathrm{mol}^{-\mathrm{s}^{-1}} \cdot \mathrm{mol}^{-1}\right)$ & 106 & 534 & 932 & 535 & 1500 & 140 & 362 \\
\hline $\mathrm{k}_{\text {inact }}\left(10^{-4} \mathrm{~s}-1\right)$ & 1.5 & 5.2 & 425 & 375 & 3.8 & 4.5 & 3.1 \\
\hline
\end{tabular}

Figure 3 is probably providing a better visual representation of these differences. In comparison with the central equidistant triangle representing three characteristics of furimazine (3): maximum intensity $\left(\mathrm{I}_{\max }\right)$, the sum of the signal $\left(\Sigma_{\mathrm{I}}\right)$, and half-life of the signal over two hours $\left(t_{1 / 2}\right)$, the values for the other substrates can vary widely. Accordingly, the next stage of our research will be to find out how specific structural features of the luciferins have an influence on these characteristics and more importantly, can such changes lead to even better luciferins. 

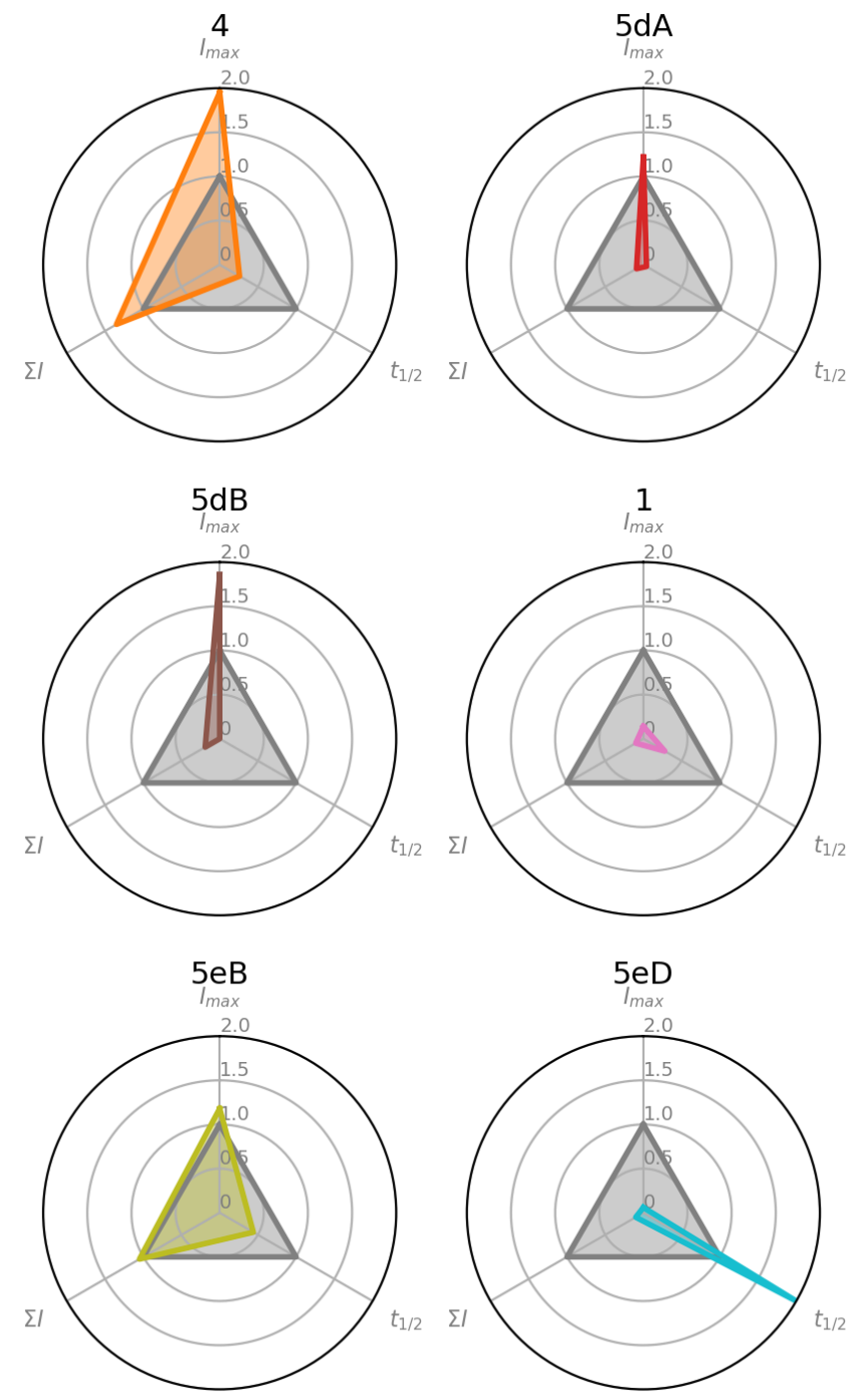

Figure 3. Depiction of the maxima of intensities $\left(I_{\max }\right)$, integrated signals $\left(\Sigma_{\mathrm{I}}\right)$, and half-time durations $\left(\mathrm{t}_{1 / 2}\right)$ for all the luciferins, relative to furimazine (3) represented in light grey.

\section{Conclusion}

In conclusion, the results of this work should herald more researches focusing/based on bioluminescent reporting systems using imidazo[1,2-a]pyrazine-3(7H)-one luciferins. Indeed, we describe here a simple mean to prepare these rather expensive luciferins in such amount that it should provide scientists with many more opportunities to design and use such reporting systems. The kinetic analyses of light emission presented here are providing rather unexpected insights for distinct applications. The glowing property of some substrates is appropriate for high throughput in vitro bioassays and long imaging dynamics in vivo or in cellulo, whereas the flashier profile of other is appropriate for high sensitivity acquisition systems requiring more light in a short time. Moreover, it appears that if the actual catalytic efficiency of nanoKaz/NanoLuc is high, as it is in the $10^{2}-10^{3} \mathrm{~mol} / \mathrm{s} \cdot \mathrm{mol}_{\varepsilon}$ range, the detection of emitted photons is remarkably modest: only one 
RLU for more than 1800 decarboxylated molecules at best. Also of note is the fast stochastic inactivation seen for some substrate in contrast with other which may reflect the existence of two distinct inactivation mechanisms which we are also trying to investigate. In any case, in view of all this, we believe that further luciferases mutagenesis and/or design of original luciferin analogues could lead to even more improved bioluminescence profiles.

\section{Acknowledgements}

This work was supported by the Agence Nationale de la Recherche (ANR), grant ANR-11CRNT-0004, in the context of the investment program 'GLOBAL CARE, an association of the Instituts Carnot 'Pasteur-Maladies Infectieuses', 'Curie-Cancer', 'Voir et Entendre', 'Institut du Cerveau et de la Moelle Epinière' and the 'Consortium pour l'Accélération de l'Innovation et de son Transfert dans le domaine du Lymphome' (CALYM). E.P.C. was supported by a fellowship from Global Care. This project also benefited from the ValoExpress funding of the Institut Pasteur. Prof. Christian Bréchot and Drs. Muriel Delepierre and Daniel Larzul are acknowledged for their interest and support. Finally, Victor Monnot's help is acknowledged for the syntheses of some compounds.

\section{References}

1 O. Shimomura, Bioluminescence: Chemical Principles And Methods Revised Edition, World Scientific, Singapore, 2012.

2 S. Martini and S. H. Haddock, Sci. Rep., 2017, 7, 45750.

3 S. Martini and S. H. Haddock, Sci. Rep., 2017, 7, 45750.

4 G. Thouand and R. Marks, Bioluminescence: Fundamentals and Applications in Biotechnology - Volume 1-3 (Advances in Biochemical Engineering/Biotechnology), 2014.

$5 \quad$ N. Boute, P. Lowe, S. Berger, M. Malissard, A. Robert and M. Tesar, Front. Pharmacol., 2016, $7,27$.

6 C. G. England, E. B. Ehlerding and W. Cai, Bioconjugate Chem., 2016, 27, 1175-1187.

7 Z. M. Kaskova, A. S. Tsarkova and I. V. Yampolsky, Chem. Soc. Rev., 2016, 45, 6048-6077.

8 T. Jiang, L. Du and M. Li, Photochem. Photobiol. Sci., 2016, 15, 466-480.

9 L. Mezzanotte, M. van 't Root, H. Karatas, E. A. Goun and C. W. G. M. Löwik, Trends Biotechnol., 2017, 35, 640-652.

10 C. M. Rathbun and J. A. Prescher, Biochemistry, 2017, 56, 5178-5184.

11 S. Inouye and O. Shimomura, Biochem. Biophys. Res. Commun., 1997, 233, 349-353.

12 A. M. Loening, A. M. Wu and S. S. Gambhir, Nat. Methods, 2007, 8, 641-643.

13 A. M. Loening, A. Dragulescu-Andrasi and S. S. Gambhir, Nat. Methods, 2010, 5, 5-6.

14 S. B. Kim, H. Suzuki, M. Sato and H. Tao, Anal. Chem., 2011, 83, 8732-8740.

15 M. H. Degeling, M. S. H. Bovenberg, G. K. Lewandrowski, M. C. de Gooijer, C. L. A. Vleggeert-Lankamp, M. Tannous, C. A. Maguire and B. A. Tannous, Anal. Chem., 2013, 85, 3006-3012.

16 W. C. Song, H. J. Sung, K. S. Park, J. W. Choi, J. Y. Cho and S. H. Um, Protein Expr. Purif., 2013, 91, 215220. 
17 H. Zhao, T. C. Doyle, R. J. Wong, Y. Cao, D. K. Stevenson, D. Piwnica-Worms and C. H. Contag, Mol. Imag., 2004, 3, 43-54.

18 S. B. Kim, R. Nishihara, D. Citterio and K. Suzuki, ACS Comb. Sci., 2017, 19, 594-599.

19 G. Giuliani, P. Molinari, G. Ferretti, A. Cappelli, M. Anzini, S. Vomero and T. Costa, Tetrahedron Lett., 2012, 53, 5114-5118.

20 M. P. Hall, J. Unch, B. F. Binkowski, M. P. Valley, B. L. Butler, M. G. Wood, P. Otto, K. Zimmerman, G. Vidugiris, T. Machleidt, M. B. Robers, H. A. Benink, C. T. Eggers, M. R. Slater, P. L. Meisenheimer, D. H. Klaubert, F. Fan, L. P. Encell and K. V. Wood, ACS Chem. Biol., 2012, 7, 1848-1857.

21 S. Inouye, J. Sato, Y. Sahara-Miura, S. Yoshida, H. Kurakata and T. Hosoya, Biochem. Biophys. Res. Commun., 2013, 437, 23-28.

22 S. Inouye, J. Sato, Y. Sahara-Miura, S. Yoshida and T. Hosoya, Biochem. Biophys. Res. Commun., 2014, 445, 157-162.

23 M.-L. Yuan, T.-Y. Jiang, L.-P. Du and M.-Y. Li, Chin. Chem. Lett., 2016, 27, 550-554.

24 A. Shakhmin, M. P. Hall, T. Machleidt, J. R. Walker, K. V. Wood and T. A. Kirkland, Org. Biomol. Chem., $2017,15,8559-8567$.

25 H.-W. Yeh, O. Karmach, A. Ji, D. Carter, M. M. Martins-Green and H. Ai, Nature Methods, 2017, 14, 971-974.

26 A. Shakhmin, M. P. Hall, J. R. Walker, T. Machleidt, B. F. Binkowski, K. V. Wood and T. A. Kirkland, Chem. Eur. J., 2016, 22, 10369-10375.

27 E. P. Coutant and Y. L. Janin, Chem. Eur. J., 2015, 21, 17158-17171.

28 F. McCapra and M. Roth, J. Chem. Soc., Chem. Commun., 1972, 894-895.

29 F. McCapra and M. J. Manning, J. Chem. Soc. Chem. Commun., 1973, 467-468.

30 I. Devillers, A. Arrault, G. Olive and J. Marchand-Brynaert, Tetrahedron Lett., 2002, 43, 3161-3164.

31 F. McCapra and Y. C. Chang, Chem. Commun., 1967, 1011-1012.

32 V. Hervin, E. P. Coutant, G. Gagnot and Y. L. Janin, Synthesis, 2017, 49, 4093-4110.

33 G. Gagnot, V. Hervin, E. P. Coutant, S. Desmons, R. Baatallah, V. Monnot and Y. L. Janin, Beilstein J. Org. Chem., 2018, 14, 2846-2852.

34 E. P. Coutant, V. Hervin, G. Gagnot, C. Ford, R. Baatallah and Y. L. Janin, Beilstein J. Org. Chem., 2018, 2853-2859.

35 T. Kudoh, S. Isoyama, S. Kagimoto, K. Kurihara and A. Sakakura, Tetrahedron Lett., 2016, 57, 4693-4696.

36 M. Knollmueller, L. Gaischin, M. Ferencic, M. Noe-Letschnig, U. Girreser, P. Gaertner, K. Mereiter and C. R. Noe, Monatsch. Chem., 1998, 129, 1025-1033.

37 M. Molteni, A. Volonterio and M. Zanda, Org. Lett., 2003, 5, 3887-3890.

38 G. P. Pollini, N. Baricordi, S. Benetti, C. De Risi and V. Zanirato, Tetrahedron Lett., 2005, 46, 3699-3701.

39 S. Bigotti, S. V. Meille, A. Volonterio and M. Zanda, J. Fluorine Chem., 2008, 129, 767-774.

40 Y. Chen, C. Zhong, J. L. Petersen, N. G. Akhmedov and X. Shi, Org. Lett., 2009, 11, 2333-2336.

41 S. Gabrielli, R. Ballini and A. Palmieri, Monatsch. Chem., 2013, 144, 509-514.

42 M. M. Robison, J. Am. Chem. Soc., 1958, 80, 5481-5483.

43 J. W. Corbett, M. R. Rauckhorst, F. Qian, R. L. Hoffmann, C. S. Knauer and L. W. Fitzgerald, Bioorg. Med. Chem. Lett., 2007, 17, 6250-6256.

44 B. Hoffman-Enger, C. Lescop, M. Soeberdt, A. Feurer, P. Weyermann, S. Nordhoff, A. Von Sprecher, H. Deppe and S. Bulat, EP2020405, 2009. 
45 F. Ma, X. Xie, L. Ding, J. Gao and Z. Zhang, Tetrahedron, 2011, 67, 9405-9410.

46 H. Hammoud, M. Schmitt, E. Blaise, F. Bihel and J. J. Bourguignon, J. Org. Chem., 2013, 78, 7930-7937.

47 D. Falcone, E. Osimboni and D. J. Guerin, Tetrahedron Lett., 2014, 55, 2646-2648.

48 H. Hu, M. Jiang, T. Jin, R. Niu, J. Wang, S. Yang, T. Yuan, C. Zhou, M. Wang and Z. Zhou, WO2014029726, 2014. 


\section{Supplementary information}

\section{Chemistry}

${ }^{1} \mathrm{H}$ NMR and ${ }^{13} \mathrm{C}$ NMR spectra were recorded on a Bruker Avance 400 spectrometer at $400 \mathrm{MHz}$ and $100 \mathrm{MHz}$, respectively. Shifts $(\delta)$ are given in ppm with respect to the TMS signal and crosscoupling constants $(J)$ are given in Hertz. Column chromatography were performed either on Merck silica gel $60(0.035-0.070 \mathrm{~mm})$ or neutral alumina containing $1.5 \%$ of added water using a solvent pump and an automated collecting system driven by a UV detector set to $254 \mathrm{~nm}$ unless required otherwise. Sample deposition was carried out by absorption of the mixture to be purified on a small amount of the solid phase followed by its deposition of the top of the column. The low resolution mass spectra were obtained on an Agilent 1100 series LC/MSD system using an atmospheric electrospray ionization system or an Agilent 1200 series LC/MSD system using an Agilent Jet-Stream atmospheric electrospray ionization system and the high resolution mass spectra (HRMS) were obtained using a Waters Micromass Q-Tof with an electrospray ion source. When specified, anhydrous solvents used were purchased. Unless stated otherwise, a purity of at least $95 \%$ was obtained for all the compounds by means of chromatography, recrystallization or distillation and this level of purity was established by TLC, LC/MS and NMR spectroscopy.

\section{Synthesis and separation of (3S,5R) and (3S,5S)-3-benzyl-5-phenylpiperazin-2-ones (15a).} First step: preparation of nitroethylamine 13a. Commercially available 2-nitrovinylbenzene (11a) $(3.78 \mathrm{~g}, 0.025 \mathrm{~mol})$ was added to a freshly extracted free base of L-phenylalanine ethyl ester (4.9 $\mathrm{g}, 0.025 \mathrm{~mol})$. The suspension was made homogeneous by the addition of a small amount of dichloromethane and the solvent was then removed under vacuum to give a thick oil. Upon standing at least 10 minutes, an ${ }^{1} \mathrm{H}$ NMR sample pointed out the occurrence of the 1,4 adducts. A complete conversion could never be observed even if the oil was left overnight at room temperature. However, a more than $95 \%$ conversion was routinely achieved if this oil was left for one hour in the present case. Second step: preparation of diamine 14a. The oil mentioned above was dispersed in a cold $\left(10^{\circ} \mathrm{C}\right)$ mixture of dioxane $(100 \mathrm{~mL})$ and $37 \%$ hydrochloric acid $(38.7$ $\mathrm{mL}, 0.33 \mathrm{~mol})$. Zinc dust $(7.45 \mathrm{~g}, 0.11 \mathrm{~mol},<10 \mu \mathrm{m})$ was added portion-wise in the course of 10 minutes while stirring rapidly. The suspension was then allowed to warm to room temperature 
and stirred for 2 hours. This was diluted in water, made basic with an excess of $22 \%$ ammonia and extracted with ethyl acetate. The organic layer was washed with a small amount of $22 \%$ ammonia, water, brine, dried over sodium carbonate and concentrated to dryness to give the crude aminoester 14a as an oil. Third step: preparation of compounds 15a. This oil was heated at $140{ }^{\circ} \mathrm{C}$ under argon for 3 hours. The resulting ethanol was removed under vacuum, the solid was dispersed in boiling cyclohexane and filtered to remove unreacted L-phenylalanine ester. At this stage, the resulting solid can be used directly in the next step or further purified by a chromatography over silica gel (dichloromethane / ethanol 96/4 to 95/5) to separate the two diasteroisomers of 15a as described below. Note: their structure attribution was easily performed by checking for the existence for the first diastereoisomer (or not, for the second diastereoisomer) of a nOe effect between their H-3 and H-5.<smiles>O=C1NC[C@@H](c2ccccc2)N[C@H]1Cc1ccccc1</smiles>

(3S,5R)-3-benzyl-5-phenylpiperazin-2-one (15a, first dia): Obtained as a white solid (2.05 g, 35\%). ${ }^{1} \mathrm{H} \mathrm{NMR}\left(\mathrm{CDCl}_{3}\right): 7.42-7.29(\mathrm{~m}, 9 \mathrm{H}), 7.23(\mathrm{~m}, 1 \mathrm{H}), 6.27(\mathrm{~s}, 1 \mathrm{H}), 4.06$ (dd, 1H, J = 9.7, $4.7 \mathrm{~Hz}), 3.84(\mathrm{dt}, 1 \mathrm{H}, J=10.1,3.4 \mathrm{~Hz}), 3.60(\mathrm{dd}, 1 \mathrm{H}, J=13.6,3.1 \mathrm{~Hz}), 3.32(\mathrm{~m}, 2 \mathrm{H}), 2.91$ (dd, $1 \mathrm{H}, J=13.6,10.1 \mathrm{~Hz}), 1.78(\mathrm{~s}, 1 \mathrm{H}) .{ }^{13} \mathrm{C} \mathrm{NMR}\left(\mathrm{CDCl}_{3}\right): 171.0,140.2,138.4,129.4,128.7,128.7$, 128.2, 126.8, 126.6, 60.9, 57.8, 50.0, 38.4. HRMS (m/z): $[\mathrm{M}+\mathrm{H}]^{+}$calcd for $\mathrm{C}_{17} \mathrm{H}_{19} \mathrm{~N}_{2} \mathrm{O}, 267.1497$, found: 267.1459 .

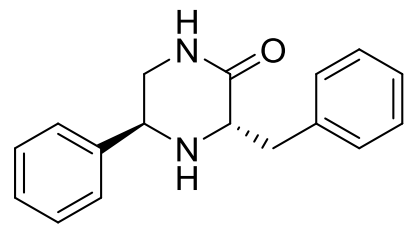

(3S,5S)-3-benzyl-5-phenylpiperazin-2-one (15a, second dia): Obtained as a white solid (1.29 g, 22\%). ${ }^{1} \mathrm{H} \mathrm{NMR}\left(\mathrm{CDCl}_{3}\right): 7.46-7.18(\mathrm{~m}, 10 \mathrm{H}), 6.44(\mathrm{~s}, 1 \mathrm{H}), 4.27(\mathrm{dd}, 1 \mathrm{H}, J=9.6,4.0 \mathrm{~Hz}), 3.89$ $(\mathrm{dd}, 1 \mathrm{H}, J=10.7,3.6 \mathrm{~Hz}), 3.50(\mathrm{~m}, 1 \mathrm{H}), 3.41(\mathrm{dt}, 1 \mathrm{H}, J=11.5,4.0 \mathrm{~Hz}), 3.32(\mathrm{dd}, 1 \mathrm{H}, J=13.8$, 
$3.6 \mathrm{~Hz}), 3.18(\mathrm{dd}, 1 \mathrm{H}, J=13.8,10.7 \mathrm{~Hz}), 1.79(\mathrm{~s}, 1 \mathrm{H}) .{ }^{13} \mathrm{C} \mathrm{NMR}\left(\mathrm{CDCl}_{3}\right): 171.8,139.8,138.0$, $129.3,128.9,128.8,128.2,126.9,126.8,59.4,51.7,49.3,37.8$. HRMS $(m / z):[\mathrm{M}+\mathrm{H}]^{+}$calcd for $\mathrm{C}_{17} \mathrm{H}_{19} \mathrm{~N}_{2} \mathrm{O}, 267.1497$, found: 267.1435.

\section{Synthesis and separation of (3S,5R) and (3S,5S)-3-benzyl-5-(4-(benzyloxy)phenyl)piperazin-}

2-one (15b). First step: preparation of nitroethylamine 13b. The 1-(benzyloxy)-4-(2nitrovinyl)benzene ${ }^{1}$ (11b) (3.54 g, $0.013 \mathrm{~mol}$ ) was added to a freshly extracted free base of Lphenylalanine ethyl ester $(2.68 \mathrm{~g}, 0.013 \mathrm{~mol})$. The suspension was made homogeneous by the addition of a small amount of dichloromethane $(30 \mathrm{~mL})$ and the solvent was then removed under vacuum to give a thick oil. This was left standing overnight at room temperature to ensure a most complete conversion. Second step: preparation of diamine 14b. The oil mentioned above was dispersed in a cold $\left(10^{\circ} \mathrm{C}\right)$ mixture of dioxane $(50 \mathrm{~mL})$ and $37 \%$ hydrochloric acid $(20 \mathrm{~mL}, 0.16$ mol). Zinc dust (3.65 g, $0.055 \mathrm{~mol})$ was added portion-wise in the course of 10 minutes while stirring rapidly. The suspension was then allowed to warm to room temperature and stirred for 2 hours. This was diluted in water, made basic with an excess of $22 \%$ ammonia and extracted with ethyl acetate. The organic layer was washed with a small amount of $22 \%$ ammonia, water and brine, dried over sodium carbonate and concentrated to dryness to give the crude aminoester $\mathbf{1 4 b}$ as an oil. Third step: preparation of compounds $\mathbf{1 5 b}$. This oil was heated at $140{ }^{\circ} \mathrm{C}$ under argon for 3 hours. The resulting ethanol was removed under vacuum and the diasteroisomers of compound $15 \mathrm{~b}$ could be separated as described below. On a larger scale (i.e.: from $12.19 \mathrm{~g}$ of compound 11b), the crude aminoester $14 \mathrm{~b}$ was heated at $190{ }^{\circ} \mathrm{C}$ in an oil bath under high vacuum for how long as it took (20 minutes) to remove the unreacted phenylalanine ethyl ester which plagued any purification as well as the aromatization step when using sulfur. Accordingly, this oil could be used in the next step (with sulfur) without further purification. Alternatively, also on a large scale (22.25 g of compound $\mathbf{1 1 b}$ ), the crude compound $\mathbf{1 5 b}$ obtained was then oxidized directly into the $\mathrm{N}$-oxide $\mathbf{1 7} \mathbf{b}$ as described below. 




(3S,5R)-3-benzyl-5-(4-(benzyloxy)phenyl)piperazin-2-one (15b, first dia): This isomer was obtained using the first procedure described above as a white powder $(0.92 \mathrm{~g}, 17 \%)$ after two chromatography over silica gel (dichloromethane - ethanol 95/5 to 92/8) and (cyclohexane - ethyl acetate $1 / 2)$ and a recrystallization in cyclohexane. ${ }^{1} \mathrm{H}$ NMR $\left(\mathrm{CDCl}_{3}\right): 7.45-7.21(\mathrm{~m}, 12 \mathrm{H}), 6.94$ (m, 2H), 6.47 (s (br), 1H), $5.06(\mathrm{~s}, 2 \mathrm{H}), 4.00(\mathrm{dd}, 1 \mathrm{H}, J=4.3,10.1 \mathrm{~Hz}), 3.83$ (dd, 1H, $J=3.0$, $10.1 \mathrm{~Hz}), 3.59$ (dd, 1H, $J=3.0,13.6 \mathrm{~Hz}), 3.32(\mathrm{~m}, 2 \mathrm{H}), 2.90(\mathrm{dd}, 1 \mathrm{H}, J=10.1,13.6 \mathrm{~Hz}), 1.73(\mathrm{~s}$ (br), $1 \mathrm{H}) .{ }^{13} \mathrm{C} \mathrm{NMR}\left(\mathrm{CDCl}_{3}\right): 171.1,158.7,138.4,136.9,132.5,129.4,128.7,128.6,128.0$, 127.9, 127.4, 126.6, 115.0, 70.1, 60.9, 57.2, 50.0, 38.5. HRMS $(\mathrm{m} / \mathrm{z}):[\mathrm{M}+\mathrm{H}]^{+}$calcd for $\mathrm{C}_{25} \mathrm{H}_{25} \mathrm{~N}_{2} \mathrm{O}_{3}: 373.1916$, found: 373.1932 .

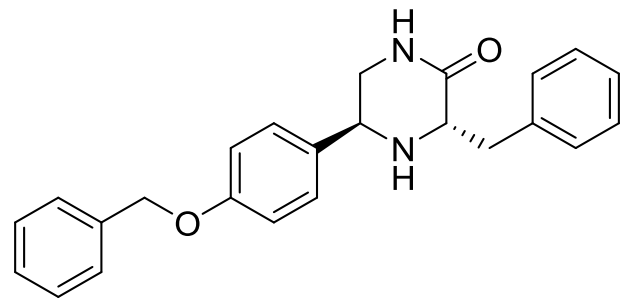

(3S,5S)-3-benzyl-5-(4-(benzyloxy)phenyl)piperazin-2-one (15b, second dia): This isomer was obtained using the first procedure described above as a white powder $(0.59 \mathrm{~g}, 11 \%)$ after two chromatography over silica gel (dichloromethane - ethanol 95/5 to 92/8) and (ethyl acetate ethanol 1/0 to 99/1). ${ }^{1} \mathrm{H}$ NMR $\left(\mathrm{CDCl}_{3}\right)$ : 7.45 - 7.23 (m, 12H), 6.96 (m, 2H), 6.67 (s (br), 1H), $5.07(\mathrm{~s}, 2 \mathrm{H}), 4.21(\mathrm{dd}, 1 \mathrm{H}, J=4.0,9.6 \mathrm{~Hz}), 3.85(\mathrm{dd}, 1 \mathrm{H}, J=3.5,10.7 \mathrm{~Hz}), 3.40(\mathrm{~m}, 2 \mathrm{H}), 3.31$ $(\mathrm{dd}, 1 \mathrm{H}, J=3.5,13.8 \mathrm{~Hz}), 3.18(\mathrm{dd}, 1 \mathrm{H}, J=10.7,13.7 \mathrm{~Hz}), 1.76(\mathrm{~s}(\mathrm{br}), 1 \mathrm{H}) .{ }^{13} \mathrm{C} \mathrm{NMR}\left(\mathrm{CDCl}_{3}\right)$ : 171.9, 158.7, 138.0, 136.9, 132.2, 129.3, 128.9, 128.6, 128.1, 128.0, 127.4, 126.8, 115.0, 70.1, 59.4, 51.1, 49.3, 37.6. HRMS (m/z): $[\mathrm{M}+\mathrm{H}]^{+}$calcd for $\mathrm{C}_{25} \mathrm{H}_{25} \mathrm{~N}_{2} \mathrm{O}_{3}$ : 373.1916, found: 373.1907 . 


\section{Synthesis and separation of (3S,5R) and (3S,5S)-3-benzyl-5-(3-(benzyloxy)phenyl)piperazin-}

2-one (15c). First step: preparation of nitroethylamine 13c. The 1-(benzyloxy)-3-(2nitrovinyl)benzene $(11 \mathrm{c})^{2}(10.77 \mathrm{~g}, 0.042 \mathrm{~mol})$, L-phenylalanine ethyl ester hydrochloride (9.69 $\mathrm{g}, 0.042 \mathrm{~mol})$ and triethylamine $(4.48 \mathrm{~g}, 0.044 \mathrm{~mol})$ were stirred in dichloromethane $(50 \mathrm{~mL})$ for 10 minutes and the solvent was removed under vacuum to give a thick oil. This was left standing overnight at room temperature to ensure a most complete conversion. Second step: preparation of diamine 14c. The oil mentioned above was dispersed in a cold $\left(10^{\circ} \mathrm{C}\right)$ mixture of dioxane $(100$ $\mathrm{mL})$ and 37\% hydrochloric acid (41 mL, $0.506 \mathrm{~mol})$. Zinc dust (10.9 g, $0.168 \mathrm{~mol})$ was added portion-wise in the course of 10 minutes while stirring rapidly. The suspension was then allowed to warm to room temperature and stirred for 2 hours. This was diluted in water, made basic with an excess of $22 \%$ ammonia and extracted with ethyl acetate. The organic layer was washed with a small amount of $22 \%$ ammonia, water and brine, dried over sodium carbonate and concentrated to dryness to give the crude aminoester $14 \mathbf{c}$ as an oil. Third step: preparation of compounds $\mathbf{1 5 c}$. This oil was heated at $140{ }^{\circ} \mathrm{C}$ under argon for 3 hours. The resulting ethanol was removed under vacuum and the residue extracted with boiling cyclohexane, the extract left to crystallize to yield (in two crops) compound $\mathbf{1 5 c}$ as a mixture of the two diasteroisomers (4.92 $\mathrm{g}, 31 \%)$. The insoluble material and the filtrates were concentrated to dryness and additional amount of the two (separated) diasteroisomers (1.64 $\mathrm{g}$ and $1.77 \mathrm{~g}, 21 \%$ in total) were obtained from this residue as described below.

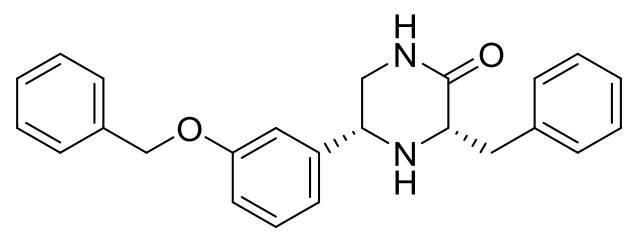

(3S,5R)-3-benzyl-5-(3-(benzyloxy)phenyl)piperazin-2-one (15c, first dia): This isomer was obtained from the recrystallization residue described above as a white powder (1.64 g), still containing $3 \%$ of an unidentified material, after two chromatography over silica gel (dichloromethane - ethanol 97/3 to 96/4), (cyclohexane - ethyl acetate 2/3) and a recrystallization in cyclohexane. ${ }^{1} \mathrm{H}$ NMR (DMSO- $\left.d_{6}\right): 7.75(\mathrm{~d}(\mathrm{br}), 1 \mathrm{H}, J=4.0 \mathrm{~Hz}), 7.46-7.15(\mathrm{~m}, 11 \mathrm{H}), 7.05(\mathrm{~m}$, 1H), $6.95(\mathrm{~m}, 1 \mathrm{H}), 6.90(\mathrm{~m}, 1 \mathrm{H}), 5.08(\mathrm{~s}, 2 \mathrm{H}), 3.97(\mathrm{~m}, 1 \mathrm{H}), 3.67$ (m, 1H), 3.27 (dd, 1H, $J=13.8$, $3.63 \mathrm{~Hz}), 3.20$ (dt, 1H, $J=11.3,4 \mathrm{~Hz}), 3.03(\mathrm{t}, 1 \mathrm{H}, J=10.9 \mathrm{~Hz}), 2.82(\mathrm{dd}, 1 \mathrm{H}, J=13.9,8.6 \mathrm{~Hz})$, 
$2.31(\mathrm{~m}, 1 \mathrm{H}) .{ }^{13} \mathrm{C}$ NMR (DMSO- $\left.d_{6}\right): 170.2,158.8,143.4,139.7,137.5,129.9,129.8,128.9$, 128.5, 128.3, 128.1, 126.4, 119.6, 114.1, 113.8, 69.6, 60.3, 56.7, 49.2, 38.1. HRMS $(\mathrm{m} / \mathrm{z})$ : $[\mathrm{M}+\mathrm{H}]^{+}$calcd for $\mathrm{C}_{24} \mathrm{H}_{25} \mathrm{~N}_{2} \mathrm{O}_{2}: 373.1916$, found: 373.1919 .

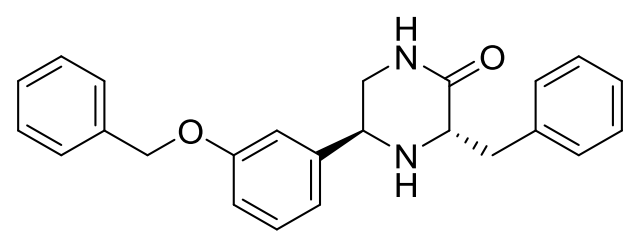

(3S,5S)-3-benzyl-5-(3-(benzyloxy)phenyl)piperazin-2-one (15c, second dia): This isomer was obtained from the recrystallization residue described above as a white powder $(1.77 \mathrm{~g})$ after a chromatography over silica gel (dichloromethane - ethanol 97/3 to 96/4) and a dispersion in boiling cyclohexane. ${ }^{1} \mathrm{H}$ NMR (DMSO- $\left.d_{6}\right): 7.81(\mathrm{~d}(\mathrm{br}), 1 \mathrm{H}, J=3.0 \mathrm{~Hz}), 7.45-7.31(\mathrm{~m}, 5 \mathrm{H}), 7.28$ - $7.16(\mathrm{~m}, 6 \mathrm{H}), 7.04(\mathrm{~m}, 1 \mathrm{H}), 6.91(\mathrm{~m}, 2 \mathrm{H}), 5.05(\mathrm{~s}, 2 \mathrm{H}), 4.06(\mathrm{~m}, 1 \mathrm{H}), 3.52(\mathrm{~m}, 1 \mathrm{H}), 3.29(\mathrm{~m}$, $1 \mathrm{H}), 3.21(\mathrm{~m}, 1 \mathrm{H}), 3.03(\mathrm{~m}, 2 \mathrm{H}), 2.45(\mathrm{~s}(\mathrm{br}), 1 \mathrm{H}) .{ }^{13} \mathrm{C}$ NMR (DMSO- $\left.d_{6}\right): 171.2,158.9,143.3$, 139.9, 137.6, 129.8, 129.7, 128.9, 128.6, 128.3, 128.1, 126.5, 119.6, 114.0, 113.8, 69.6, 58.7, 51.2, 48.3, 37.8. HRMS ( $/ \mathrm{z} / \mathrm{z}):[\mathrm{M}+\mathrm{H}]^{+}$calcd for $\mathrm{C}_{24} \mathrm{H}_{25} \mathrm{~N}_{2} \mathrm{O}_{2}: 373.1916$, found: 373. 1926.

General procedure for the synthesis of compounds 16a-c using sulfur. The considered piperazin-2-one $(0.011 \mathrm{~mol})$ and sulfur $(0.72 \mathrm{~g}, 0.0225 \mathrm{~mol})$ were heated to reflux in 1,3dichlorobenzene $(40 \mathrm{~mL})$ for 10 hours. This was concentrated to dryness and the residue purified as described below. On a larger scale, the residue was routinely taken up directly in the next step to obtain the chloropyrazines $\mathbf{9}$ as described.<smiles>Oc1ncc(-c2ccccc2)nc1Cc1ccccc1</smiles>

3-Benzyl-5-phenylpyrazin-2-ol (16a): This compound was obtained as a white powder (2.28 g, $73 \%$ ) after a chromatography over silica gel (dichloromethane - ethanol 98/2 to 97/3). ${ }^{1} \mathrm{H}$ NMR 
(DMSO-d $\left.)_{6}\right) 12.41(\mathrm{~s}, 1 \mathrm{H}), 7.85(\mathrm{~m}, 3 \mathrm{H}), 7.40(\mathrm{~m}, 4 \mathrm{H}), 7.30(\mathrm{~m}, 3 \mathrm{H}), 7.20(\mathrm{~m}, 1 \mathrm{H}), 4.07(\mathrm{~s}, 2 \mathrm{H})$. ${ }^{13} \mathrm{C}$ NMR (DMSO- $d_{6}$ ): 157.4, 155.4, 138.4, 136.4, 131.4, 129.6, 129.1, 128.7, 127.7, 126.7, 124.9, 122.9, 39.3. HRMS $(m / z):[\mathrm{M}+\mathrm{H}]^{+}$calcd for $\mathrm{C}_{17} \mathrm{H}_{15} \mathrm{~N}_{2} \mathrm{O}$ : 263.1184, found, 263.1118 .

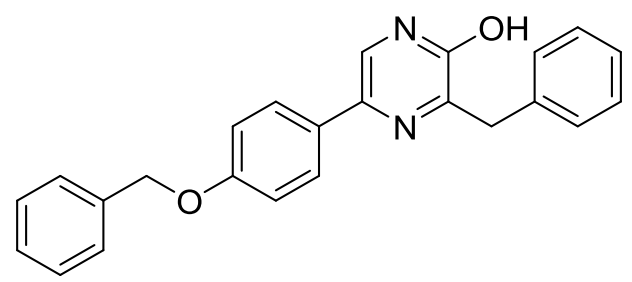

3-Benzyl-5-(4-(benzyloxy)phenyl)pyrazin-2-ol (16b): This compound was obtained as a powder (0.8 g, 62\%) after a chromatography over silica gel (dichloromethane - ethanol 98/2). ${ }^{1} \mathrm{H}$ NMR (DMSO- $\left.d_{6}\right) 12.31(\mathrm{~s}, 1 \mathrm{H}), 7.78(\mathrm{~m}, 2 \mathrm{H}), 7.40(\mathrm{~m}, 4 \mathrm{H}), 7.37(\mathrm{~m}, 9 \mathrm{H}), 7.19(\mathrm{~m}, 1 \mathrm{H}), 7.03(\mathrm{~m}, 2 \mathrm{H})$, 5.13 (s, 2H), 4.06 (s, 2H). ${ }^{13} \mathrm{C}$ NMR (DMSO- $d_{6}$ ): $157.8,156.5,154.8,137.9,137.0,131.2,129.0$, $128.8,128.4,128.2,127.7,127.6,126.1,125.8,121.5,114.9,69.2,38.8$. HRMS $(m / z):[\mathrm{M}+\mathrm{H}]^{+}$ calcd for $\mathrm{C}_{24} \mathrm{H}_{22} \mathrm{~N}_{2} \mathrm{O}_{2}: 369.1603$, found, 369.1603 .<smiles>Oc1ncc(-c2cccc(OCc3ccccc3)c2)nc1Cc1ccccc1</smiles>

3-Benzyl-5-(3-(benzyloxy)phenyl)pyrazin-2-ol (16c): This compound was obtained as beige solid $(1.41 \mathrm{~g}, 54 \%)$ as described above but using boiling decaline $(30 \mathrm{~mL})$ instead of 1,3dichlorobenzene after a chromatography over silica gel (cyclohexane - ethyl acetate $2 / 1$ to $1 / 1$ ). ${ }^{1} \mathrm{H}$ NMR (DMSO-d $\left.d_{6}\right) 12.42$ (s (br), 1H), 7.92 (s, 1H), 7.50-7.27 (m, 12H), 7.20 (m, 1H), 6.94 (m, 1H), 5.13 (s, 2H), 4.07 (s, 2H). ${ }^{13} \mathrm{C}$ NMR (DMSO- $\left.d_{6}\right): 159.2,157.3,155.5,138.3,137.9,137.6$, 131.0, 130.2, 129.7, 128.9, 128.7, 128.3, 128.1, 126.6, 123.1, 117.5, 114.2, 111.3, 69.7, 39.3. HRMS $(m / z):[\mathrm{M}+\mathrm{H}]^{+}$calcd for $\mathrm{C}_{24} \mathrm{H}_{22} \mathrm{~N}_{2} \mathrm{O}_{2}: 369.1603$, found, 369. 1609.

\section{General procedure for the synthesis of the N-oxide 17a-b:}


<smiles>O=C1NCC(c2ccccc2)[N+]([O-])=C1Cc1ccccc1</smiles>

6-Benzyl-5-oxo-2-phenyl-2,3,4,5-tetrahydropyrazine $\quad$ 1-oxide $\quad(\mathbf{1 7 a}): \quad$ To 3 -benzyl-5phenylpiperazin-2-one $(0.44 \mathrm{~g}, 1.65 \mathrm{mmol})$ dissolved in acetic acid $(5 \mathrm{~mL})$ was added a $36 \%$ solution of peracetic acid in acetic acid $(0.77 \mathrm{~g}, 3.63 \mathrm{mmol})$. This was stirred overnight, diluted in ethyl acetate, washed with water, brine, dried over molecular sieve and concentrated to dryness. The residue was purified by a chromatography over silica gel (cyclohexane - ethyl acetate 1/1 to $1 / 2)$ to yield the N-oxide $(0.26 \mathrm{~g}, 56 \%)$ as a white powder. Nota, COSY correlations firmly established the structures of this compound. ${ }^{1} \mathrm{H} \mathrm{NMR}\left(\mathrm{CDCl}_{3}\right): 7.43(\mathrm{~m}, 2 \mathrm{H}), 7.35-7.20(\mathrm{~m}, 6 \mathrm{H})$, $7.15(\mathrm{~m}, 2 \mathrm{H}), 6.84$ (s (br), 1H), 5.12 (t, 1H, J = 4.4 Hz), 4.13 (s, 2H), 4.00 (dd, 1H, J = 4.4, 13.3 $\mathrm{Hz}), 3.63(\mathrm{dt}, 1 \mathrm{H}, J=4.4,13.3 \mathrm{~Hz}) .{ }^{13} \mathrm{C} \mathrm{NMR}\left(\mathrm{CDCl}_{3}\right): 161.2,141.7,136.0,134.2,129.6,129.1$, 129.0, 128.4, 126.7, 126.6, 71.8, 43.1, 30.2. HRMS $(m / z):[\mathrm{M}+\mathrm{H}]^{+}$calcd for $\mathrm{C}_{17} \mathrm{H}_{17} \mathrm{~N}_{2} \mathrm{O}_{2}$ : 281.1190, found, 281.1234.<smiles>O=C1NCC(c2ccc(OCc3ccccc3)cc2)[N+]([O-])=C1Cc1ccccc1</smiles>

6-Benzyl-2-(4-(benzyloxy)phenyl)-5-oxo-2,3,4,5-tetrahydropyrazine 1-oxide (17b): The crude piperazin-2-one 16b obtained from compound $\mathbf{1 1 b}(0.0871 \mathrm{~mol})$ as described above was dissolved in ethyl acetate $(600 \mathrm{~mL}), 35 \%$ peracetic acid in acetic acid $(33.8 \mathrm{~mL}, 0.174 \mathrm{~mol})$ was added and this was stirred for 24 hours. The precipitate was filtered, washed with ethyl acetate and dried to yield compound $\mathbf{1 7 b}(5.40 \mathrm{~g}, 16 \%$ from nitrostyrene $\mathbf{1 1 b})$. The filtrate was washed with water, brine, dried over magnesium sulfate, concentrated to dryness and the residue purified by chromatography over silica gel (cyclohexane - ethyl acetate $1 / 1$ to $1 / 2$ ) to yield more of compound 17b (7.31 g, 21\% from nitrostyrene 11b). ${ }^{1} \mathrm{H}$ NMR (DMSO-d6) 8.31 (d (br), 1H, $J=$ 
$3.8 \mathrm{~Hz}), 7.44-7.17(\mathrm{~m}, 10 \mathrm{H}), 7.14(\mathrm{~m}, 2 \mathrm{H}), 6.97(\mathrm{~m}, 2 \mathrm{H}), 5.17(\mathrm{~m}, 1 \mathrm{H}), 5.10(\mathrm{~s}, 2 \mathrm{H}), 3.94(\mathrm{~m}$, $3 \mathrm{H}), 3.53\left(\mathrm{dt}, 1 \mathrm{H}, J=4.5,14.0 \mathrm{~Hz}\right.$ ). ${ }^{13} \mathrm{C}$ NMR (DMSO- $d_{6}$ ): 160.7, 158.8, 140.7, 137.4, 137.2, 129.3, 128.9, 128.6, 128.5, 128.3, 128.1, 128.0, 126.7, 71.0, 69.7, 42.6, 30.2 (one signal missing). HRMS $(\mathrm{m} / z)$ : $[\mathrm{M}+\mathrm{H}]^{+}$calcd for $\mathrm{C}_{24} \mathrm{H}_{23} \mathrm{~N}_{2} \mathrm{O}_{3}: 387.1709$, found, 387.1714 .

Procedure for the synthesis of compounds 16a via a thermal dehydration of the $\mathbf{N}$-oxide 17a. In a microwave-adapted vial, a crude batch of 6-benzyl-5-oxo-2-phenyl-2,3,4,5tetrahydropyrazine 1-oxide $(0.41 \mathrm{~g}, 1.46 \mathrm{mmol})$ obtained as described above was dissolved in chlorobenzene $(5 \mathrm{~mL})$. This was sealed and heated in a microwave oven at $190{ }^{\circ} \mathrm{C}$ for two hours. The solvent was removed in vacuum and the residue purified by a chromatography over silica gel (cyclohexane - ethyl acetate 3/2) to give 3-benzyl-5-phenylpyrazin-2-ol 16a $(0.20 \mathrm{~g}, 52 \%$ from 3-benzyl-5-phenylpiperazin-2-one 15a) with analytical data identical with the one described above.

Procedure for the synthesis of compounds 16a-b via a sodium hydroxide - based rearrangement of the $\mathbf{N}$-oxides $17 \mathbf{a}-\mathbf{b}$, representative procedure. The $\mathrm{N}$-oxide $17 \mathbf{b}(7.31 \mathrm{~g}$, $0.0189 \mathrm{~mol})$ and sodium hydroxide $(2.26 \mathrm{~g}, 0.0567 \mathrm{~mol})$ were heated to reflux in ethanol $(90 \mathrm{~mL})$ for one hour. This was diluted in water, made acid with hydrochloric acid, the precipitate was filtered, washed with water and dried under vacuum at $60{ }^{\circ} \mathrm{C}$ to yield compound $\mathbf{1 6 b}(6.66 \mathrm{~g}$, $95 \%)$ as described above. Note: from a sample of compound $17 \mathbf{a}(0.11 \mathrm{~g}, 0.39 \mathrm{mmol})$, the same protocol gave compound $16 \mathbf{a}(0.09 \mathrm{~g}, 87 \%)$ as described above.

General procedure for the synthesis of compounds 9a-c: under a calcium-protected atmosphere, the considered 2-hydroxypyrazine $(0.02 \mathrm{~mol})$ was dispersed in phenylphosphonic dichloride $(10 \mathrm{~mL})$ and the suspension was heated at $100{ }^{\circ} \mathrm{C}$ for the indicated time. The resulting solution was diluted in ethyl acetate and poured onto an excess of crushed ice and stirred for 15 min. This was made basic with $22 \%$ ammonia and extracted with ethyl acetate. The organic layer was washed with water, brine, dried over magnesium sulfate and concentrated to dryness. The resulting residues were purified as described below. 
<smiles>Clc1ncc(-c2ccccc2)nc1Cc1ccccc1</smiles>

3-benzyl-2-chloro-5-phenylpyrazine (9a): Obtained as a yellowish solid (1.60 g, 82\%) after a chromatography over silica gel (cyclohexane-dichloromethane 3:2). Alernatively, this compound was obtained in $36 \%$ yield under the same reaction conditions but using the N-oxide 17a. Note: From the crude mixture of compound 15a obtained by a simple dispertion in boiling cyclohexane as described above and undertaking the next two synthetic steps (sulfur-based aromatization and chlorodehydroxylation) whithout any chromatography, batches of the pure compound 9a (20.04 g, 62\% from 11a) were routinely obtained after a single chromatography over silica gel (dichloromethane-ethanol 97/3 to 96.5/3.5). ${ }^{1} \mathrm{H}$ NMR $\left(\mathrm{CDCl}_{3}\right): 8.68$ (s, 1H), 8.04 (m, 2H), 7.55 $(\mathrm{m}, 3 \mathrm{H}), 7.42(\mathrm{~m}, 2 \mathrm{H}), 7.35(\mathrm{~m}, 2 \mathrm{H}), 7.28(\mathrm{~m}, 1 \mathrm{H}), 4.41(\mathrm{~s}, 2 \mathrm{H}) .{ }^{13} \mathrm{C} \mathrm{NMR}\left(\mathrm{CDCl}_{3}\right)$ : 153.6, 150.4, 146.9, 138.6, 137.1, 135.4, 130.0, 129.2, 129.1, 128.5, 126.9, 126.8, 41.2. HRMS $(\mathrm{m} / \mathrm{z}):[\mathrm{M}+\mathrm{H}]^{+}$ calcd for $\mathrm{C}_{17} \mathrm{H}_{14} \mathrm{ClN}_{2}, 281.0846$, found, 281.0730.

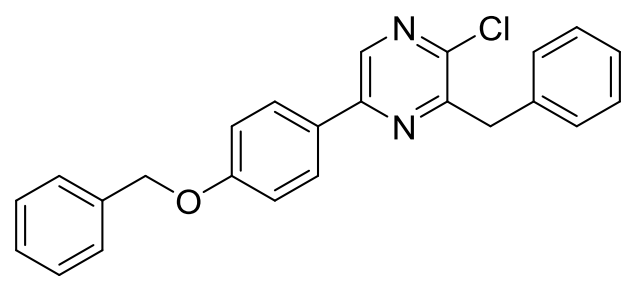

3-Benzyl-5-(4-(benzyloxy)phenyl)-2-chloropyrazine (9b): Obtained as a yellow solid (5.66 g, $62 \%$ ) after heating for 18 hours and a chromatography over silica gel (cyclohexanedichloromethane 1/1). ${ }^{1} \mathrm{H}$ NMR $\left(\mathrm{CDCl}_{3}\right)$ : 8.61 (s, 1H), $8.0(\mathrm{~m}, 2 \mathrm{H}), 7.47-7.20(\mathrm{~m}, 10 \mathrm{H}), 7.11$ (m, 2H), 5.17 (s, 2H), 4.38 (s, 2H). ${ }^{13} \mathrm{C}$ NMR $\left(\mathrm{CDCl}_{3}\right): 161.5,153.3,150.1,145.9$, 138.0, 137.2, 136.6, 129.2, 128.7, 128.5, 128.3, 128.1, 127.9, 127.4, 126.7, 115.4, 70.1, 41.2 (one signal missing). HRMS ( $m / z):[\mathrm{M}+\mathrm{H}]^{+}$calcd for $\mathrm{C}_{24} \mathrm{H}_{20} \mathrm{ClN}_{2} \mathrm{O}, 387.1264$, found, 387.1266. 


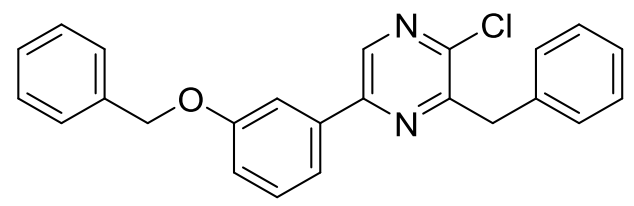

3-Benzyl-5-(3-(benzyloxy)phenyl)-2-chloropyrazine (9c): Obtained as a slowly solidifying oil $(0.77 \mathrm{~g}, 61 \%)$ after heating for 18 hours and a chromatography over silica gel (cyclohexane-ethyl acetate 97/3). ${ }^{1} \mathrm{H}$ NMR $\left(\mathrm{CDCl}_{3}\right): 8.65$ (s, 1H), 7.69 (m, 1H), 7.60 (m, 1H), 7.50 (m, 2H), 7.45$7.32(\mathrm{~m}, 8 \mathrm{H}), 7.27(\mathrm{~m}, 1 \mathrm{H}), 7.11(\mathrm{~m}, 1 \mathrm{H}), 5.17(\mathrm{~s}, 2 \mathrm{H}), 4.40(\mathrm{~s}, 2 \mathrm{H}) .{ }^{13} \mathrm{C} \mathrm{NMR}\left(\mathrm{CDCl}_{3}\right):$ 159.4, 153.6, 150.0, 147.0, 138.6, 137.1, 136.8, 136.7, 130.1, 129.3, 128.7, 128.5, 128.1, 127.6, 126.8, 119.4, 116.7, 113.4, 70.2, 41.2. HRMS $(\mathrm{m} / \mathrm{z})$ : $[\mathrm{M}+\mathrm{H}]^{+}$calcd for $\mathrm{C}_{24} \mathrm{H}_{20} \mathrm{ClN}_{2} \mathrm{O}, 387.1264$, found, 387.1262 .

General procedure for the $\mathbf{N}$-arylation of chloropyrazines $9 a-c$ by $\boldsymbol{\alpha}$-aminoesters. In a $20 \mathrm{~mL}$ sealable vial, the considered 2-halogenopyrazine $(1 \mathrm{mmol})$, the considered $\alpha$-aminoesters ${ }^{3,4}$ (1.1 $\mathrm{mmol}$, either as a free base or as a hydrochloride salt), cesium carbonate $(1.04 \mathrm{~g}, 3.2 \mathrm{mmol})$, palladium acetate $(0.011 \mathrm{~g}, 0.05 \mathrm{mmol}$,) and 1,1'-binaphthalene-2,2'-diyl)bis(diphenylphosphine) (BINAP) $(0.047 \mathrm{~g}, 0.075 \mathrm{mmol})$ were weighted. The air was replaced by argon and dry acetonitrile $(4 \mathrm{~mL})$ was injected. This was heated under an inert atmosphere (a balloon inflated with argon) at $60{ }^{\circ} \mathrm{C}$ for 12 hours using an oil bath along with fast stirring to break up any clumps of cesium hydrogen carbonate forming. The resulting dark red or black suspension was dispersed in dichloromethane, this was filtered, rinsed with dichloromethane and the filtrate was concentrated to dryness prior further purifications as described below. Note: on larger scale, a flask fitted with a rubber septum and a balloon inflated with argon worked as fine.<smiles>CCOC(=O)C(Cc1ccccc1)Nc1ncc(-c2ccccc2)nc1Cc1ccccc1</smiles> 
Ethyl (3-benzyl-5-phenylpyrazin-2-yl)phenylalaninate (18aA): Obtained as an oil (1.07 g, 69\%) after a chromatography over silica gel (dichloromethane). ${ }^{1} \mathrm{H}$ NMR $\left(\mathrm{CDCl}_{3}\right): 8.43(\mathrm{~s}, 1 \mathrm{H}), 7.96$ $(\mathrm{m}, 2 \mathrm{H}), 7.49(\mathrm{~m}, 1 \mathrm{H}), 7.37(\mathrm{~m}, 1 \mathrm{H}), 7.33-7.20(\mathrm{~m}, 8 \mathrm{H}), 7.90(\mathrm{~m}, 2 \mathrm{H}), 4.97(\mathrm{~m}, 2 \mathrm{H}), 4.14(\mathrm{~s}$, 2H), $4.13(\mathrm{q}, 2 \mathrm{H}, J=7.1 \mathrm{~Hz}), 3.18(\mathrm{dd}, 1 \mathrm{H}, J=13.8,5.4 \mathrm{~Hz}), 3.09$ (dd, 1H, $J=13.8,5.9 \mathrm{~Hz})$, $1.20(\mathrm{t}, 3 \mathrm{H}, J=7.1 \mathrm{~Hz}) .{ }^{13} \mathrm{C} \mathrm{NMR}\left(\mathrm{CDCl}_{3}\right): 172.4,150.4,141.2,141.1,137.5,136.9,136.5$, 136.3, 129.3, 128.8, 128.7, 128.6, 128.4, 127.8, 126.9, 126.9, 125.7, 61.2, 54.9, 40.9, 37.8, 14.1. $\operatorname{HRMS}(m / z):[\mathrm{M}+\mathrm{H}]^{+}$calcd for $\mathrm{C}_{28} \mathrm{H}_{28} \mathrm{~N}_{3} \mathrm{O}_{2}, 438.2182$, found, 438.2185.<smiles>CCOC(=O)C(Cc1ccco1)Nc1ncc(-c2ccccc2)nc1Cc1ccccc1</smiles>

Ethyl 2-((3-benzyl-5-phenylpyrazin-2-yl)amino)-3-(furan-2-yl)propanoate (18aB): obtained as an oil $(6.31 \mathrm{~g}, 89 \%)$ after a chromatography over silica gel (cyclohexane-ethyl acetate 95:5). ${ }^{1} \mathrm{H}$ NMR ( $\left.\mathrm{CDCl}_{3}\right): 8.42(\mathrm{~s}, 1 \mathrm{H}), 7.95(\mathrm{~m}, 2 \mathrm{H}), 7.46(\mathrm{~m}, 2 \mathrm{H}), 7.39-7.28(\mathrm{~m}, 5 \mathrm{H}), 7.22(\mathrm{~m}, 2 \mathrm{H}), 6.22$ $(\mathrm{dd}, 1 \mathrm{H}, J=3.2,1.9 \mathrm{~Hz}), 5.85(\mathrm{dd}, 1 \mathrm{H}, J=3.2,0.7 \mathrm{~Hz}), 5.13(\mathrm{~d}, 1 \mathrm{H}, J=7.5 \mathrm{~Hz}), 4.95(\mathrm{dt}, 1 \mathrm{H}, J$ $=7.5,5.3 \mathrm{~Hz}), 4.16(\mathrm{~m}, 4 \mathrm{H}), 3.21(\mathrm{~m}, 2 \mathrm{H}), 1.22(\mathrm{t}, 3 \mathrm{H}, J=7.1 \mathrm{~Hz}) .{ }^{13} \mathrm{C} \mathrm{NMR}\left(\mathrm{CDCl}_{3}\right): 172.0$, $150.6,150.3,141.9,141.2,141.1,137.5,136.8,136.6,128.8,128.7,128.7,127.8,126.8,125.7$, 110.3, 107.7, 61.3, 53.2, 40.9, 30.4, 14.1. HRMS (m/z): $[\mathrm{M}+\mathrm{H}]^{+}$calcd for $\mathrm{C}_{26} \mathrm{H}_{26} \mathrm{~N}_{3} \mathrm{O}_{3}, 428.1974$, found: 428.1965.<smiles>CCOC(=O)C(Cc1ccccc1)Nc1ncc(-c2ccc(OCc3ccccc3)cc2)nc1Cc1ccccc1</smiles> 
Ethyl (3-benzyl-5-(4-(benzyloxy)phenyl)pyrazin-2-yl)phenylalaninate (18bA): Obtained, as a white solid (4.47 g, 87\%) after a chromatography over silica gel (cyclohexane - ethyl acetate 95/5 to 94/6). ${ }^{1} \mathrm{H}$ NMR $\left(\mathrm{CDCl}_{3}\right)$ : 8.36 (s, 1H), 7.89 (m, 2H), 7.49 (m, 2H), 7.42 (m, 2H), 7.35 (m, 1H), 7.32-7.20 (m, 8H), 7.08 (m, 2H), $7.00(\mathrm{~m}, 2 \mathrm{H}), 5.15$ (s, 2H), 4.97 (m, 1H), 4.86 (d(br), 1H, J $=8.1 \mathrm{~Hz}), 4.14(\mathrm{~m}, 4 \mathrm{H}), 3.17(\mathrm{dd}, 1 \mathrm{H}, J=5.5,13.8 \mathrm{~Hz}), 3.08(\mathrm{dd}, 1 \mathrm{H}, J=6.0,13.8 \mathrm{~Hz}), 1.19(\mathrm{t}$, $3 \mathrm{H}, J=7.2 \mathrm{~Hz}) .{ }^{13} \mathrm{C} \mathrm{NMR}\left(\mathrm{CDCl}_{3}\right): 172.4,158.8,149.9,141.1,141.0,137.0,136.6,136.3$, $136.1,130.5,129.3,128.8,128.6,128.5,128.4,128.0,127.4,126.9,126.8,126.7,115.2,70.1$, 61.2, 54.9, 40.8, 37.9, 14.1. HRMS $(\mathrm{m} / z):[\mathrm{M}+\mathrm{H}]^{+}$calcd for $\mathrm{C}_{35} \mathrm{H}_{34} \mathrm{~N}_{3} \mathrm{O}_{3}, 544.2600$, found, 544.2609 .

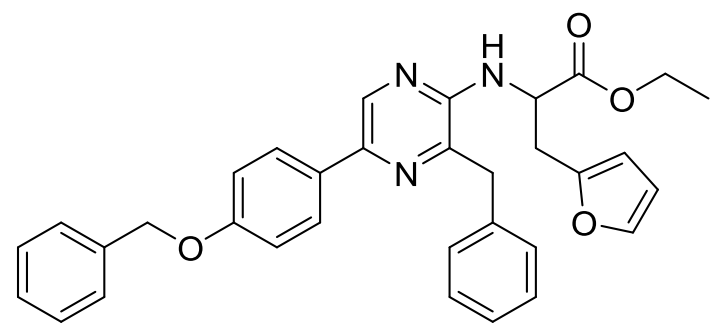

Ethyl 2-((3-benzyl-5-(4-(benzyloxy)phenyl)pyrazin-2-yl)amino)-3-(furan-2-yl)propanoate (18bB): Obtained as an oil $(0.83 \mathrm{~g}, 79 \%)$ after a chromatography over silica gel (cyclohexane ethyl acetate 94/6 to 93/7). ${ }^{1} \mathrm{H}$ NMR $\left(\mathrm{CDCl}_{3}\right)$ : 8.35 (s, 1H), 7.89 (m, 2H), 7.48 (m, 2H), 7.42 (m, 2H), $7.36(\mathrm{~m}, 1 \mathrm{H}), 7.32-7.20(\mathrm{~m}, 6 \mathrm{H}), 7.08(\mathrm{~m}, 2 \mathrm{H}), 6.22(\mathrm{dd}, 1 \mathrm{H}, J=2.0,3.0 \mathrm{~Hz}), 5.85(\mathrm{dd}, 1 \mathrm{H}$, $J=0.7,3.0 \mathrm{~Hz}), 5.15(\mathrm{~s}, 2 \mathrm{H}), 5.07(\mathrm{~d}(\mathrm{br}), 1 \mathrm{H}, J=7.6 \mathrm{~Hz}), 4.94(\mathrm{~m}, 1 \mathrm{H}), 4.16(\mathrm{~m}, 4 \mathrm{H}), 3.20$ (d, $2 \mathrm{H}, J=5.3 \mathrm{~Hz}), 1.21(\mathrm{t}, 3 \mathrm{H}, J=7.2 \mathrm{~Hz}) .{ }^{13} \mathrm{C} \mathrm{NMR}\left(\mathrm{CDCl}_{3}\right): 172.0,158.8,150.6,149.9,141.9$, 141.1, 141.0, 137.0, 136.6, 136.1, 130.5, 128.8, 128.7, 128.6, 127.9, 127.4, 126.9, 126.8, 115.2, 110.3, 107.7, 70.1, 61.2, 53.2, 40.8, 30.5, 14.1. HRMS $(\mathrm{m} / \mathrm{z}):[\mathrm{M}+\mathrm{H}]^{+}$calcd for $\mathrm{C}_{33} \mathrm{H}_{32} \mathrm{~N}_{3} \mathrm{O}_{4}$, 534.2393, found, 534.2410.<smiles>CCOC(=O)C(Cc1ccc(OCc2ccccc2)cc1)Nc1ncc(-c2ccc(OCc3ccccc3)cc2)nc1Cc1ccccc1</smiles> 
Ethyl

2-((3-benzyl-5-(4-(benzyloxy)phenyl)pyrazin-2-yl)amino)-3-(4-

(benzyloxy)phenyl)propanoate (18bC): Obtained as an oil (1.17 g, 70\%) after a chromatography over silica gel (cyclohexane - ethyl acetate 91/9 to 9/1). ${ }^{1} \mathrm{H}$ NMR $\left(\mathrm{CDCl}_{3}\right): 8.34$ (s, 1H), 7.88 (m, 2H), 7.45 (m, 4H), $7.40(\mathrm{~m}, 4 \mathrm{H}), 7.34$ (m, 2H), 7.25 (m, 3H), $7.20(\mathrm{~m}, 2 \mathrm{H}), 7.06(\mathrm{~m}, 2 \mathrm{H}), 6.91-$ $6.77(\mathrm{~m}, 4 \mathrm{H}), 5.13(\mathrm{~s}, 2 \mathrm{H}), 5.05(\mathrm{~s}, 2 \mathrm{H}), 4.90(\mathrm{~m}, 1 \mathrm{H}), 4.83(\mathrm{~m}, 1 \mathrm{H}), 4.11(\mathrm{~m}, 4 \mathrm{H}), 3.10(\mathrm{dd}, 1 \mathrm{H}$, $J=13.9,5.4 \mathrm{~Hz}), 3.01(\mathrm{dd}, 1 \mathrm{H}, J=13.9,5.9 \mathrm{~Hz}), 1.19(\mathrm{t}, 3 \mathrm{H}, J=7.1 \mathrm{~Hz}) .{ }^{13} \mathrm{C} \mathrm{NMR}\left(\mathrm{CDCl}_{3}\right)$ : $172.7,158.9,157.9,150.1,141.2,141.1,137.2,136.8,136.3,130.7,130.4,128.9,128.8,128.7$ (3 signals), 128.1, 127.6, 127.0, 115.4, 115.0, 70.2, 61.2, 55.1, 41.0, 37.1, 14.3. HRMS (m/z): $[\mathrm{M}+\mathrm{H}]^{+}$calcd for $\mathrm{C}_{42} \mathrm{H}_{40} \mathrm{~N}_{3} \mathrm{O}_{4}, 650.3019$, found, 650.3049 .

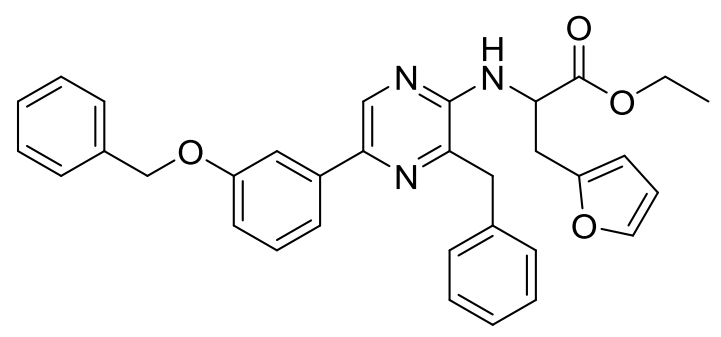

Ethyl 2-(3-benzyl-5-(3-(benzyloxy)phenyl)pyrazin-2-ylamino)-3-(furan-2-yl)propanoate (18cB): Obtained as an oil (0.63 g, 90\%, still containing traces of EtOAc) after a chromatography over silica gel (cyclohexane - ethyl acetate 97/3 to 96/4). ${ }^{1} \mathrm{H}$ NMR $\left(\mathrm{CDCl}_{3}\right): 8.39$ (s, $\left.1 \mathrm{H}\right), 7.63$ (m, 1H), $7.50(\mathrm{~m}, 3 \mathrm{H}), 7.43-7.24(\mathrm{~m}, 11 \mathrm{H}), 6.99(\mathrm{~m}, 1 \mathrm{H}), 6.23(\mathrm{dd}, 1 \mathrm{H}, J=3.1,2.0 \mathrm{~Hz}), 5.85(\mathrm{~d}, 1 \mathrm{H}$, $J=3.2 \mathrm{~Hz}), 5.16(\mathrm{~s}, 2 \mathrm{H}), 5.15(\mathrm{~d}, 1 \mathrm{H}, J=6.1 \mathrm{~Hz}), 4.96(\mathrm{~m}, 1 \mathrm{H}), 4.17(\mathrm{~s}, 2 \mathrm{H}), 4.16(\mathrm{q}, 2 \mathrm{H}, J=$ $7.1 \mathrm{~Hz}), 3.21(\mathrm{~m}, 2 \mathrm{H}), 1.22(\mathrm{t}, 3 \mathrm{H}, J=7.1 \mathrm{~Hz}) .{ }^{13} \mathrm{C} \mathrm{NMR}\left(\mathrm{CDCl}_{3}\right): 171.9,159.4,150.6,150.3$, $141.9,141.2$, 140.7, 138.9, 137.1, 136.7, 136.5, 129.8, 128.8, 128.7, 128.6, 127.9, 127.6, 126.9, 118.2, 114.5, 112.2, 110.3, 107.7, 70.1, 61.3, 53.2, 40.8, 30.4, 14.1 (one signal missing). HRMS $(\mathrm{m} / z):[\mathrm{M}+\mathrm{H}]^{+}$calcd for $\mathrm{C}_{33} \mathrm{H}_{32} \mathrm{~N}_{3} \mathrm{O}_{4}, 534.2393$, found, 534.2402.

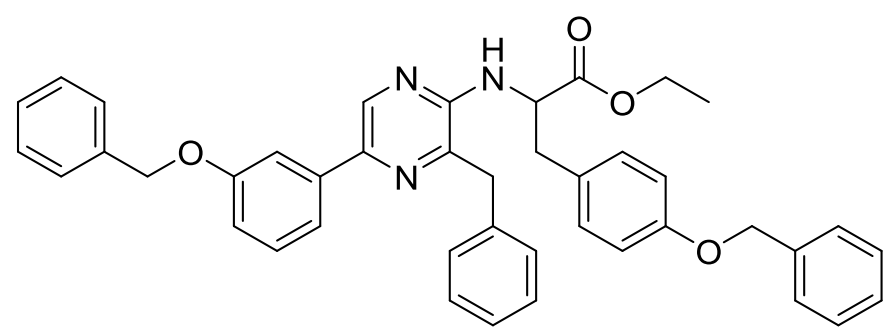


(benzyloxy)phenyl)propanoate (18cC): Obtained as an oil (0.50 g, 78\%) after a chromatography over silica gel (cyclohexane - ethyl acetate 97/3 to 96/4). ${ }^{1} \mathrm{H}$ NMR $\left(\mathrm{CDCl}_{3}\right): 8.40$ (s, 2H), 7.65 $(\mathrm{m}, 1 \mathrm{H}), 7.65-7.20(\mathrm{~m}, 17 \mathrm{H}), 6.99(\mathrm{~m}, 1 \mathrm{H}), 6.88(\mathrm{~m}, 2 \mathrm{H}), 6.83(\mathrm{~m}, 2 \mathrm{H}), 5.17(\mathrm{~s}, 2 \mathrm{H}), 5.07(\mathrm{~s}$, 2H), $4.94(\mathrm{~m}, 2 \mathrm{H}), 4.14(\mathrm{~m}, 4 \mathrm{H}), 3.13(\mathrm{~m}, 1 \mathrm{H}), 3.013(\mathrm{~m}, 1 \mathrm{H}), 1.21(\mathrm{t}, 3 \mathrm{H}, J=7.1 \mathrm{~Hz}) .{ }^{13} \mathrm{C} \mathrm{NMR}$ $\left(\mathrm{CDCl}_{3}\right)$ : 172.4, 159.4, 157.8, 150.2, 141.3, 140.6, 138.8, 137.2, 137.1, 136.4, 136.3, 130.3, $129.8,128.8,128.7,128.6,128.4,128.0,127.9,127.6,127.4,126.9,118.2,114.9,114.5,112.2$, 70.1, 70.0, 61.2, 55.0, 40.8, 36.9, 14.1 (one signal missing). HRMS $(m / z):[\mathrm{M}+\mathrm{H}]^{+}$calcd for $\mathrm{C}_{42} \mathrm{H}_{40} \mathrm{~N}_{3} \mathrm{O}_{4}, 650.3019$, found, 650. 3016.

Procedure for the synthesis of O-acetylated compounds 20aA-B, 20b-C, 20cB-C. In a sealable vessel, the considered N-pyrazyl aminoester $18(1.0 \mathrm{mmol})$ and sodium hydroxide $(0.16$ $\mathrm{g}, 4 \mathrm{mmol})$ were weighted. The air was replaced with argon and anhydrous THF (5 mL) was injected. This was stirred at $20{ }^{\circ} \mathrm{C}$ under an inert atmosphere (a balloon inflated with argon) overnight and acetic anhydride $(1.4 \mathrm{~mL}, 15.0 \mathrm{mmol})$ was then injected. After stirring an additional two hours under an inert atmosphere at room temperature, this was diluted in ethyl acetate, washed with water, brine and concentrated to dryness. The traces of acetic acid and acetic anhydride were removed by co-evaporation with toluene and then cyclohexane and the residue further purified as described below.



2,8-Dibenzyl-6-phenylimidazo[1,2-a]pyrazin-3-yl acetate (20aA): Obtained as a yellowish solid $(0.17 \mathrm{~g}, 50 \%)$ after a recrystallization in cyclohexane. ${ }^{1} \mathrm{H}$ NMR $\left(\mathrm{CDCl}_{3}\right): 7.92(\mathrm{~m}, 2 \mathrm{H}), 7.80(\mathrm{~s}$, 1H), $7.64(\mathrm{~m}, 2 \mathrm{H}), 7.47(\mathrm{~m}, 2 \mathrm{H}), 7.40(\mathrm{~m}, 1 \mathrm{H}), 7.33(\mathrm{~m}, 5 \mathrm{H}), 7.25(\mathrm{~m}, 2 \mathrm{H}), 4.65(\mathrm{~s}, 2 \mathrm{H}), 4.23(\mathrm{~s}$, 2H), 2.18 (s, 3H). ${ }^{13} \mathrm{C}$ NMR $\left(\mathrm{CDCl}_{3}\right): 167.1,152.9,139.1,137.9,137.8,136.8,135.1,133.5$, 
129.8, 129.1, 128.9, 128.8, 128.6, 128.5, 128.3, 126.5 (two signals), 126.4, 108.8, 39.4, 34.2, 19.9. HRMS $(m / z):[\mathrm{M}+\mathrm{H}]^{+}$calcd for $\mathrm{C}_{28} \mathrm{H}_{24} \mathrm{~N}_{3} \mathrm{O}_{2}, 434.1869$, found, 434.1825 .



8-benzyl-2-(furan-2-ylmethyl)-6-phenylimidazo[1,2-a]pyrazin-3-yl acetate (20aB): Obtained as an off-white solid $(4.02 \mathrm{~g}, 72 \%)$ after a recrystallization in cyclohexane. ${ }^{1} \mathrm{H}$ NMR $\left(\mathrm{CDCl}_{3}\right): 7.92$ (m, 2H), 7.83 (s, 1H), $7.63(\mathrm{~m}, 2 \mathrm{H}), 7.47$ (m, 2H), 7.42-7.30 (m, 4H), $7.23(\mathrm{~m}, 1 \mathrm{H}), 6.35(\mathrm{~m}, 1 \mathrm{H})$, $6.16(\mathrm{~m}, 1 \mathrm{H}), 4.64(\mathrm{~s}, 2 \mathrm{H}), 4.24(\mathrm{~s}, 2 \mathrm{H}), 2.36(\mathrm{~s}, 3 \mathrm{H}),{ }^{13} \mathrm{C} \mathrm{NMR}\left(\mathrm{CDCl}_{3}\right)$ : 167.0, 153.0, 151.5, 141.5, 139.2, 137.8, 136.7, 133.5, 132.5, 129.7, 128.9, 128.8, 128.6, 128.3, 126.5, 126.4, 110.5, 108.9, 106.8, 39.3, 27.2, 20.1. HRMS $(\mathrm{m} / \mathrm{z}):[\mathrm{M}+\mathrm{H}]^{+}$calcd for $\mathrm{C}_{26} \mathrm{H}_{22} \mathrm{~N}_{3} \mathrm{O}_{3}, 424.1661$, found, 424.1607.

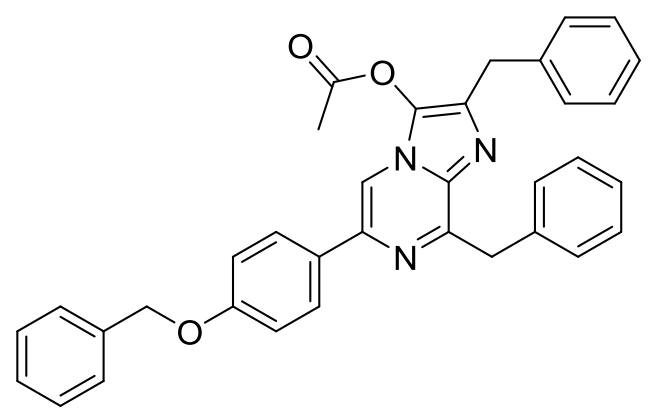

2,8-Dibenzyl-6-(4-(benzyloxy)phenyl)imidazo[1,2-a]pyrazin-3-yl acetate (20bA): Obtained as an off-white solid $(0.44 \mathrm{~g})$ pure enough (traces of THF and acetic acid) to be used directly in the next step. ${ }^{1} \mathrm{H}$ NMR $\left(\mathrm{CDCl}_{3}\right): 7.83(\mathrm{~m}, 2 \mathrm{H}), 7.72(\mathrm{~s}, 1 \mathrm{H}), 7.63(\mathrm{~m}, 2 \mathrm{H}), 7.47(\mathrm{~m}, 2 \mathrm{H}), 7.48-7.21$

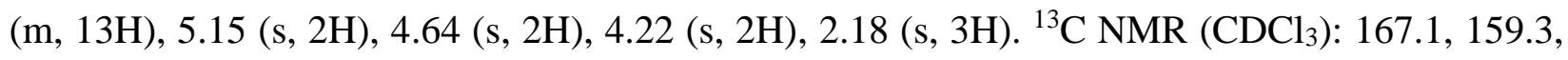
152.7, 139.0, 138.1, 137.9, 136.9, 135.0, 133.4, 129.7, 129.6, 129.1, 128.8, 128.6, 128.5, 128.3, 128.0, 127.7, 127.4, 126.5, 126.4, 115.2, 107.9, 70.1, 39.4, 34.2, 19.8. HRMS $(\mathrm{m} / \mathrm{z}):[\mathrm{M}+\mathrm{H}]^{+}$ calcd for $\mathrm{C}_{35} \mathrm{H}_{30} \mathrm{~N}_{3} \mathrm{O}_{3}, 540.2287$, found, 540.2275. 


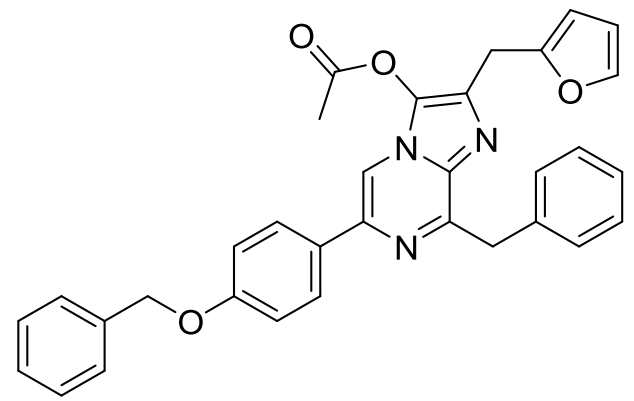

8-Benzyl-6-(4-(benzyloxy)phenyl)-2-(furan-2-ylmethyl)imidazo[1,2-a]pyrazin-3-yl acetate (20bB): Obtained as an off-white solid (1.13 g) pure enough (traces of acetic acid) to be used directly in the next step. ${ }^{1} \mathrm{H}$ NMR $\left(\mathrm{CDCl}_{3}\right): 7.85(\mathrm{~m}, 2 \mathrm{H}), 7.75(\mathrm{~s}, 1 \mathrm{H}), 7.61(\mathrm{~m}, 2 \mathrm{H}), 7.47$ (m, 2H), 7.44-7.21 (m, 7H), $7.07(\mathrm{~m}, 2 \mathrm{H}), 6.37(\mathrm{~m}, 1 \mathrm{H}), 6.16(\mathrm{~m}, 1 \mathrm{H}), 5.15(\mathrm{~s}, 2 \mathrm{H}), 4.62(\mathrm{~s}, 2 \mathrm{H}), 4.24$ (s, 2H), 2.35 (s, 3H). ${ }^{13} \mathrm{C} \mathrm{NMR}\left(\mathrm{CDCl}_{3}\right): 167.1,159.3,152.8,151.5,141.6,139.1,137.8,136.8$, 133.4, 132.3, 129.7, 129.6, 128.8, 128.6, 128.3, 128.0, 127.7, 127.4, 126.4, 115.2, 110.5, 107.9, 106.8, 70.1, 39.3, 27.2, 20.1. HRMS $(\mathrm{m} / \mathrm{z})$ : $[\mathrm{M}+\mathrm{H}]^{+}$calcd for $\mathrm{C}_{33} \mathrm{H}_{28} \mathrm{~N}_{3} \mathrm{O}_{4}, 530.2080$, found, 530.2070 .

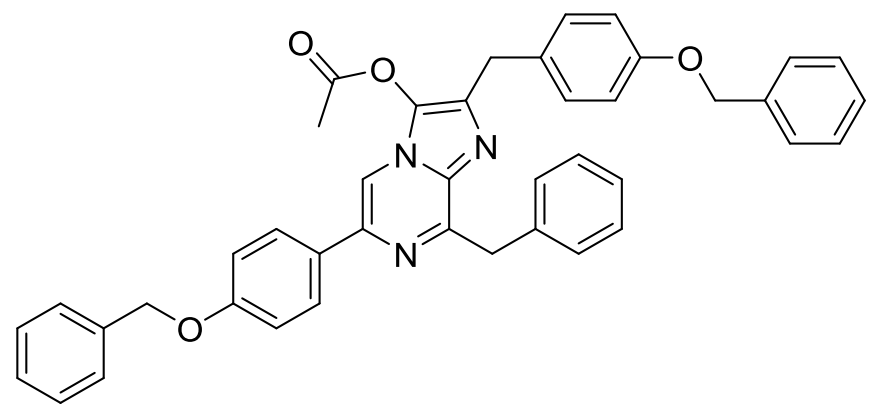

8-Benzyl-2-(4-(benzyloxy)benzyl)-6-(4-(benzyloxy)phenyl)imidazo[1,2-a]pyrazin-3-yl acetate (20bC): Obtained as an off-white solid $(0.51 \mathrm{~g})$ which was used directly in the next step. ${ }^{1} \mathrm{H}$ NMR $\left(\mathrm{CDCl}_{3}\right): 7.84(\mathrm{~m}, 2 \mathrm{H}), 7.71(\mathrm{~s}, 1 \mathrm{H}), 7.61(\mathrm{~m}, 2 \mathrm{H}), 7.48$ - $7.29(\mathrm{~m}, 12 \mathrm{H}), 7.25$ - 7.20 (m, 3H), $7.06(\mathrm{~m}, 2 \mathrm{H}), 6.94(\mathrm{~m}, 2 \mathrm{H}), 5.14$ (s, 2H), 5.09 (s, 2H), 4.62 (s, 2H), 2.17 (s, 3H). ${ }^{13} \mathrm{C} \mathrm{NMR}$ $\left(\mathrm{CDCl}_{3}\right)$ : 167.1, 159.3, 157.9, 152.7, 138.9, 137.9, 137.1, 136.9, 135.4, 133.5, 130.4, 130.0, $129.7,128.7,128.6,128.5,128.2$, 128.0, 127.9, 127.7, 127.5, 127.4, 126.4, 115.2, 114.9, 107.8, 
70.1, 70.0, 39.4, 33.4, 26.9, 19.9. HRMS $(\mathrm{m} / \mathrm{z})$ : $[\mathrm{M}+\mathrm{H}]^{+}$calcd for $\mathrm{C}_{42} \mathrm{H}_{36} \mathrm{~N}_{3} \mathrm{O}_{4}, 646.2706$, found, 646.2728 .

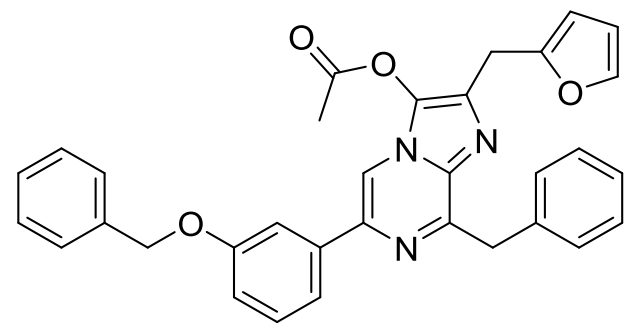

8-Benzyl-6-(3-(benzyloxy)phenyl)-2-(furan-2-ylmethyl)imidazo[1,2-a]pyrazin-3-yl acetate (20cB): Obtained as an oil $(0.55 \mathrm{~g})$ still containing a small amount of cyclohexane which was used in the next step without further purification. ${ }^{1} \mathrm{H}$ NMR $\left(\mathrm{CDCl}_{3}\right): 7.83(\mathrm{~s}, 1 \mathrm{H}), 7.61(\mathrm{~m}, 3 \mathrm{H})$, 7.49 (m, 3H), 7.45-7.21 (m, 8H), $7.02(\mathrm{~m}, 1 \mathrm{H}), 6.36(\mathrm{dd}, 1 \mathrm{H}, J=3.1,1.9 \mathrm{~Hz}), 6.17(\mathrm{dd}, 1 \mathrm{H}, \mathrm{J}=$ 3.2, $0.8 \mathrm{~Hz}), 5.14(\mathrm{~s}, 2 \mathrm{H}), 4.65$ (s, 2H), 4.25 (s, 2H), 2.36 (s, 3H). ${ }^{13} \mathrm{C} \mathrm{NMR}\left(\mathrm{CDCl}_{3}\right): 167.0$, 159.3, 152.9, 151.4, 141.7, 138.9, 138.1, 137.7, 136.9, 133.4, 132.4, 129.8 (two signals), 128.9, 128.6, 128.3, 128.0, 127.6, 126.5, 118.8, 115.1, 113.3, 110.5, 109.0, 106.9, 70.2, 39.3, 27.1, 20.1. HRMS (m/z): $[\mathrm{M}+\mathrm{H}]^{+}$calcd for $\mathrm{C}_{33} \mathrm{H}_{28} \mathrm{~N}_{3} \mathrm{O}_{4}, 530.2080$, found, 530.2084 .



8-Benzyl-2-(4-(benzyloxy)benzyl)-6-(3-(benzyloxy)phenyl)imidazo[1,2-a]pyrazin-3-yl acetate (20cC): Obtained as a white solid $(0.5 \mathrm{~g}, 77 \%)$ after a recrystallization in cyclohexane. ${ }^{1} \mathrm{H}$ NMR $\left(\mathrm{CDCl}_{3}\right): 7.79(\mathrm{~s}, 1 \mathrm{H}), 7.61(\mathrm{~m}, 3 \mathrm{H})$, 7.51-7.30 (m, 14H), $7.23(3 \mathrm{H}), 7.01(\mathrm{~m}, 1 \mathrm{H}), 6.94(\mathrm{~m}, 2 \mathrm{H})$, 5.14 (s, 2H), 5.09 (s, 2H), 4.64 (s, 2H), 4.16 (s, 2H), 2.18 (s, 3H). ${ }^{13} \mathrm{C}$ NMR $\left(\mathrm{CDCl}_{3}\right):$ 167.1, 159.3, 157.5, 152.8, 138.7, 138.3, 137.8, 137.2, 137.0, 135.5, 133.6, 130.3, 130.1, 129.8, 129.7, $128.8,128.6,128.5,128.3,128.0,127.9,127.6,127.4,126.4,118.8,115.0,114.9,113.2,108.9$, 70.2, 70.1, 39.4, 33.3, 19.9. HRMS $(\mathrm{m} / \mathrm{z})$ : MIA. 
General protocol for the debenzylation of compounds $20 \mathrm{bA}-\mathrm{C}, 20 \mathrm{cB}-\mathrm{C}$ into compounds 20dA-B, 20dD, 20eB and 20eD. The considered O-acetylated luciferin $(1.05 \mathrm{mmol})$ and $10 \%$ palladium over charcoal $(0.11 \mathrm{~g}, 0.105 \mathrm{mmol})$ were dispersed in ethyl acetate $(20 \mathrm{~mL})$, ethanol $(20 \mathrm{~mL})$ and acetic acid $(6 \mathrm{~mL})$. This was charged in hydrogen and stirred for 10-20 hours. Note: depending on the quality of the catalyst used, over-hydrogenation was sometime an issue, especially with the furan-bearing substrates. The resulting suspension was filtered, concentrated to dryness and the residue purified by chromatography as described below. Note: pre-adsorption of this residue over a small portion of silica gel before the chromatography was made using ethyl acetate without heating and no delay was taken before undertaking the purification by chromatography.<smiles>CC(=O)Oc1c(Cc2ccccc2)nc2c(Cc3ccccc3)nc(-c3ccc(O)cc3)cn12</smiles>

2,8-Dibenzyl-6-(4-hydroxyphenyl)imidazo[1,2-a]pyrazin-3-yl acetate (20dA): This compound was obtained as a white cotton $(0.1 \mathrm{~g}, 27 \%$ from 18aA $)$ after a chromatography over silica gel (cyclohexane - ethyl acetate 4/1 to 3/1). ${ }^{1} \mathrm{H}$ NMR (DMSO- $d_{6}$ ): 9.64 (s, 1H), 8.54 (s, 1H), 7.89 (m, 2H), $7.48(\mathrm{~m}, 2 \mathrm{H}), 7.26(\mathrm{~m}, 8 \mathrm{H}), 6.87(\mathrm{~m}, 2 \mathrm{H}), 4.46(\mathrm{~s}, 2 \mathrm{H}), 4.08(\mathrm{~s}, 2 \mathrm{H}), 2.37(\mathrm{~s}, 3 \mathrm{H}) .{ }^{13} \mathrm{C}$ NMR (DMSO- $d_{6}$ ): $168.5,158.5,151.9,139.0,138.4,138.2$, 135.3, 133.3, 129.7, 129.3, 129.1, $128.8,128.7,127.9,127.5,126.8,126.7,115.9,109.4,39.2,33.0,20.7$. HRMS $(m / z):[\mathrm{M}+\mathrm{H}]^{+}$ calcd for $\mathrm{C}_{28} \mathrm{H}_{24} \mathrm{~N}_{3} \mathrm{O}_{3}: 450.1818$, found, 450.1825 . 
<smiles>CC(=O)Oc1c(Cc2ccco2)nc2c(Cc3ccccc3)nc(-c3ccc(O)cc3)cn12</smiles>

8-Benzyl-2-(furan-2-ylmethyl)-6-(4-hydroxyphenyl)imidazo[1,2-a]pyrazin-3-yl acetate (20dB): This compound was obtained as a white cotton $(0.37 \mathrm{~g}, 39 \%$ from 18aB $)$ after a chromatography over silica gel (cyclohexane - ethyl acetate 3/1). ${ }^{1} \mathrm{H}$ NMR (DMSO- $\left.d_{6}\right)$ : 9.65 (s, 1H), 8.55 (s, 1H), $7.90(\mathrm{~m}, 2 \mathrm{H}), 7.55(\mathrm{~m}, 1 \mathrm{H}), 7.47(\mathrm{~m}, 2 \mathrm{H}), 7.27$ (m, 2H), $7.22(\mathrm{~m}, 1 \mathrm{H}), 6.88(\mathrm{~m}, 2 \mathrm{H}), 6.39$ (dd, $1 \mathrm{H}, J=1.8,3.1 \mathrm{~Hz}), 6.19(\mathrm{dd}, 1 \mathrm{H}, J=0.8,3.1 \mathrm{~Hz}), 4.46(\mathrm{~s}, 2 \mathrm{H}), 4.13(\mathrm{~s}, 2 \mathrm{H}), 2.40(\mathrm{~s}, 3 \mathrm{H}) .{ }^{13} \mathrm{C}$ NMR (DMSO-d $)$ : 168.4, 158.5, 152.0, 151.9, 142.4, 138.4, 138.3, 133.1, 132.6, 129.6, 129.2, $128.8,127.9,127.5,126.8,115.9,111.0,109.4,107.2$, 39.1, 26.8, 20.8. HRMS $(m / z):[\mathrm{M}+\mathrm{H}]^{+}$ calcd for $\mathrm{C}_{26} \mathrm{H}_{22} \mathrm{~N}_{3} \mathrm{O}_{4}, 440.1610$, found, 440.1603.<smiles>CC(=O)Oc1c(Cc2ccc(O)cc2)nc2c(Cc3ccccc3)nc(-c3ccc(O)cc3)cn12</smiles>

8-Benzyl-2-(4-hydroxybenzyl)-6-(4-hydroxyphenyl)imidazo[1,2-a]pyrazin-3-yl acetate (20dD): This compound was obtained as a beige solid $(0.10 \mathrm{~g}, 27 \%$ from $20 \mathrm{bC})$ after a chromatography over silica gel (cyclohexane - ethyl acetate 2/1). ${ }^{1} \mathrm{H}$ NMR (DMSO- $\left.d_{6}\right) 9.65(\mathrm{~s}, 1 \mathrm{H}), 9.20(\mathrm{~s}, 1 \mathrm{H})$, $8.53(\mathrm{~s}, 1 \mathrm{H}), 7.89(\mathrm{~m}, 2 \mathrm{H}), 7.48(\mathrm{~m}, 2 \mathrm{H}), 7.24(\mathrm{~m}, 3 \mathrm{H}), 7.07(\mathrm{~m}, 2 \mathrm{H}), 6.87(\mathrm{~m}, 2 \mathrm{H}), 6.69(\mathrm{~m}, 2 \mathrm{H})$, 4.46 (s, 2H), 3.96 (s, 2H), 2.37 (s, 3H). ${ }^{13} \mathrm{C}$ NMR (DMSO- $\left.d_{6}\right): 168.5,158.4,156.2,151.8,138.5$, 138.2, 136.0, 133.2, 130.2, 129.7, 129.1, 128.9, 128.7, 127.9, 127.6, 126.8, 115.9, 115.5, 109.3, 39.2, 32.3, 20.7. HRMS (m/z): [M+H] ${ }^{+}$calcd for $\mathrm{C}_{28} \mathrm{H}_{24} \mathrm{~N}_{3} \mathrm{O}_{4}$ : 466.1767, found, 466.1758 . 
<smiles>CC(=O)Oc1c(Cc2ccco2)nc2c(Cc3ccccc3)nc(-c3cccc(O)c3)cn12</smiles>

8-Benzyl-2-(furan-2-ylmethyl)-6-(3-hydroxyphenyl)imidazo[1,2-a]pyrazin-3-yl acetate (20eB): This compound was obtained as a red powder $(0.12 \mathrm{~g}, 26 \%$ from $20 \mathbf{c B})$ after a chromatography over silica gel (cyclohexane - ethyl acetate 2/1). ${ }^{1} \mathrm{H}$ NMR (DMSO- $\left.d_{6}\right) 9.53(\mathrm{~s}, 1 \mathrm{H}), 8.67(\mathrm{~s}, 1 \mathrm{H})$, 7.55 (m, 1H), $7.52(\mathrm{~m}, 1 \mathrm{H}), 7.48(\mathrm{~m}, 3 \mathrm{H}), 7.32-7.19(\mathrm{~m}, 4 \mathrm{H}), 6.80$ (ddd, 1H, J = 7.6, 2.0, 1.0 Hz), $6.39(\mathrm{dd}, 1 \mathrm{H}, J=3.2,2.0 \mathrm{~Hz}), 6.19(\mathrm{dd}, 1 \mathrm{H}, J=3.2,1.0 \mathrm{~Hz}), 4.48$ (s, 2H), 4.15 (s, 2H), 2.40 (s, $3 \mathrm{H}) .{ }^{13} \mathrm{C}$ NMR (DMSO-d $)$ ): 168.4, 158.2, 152.1, 151.9, 142.5, 138.3, 138.0, 133.4, 132.8, 130.0, 129.6, 129.7, 129.4, 128.8, 126.9, 117.3, 116.0, 113.7, 111.1, 111.0, 107.2, 39.1, 20.8, 14.5. $\operatorname{HRMS}(m / z):[\mathrm{M}+\mathrm{H}]^{+}$calcd for $\mathrm{C}_{26} \mathrm{H}_{22} \mathrm{~N}_{3} \mathrm{O}_{4}$ : 440. 1610, found, 440.1619 .<smiles>CC(=O)Oc1c(Cc2ccc(O)cc2)nc2c(Cc3ccccc3)nc(-c3cccc(O)c3)cn12</smiles>

8-Benzyl-2-(3-hydroxybenzyl)-6-(4-hydroxyphenyl)imidazo[1,2-a]pyrazin-3-yl acetate (20eD): This compound was obtained as a yellow powder $(0.11 \mathrm{~g}, 32 \%)$ after a chromatography over silica gel (cyclohexane - ethyl acetate 2/1). ${ }^{1} \mathrm{H}$ NMR (DMSO- $\left.d_{6}\right) 9.56(\mathrm{~s}, 1 \mathrm{H}), 9.24(\mathrm{~s}, 1 \mathrm{H}), 8.64$ (s, 1H), $7.50(\mathrm{~m}, 4 \mathrm{H}), 7.25(\mathrm{~m}, 4 \mathrm{H}), 7.08(\mathrm{~m}, 2 \mathrm{H}), 6.83(\mathrm{~m}, 1 \mathrm{H}), 6.70(\mathrm{~m}, 2 \mathrm{H}), 4.48(\mathrm{~s}, 2 \mathrm{H}), 3.97$ (s, 2H), 2.37 (s, 3H). ${ }^{13} \mathrm{C}$ NMR (DMSO-d $)$ ): 168.6, 158.2, 156.2, 152.0, 138.4, 138.1, 137.9, 136.2, 133.4, 130.2, 129.7, 129.1, 129.0, 128.8, 126.9, 117.4, 116.0, 115.6, 115.5, 113.7, 111.0, 39.2, 32.3, 20.7. HRMS (m/z): $[\mathrm{M}+\mathrm{H}]^{+}$calcd for $\mathrm{C}_{28} \mathrm{H}_{24} \mathrm{~N}_{3} \mathrm{O}_{4}: 466.1767$, found, 466.1767 . 


\section{General protocol for the generation of solutions of luciferins from the $\mathbf{O}$-acetylated luciferin.}

The considered O-acetylated luciferin (1 mg) was dissolved in DMSO $(0.2 \mathrm{~mL})$ and then diluted by adding a solution of acidic ethanol $(0.3 \mathrm{ml})$ made from the addition of $37 \%$ hydrochloric acid $(100 \mu \mathrm{l})$ on $100 \%$ ethanol $(12 \mathrm{~mL})$. This $0.5 \mathrm{~mL}$ solution was incubated at $50^{\circ} \mathrm{C}$ for 2 to $3 \mathrm{~h}$ to give a stock solution which was then stored at $-80^{\circ} \mathrm{C}$. As depicted in figure $\mathrm{S} 1$, the LC/MS monitoring of the hydrolysis of the O-acetylated luciferin 20a-B into the corresponding luciferin 5a-B was complete and clean in less than two hours. 

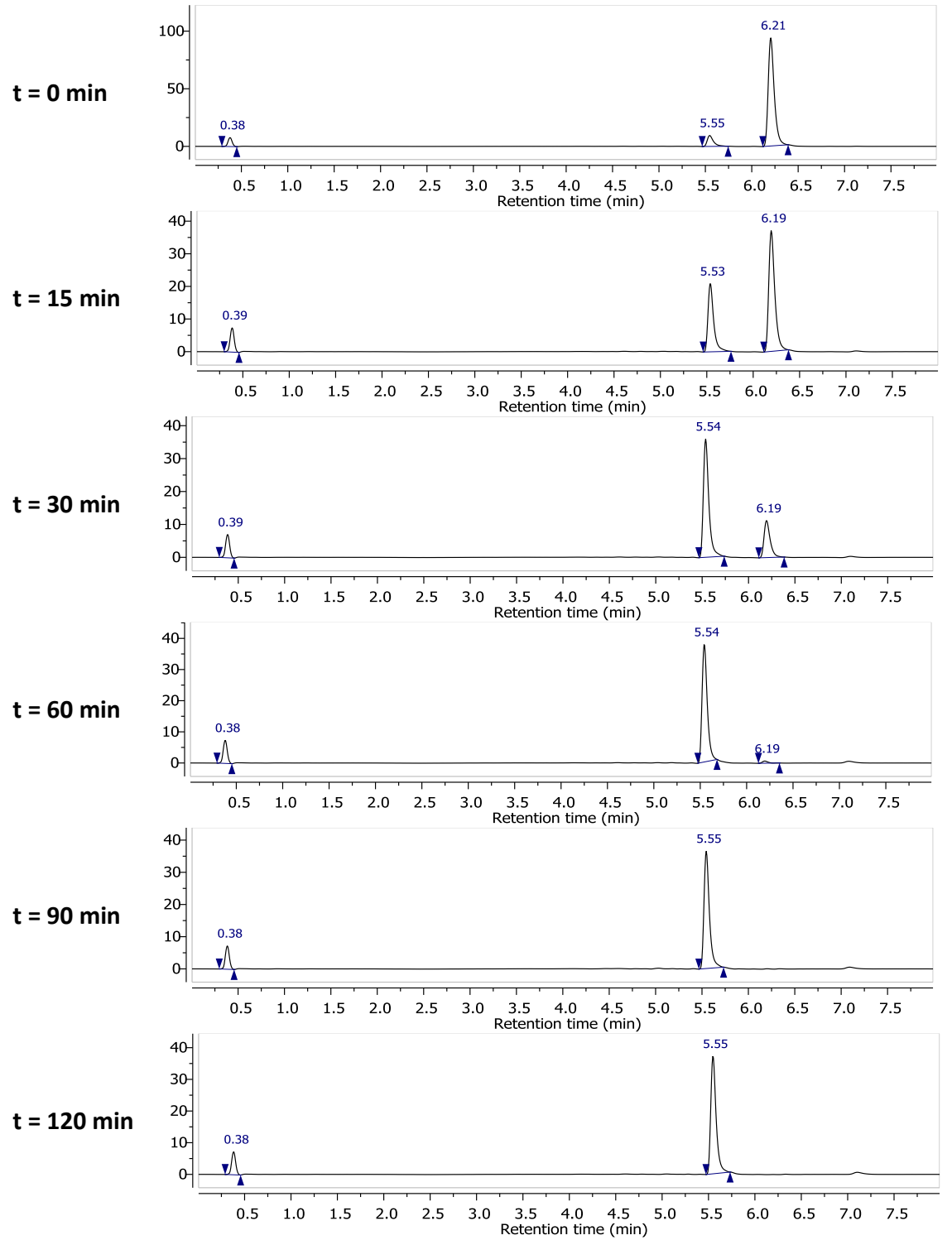

Figure S1. HPLC profiles, obtained on an Agilent apparatus, with a $3.5 \mu \mathrm{m}$ XDB-C18 column, elution: 5:95 to 95:5 $\mathrm{H}_{2} \mathrm{O} / \mathrm{MeOH}$ in $3.5 \mathrm{~min}$, with constant $5 \mathrm{mM}$ ammonium formate. Peak at $\mathrm{t}_{\mathrm{R}}$ $=5.5$ is compound 5a-B $\left(\mathrm{m} / \mathrm{z}[\mathrm{M}+\mathrm{H}]^{+}=382\right)$, peak at $\mathrm{t}_{\mathrm{R}}=6.2 \mathrm{~min}$ is the O-acetylated compound 20a-B $\left(m / z[\mathrm{M}+\mathrm{H}]^{+}=424\right)$. 


\section{Biochemistry}

\section{NanoKAZ expression, purification and quality validation}

The nanoKAZ luciferase ${ }^{5}$ was expressed from a codon-optimized sequence of the gene coding for the previously reported ${ }^{6}$ NanoLuc, the mutated catalytic domain of the luciferase from Oplophorus gracilostris featuring 16 amino acid substitutions. The gene nanoKAZ was synthetized by Eurofins (Germany) with carboxy-end His6-tag (in caps) and flanking region corresponding to the pET23 sequence (Novagen).

Atggtcttcacactcgaagatttcgttggggactggcgacagacagccggctacaacctggaccaagtccttgaacagggaggtgtgtcca gtttgtttcagaatctcggggtgtccgtaactccgatccaaaggattgtcctgagcggtgaaaatgggetgaagatcgacatccatgtcatcat cccgtatgaaggtctgagcggcgaccaaatgggccagatcgaaaaaattttaaggtggtgtaccctgtggatgatcatcactttaaggtgat cctgcactatggcacactggtaatcgacggggttacgccgaacatgatcgactatttcggacggccgtatgaaggcatcgecgtgttcgacg gcaaaaagatcactgtaacagggaccetgtggaacggcaacaaaattatcgacgagcgectgatcaaccccgacggetccetgctgttccg agtaaccatcaacggagtgaccggetggeggetgtgcgaacgcattctggcgCTCGAGCACCACCACCACCACCAC TGA

The pET23 plasmid was amplified with the forward and reverse oligonucleotides (Fwd:5'CTCGAGCACCACCACCACCACCAC3'; Rvr:5'GGTATATCTCCTTCTTAAAGTTAAAC3', Eurofins) using a Q5 DNA polymerase, dNTP mix (New England BioLabs). PCR product was purified by electrophoresis on agarose gel (1\%, Macherey-Nagel). Purified pET23 vector and the synthetic gene were assembly using NEBuilder HiFi assembly master mix (New England BioLabs). The assembled product (5 $\square \mathrm{L}$ ) was used to transform NEB 5-alpha competent E. coli and grown overnight on LB/Agar/ampicillin in Petri dish. Isolated colonies were grown in liquid medium, plasmid was isolated and nucleotide sequence was performed to confirm the presence of the insert (Eurofins).

The pET23-kaz was used to transform E.coli BL21 (DE3) to achieve high expression in E.coli. Cell were grown at $18{ }^{\circ} \mathrm{C}$ and IPTG was added to induce nanoKAZ production. After harvesting 
the cells by centrifugation $(1.5 \mathrm{~L})$, pellet was resuspended in $50 \mathrm{mM}$ Tris- $\mathrm{HCl} \mathrm{pH} 8.0,50 \mathrm{mM}$ $\mathrm{NaCl}$ with protease inhibitors (Sigma) and lysozyme $(0.1 \mathrm{mg} / \mathrm{mL}$ ). Cells were disrupted by freezing-thawing cycle lysis method. DNase I (Sigma-Aldrich) was then added to remove DNA from the sample.

The crude extract was centrifuged $30 \mathrm{~min}$ at $1250 \mathrm{~g}$. The supernatant was collected and $\mathrm{NaCl}$ $(500 \mathrm{mM})$, imidazole $(20 \mathrm{mM})$ and Triton X100 $(0.1 \%)$ were added. Then this cleared lysate was loaded on a His-Trap HP column ( $5 \mathrm{~mL}$, GE-Healthcare) at a flow rate of $4 \mathrm{~mL} / \mathrm{min}$ using an AKTA pure chromatography system (GE-Healthcare). The column was washed with 20 volumes of column with a running buffer ( $50 \mathrm{mM}$ Tris- $\mathrm{HCl} \mathrm{pH} \mathrm{8.0,50} \mathrm{mM} \mathrm{NaCl}, 20 \mathrm{mM}$ imidazole) at 5 $\mathrm{mL} / \mathrm{min}$. The nanoKAZ was eluted with a gradient of imidazole from $20 \mathrm{mM}$ to $200 \mathrm{mM}$ in 50 $\mathrm{mM}$ Tris- $\mathrm{HCl} \mathrm{pH} 8.0,50 \mathrm{mM} \mathrm{NaCl}$ at $5 \mathrm{~mL} / \mathrm{min}$ and fractions of $1 \mathrm{~mL}$ were collected in 96deepwell plate (GE-Heath). Catalytic activity of fractions was profiled using a luminometer Hydex by diluting $10^{7}$ folds the fractions in PBS with $27 \square \mathrm{M}$ of furimazine (8-benzyl-2-(furan-2ylmethyl)-6-phenylimidazo[1,2-a]pyrazin-3(7H)-one). The fractions of high activity were pooled, and loaded on a HiTrap Q column (1 mL, GE-Healthcare) equilibrated in $50 \mathrm{mM}$ Tris-HCl pH $8.0, \mathrm{NaCl} 50 \mathrm{mM}$. The protein was eluted in $50 \mathrm{mM}$ MES pH $6.5,50 \mathrm{mM} \mathrm{NaCl}$ at $1 \mathrm{~mL} / \mathrm{min}$ at $18^{\circ} \mathrm{C}$ using the AKTA pure chromatography system. The fractions of $500 \square \mathrm{L}$ were collected in 96-deepwell plates and their activities were assayed as described above. The fractions of high activity were pooled. An UV-spectrum (240-300nm) was acquired for evaluating the concentration of nanoKAZ from the solution absorption at $280 \mathrm{~nm}$. The extinction coefficient was estimated by the method of Gill and von $\mathrm{Hippel}^{7}$ from the residue sequence of nanoKAZ $\left(\square_{280 \mathrm{~nm}}=24750 \mathrm{M}^{-1} \cdot \mathrm{cm}^{-1}\right)$. The specific activity is about $92 \cdot 10^{9}$ acquired photons / $\mathrm{s} / \mathrm{mg}$ of nanoKAZ.

As depicted in figure S2, the quality of the purified protein was assessed by loading a $2 \square \mathrm{L}$ aliquot on a stain-free SDS gel (4-15\% Mini-PROTEAN® TGX Stain-Free ${ }^{\mathrm{TM}}$ Protein Gels, BioRad). The gel was activated by UV trans-illumination for 5 min (Bio-Gel Doc XR Imaging System) and fluorescence of tryptophan in protein bands were imaged. The gel was then transferred on nitrocellulose (ECL membrane, GE-Healthcare) and revealed using a mouse HRPcoupled IgG anti-His-tag (Invitrogen). 


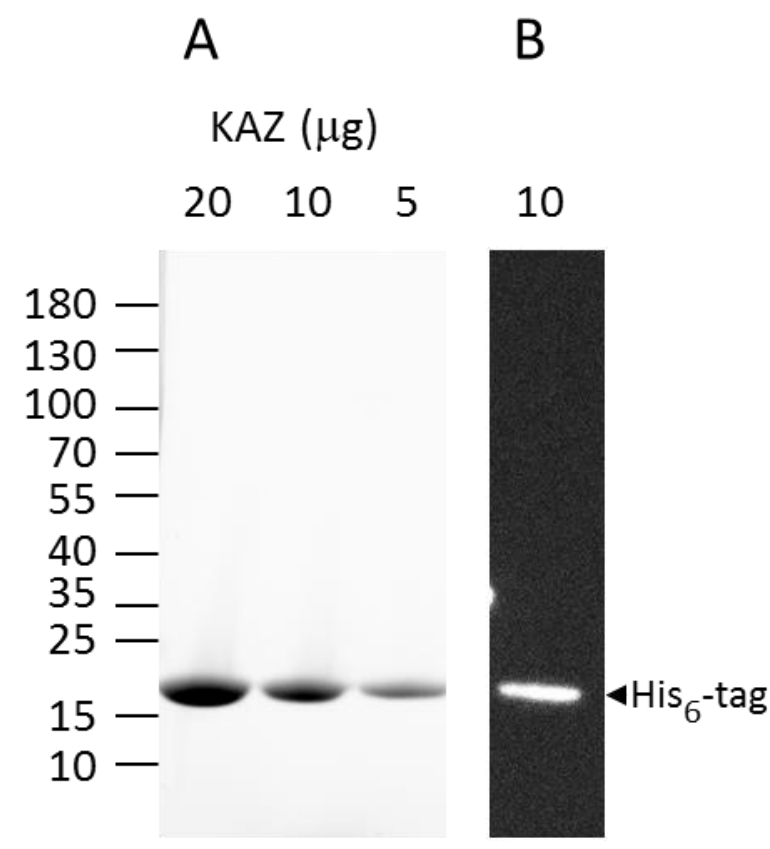

Figure S2. SDS-PAGE and western blot of purified nanoKAZ luciferase. The molecular weight scale $(\mathrm{kDa})$ is indicated on the left. (A) The lanes from left to right show stained nanoKAZ bands (19 kDa) corresponding to 20,10 and $5 \square \mathrm{g}$ solution samples respectively. (B) The lane shows the immunoprint of nanoKAZ band (19 kDa, $10 \square \mathrm{g})$ revealed through its C-end His $_{6}$-tag by a HRP-coupled anti-His tag in the presence of bioluminescent HRP substrate (Supersignal West Femto, ThermoFisher Scientific). 


\section{Bioluminescence assays}

In 96-well white flat bottom plate (Costar), $50 \mu \mathrm{L} /$ well were loaded from a $1 / 50^{\text {th }}$ dilution of the stock $(5.4 \mathrm{mM})$ imidazo[1,2-a]pyrazin-3(7H)-ones solution in DPBS (Gibco) $+0.1 \%(\mathrm{v} / \mathrm{v})$ Tween 20 (Sigma-Aldrich). Note: the pH of DPBS (Gibco) is between 7.0 and 7.3; results may vary with a different $\mathrm{pH}$. Spontaneous luminescence emission intensity displayed by the different luciferin analogues was measured on 3 points using a Berthold CentroXS luminometer (integration time of 1 second, $22^{\circ} \mathrm{C}$ ). The nanoKAZ solution (at $50 \mathrm{ng} / \mathrm{L}$ ) was diluted $10^{6}$ times in PBS/tween buffer and $50 \square \mathrm{L}$ was added per well. The plate was orbitally shaked for 5 seconds, then the luminescence signal intensity was measured per well over 2 hours, integrating $1 \mathrm{~s} /$ well every 3 minutes at $22^{\circ} \mathrm{C}$. Given the design of the experiment, the first measurement of luminescence occurred 20 seconds after addition of the luciferase. In order to get the maximum intensities for extremely fast-decaying substrates, we acquired individually kinetics for each of substrates for 4 minutes, starting 1 second after the injection of the enzyme in the well of the plate inside the plate reader.

\section{Note concerning the assumption that the number of detected photons per consumed substrate molecule is constant whatever the substrate concentration.}

As depicted in figure S3, the maximum measured light intensity is plotted versus initial substrate concentration we noticed that, for all the substrates studied, there is a signal intensity decrease at high concentration. We suggest the following three, not mutually exclusive, hypothesis to explain this observation. First, the substrate and reaction products absorb the light emission. Second, as for many enzymes, an excess of substrate inhibits the oxidation catalysis via an uncompetitive mechanism. Third, the photon emission occurring in the active site may be quenched by the excess of substrate present outside the active site. 

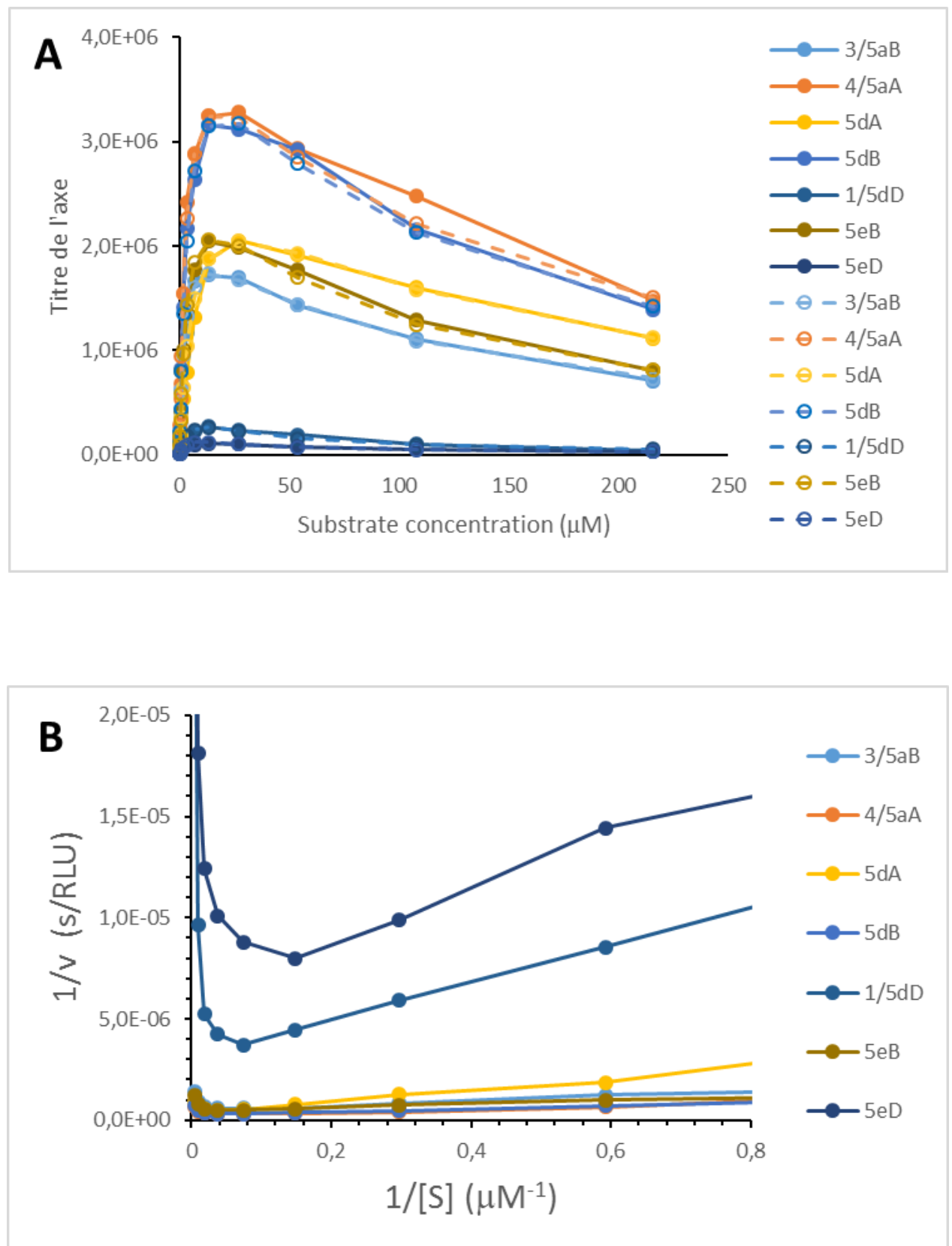

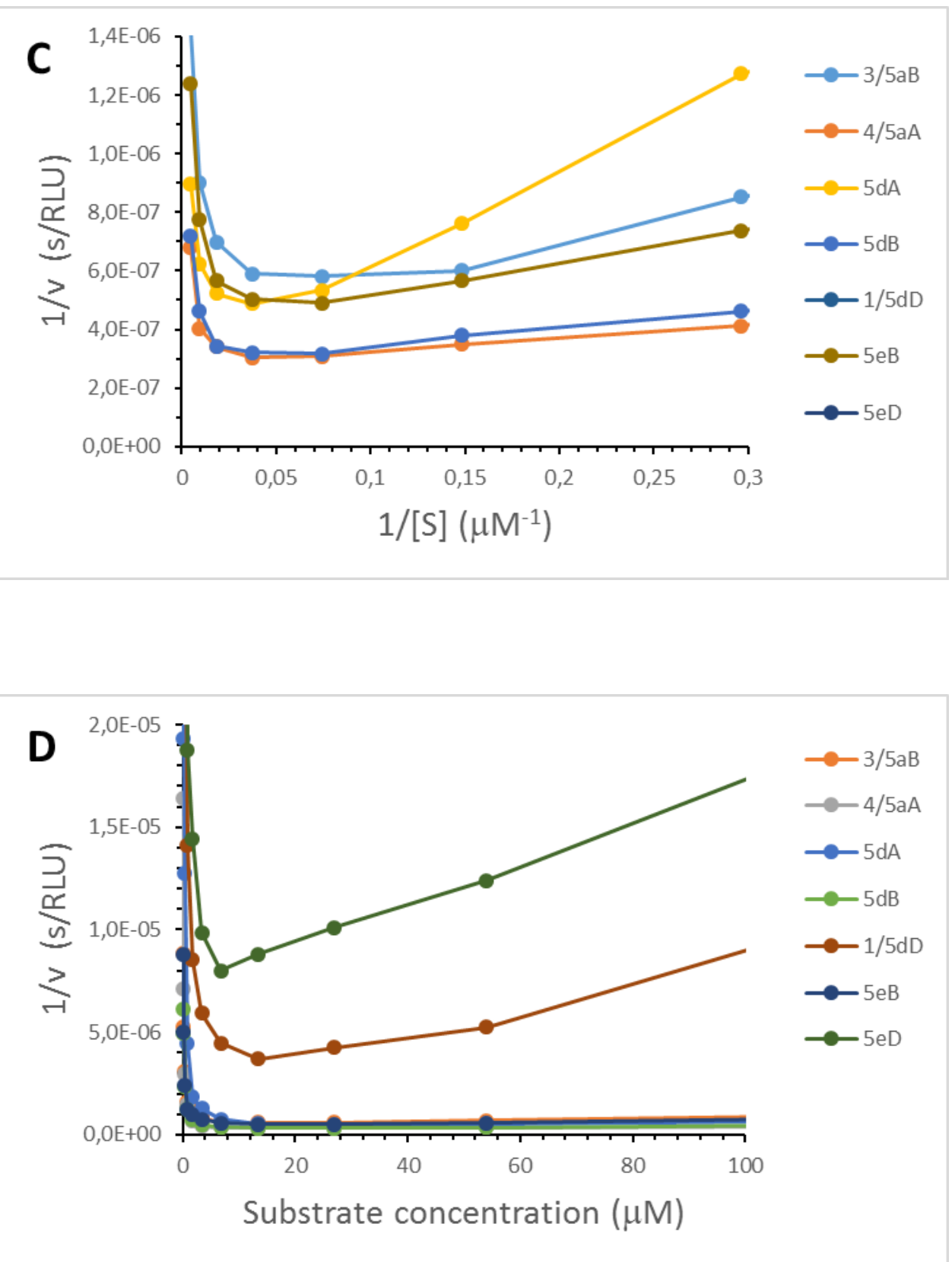


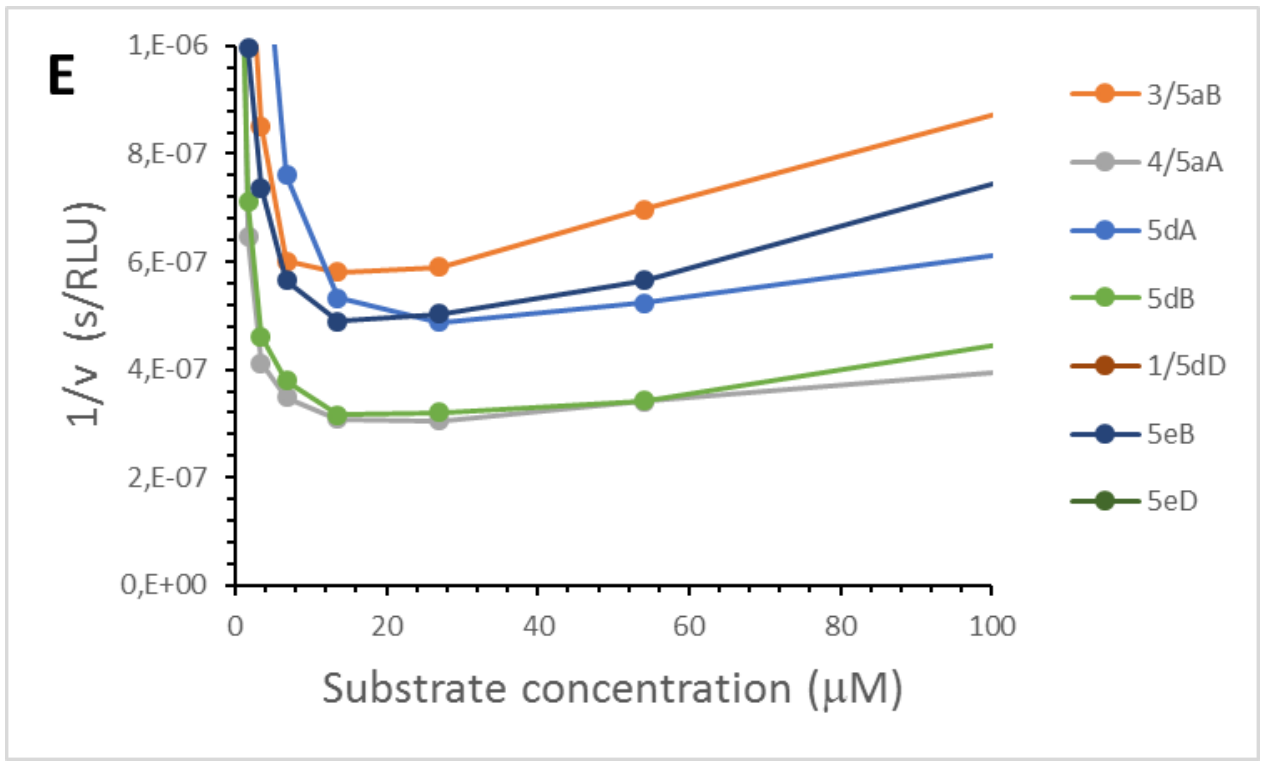

Figure S3. Maximal light intensity vs substrate concentration. (A) The maximal light intensity (RLU/s) is plotted in plain lines versus substrate concentrations $\left(10^{-6} \mathrm{M}\right)$ with the same enzyme concentration $\left(1.24 \cdot 10^{-12} \mathrm{M}\right)$. The kinetics fit with a Michaelis-Menten model (dashed lines). All substrates inhibit the detected light intensity, by extrapolation the initial reaction velocity $\mathrm{v}$, at high concentration, suggesting an uncompetitive inhibition by excess of substrate. (B, C) The Lineweaver-Burk plots of 1/v (1/Light intensity in s/RLU) versus $1 / \mathrm{S}\left(\mathrm{M}^{-1}\right)$ are shown with two scales. The curvature along the $1 / \mathrm{v}$ axis is characteristic of uncompetitive inhibition by substrate excess. The extrapolation of the linear part is intercepted by the $\mathrm{x}$-axis at the $-1 / K^{\prime}{ }_{M}$ value, the inverse of the apparent Michaelis constant, and by the $y$-axis at the $1 / \mathrm{V}^{\prime}{ }_{\max }$. (D,E) In the same plots shown with two scales of $1 / \mathrm{v}$ versus $S$, the extrapolation of the linear part is intercepted by the $\mathrm{x}$-axis at the $K_{I}$ value, the dissociation constant of the second substrate molecule from the complex ES. 


\section{Light absorption of all the substrates}

Concerning the first hypothesis to explain this signal intensity decrease at high concentration, we measured the substrates absorption characteristics between 400 and $600 \mathrm{~nm}$ (table S1).

\begin{tabular}{|c|c|c|c|c|c|c|c|}
\hline Luciferins & $3 / 5 \mathbf{a B}$ & $4 / 5 \mathbf{a A}$ & $5 \mathrm{dA}$ & $5 \mathrm{~dB}$ & $1 / 5 \mathrm{dD}$ & $5 \mathrm{eB}$ & $5 \mathrm{eD}$ \\
\hline$\square_{\max }(\mathbf{n m})$ & 413 & 426 & 426 & 418 & 426 & 412 & 418 \\
\hline$\square \max \left(\mathbf{M}^{-1} \mathbf{c m}^{-1}\right)$ & 6294 & 7881 & 6973 & 7754 & 8950 & 6415 & 7692 \\
\hline$\square_{440} \mathrm{~nm}\left(\mathrm{M}^{-1} \mathrm{~cm}^{-1}\right)$ & 5010 & 7453 & 6594 & 6811 & 8326 & 5013 & 6496 \\
\hline$\square_{450} \mathrm{~nm}\left(\mathrm{M}^{-1} \mathrm{~cm}^{-1}\right)$ & 3946 & 6715 & 5779 & 5633 & 7137 & 4003 & 5244 \\
\hline$\square 460 \mathrm{~nm}\left(\mathrm{M}^{-1} \mathrm{~cm}^{-1}\right)$ & 2964 & 5832 & 4781 & 4409 & 5734 & 3050 & 3981 \\
\hline$\square_{440-460} \mathrm{~nm}\left(\mathrm{M}^{-1} \mathrm{~cm}^{-1}\right)$ & 3974 & 6666 & 5718 & 5618 & 7066 & 4022 & 5240 \\
\hline
\end{tabular}

The light emissions observed with these substrates peak is between $440-460 \mathrm{~nm}$. The absorptions of these compounds in solution peak between 413 and $426 \mathrm{~nm}$ with averaged molar extinction coefficients $(\square)$ in between 440 and $460 \mathrm{~nm}$ of 3974 and $7066 \mathrm{M}^{-1} \mathrm{~cm}^{-1}$. At micromolar concentration, the absorption of light emitted by the substrate catalyzed oxidation is thus very weak in view of Beer-Lambert's law (emitted light intensity $=$ measured light intensity / $\mathrm{e}^{(\square \mathrm{Lc})}$ where $\mathrm{L}$ is the half height of the solution in the plate well (mm-range) and $\mathrm{c}$ the substrate concentration in the $10^{-6}-10^{-4} \mathrm{M}$ range). Accordingly, substrate absorption should contribute but is too weak to account for the loss of light observed beyond $27 \square \mathrm{M}$ of concentration for any tested substrate. 


\section{Kinetics analysis}

The apparent reaction rate ( $\left.\mathrm{v}^{\prime}\right)$ is given by the measured light intensity (RLU/s) reflecting counted photons/s, depending on the real catalytic rate $\left(k_{c a t}\right)$ and the yield of the measurement ( $\square$, the number of molecules catalyzed per RLU). The kinetics have been fitted using the MichaelisMentel model drawn below considering 1) the luciferins (S) as the limiting substrates and $\mathrm{O}_{2}$ as saturating substrate in the experimental assay conditions (100 $\square \mathrm{L})$ in a $6 \mathrm{~mm}$-diameter well of multi-well plates, 2) the inhibition of the enzyme E by excess of substrate through the binding of a second substrate (ESS) on the Michaelis' complex (ES) with the dissociation constant $K_{\mathrm{I}}$ and the on $\left(k_{S S, o n}\right)$ and off $\left(k_{S S, \text { off }}\right)$ binding constants, and 3$)$ the stochastic inactivation of the enzyme $\left(E^{*}\right)$ along the reaction turn over decreasing exponentially the active enzyme population with the kinetic constant $k_{\text {inact }} . K^{\prime}{ }_{M}$ is the apparent constant of Michaelis and $\mathrm{V}^{\prime}{ }_{\text {max }}$ the apparent maximal reaction velocity.

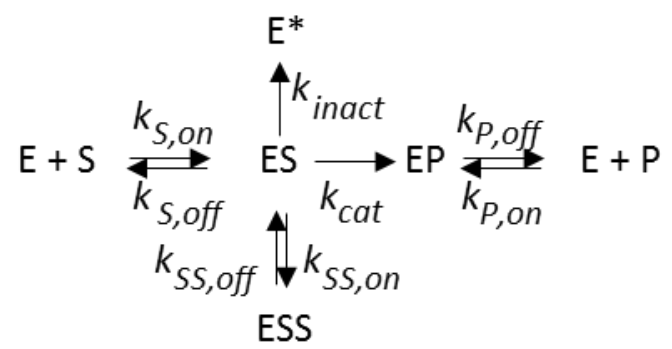

With

$$
\begin{aligned}
& \frac{d[E S]}{d t}=[E][S] k_{S_{i} \text { on }}-[E S] k_{S_{i} \text { off }}-[E S] k_{\text {cat }}-[E S][S] k_{S S_{i} \text { on }}+[E S S] k_{S S_{i} \text { off }}-[E S] k_{\text {inact }} \\
& K_{I}=\frac{k_{S S_{\text {off }}}}{k_{S S_{\text {on }}}}\left(\mathrm{mol} \mathrm{L}^{-1}\right) ; K_{M}=\frac{k_{S_{\text {s off }}}+k_{\text {cat }}}{k_{S_{i} \text { on }}}=\frac{K_{M}^{s}}{1+\frac{[S]^{2}}{K_{I}}}\left(\mathrm{~mol} \mathrm{~L}^{-1}\right) \\
& V_{\max }=\left[E_{0}\right][S] k_{\text {cat }}=V_{\max }^{s} \frac{[S]+K_{M}+\frac{[S]^{2}}{K_{I}}}{[S]}\left(\mathrm{mol} \mathrm{s}^{-1}\right) \\
& v^{\prime}=\frac{[E][S] k_{\text {cat }}}{[S]+K_{M}+\frac{[S]^{2}}{K_{I}}}\left(\mathrm{RLU} \mathrm{s}^{-1}\right)
\end{aligned}
$$




$$
[E]=\left[E_{0}\right] e^{-t \mathbb{R}_{\text {inart }} \text { with }} k_{\text {inoet }} \text { in s } s^{-1} \text { and the time } t \text { in s }
$$

$v=v^{\prime} \rho\left(\mathrm{mol} \mathrm{s}^{-1}\right)$ and $\rho=\frac{[S] N_{A} \text { vol }}{\Sigma I}$ (molecules. RLU $\left.{ }^{-1}\right), N_{A}=6.0210^{2 \mathrm{a}}$ and $v o l$ the volume $(\mathrm{L})$
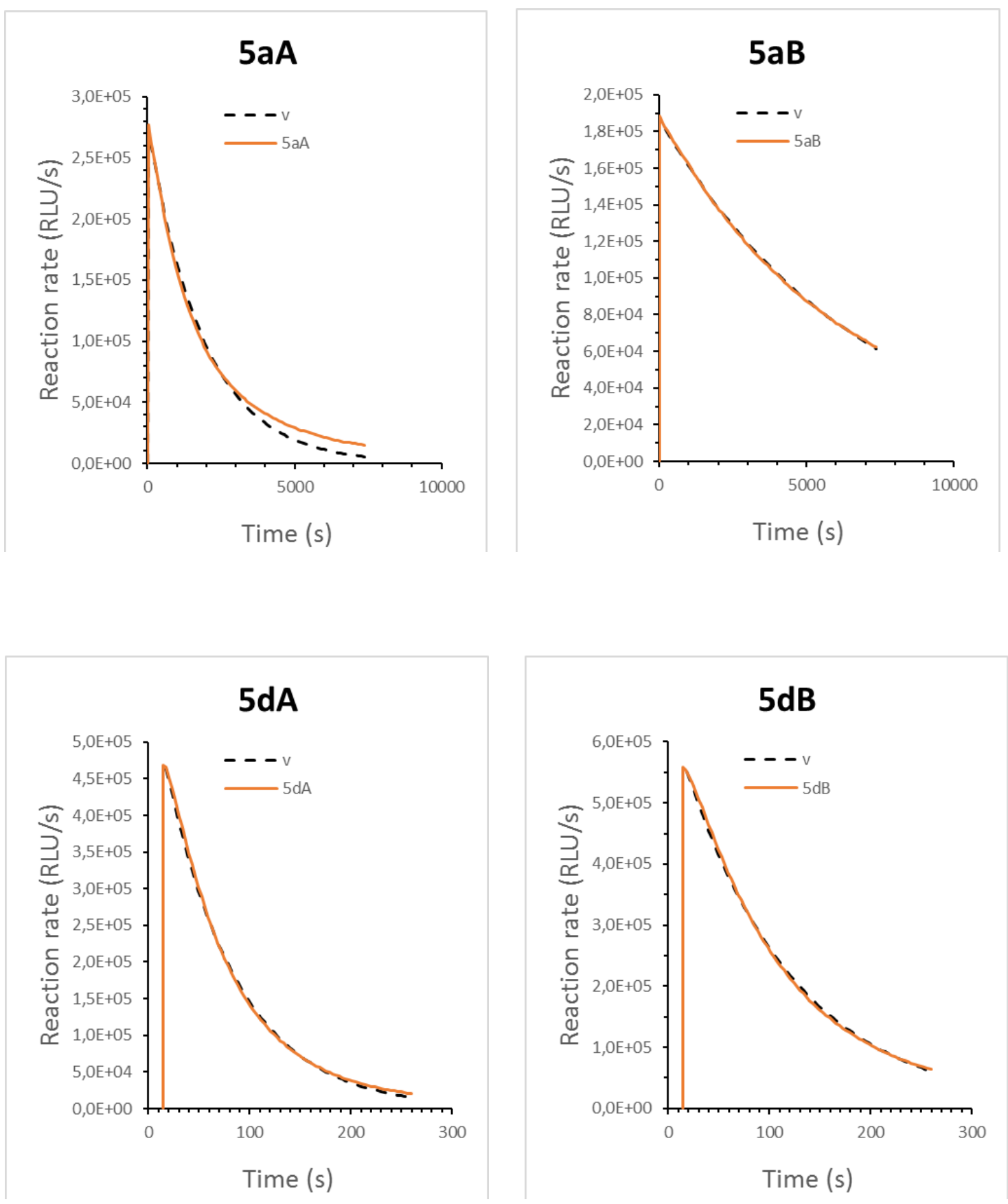

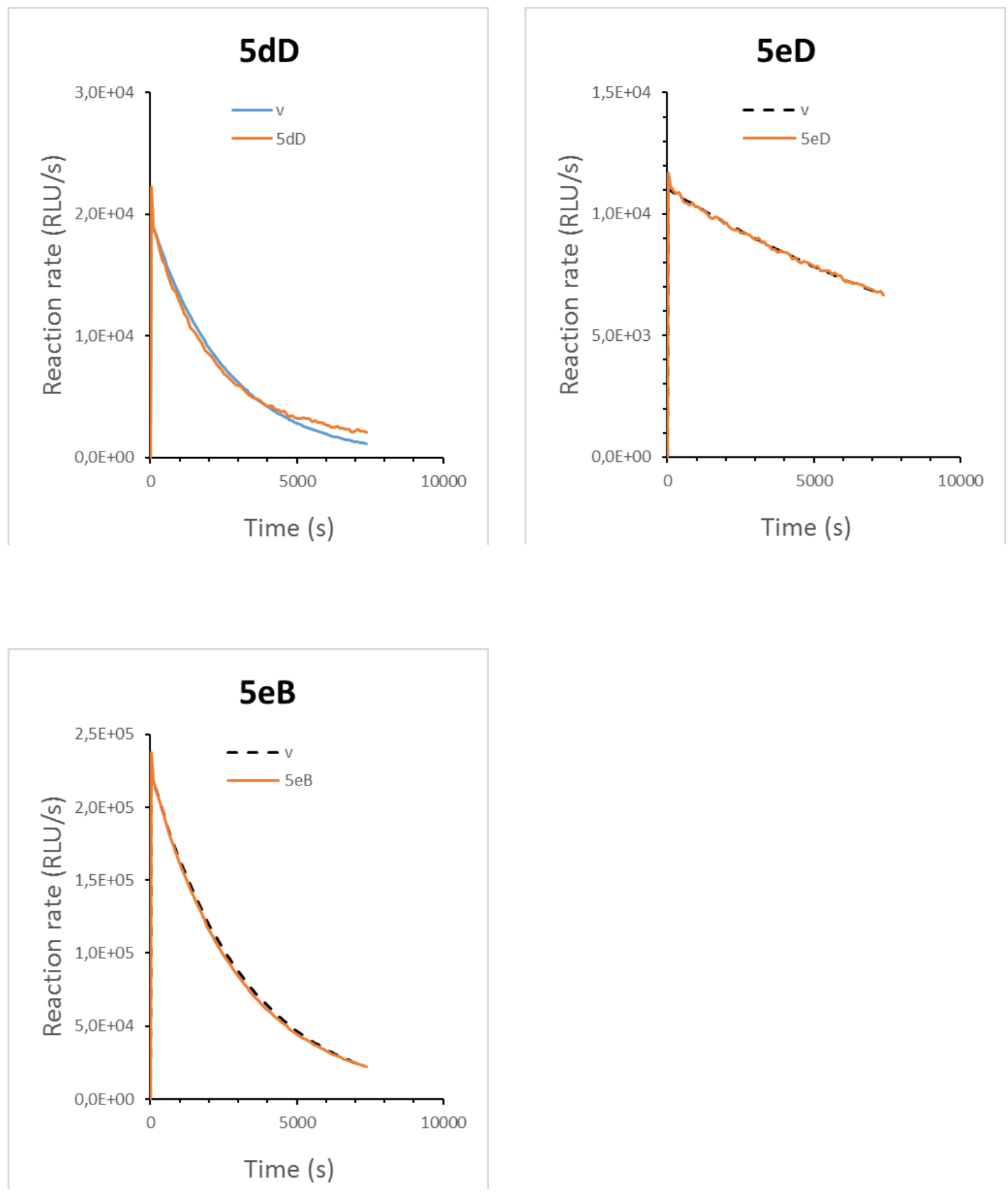

Figure S4: Enzyme inactivation kinetics. The kinetics are plotted versus time with the same enzyme concentration and the same substrate concentration. These plots compare the fitting of the experimental data (red plain line) with the theoretical reaction velocity computed according to the described Michaelis-Menten model taking into consideration the irreversible inactivation of the enzyme (dashed black lines). 
From these computations, the following kinetic parameters were obtained:

\begin{tabular}{lccccccc}
\hline & $\mathbf{3 / 5 a B}$ & $\mathbf{4 / 5 a A}$ & $\mathbf{5 d A}$ & $\mathbf{5 d B}$ & $\mathbf{1 / 5 d D}$ & $\mathbf{5 e B}$ & $\mathbf{5 e D}$ \\
\hline $\mathbf{I}_{\max }\left(10^{6} \mathrm{RLU} / \mathrm{s}\right)$ & 1.69 & 3.28 & 2.05 & 3.11 & 0.23 & 1.98 & 0.10 \\
$\mathbf{t}^{1 / 2}(\mathrm{~min})$ & 74.29 & 19.34 & 3.22 & 0.33 & 20.96 & 32.27 & 148 \\
$\boldsymbol{\Sigma} \mathbf{I}\left(10^{6} \mathrm{RLU} / \mathrm{s}\right)$ & 84.98 & 80.85 & 5.61 & 11.57 & 6.29 & 62.97 & 6.04 \\
$\boldsymbol{K}_{\boldsymbol{M}}\left(10^{-6} \mathrm{M}\right)$ & 3.40 & 2.33 & 3.71 & 3.45 & 8.8 & 4.23 & 7.02 \\
$\boldsymbol{k}_{\text {cat }}\left(10^{18} \mathrm{RLU} / \mathrm{s}\right)$ & 1.80 & 3.50 & 2.32 & 3.60 & 0.44 & 2.33 & 0.17 \\
molecules/RLU & 1775 & 4581 & 12067 & 4463 & 101169 & 1804 & 70020 \\
$\boldsymbol{K}_{\boldsymbol{I}}\left(10^{-6} \mathrm{M}\right)$ & 104.94 & 115.21 & 140.55 & 101.64 & 22.48 & 84.02 & 35.42 \\
$\boldsymbol{K}_{\boldsymbol{M}}\left(10^{-6} \mathrm{M}\right)$ & 2.22 & 3.02 & 5.90 & 3.88 & 6.80 & 3.30 & 2.94 \\
$\boldsymbol{k}_{\text {cat }}(\mathrm{mol} / \mathrm{s} \cdot \mathrm{mol} \mathrm{E})$ & 106 & 534 & 932 & 535 & 1500 & 140 & 362 \\
$\boldsymbol{k}_{\text {inact }}\left(10^{-4} \mathrm{~s}^{-1}\right)$ & 1.5 & 5.2 & 425 & 375 & 3.8 & 4.5 & 3.1
\end{tabular}

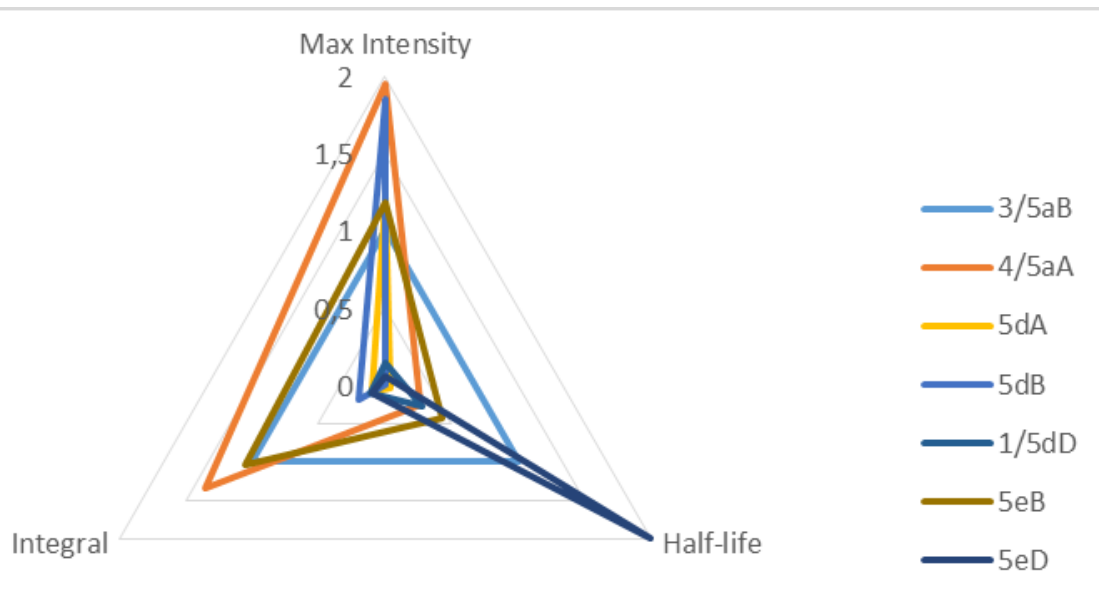

Plotting of the luciferase inactivation in the course of substrate catalyzed oxidation 
As depicted in figure S5, the light emission intensity decreases with time: steep for "flash" (5dB) and slow $(\mathbf{3 / 5 a B})$ for "glow" substrates. For verifying if the reaction rate indicated by the photon emission (RLU/s) decreases with time, the same enzyme amount $\left(62 \cdot 10^{-18} \mathrm{~mol}\right)$ was added when indicated by the arrows for different concentrations of substrates indicated in the legend between brackets $\left(10^{-6} \mathrm{M}\right)$. This demonstrates that enzyme is irreversibly inactivated during the kinetics as shown for luciferin $\mathbf{5 d B}$ an 3/aB.
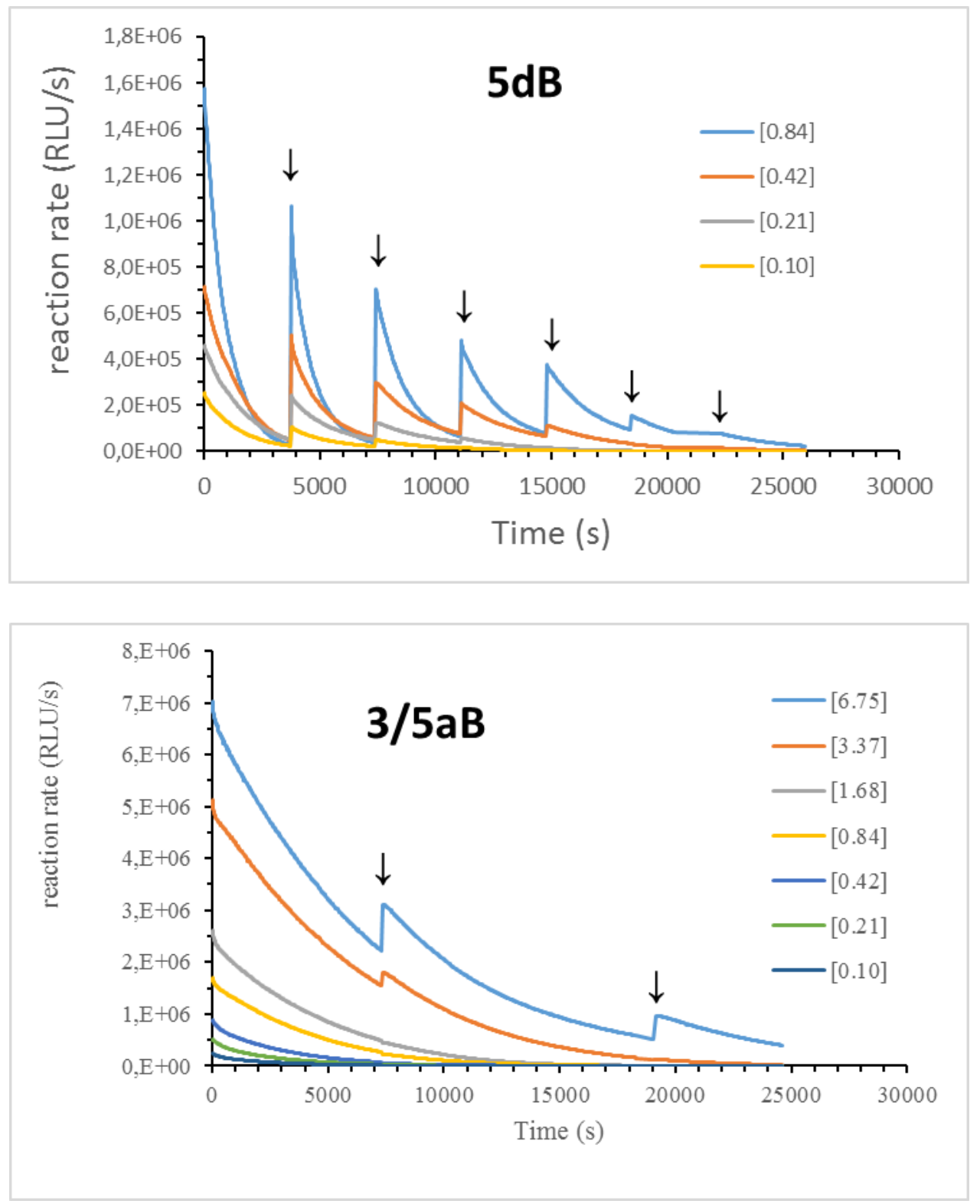
Figure S5. Luciferase inactivation in the course of the catalyzed oxidation of 5dB and 3/5aB. 


\section{References}

1. K. Tanaka, E. Yamamoto and N. Watanabe, US 20090082403, 2009.

2. A. Conte-Mayweg, H. Kuehne, T. Luebbers, C. Maugeais, W. Mueller and P. Pflieger, US 2006030613, 2006.

3. E. P. Coutant, V. Hervin, G. Gagnot, C. Ford, R. Baatallah and Y. L. Janin, Beilstein J. Org. Chem., 2018, 2853-2859.

4. G. Gagnot, V. Hervin, E. P. Coutant, S. Desmons, R. Baatallah, V. Monnot and Y. L. Janin, Beilstein J. Org. Chem., 2018, 14, 2846-2852.

5. S. Inouye, J. Sato, Y. Sahara-Miura, S. Yoshida, H. Kurakata and T. Hosoya, Biochem. Biophys. Res. Commun., 2013, 437, 23-28.

6. M. P. Hall, J. Unch, B. F. Binkowski, M. P. Valley, B. L. Butler, M. G. Wood, P. Otto, K. Zimmerman, G. Vidugiris, T. Machleidt, M. B. Robers, H. A. Benink, C. T. Eggers, M. R. Slater, P. L. Meisenheimer, D. H. Klaubert, F. Fan, L. P. Encell and K. V. Wood, ACS Chem. Biol., 2012, 7, 1848-1857.

7. $\quad$ S. C. Gill and P. H. von Hippel, Anal. Biochem., 1989, 182, 319-326. 


\section{${ }^{1} \mathrm{H}$ and ${ }^{13} \mathrm{C}$ spectra}

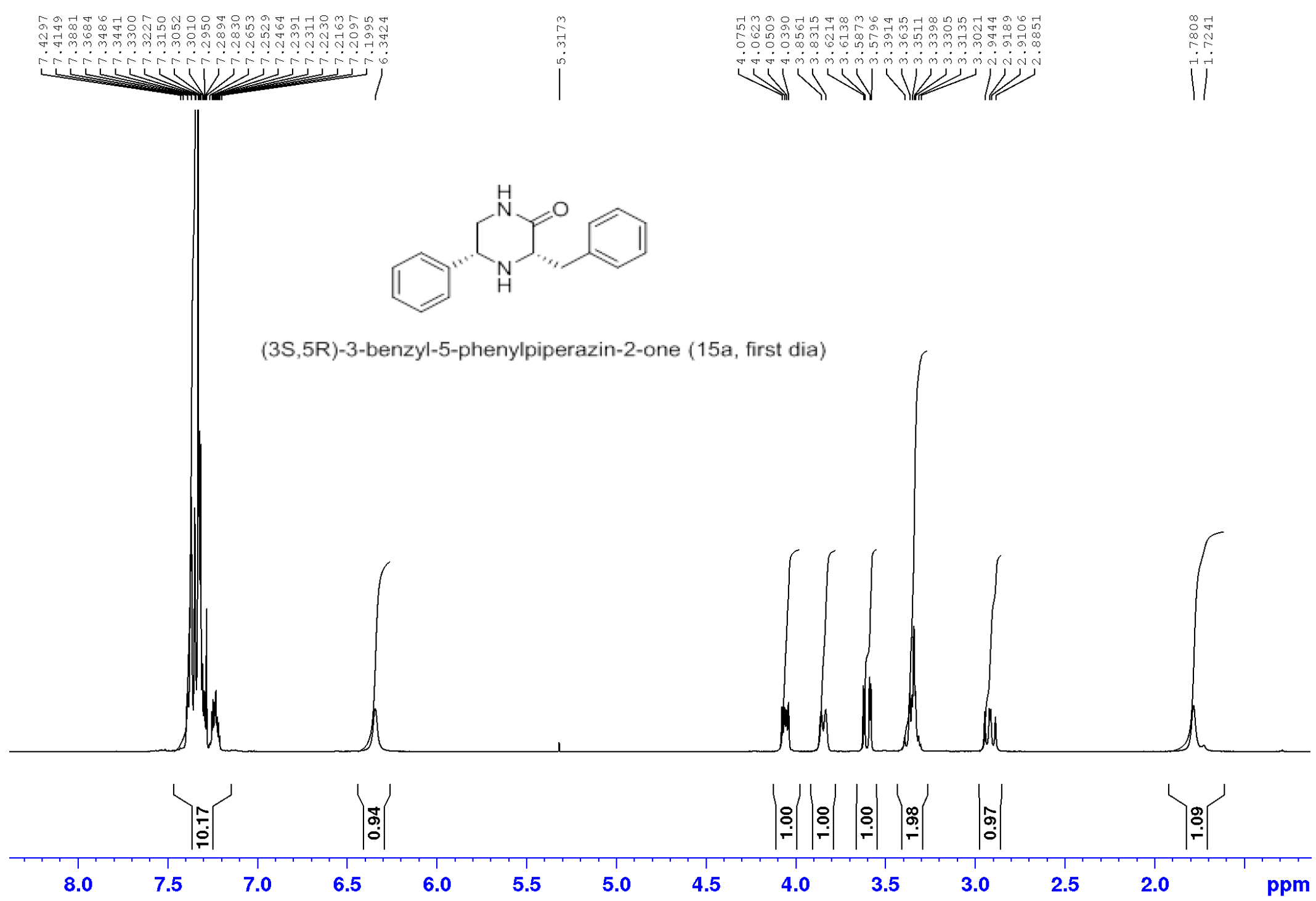


(3S,5R)-3-benzyl-5-phenylpiperazin-2-one (15a, first dia)

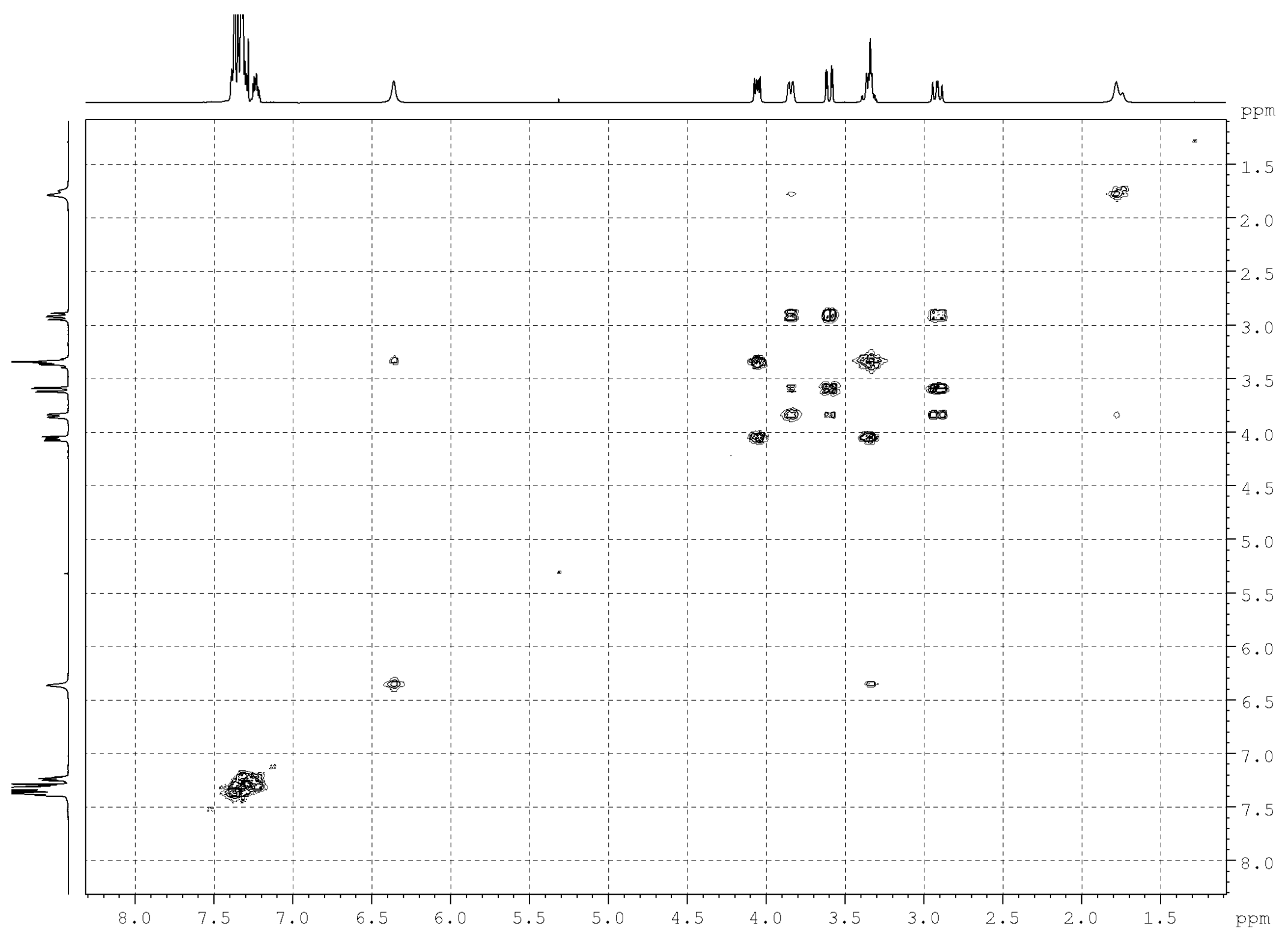









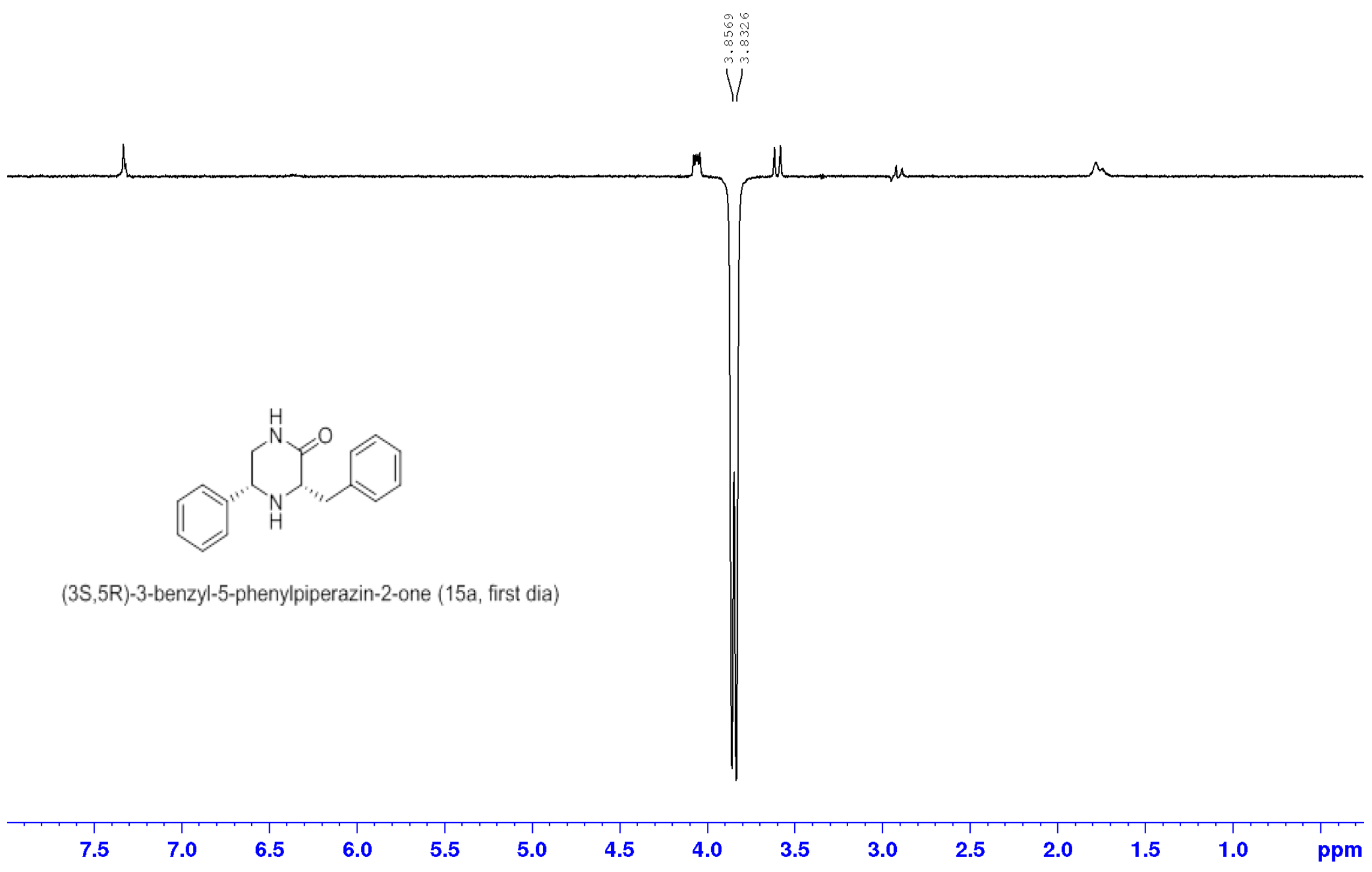




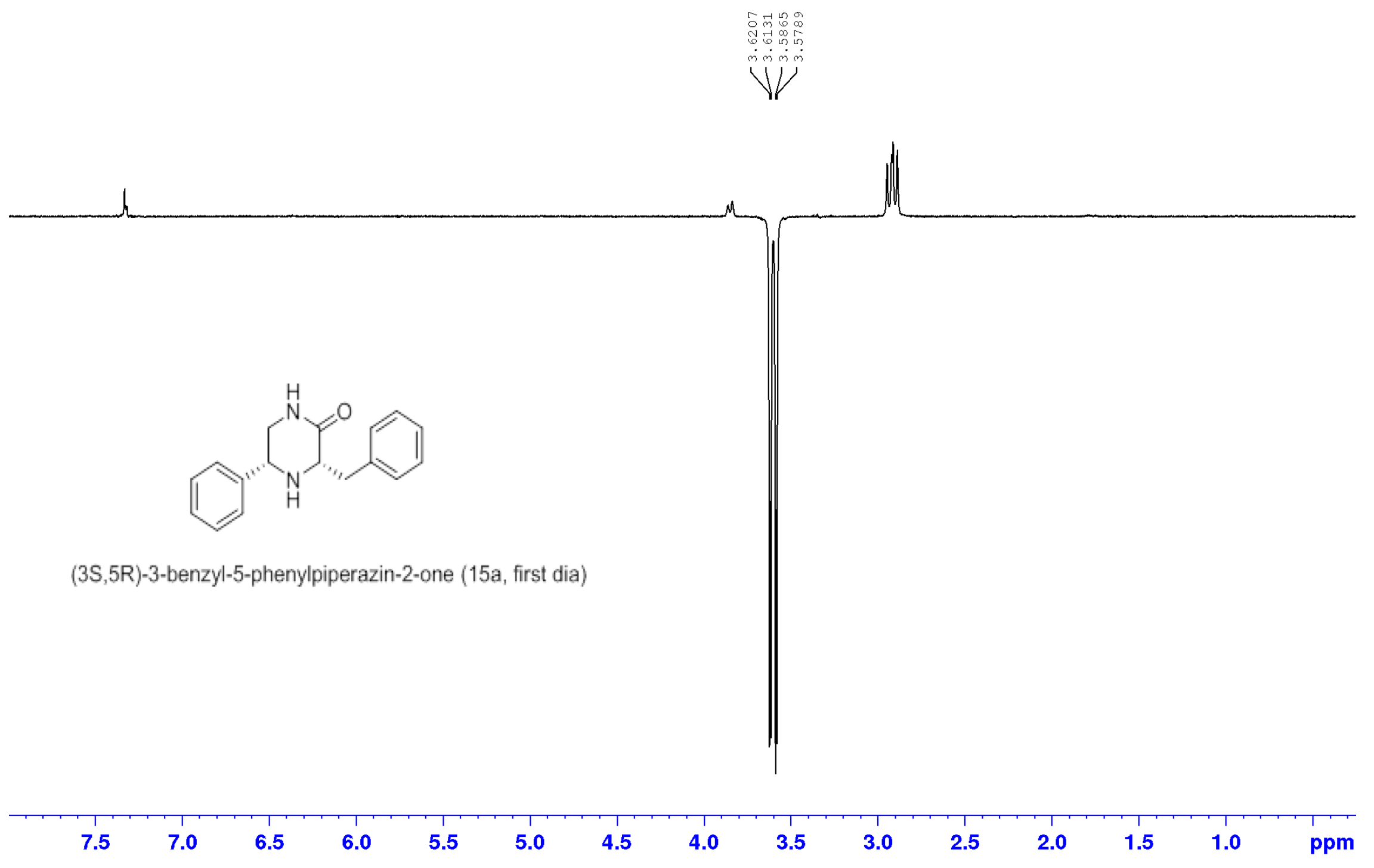



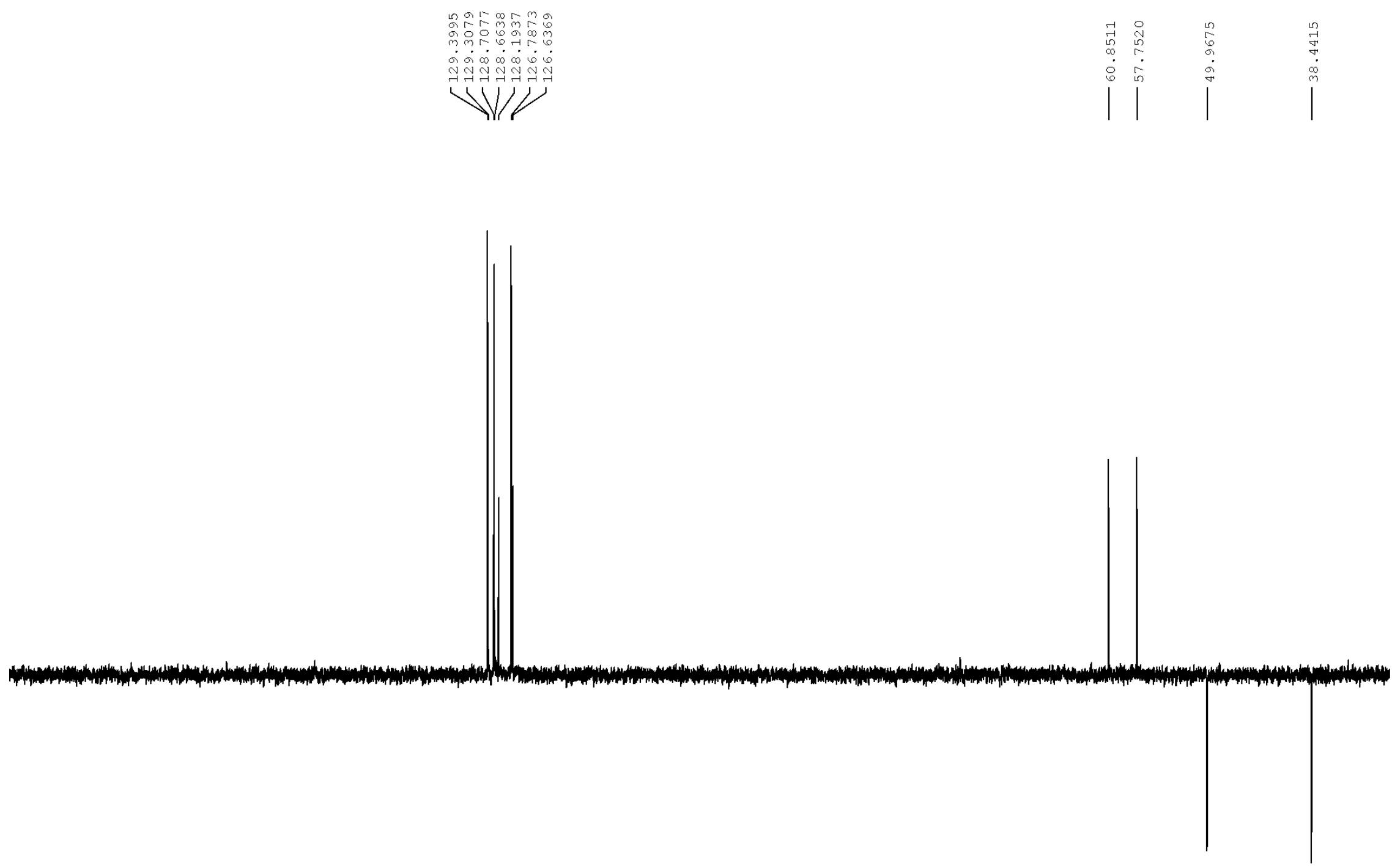

$\begin{array}{lllllllllllllllll}180 & 170 & 160 & 150 & 140 & 130 & 120 & 110 & 100 & 90 & 80 & 70 & 60 & 50 & 40 & \mathrm{ppm}\end{array}$


(3S,5R)-3-benzyl-5-phenylpiperazin-2-one (15a, first dia)

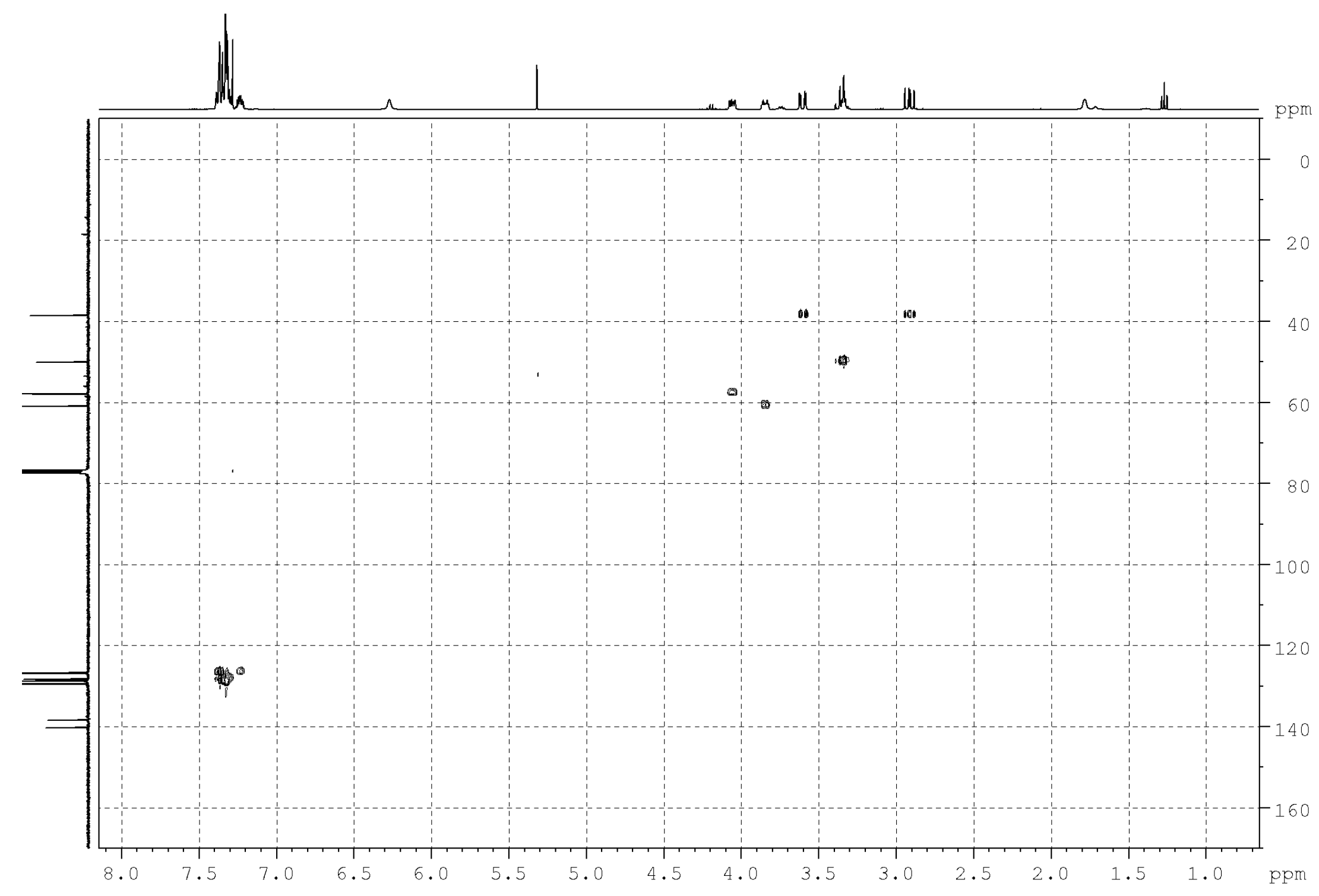



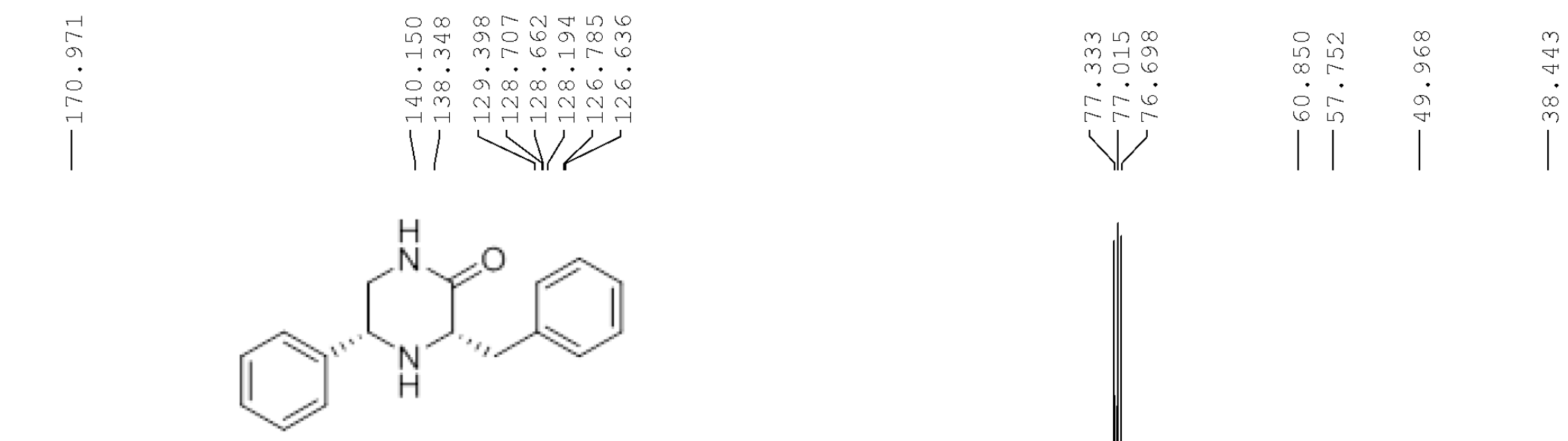

(3S,5R)-3-benzyl-5-phenylpiperazin-2-one (15a, first dia)

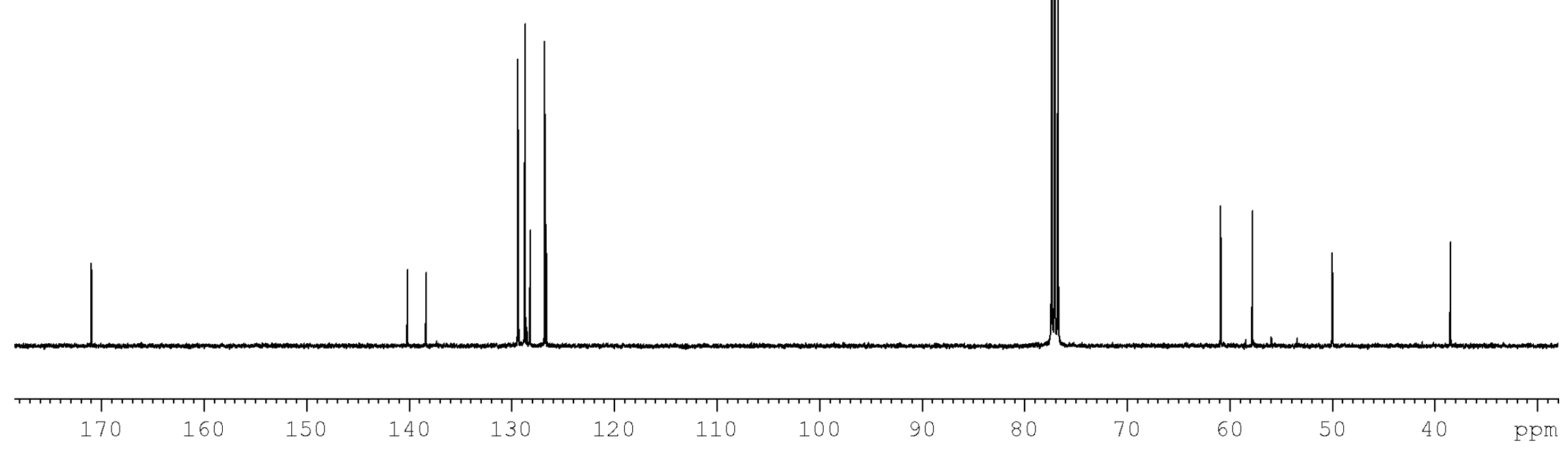






(3S,5S)-3-benzyl-5-phenylpiperazin-2-one (15a, second dia) 


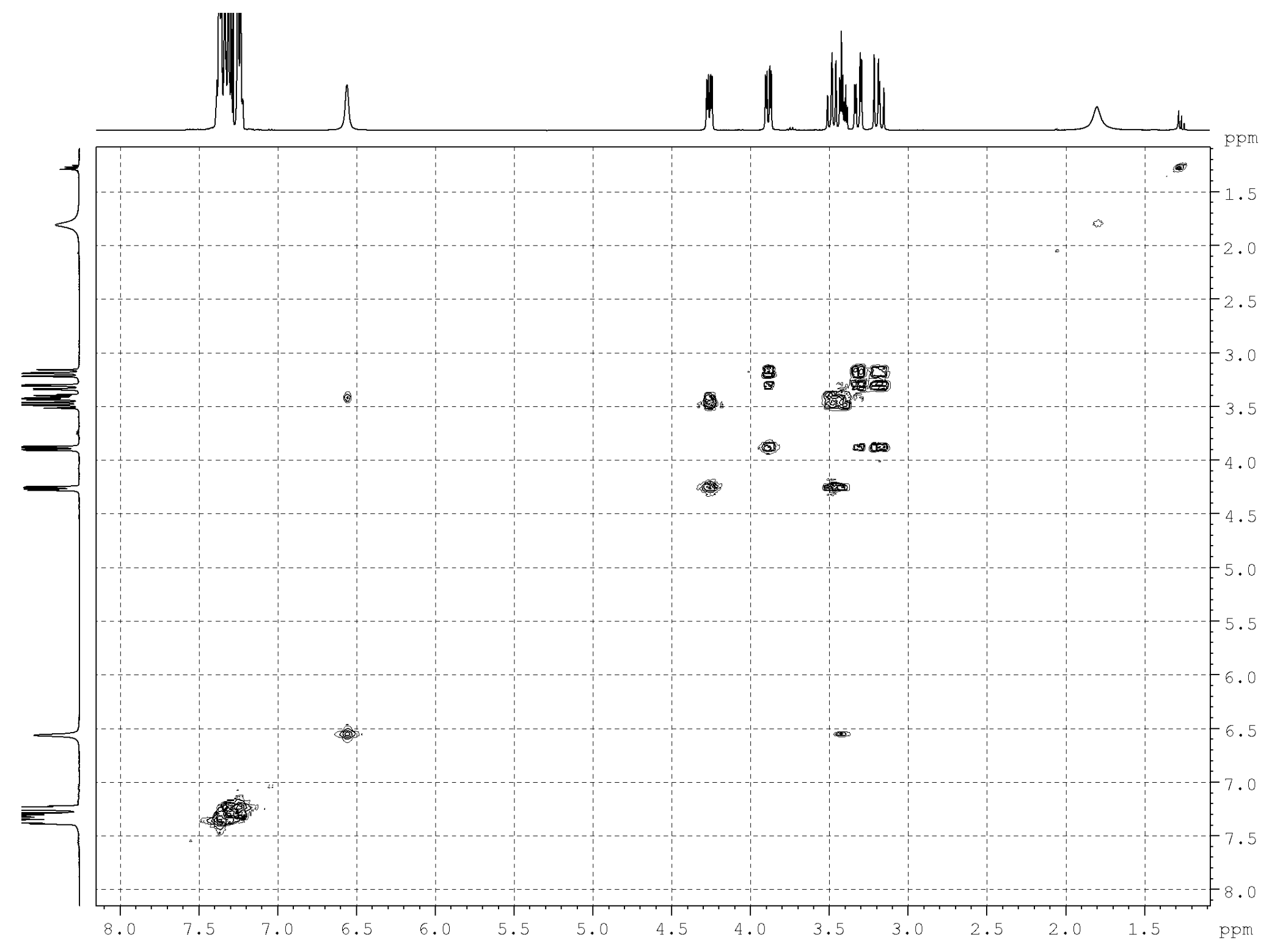




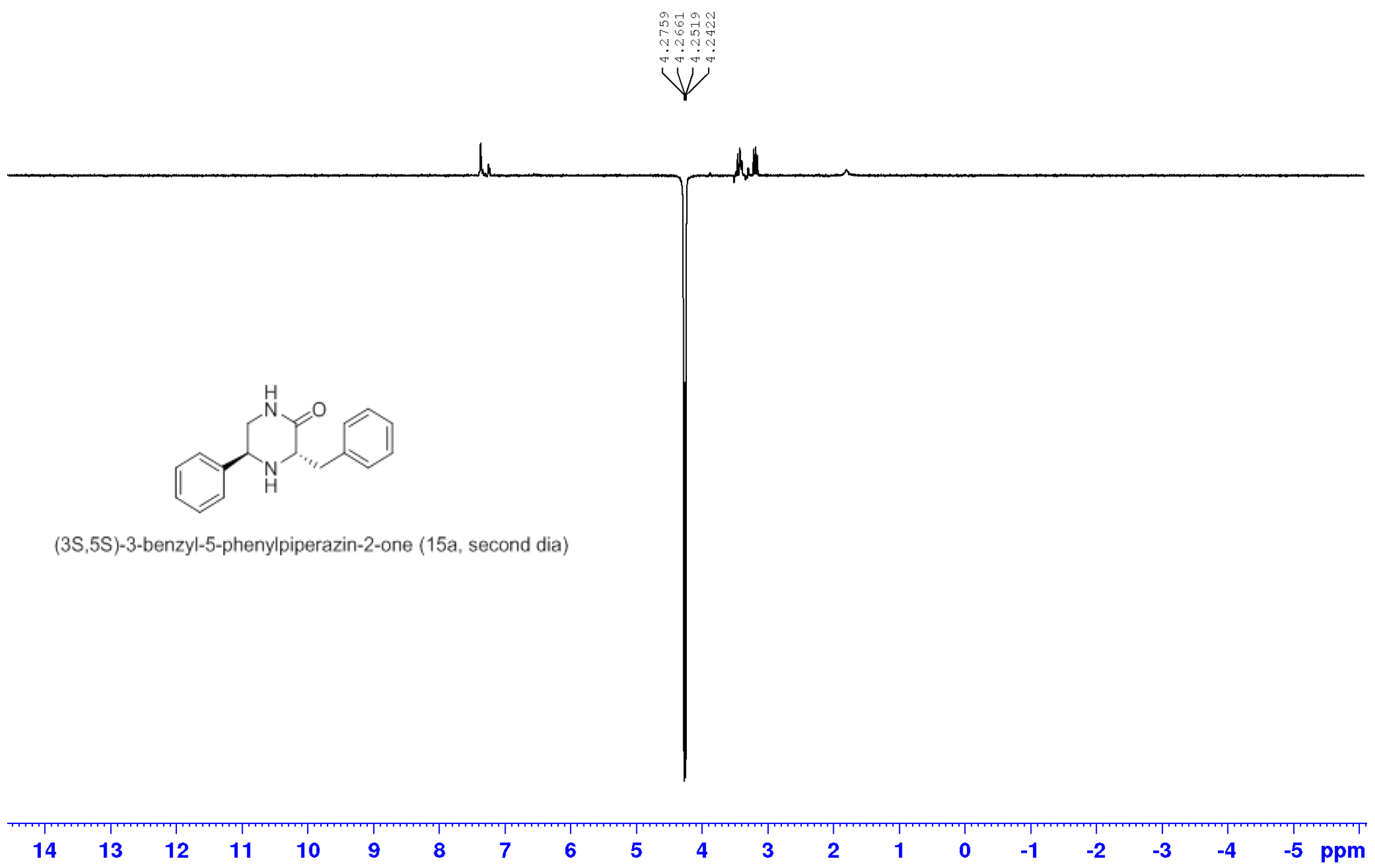






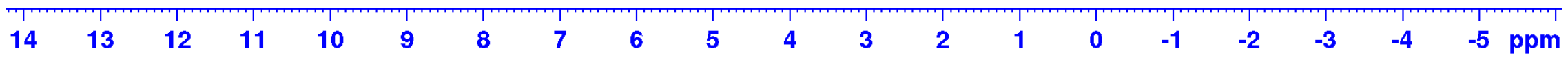

61 

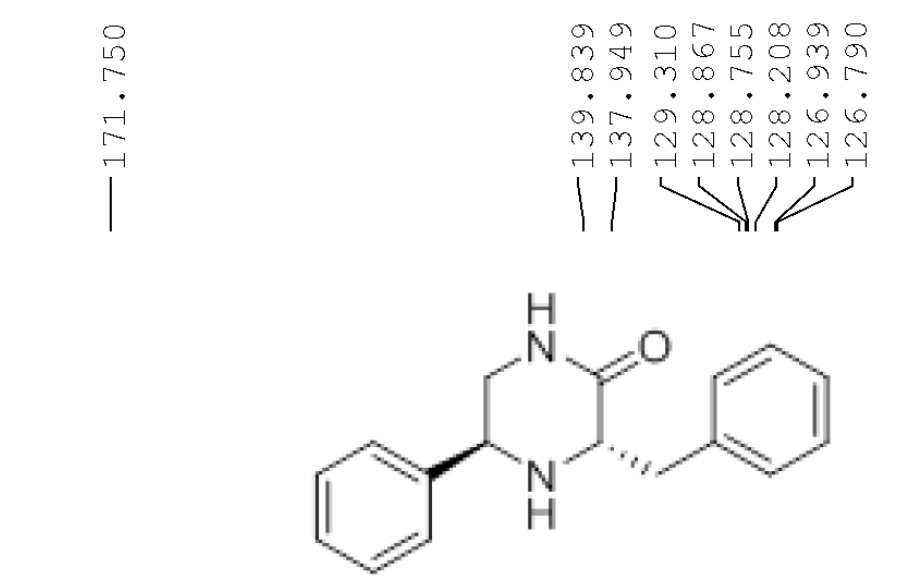

(3S,5S)-3-benzyl-5-phenylpiperazin-2-one (15a, second dia)

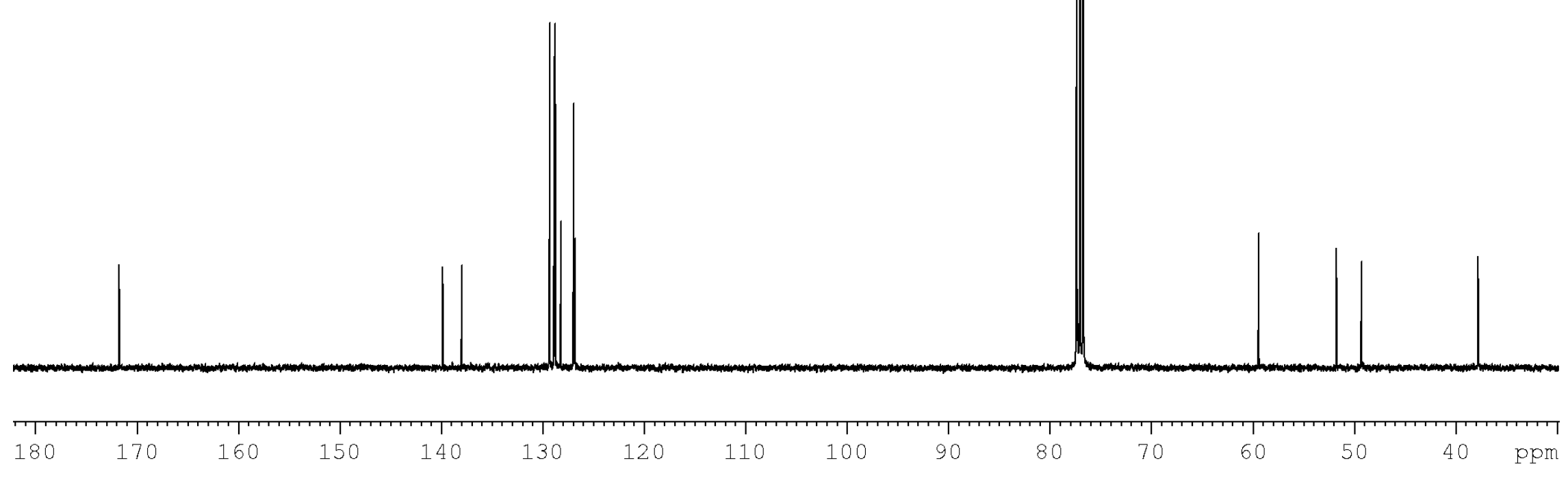




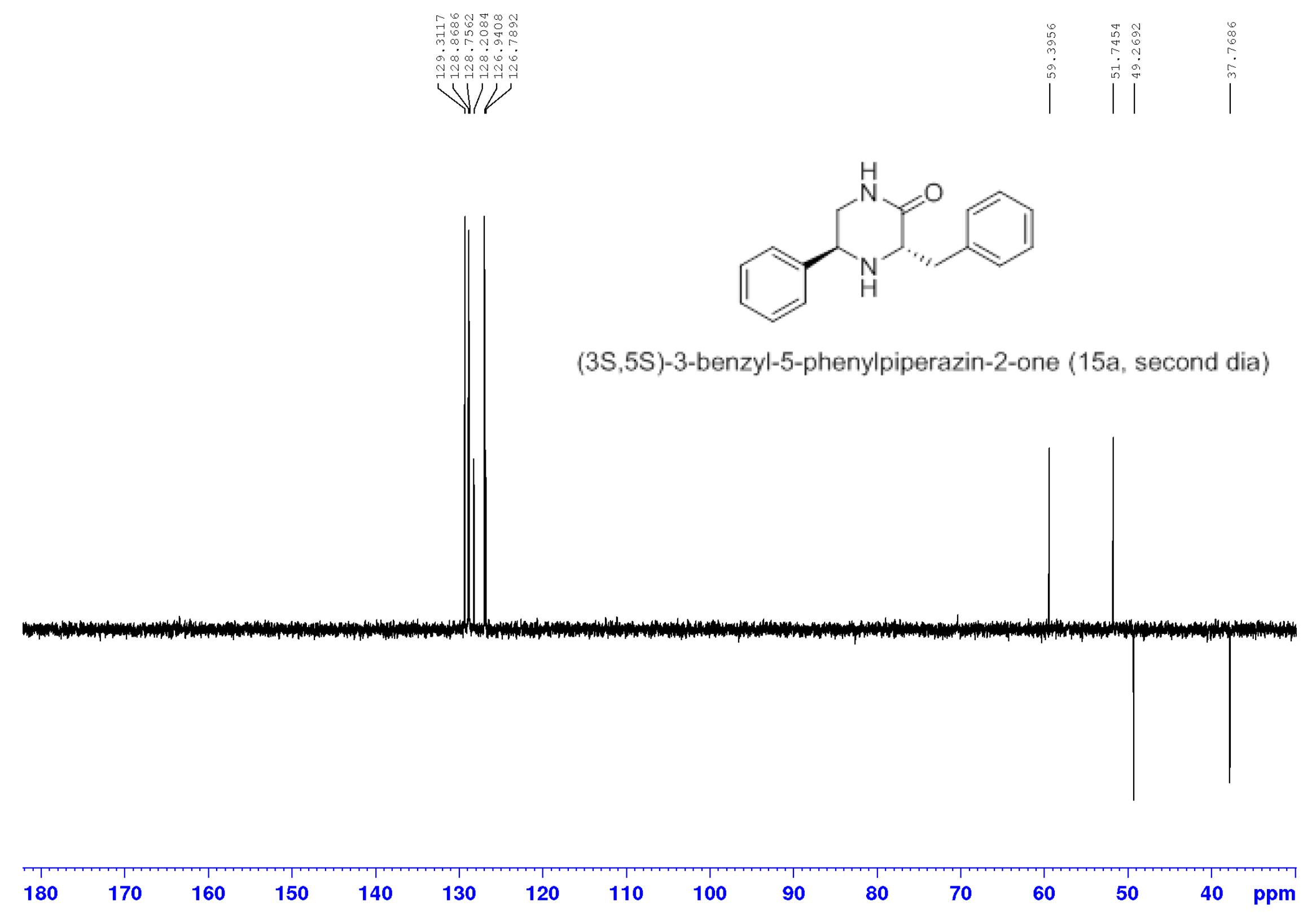


(3S,5S)-3-benzyl-5-phenylpiperazin-2-one (15a, second dia)

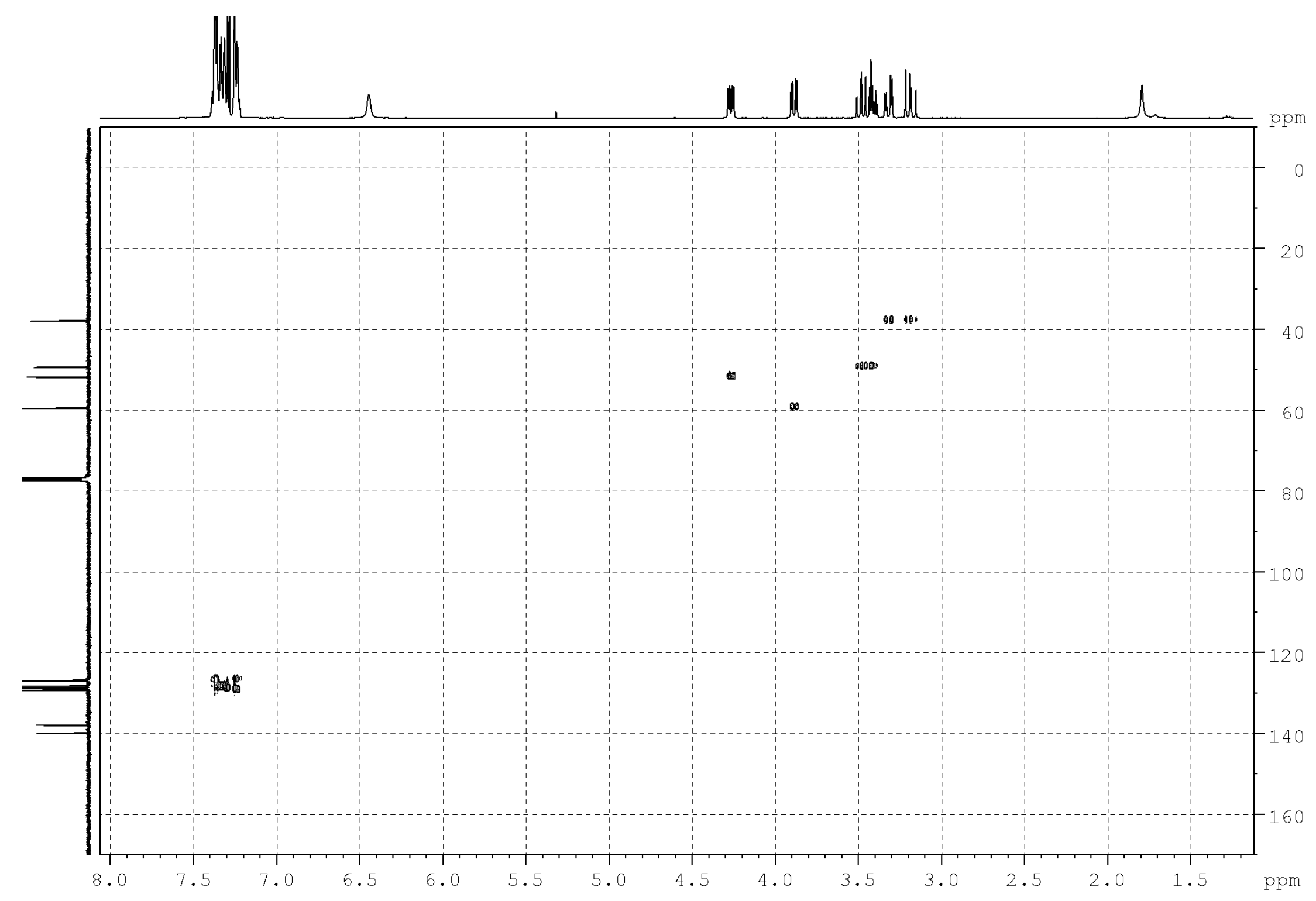




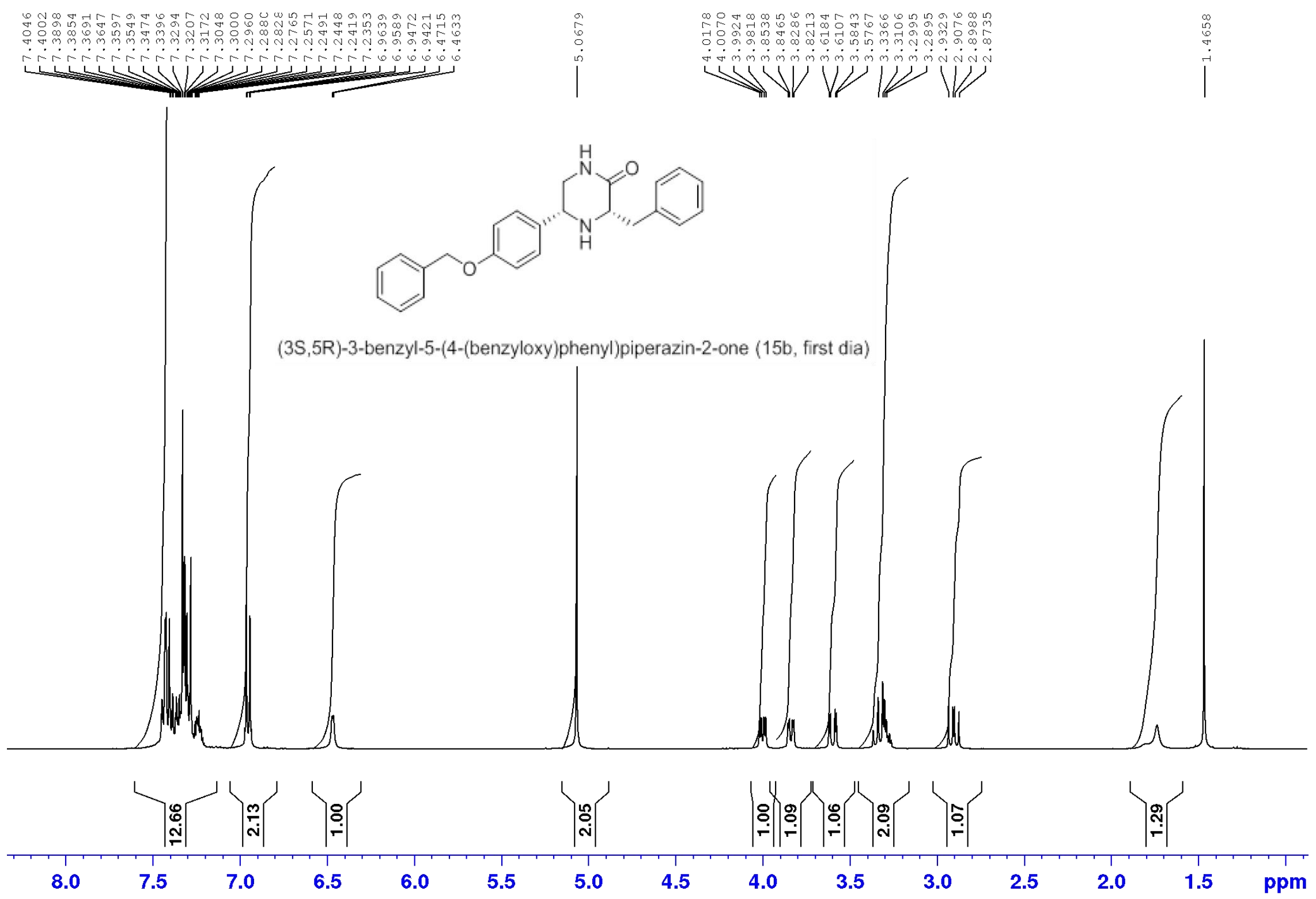





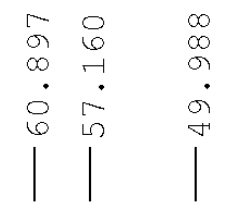

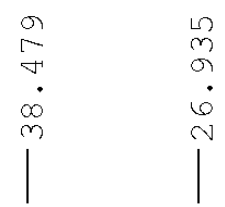
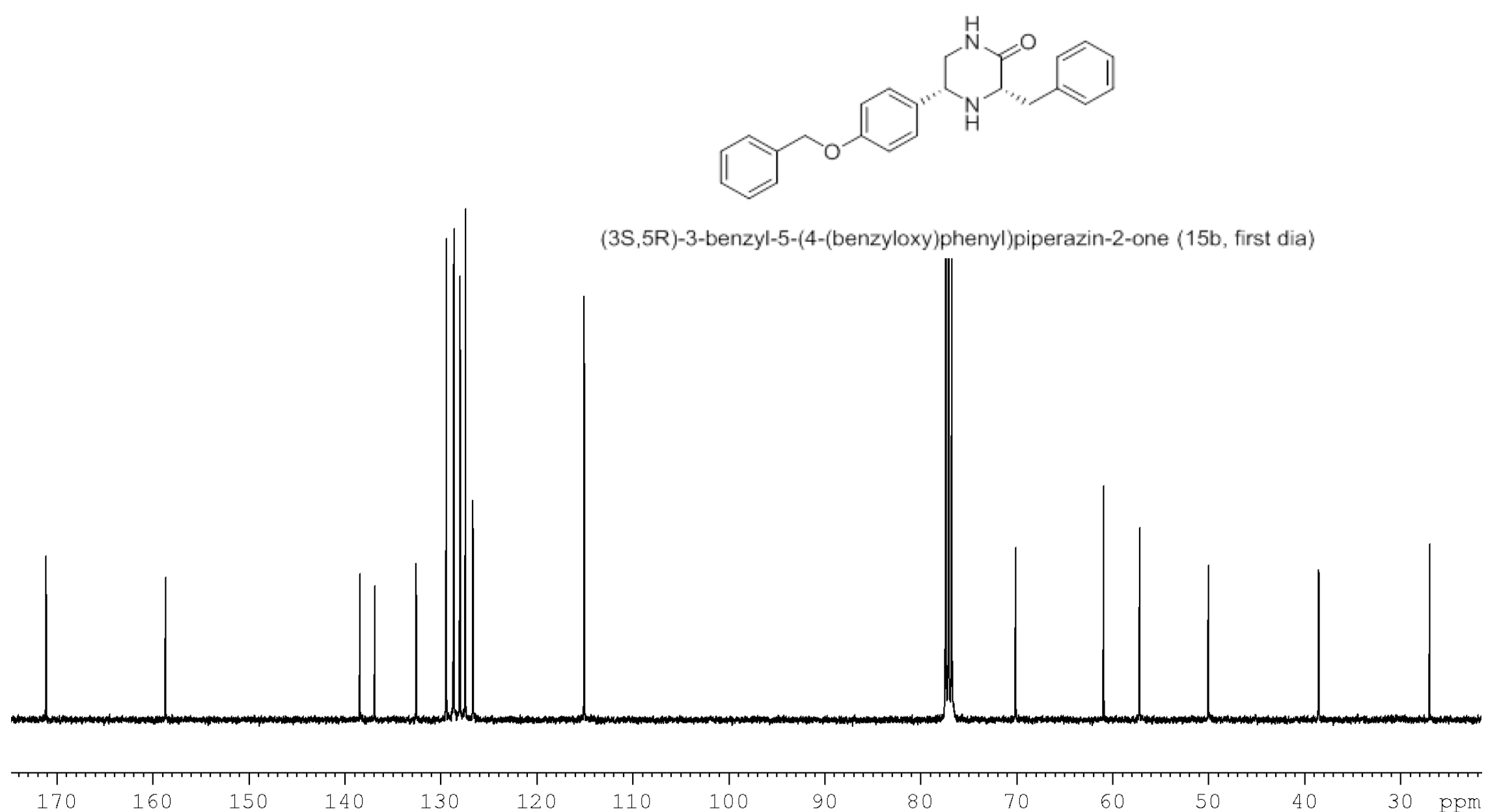









(3S,5S)-3-benzyl-5-(4-(benzyloxy)phenyl)piperazin-2-one (15b, second dia)

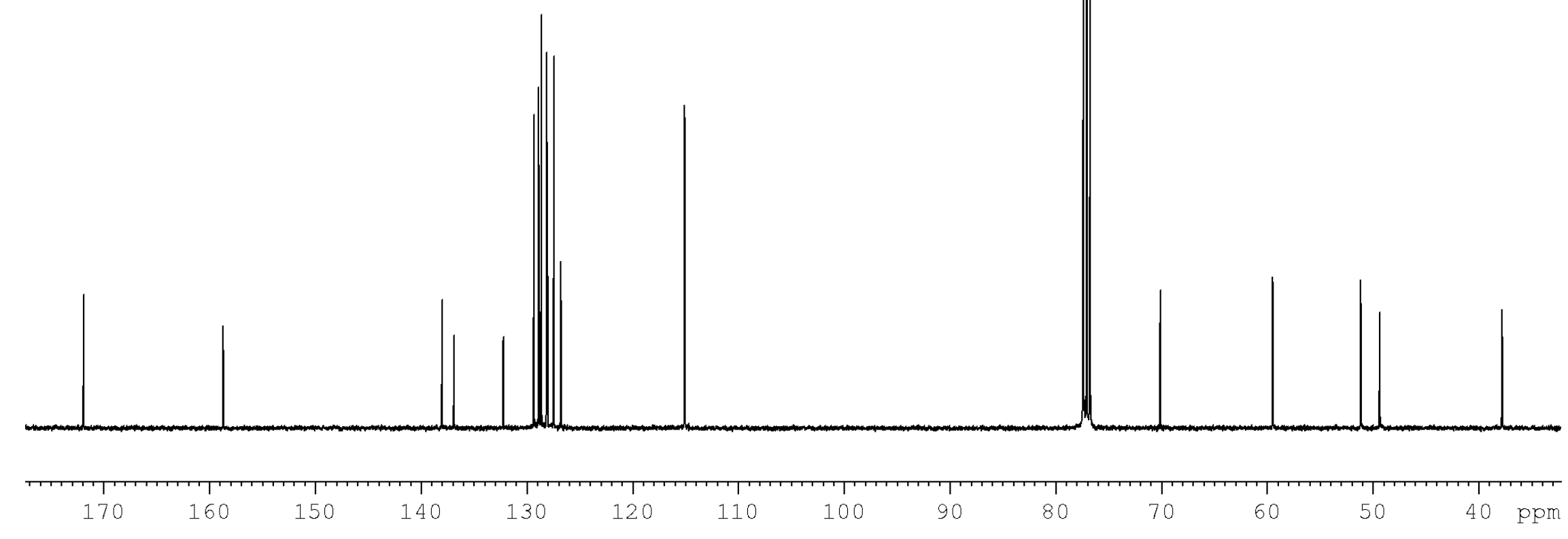




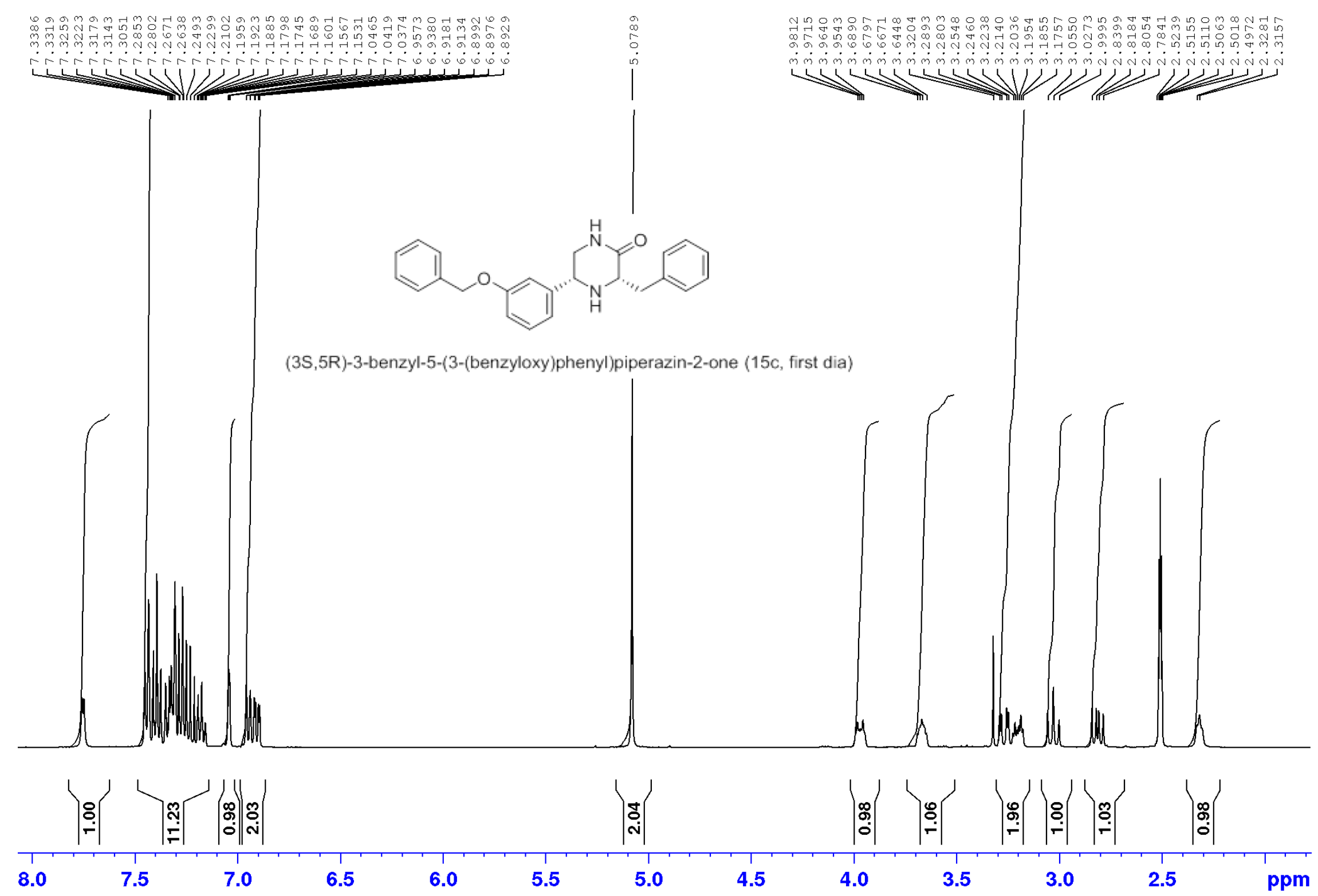




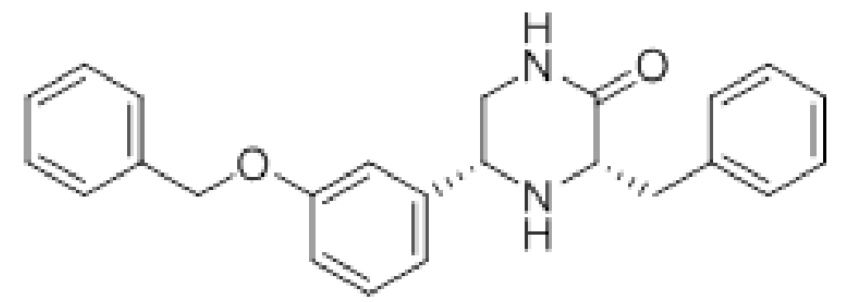

(3S,5R)-3-benzyl-5-(3-(benzyloxy)phenyl)piperazin-2-one (15c, first dia)

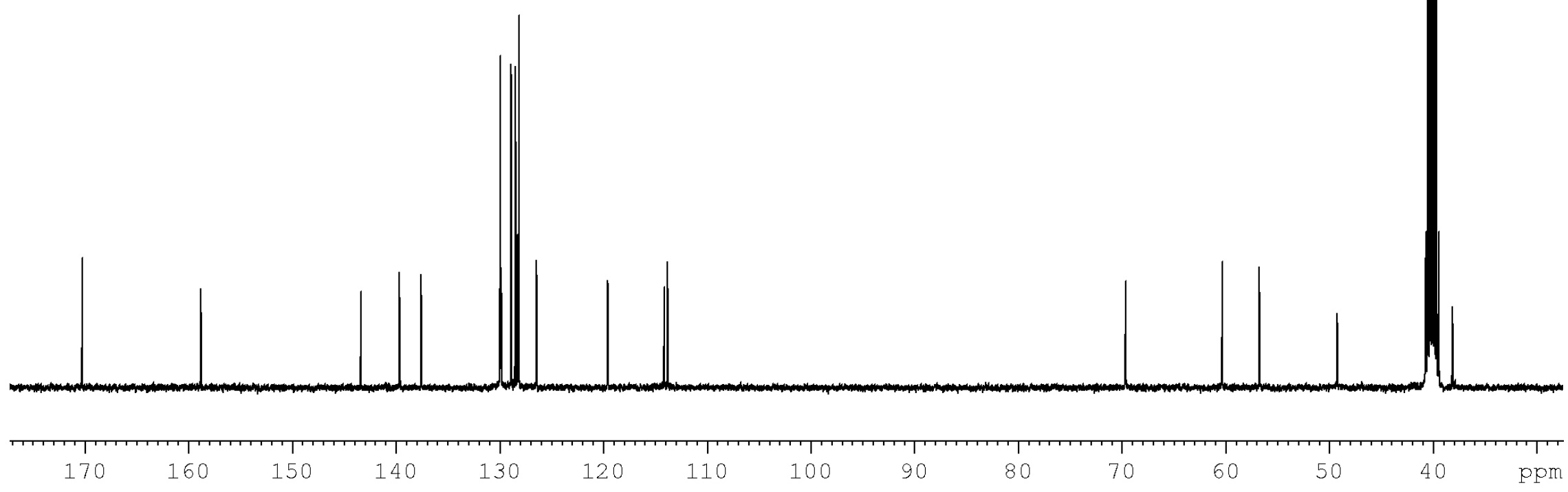








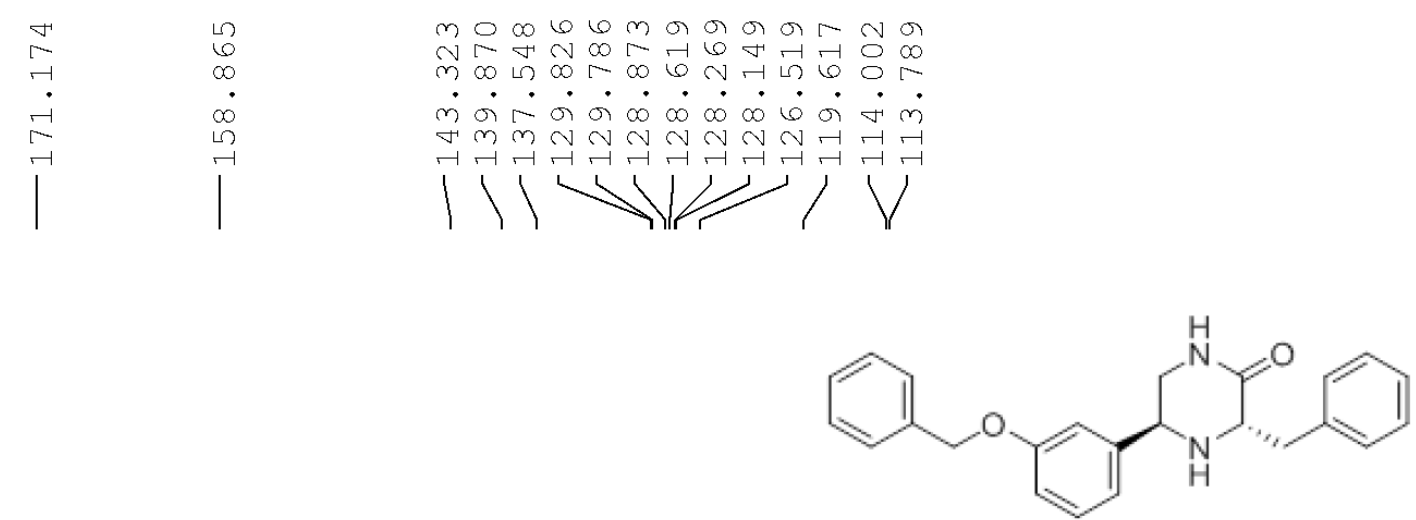

(3S,5S)-3-benzyl-5-(3-(benzyloxy)phenyl)piperazin-2-one (15c, second dia)







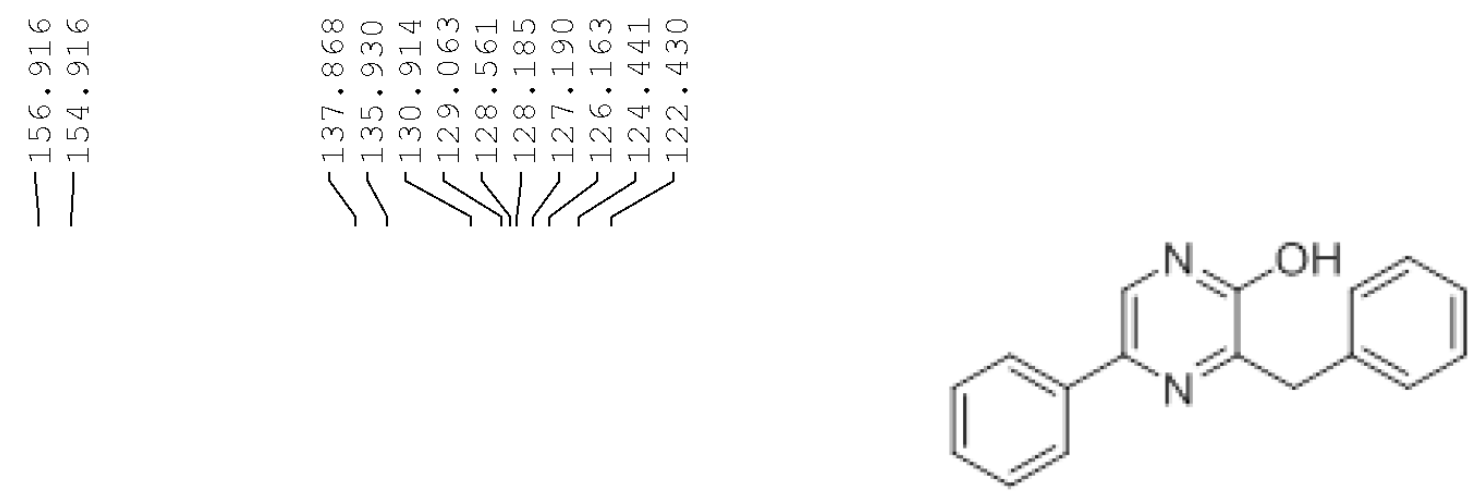

3-Benzyl-5-phenylpyrazin-2-ol (16a)

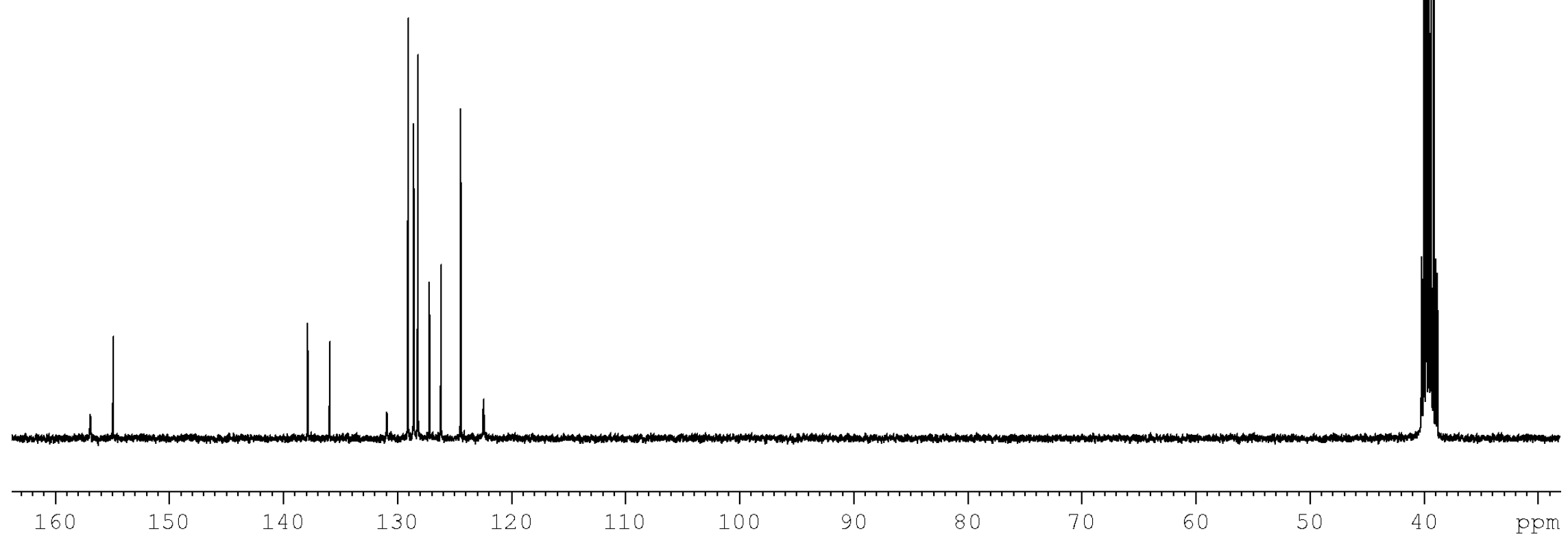




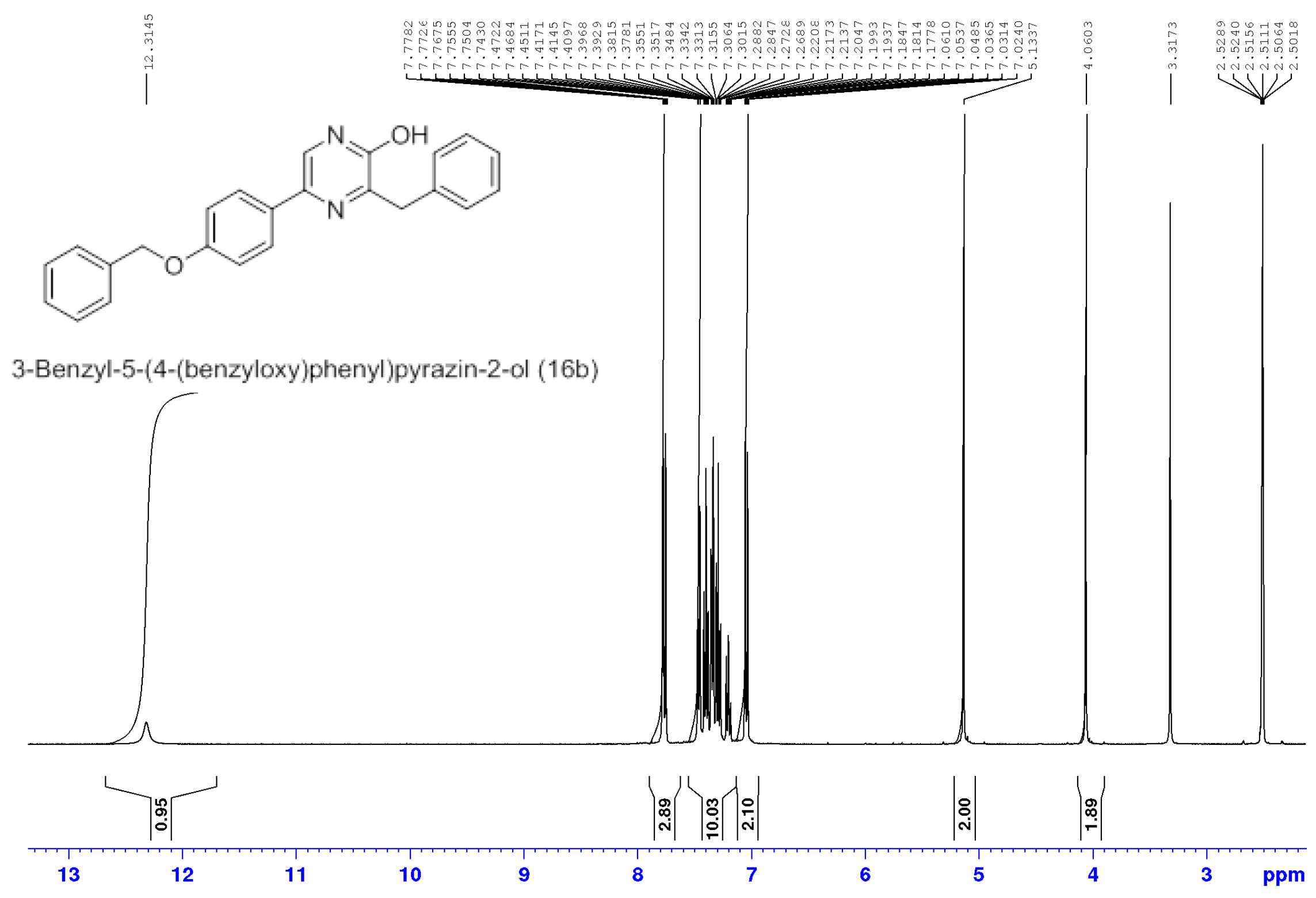




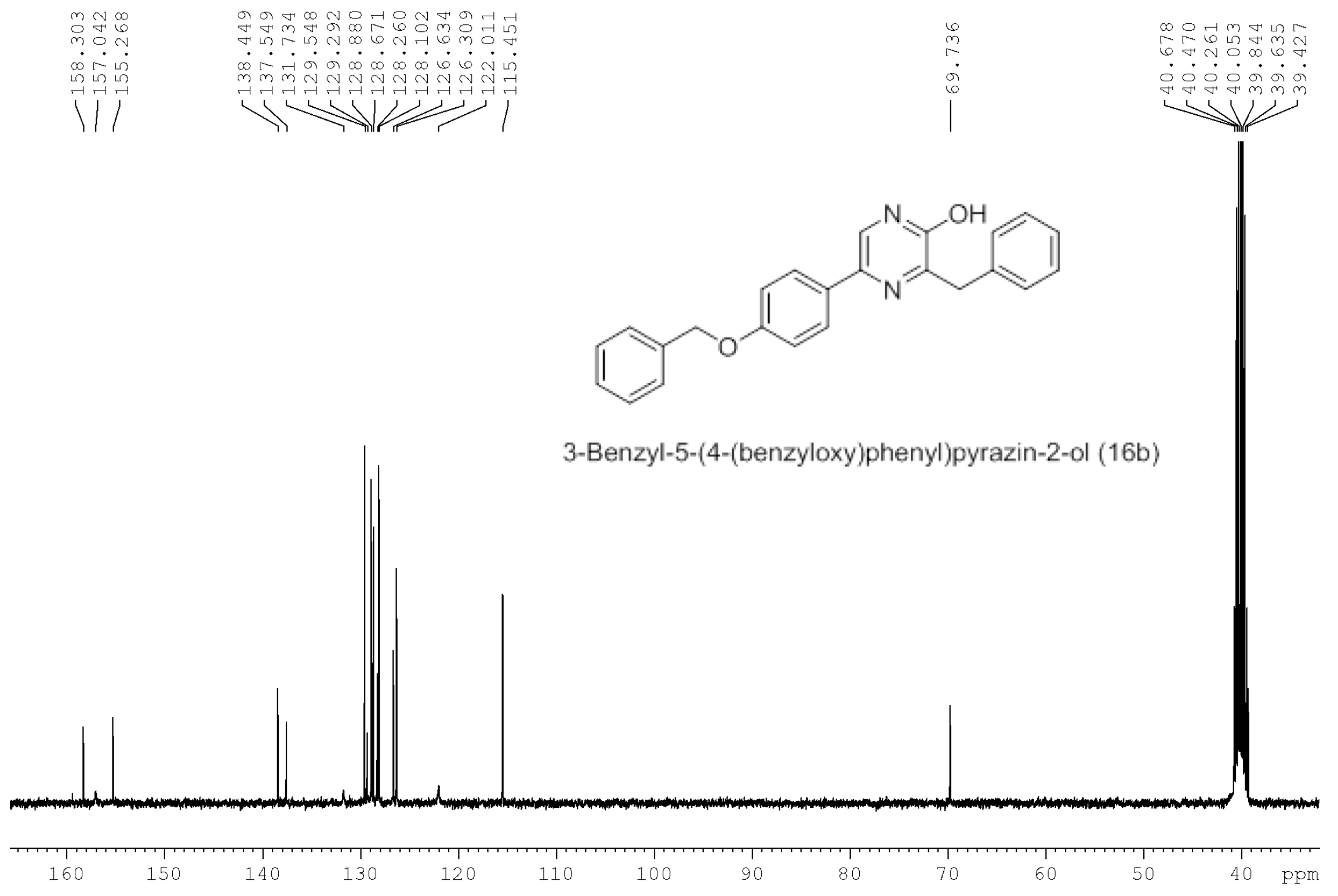




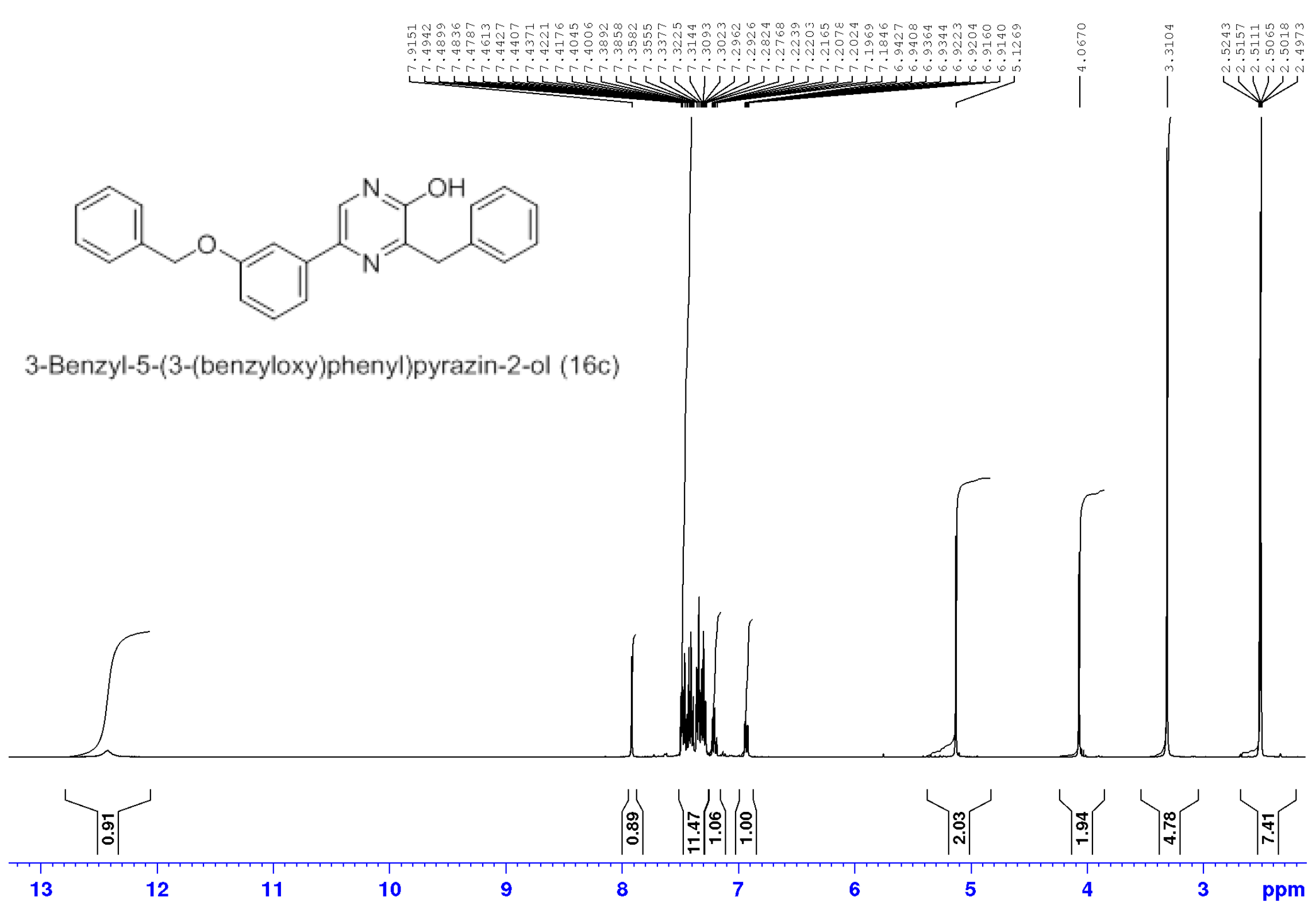




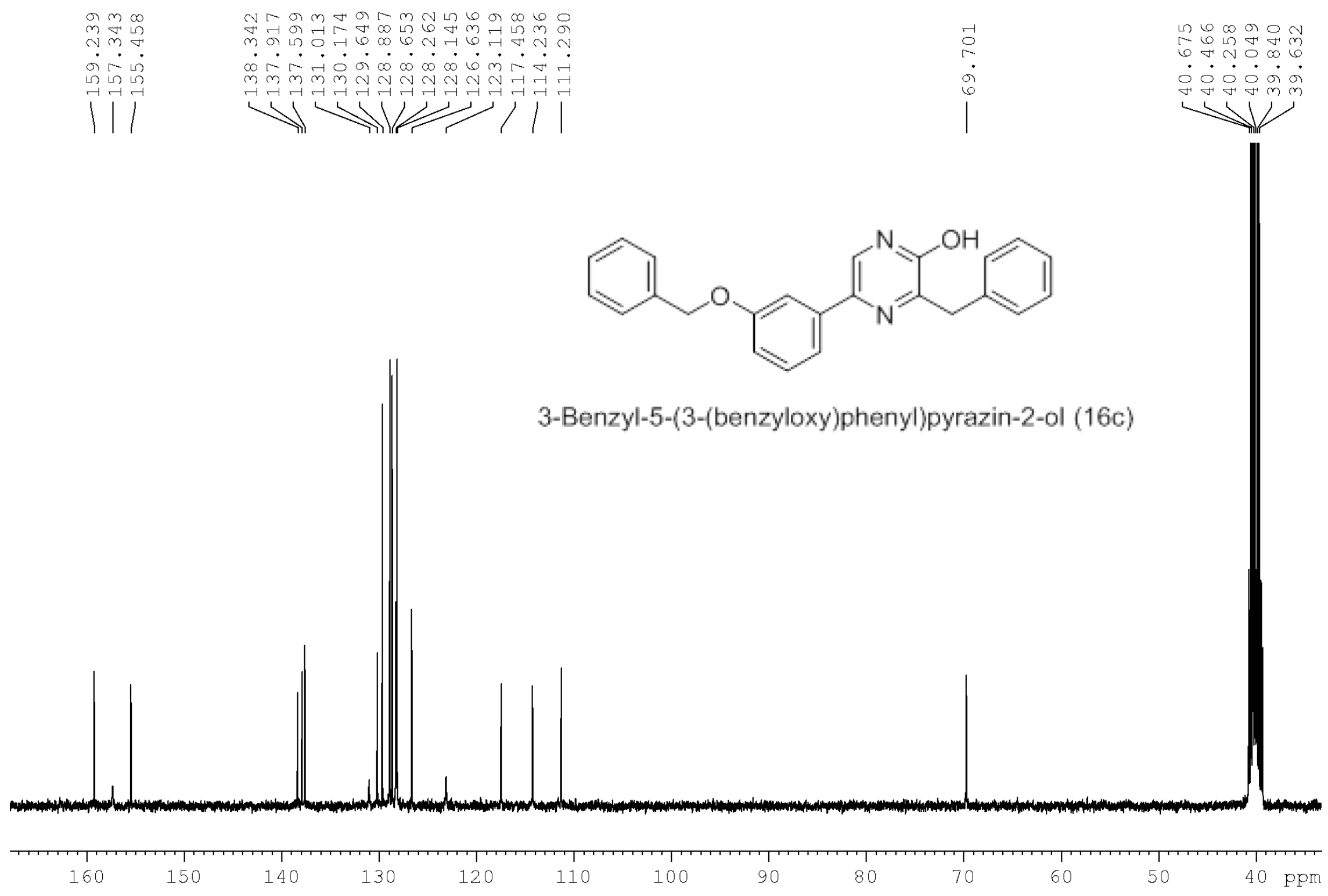




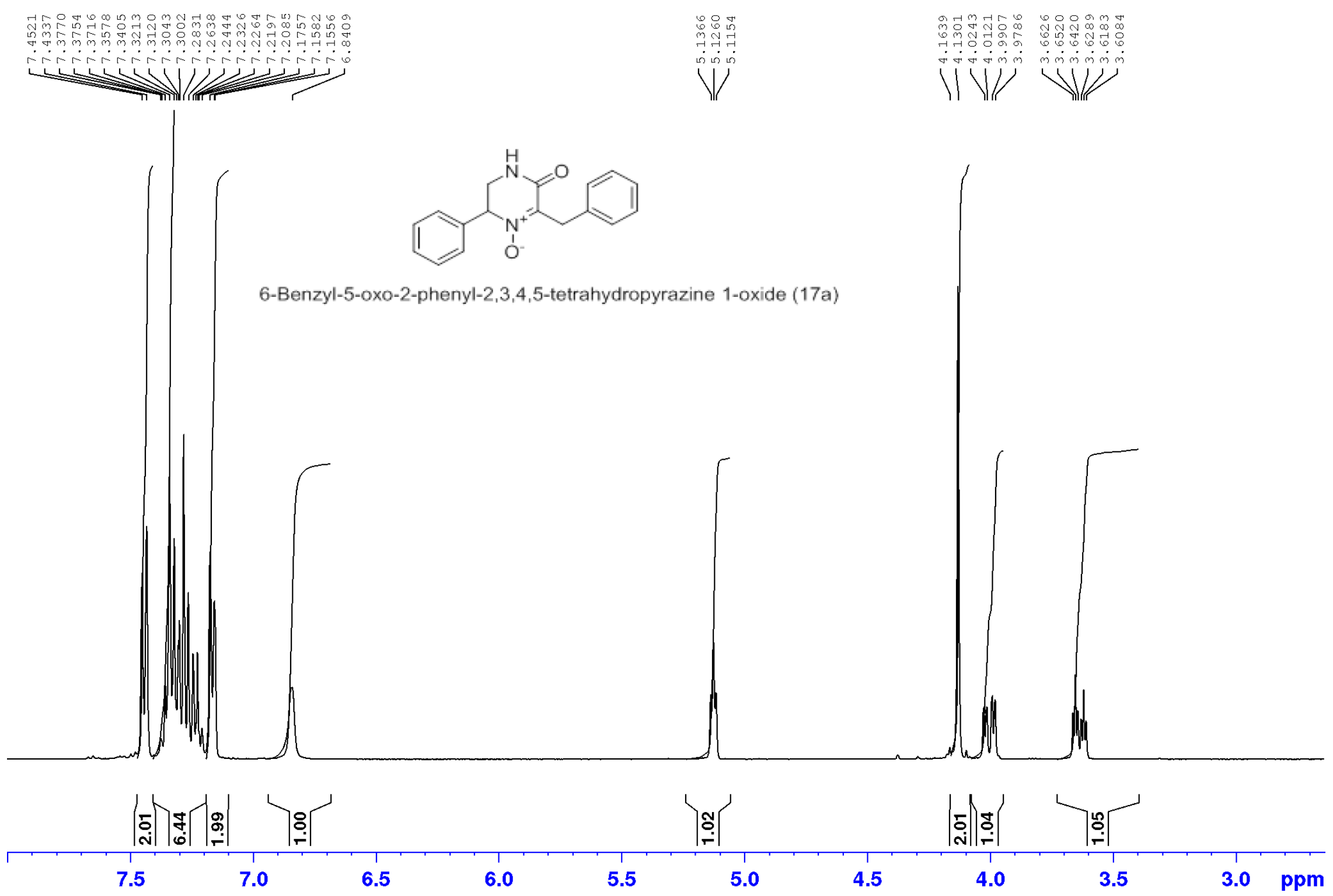


6-Benzyl-5-oxo-2-phenyl-2,3,4,5-tetrahydropyrazine 1-oxide (17a)

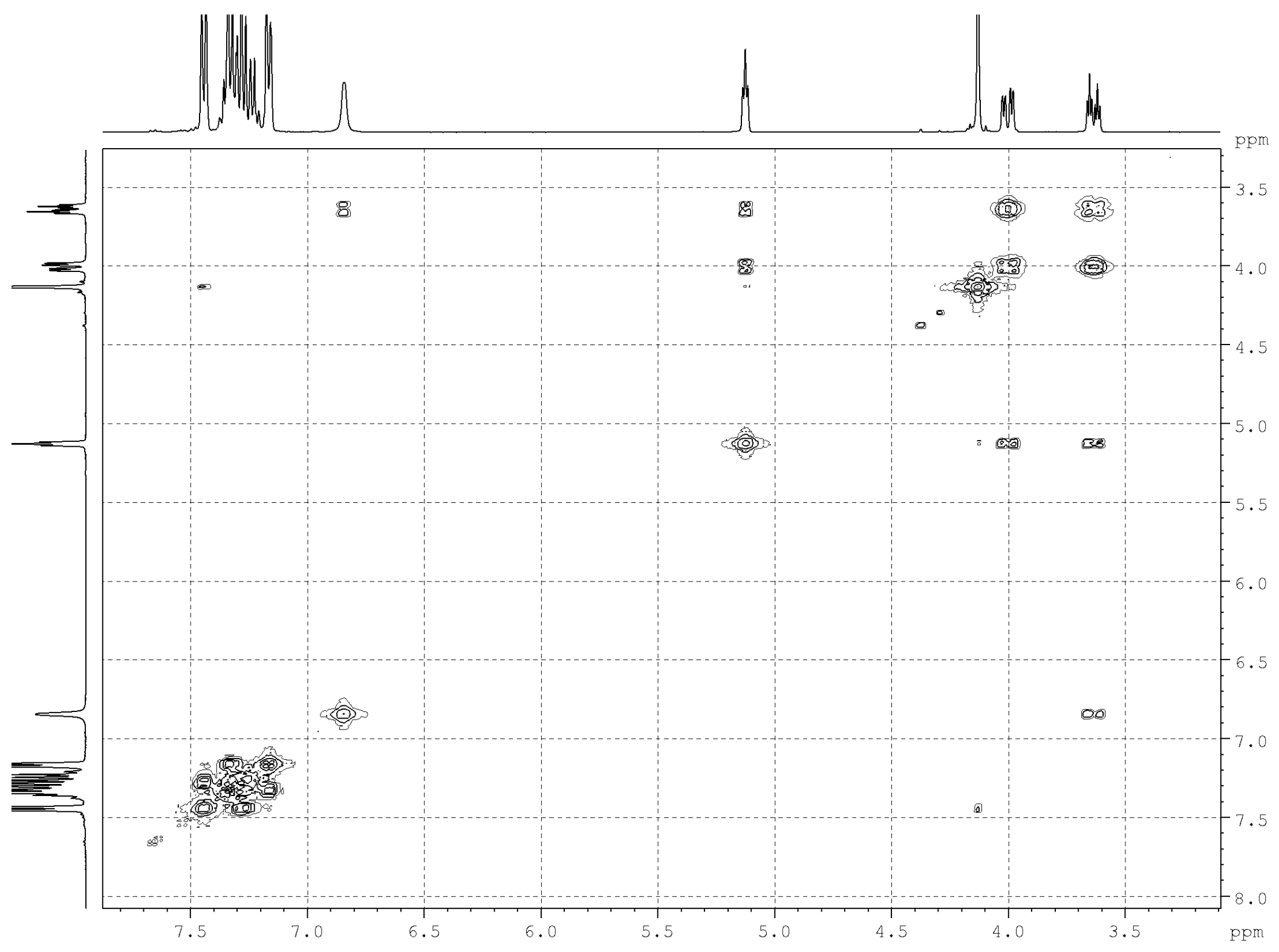




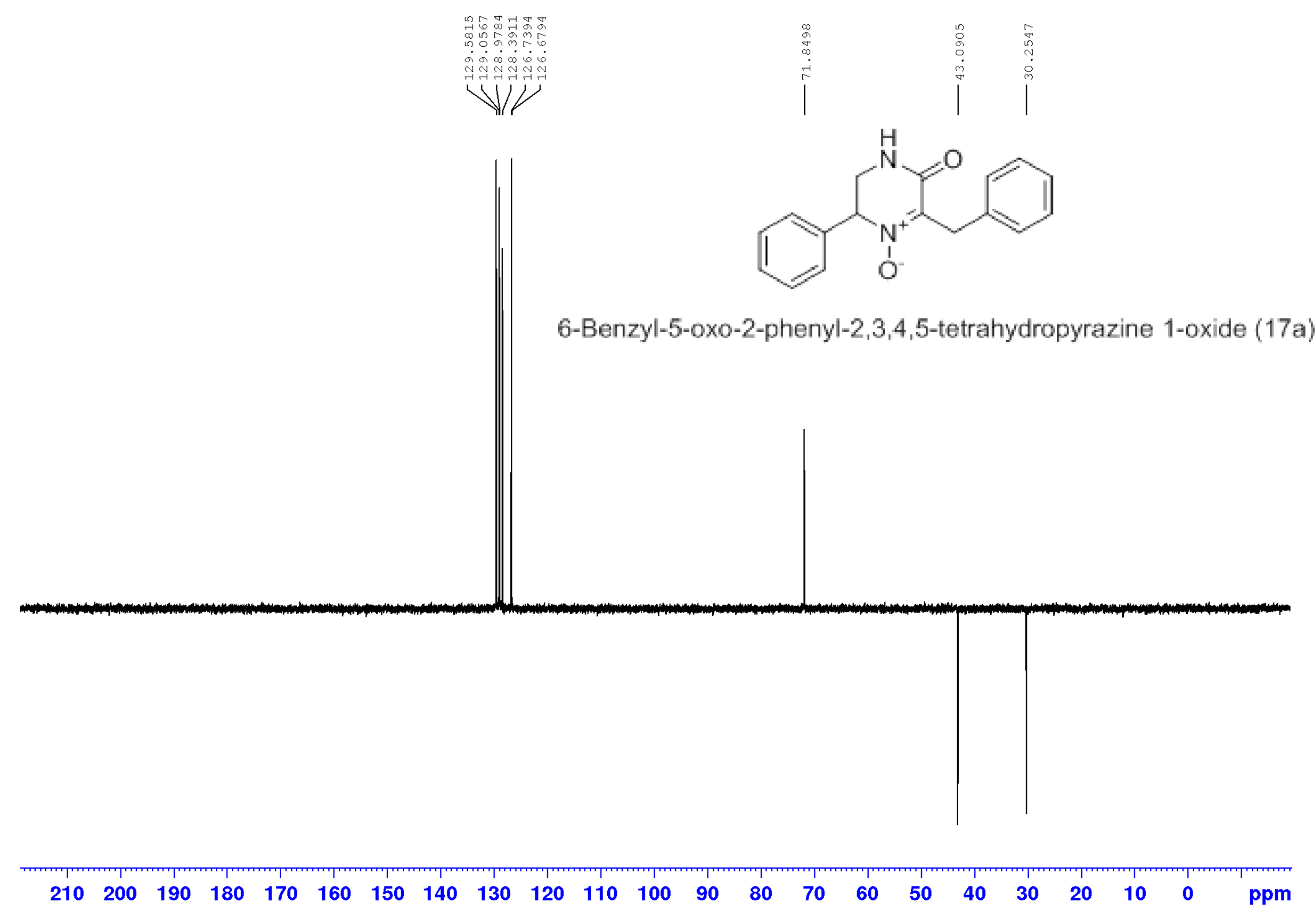





6-Benzyl-5-oxo-2-phenyl-2,3,4,5-tetrahydropyrazine 1-oxide (17a)

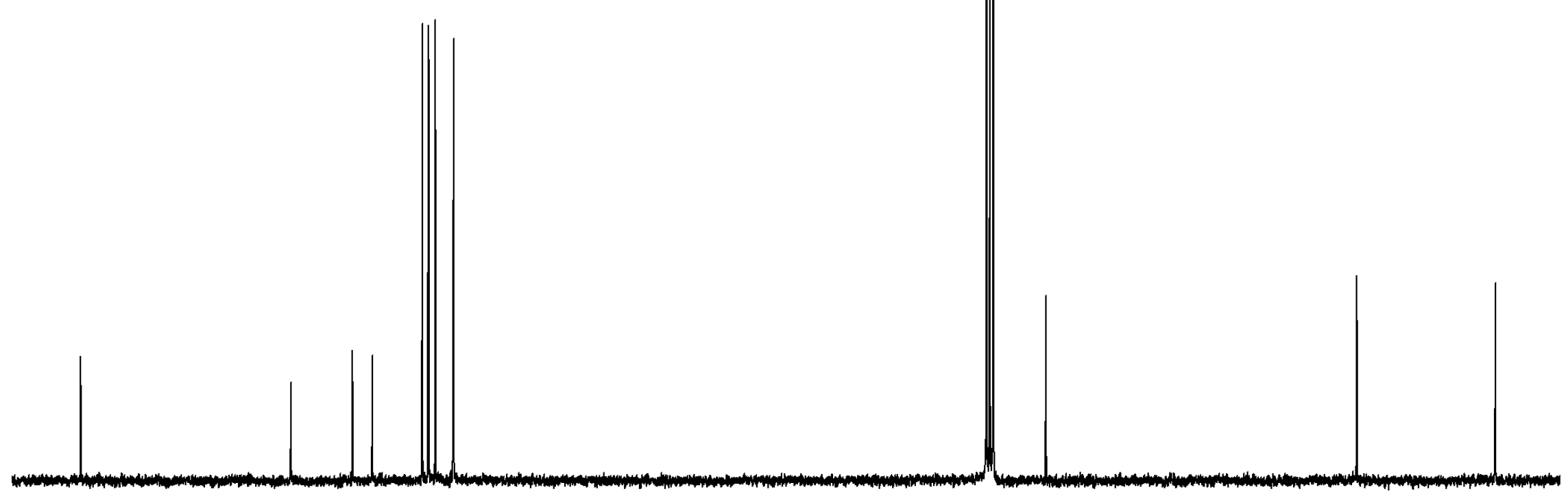




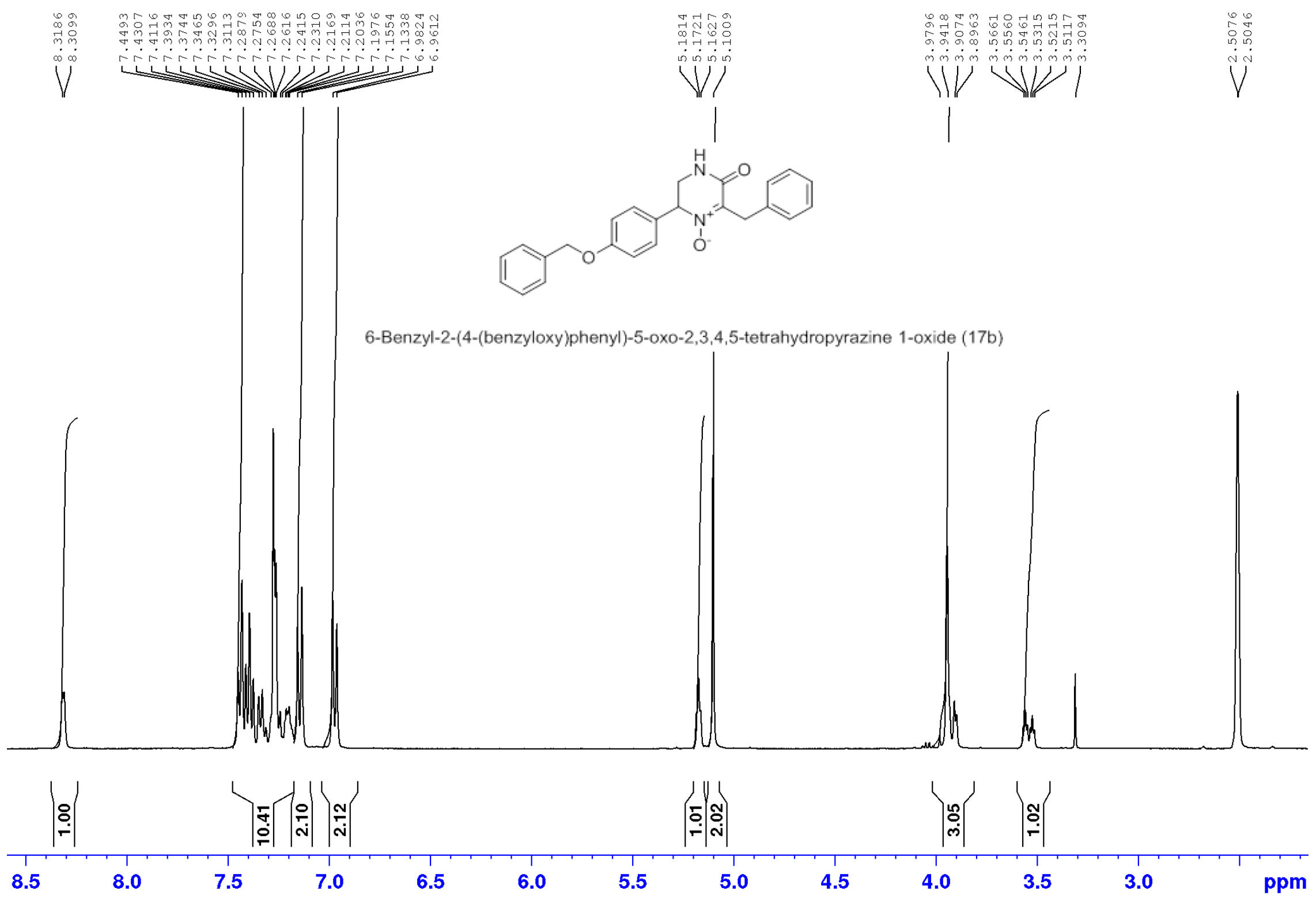


6-Benzyl-2-(4-(benzyloxy)phenyl)-5-oxo-2,3,4,5-tetrahydropyrazine 1-oxide (17b)

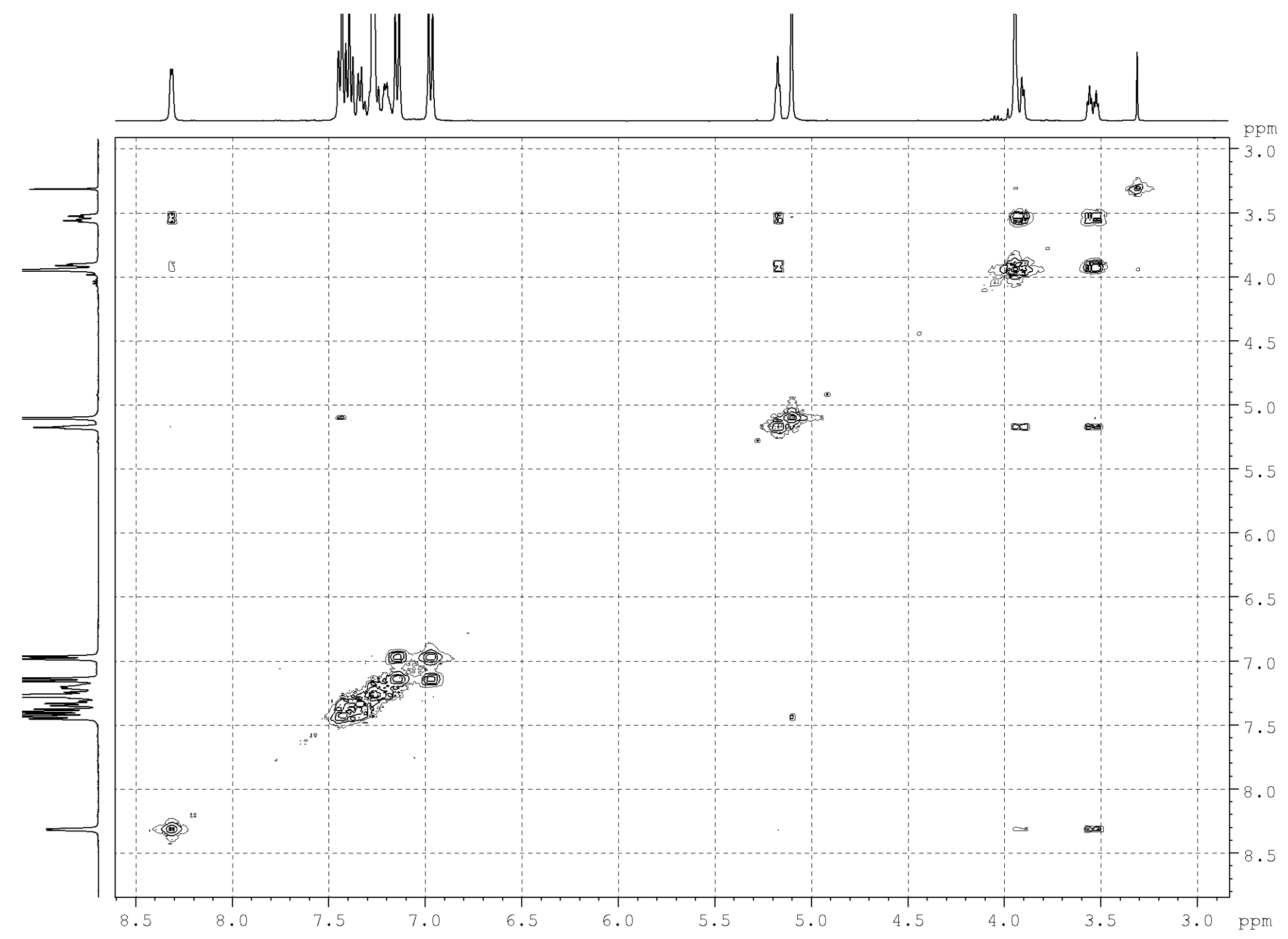




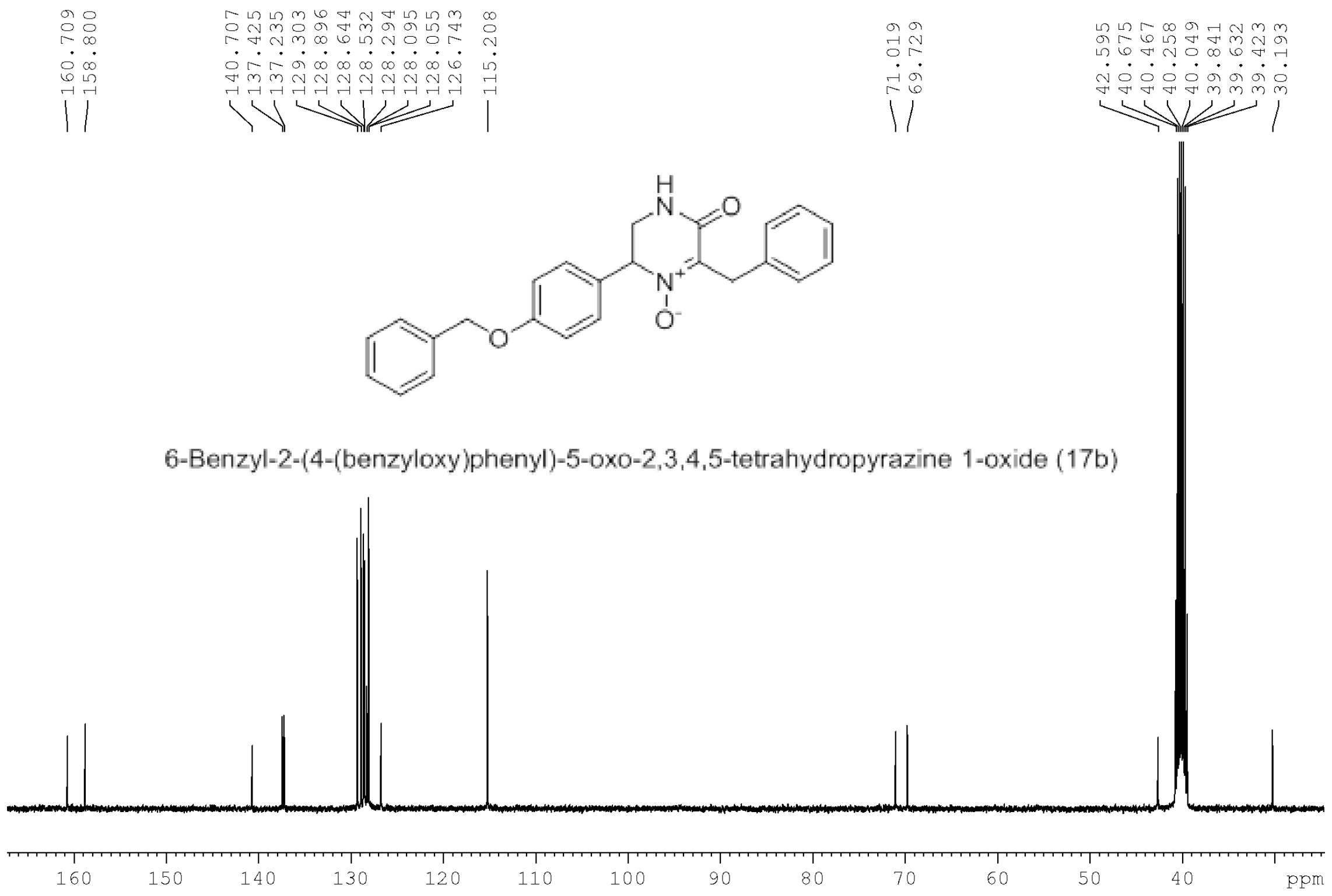




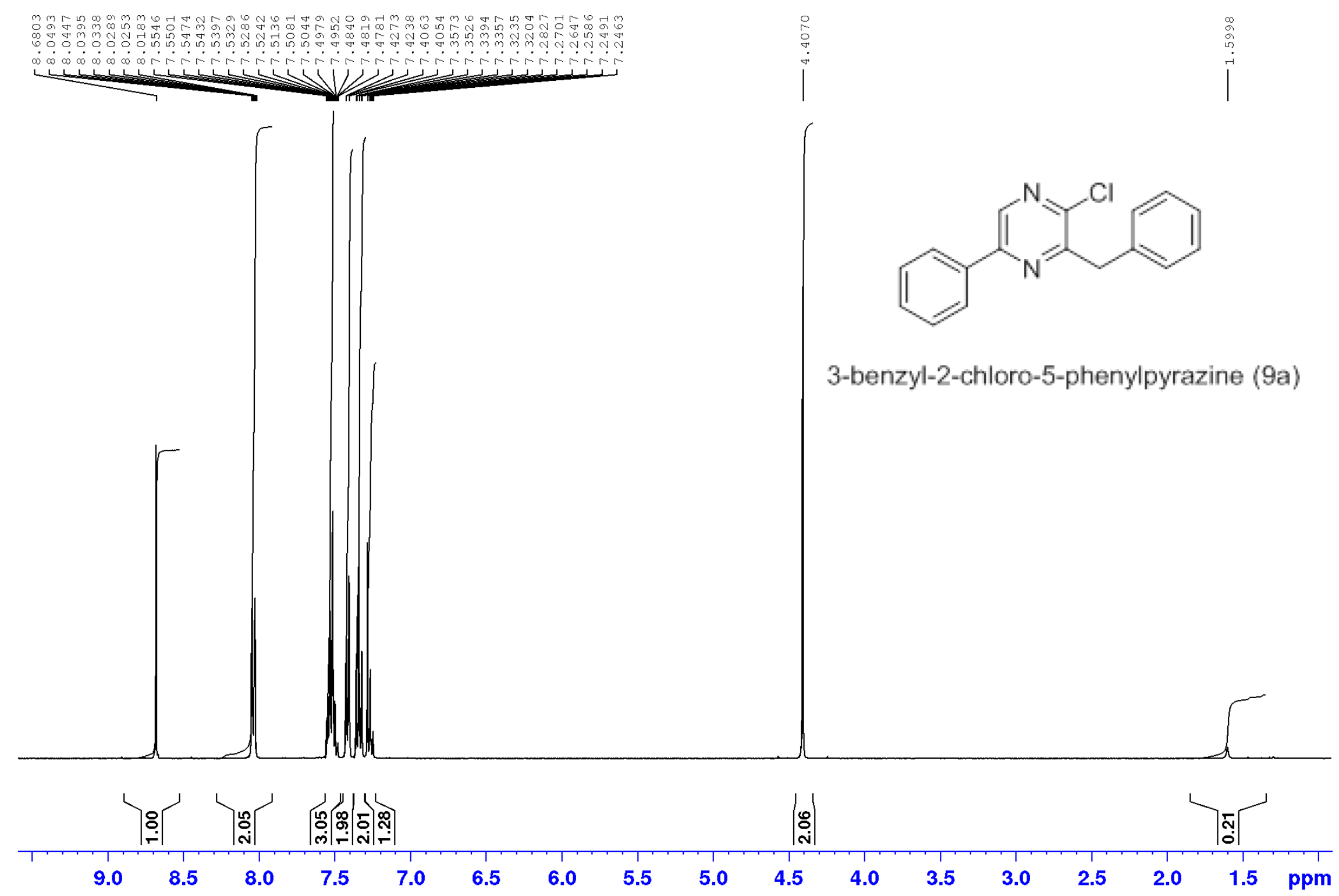



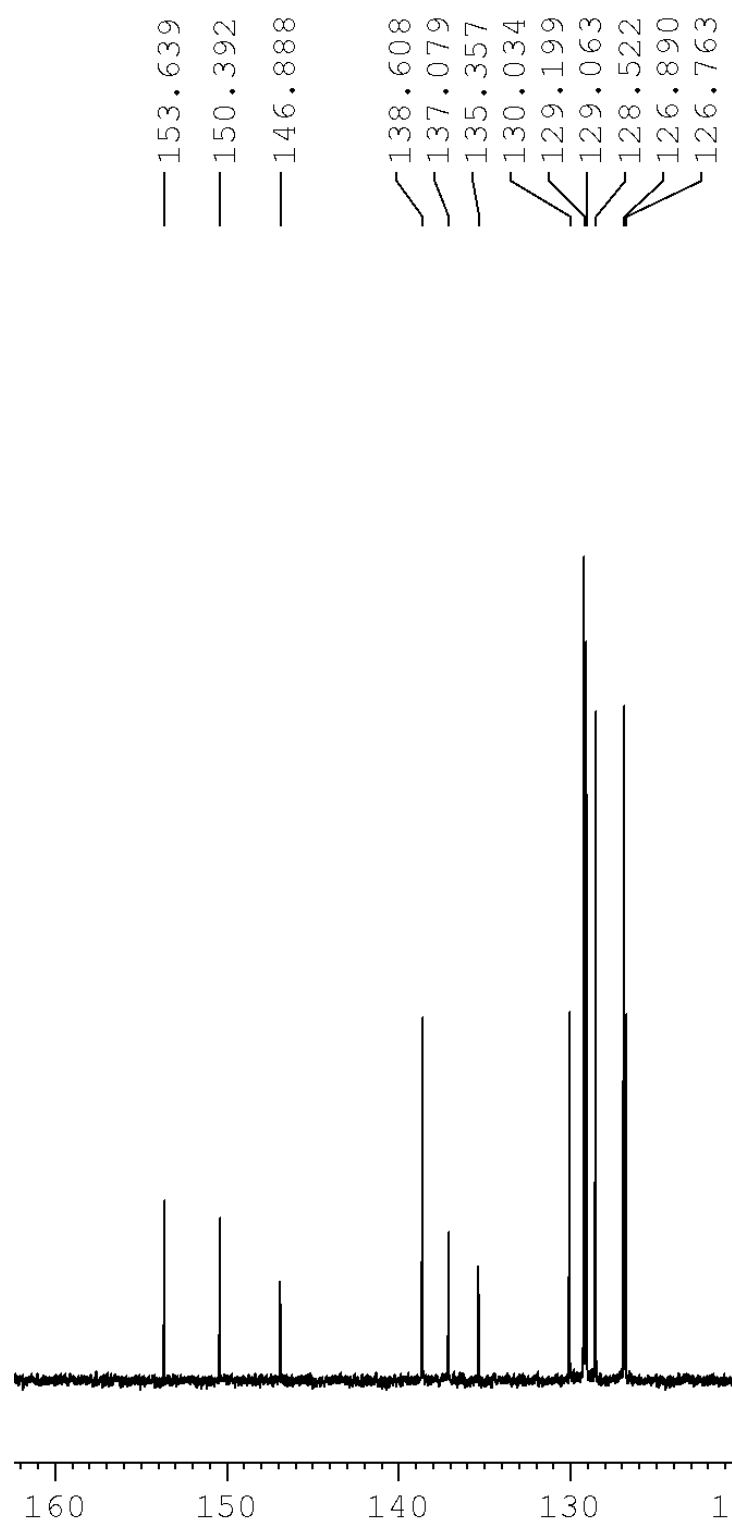



m.

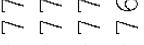

VI

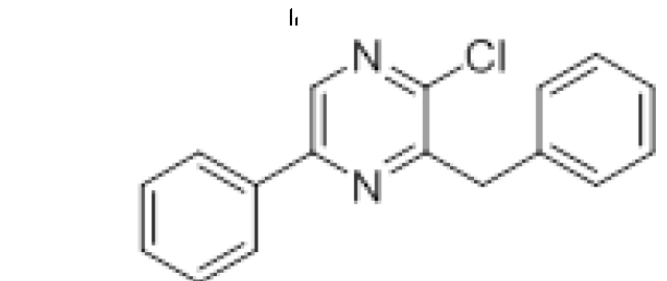

3-benzyl-2-chloro-5-phenylpyrazine (9a)

\section{3-benzyl-2-chloro-5-phenylpyrazine (9a)}

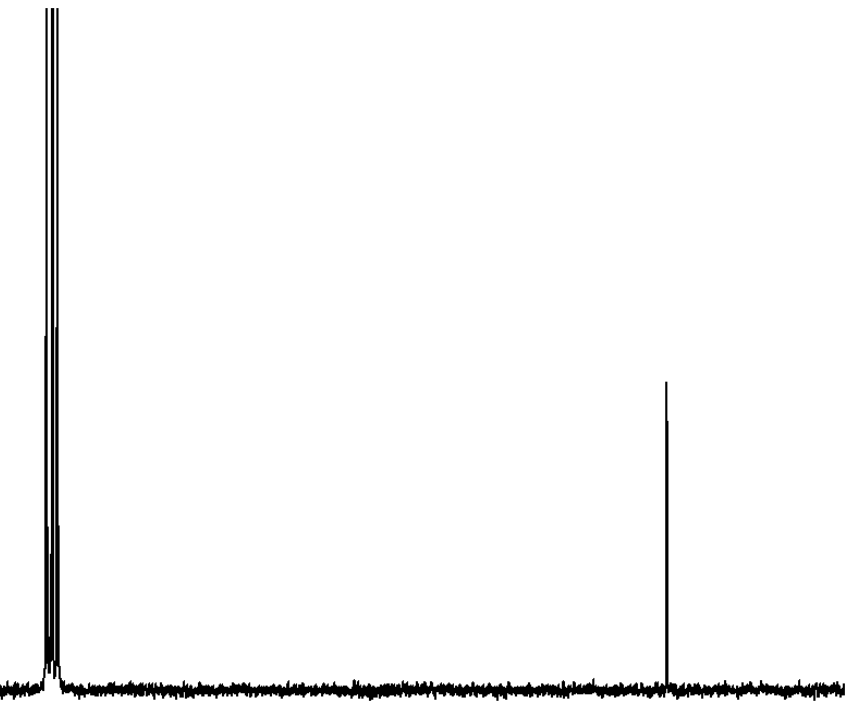




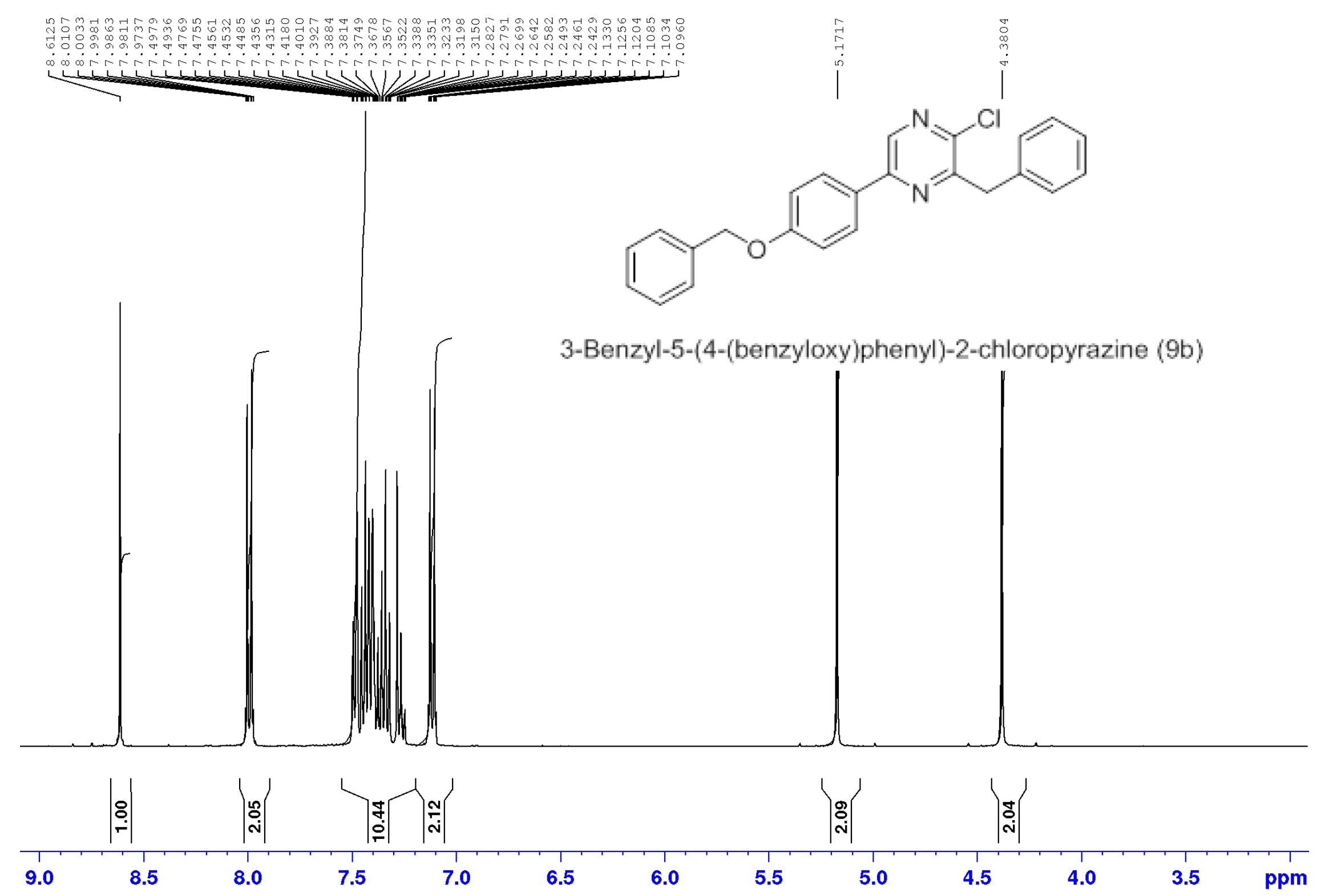




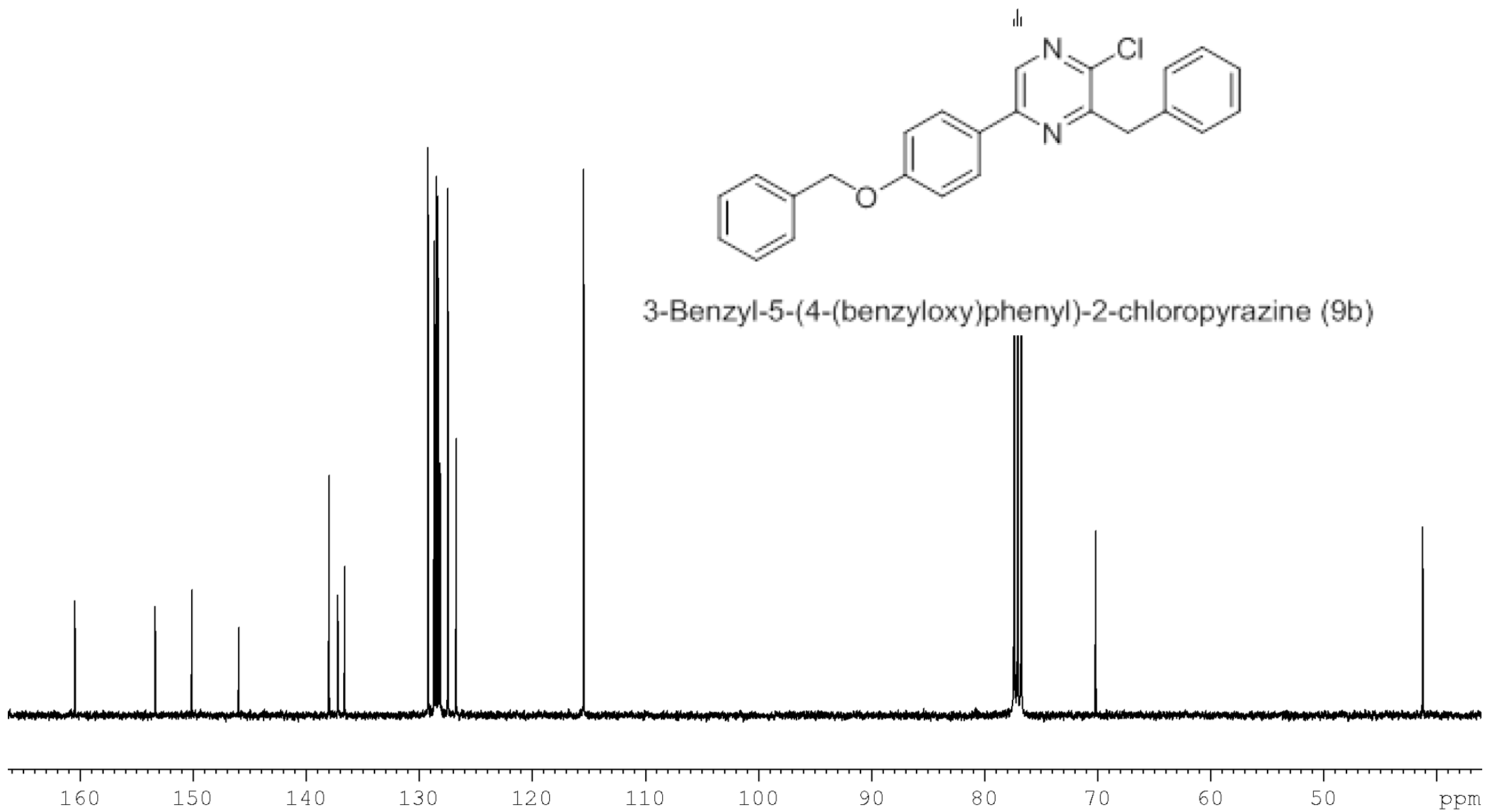




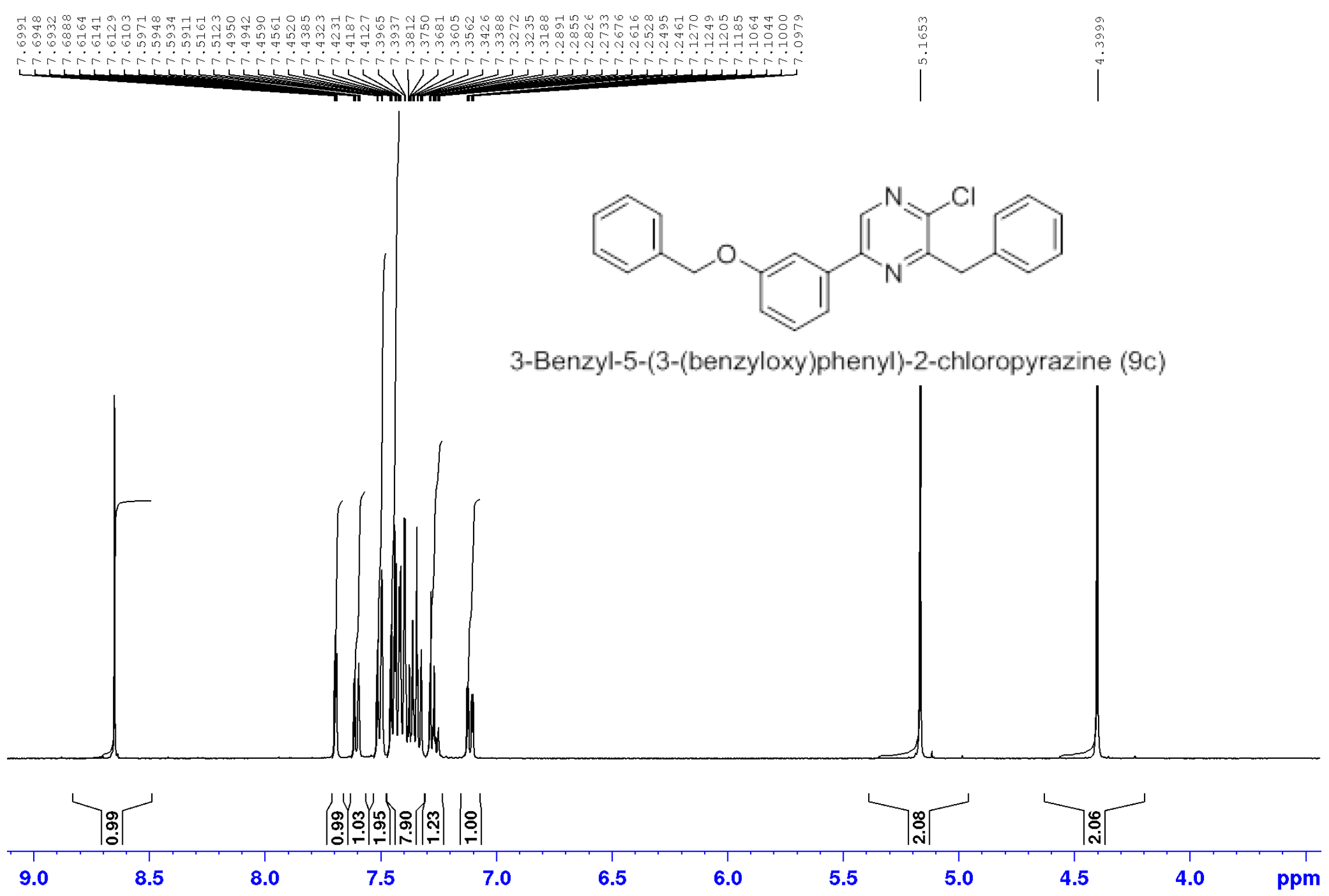


<smiles>Clc1ncc(-c2cccc(OCc3ccccc3)c2)nc1Cc1ccccc1</smiles>

3-Benzyl-5-(3-(benzyloxy)phenyl)-2-chloropyrazine (9c)

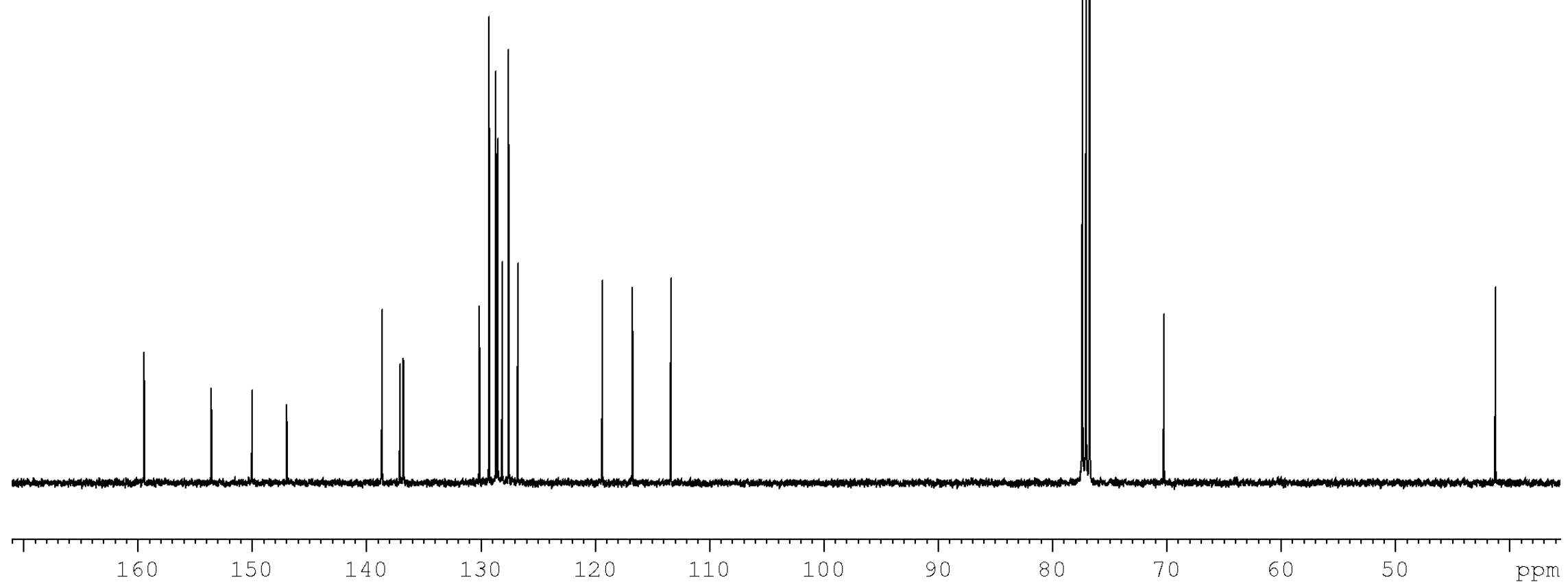




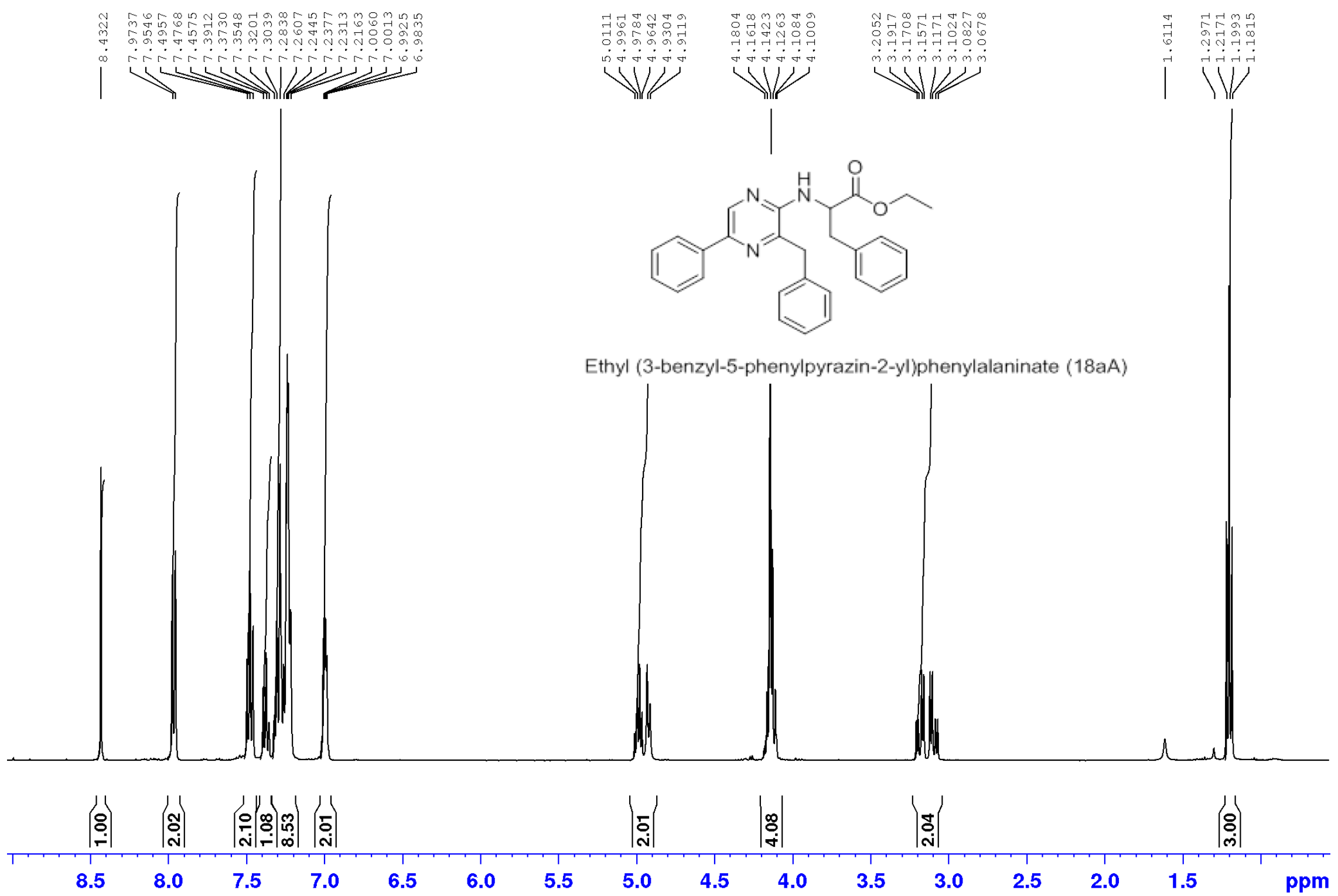



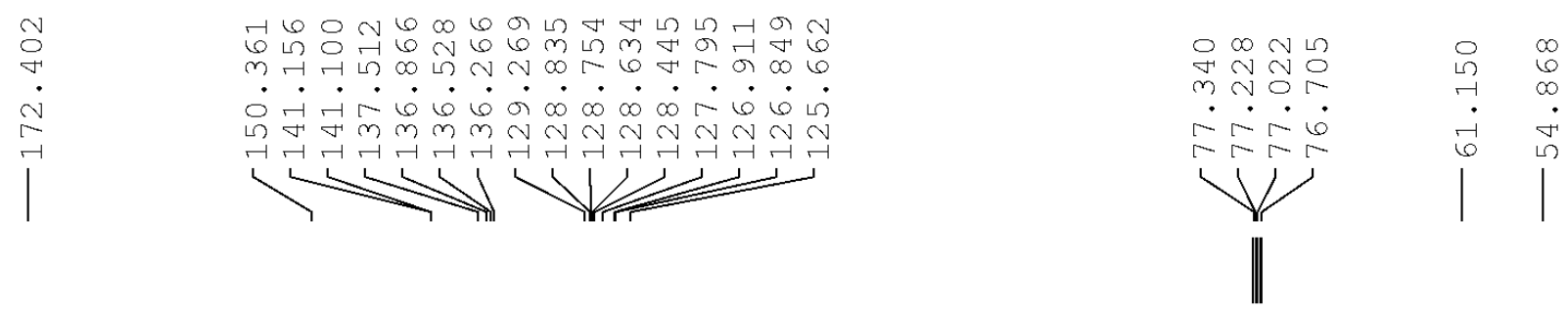



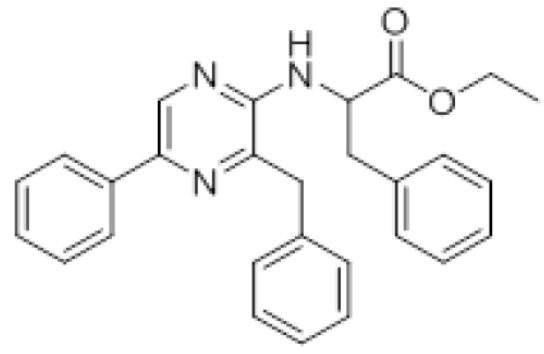

Ethyl (3-benzyl-5-phenylpyrazin-2-yl)phenylalaninate (18aA)

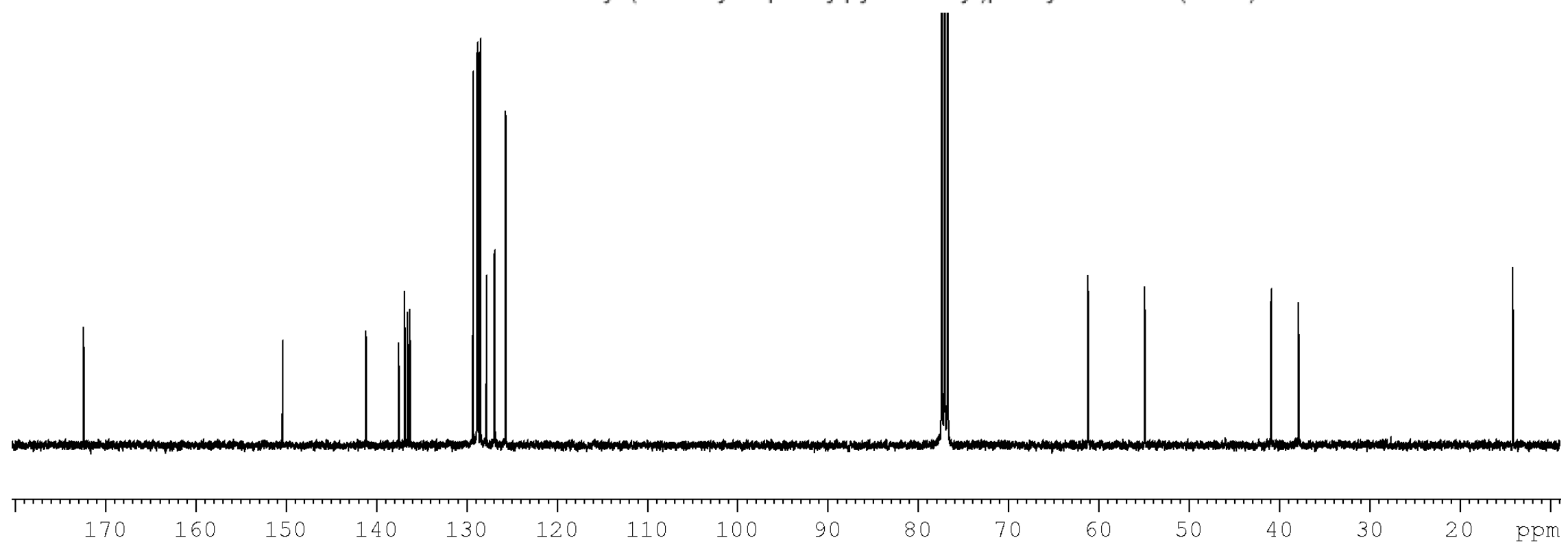




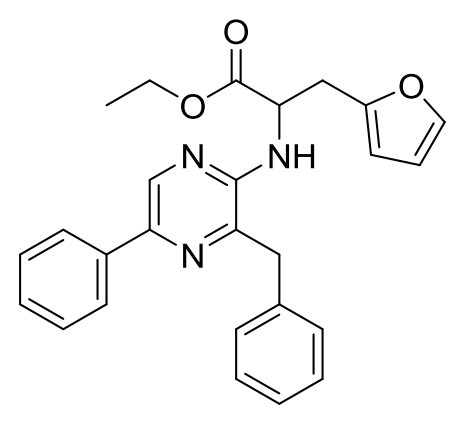

Ethyl 2-((3-benzyl-5-phenylpyrazin-2-yl)amino)-3-(furan-2-yl)propanoate (18aB) 


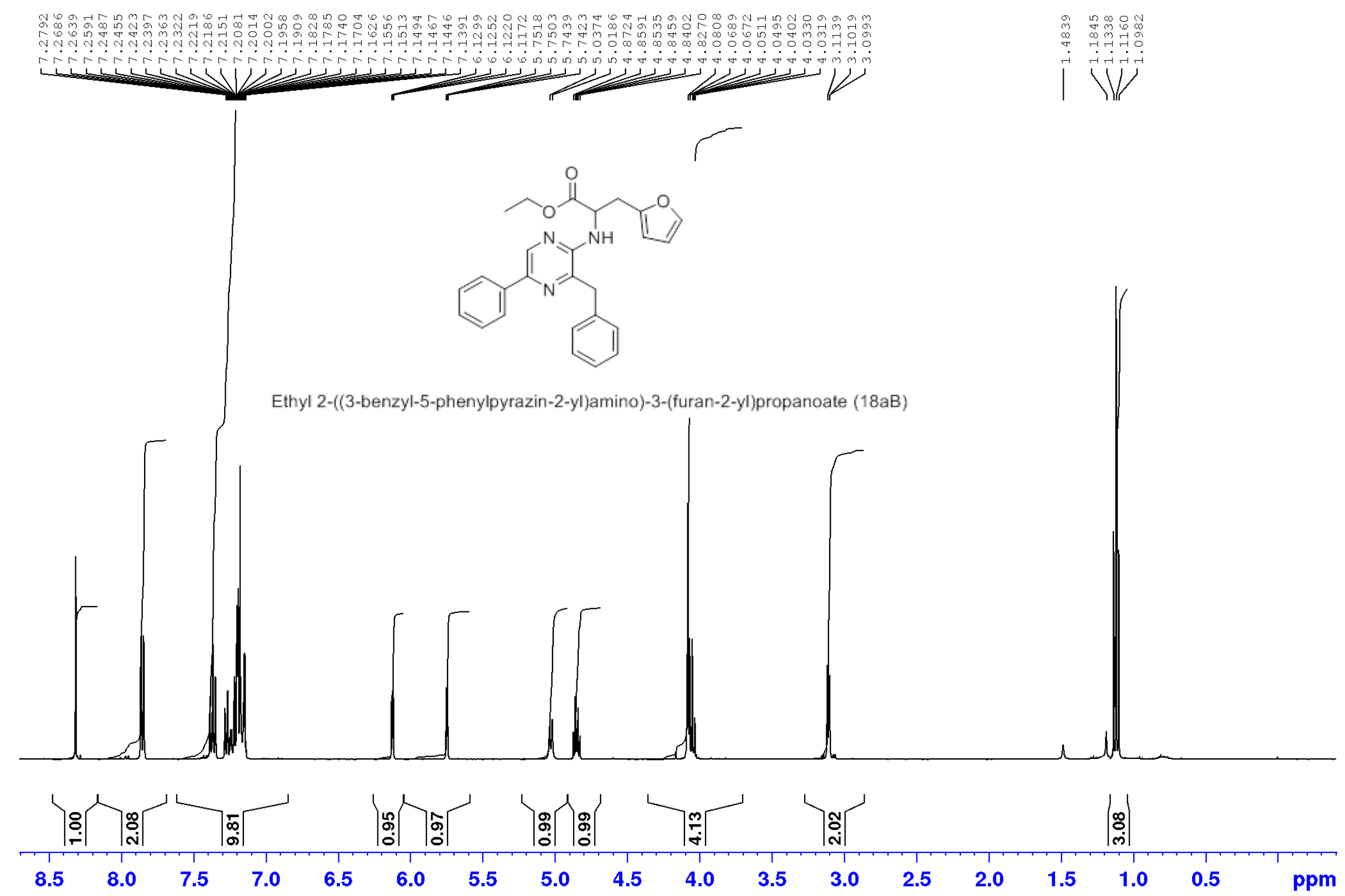









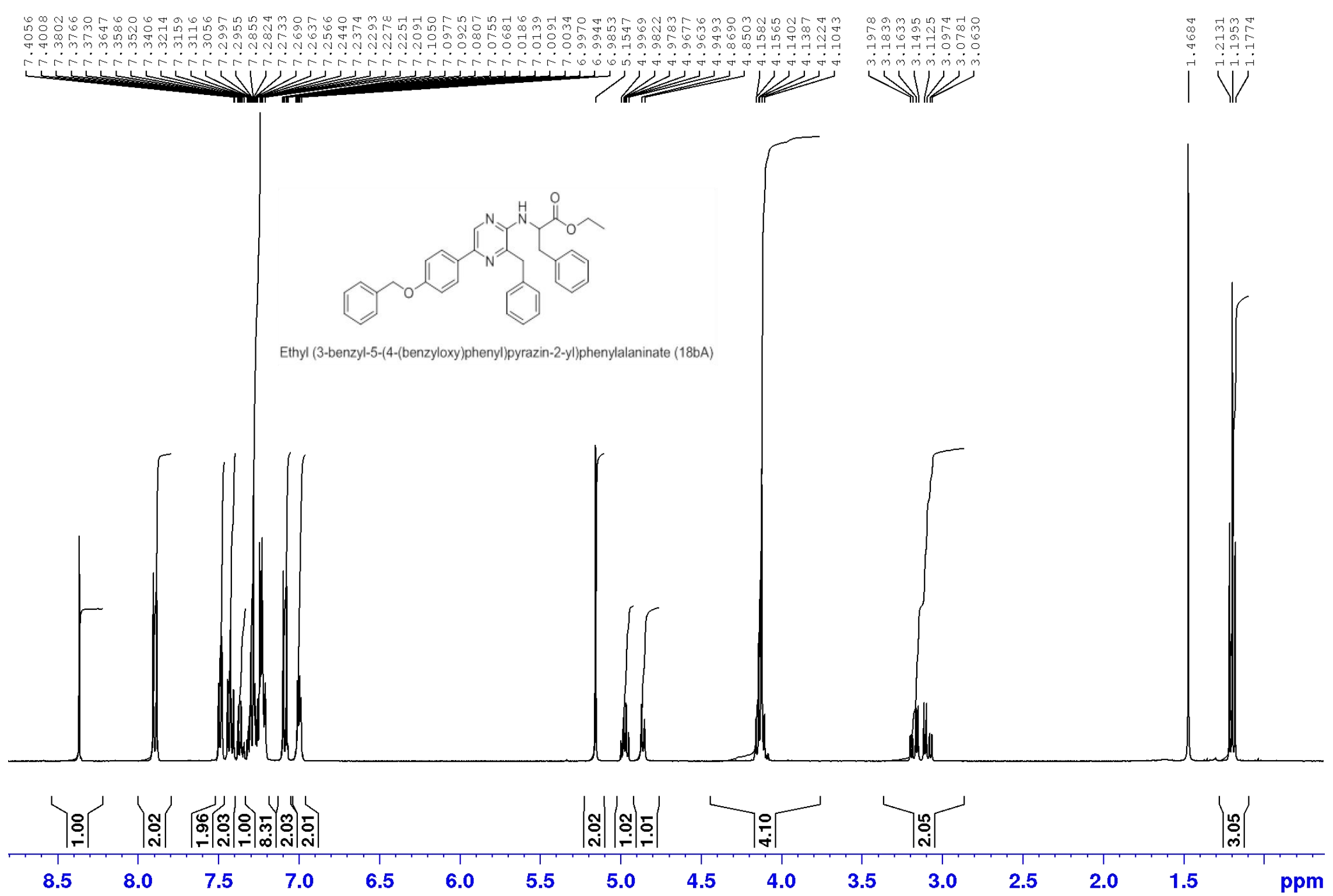




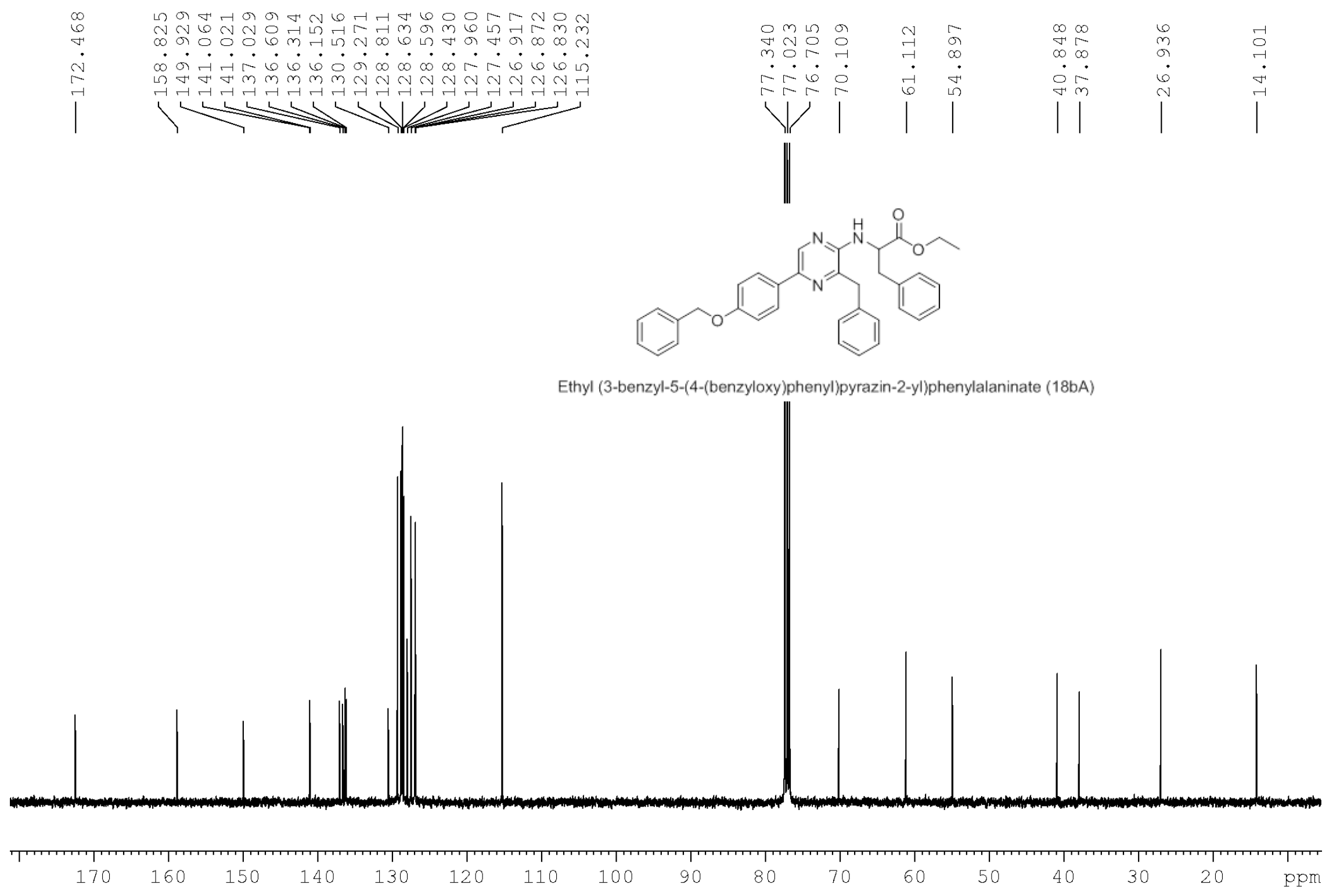





Ethyl 2-((3-benzyl-5-(4-(benzyloxy)phenyl)pyrazin-2-yl)amino)-3-(furan-2-yl)propanoate (18bB)

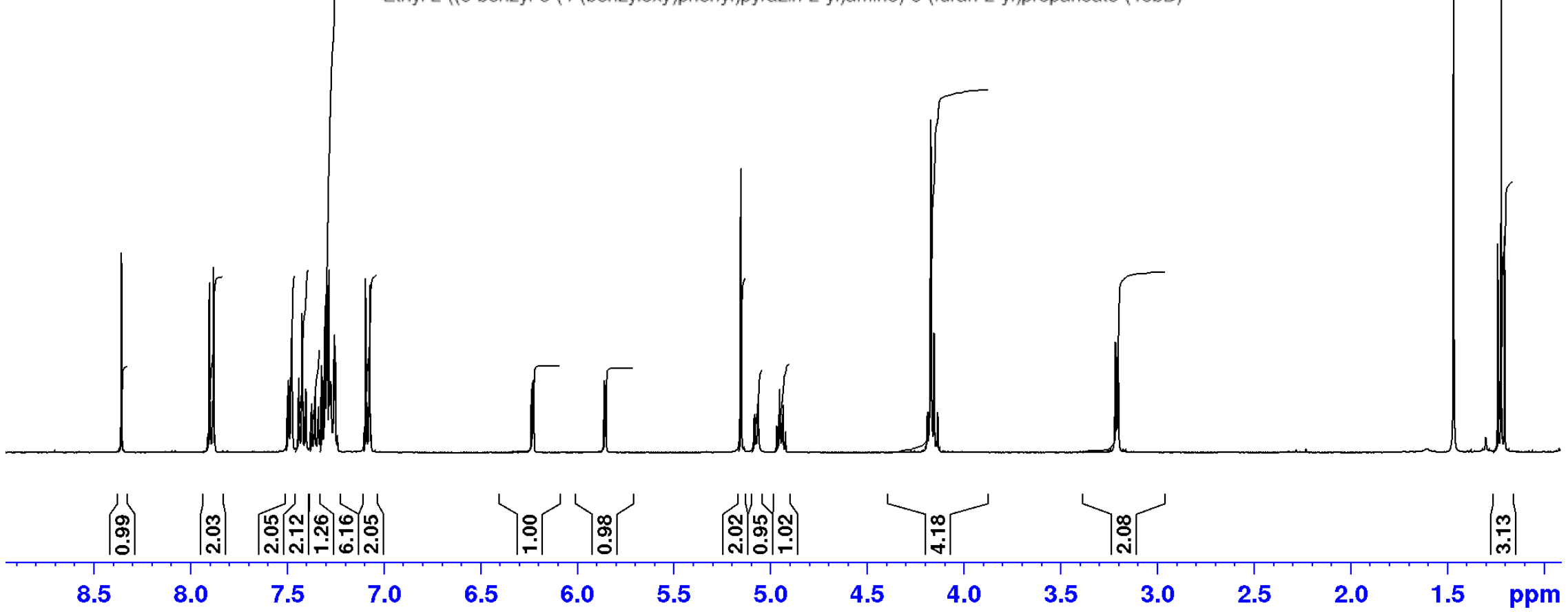





Ethyl 2-((3-benzyl-5-(4-(benzyloxy)phenyl)pyrazin-2-yl)amino)-3-(furan-2-yl)propanoate (18bB)

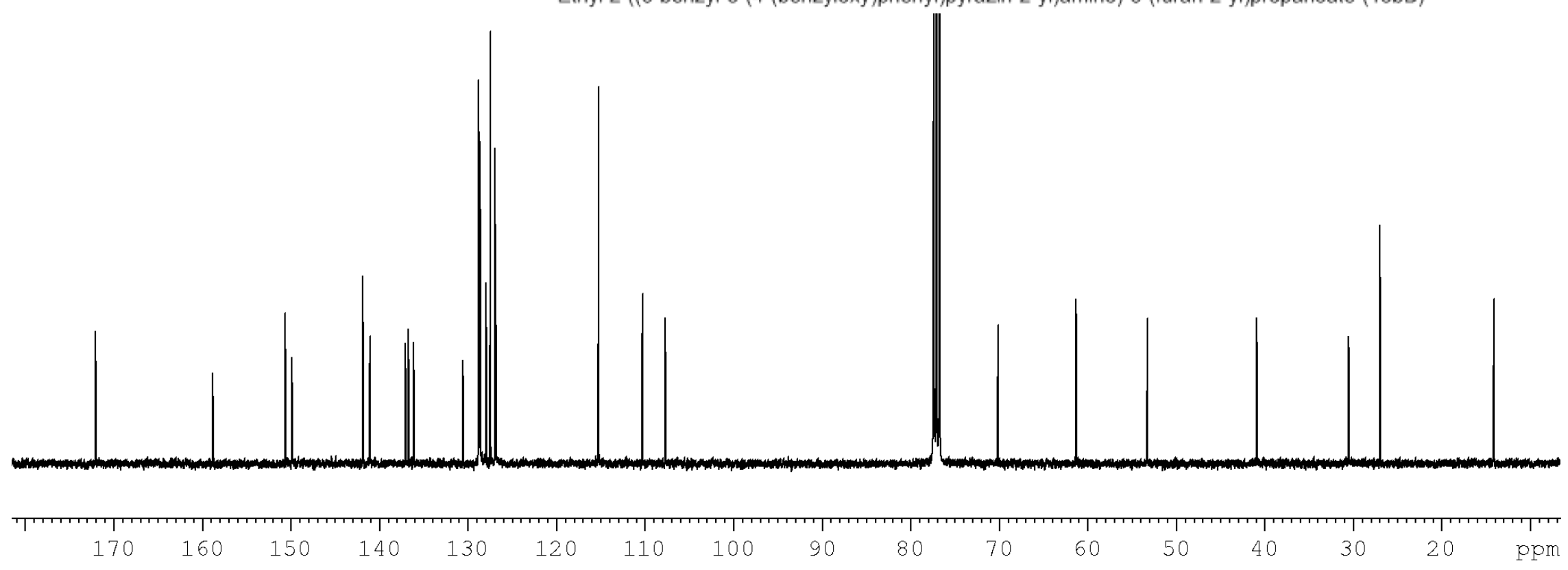




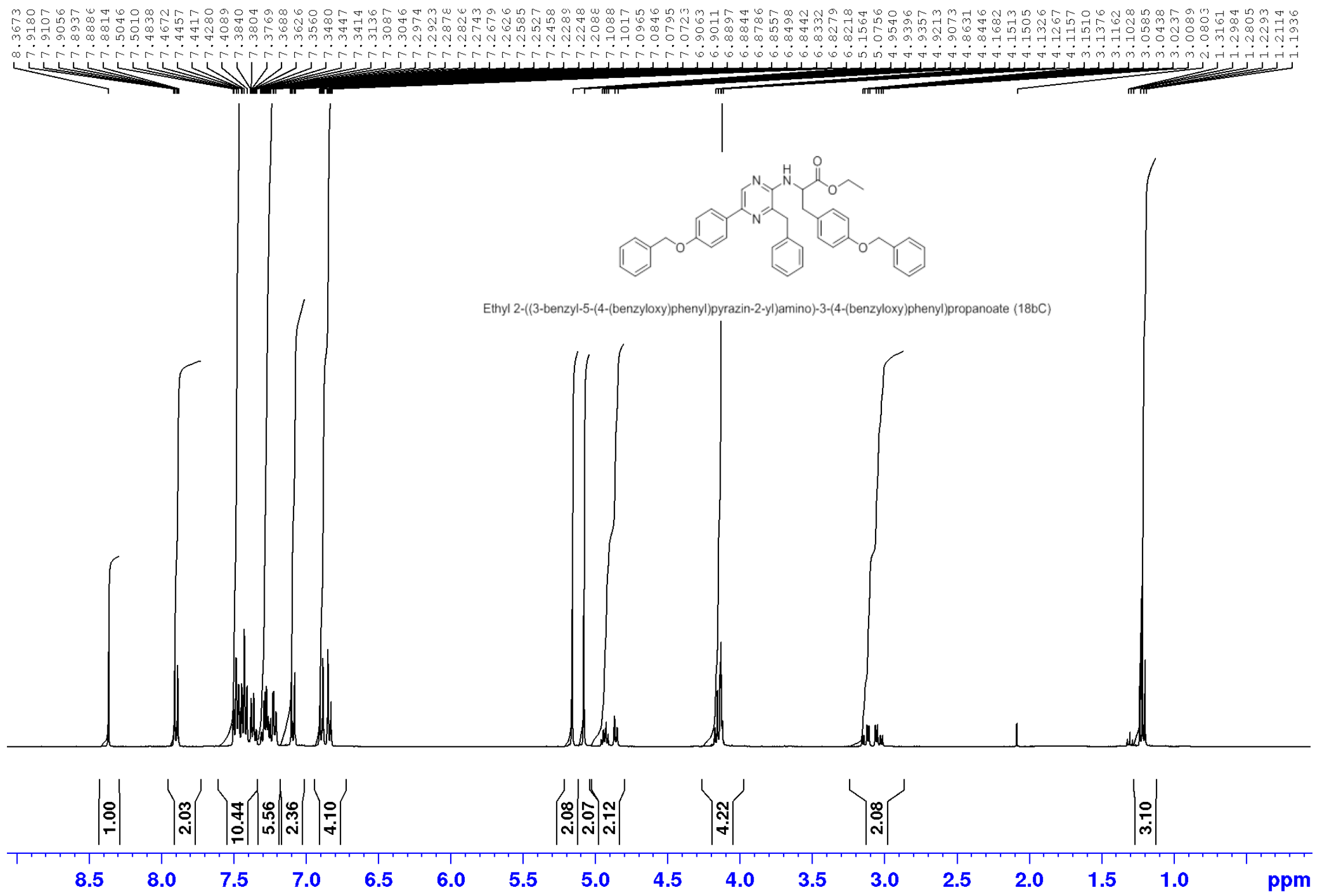




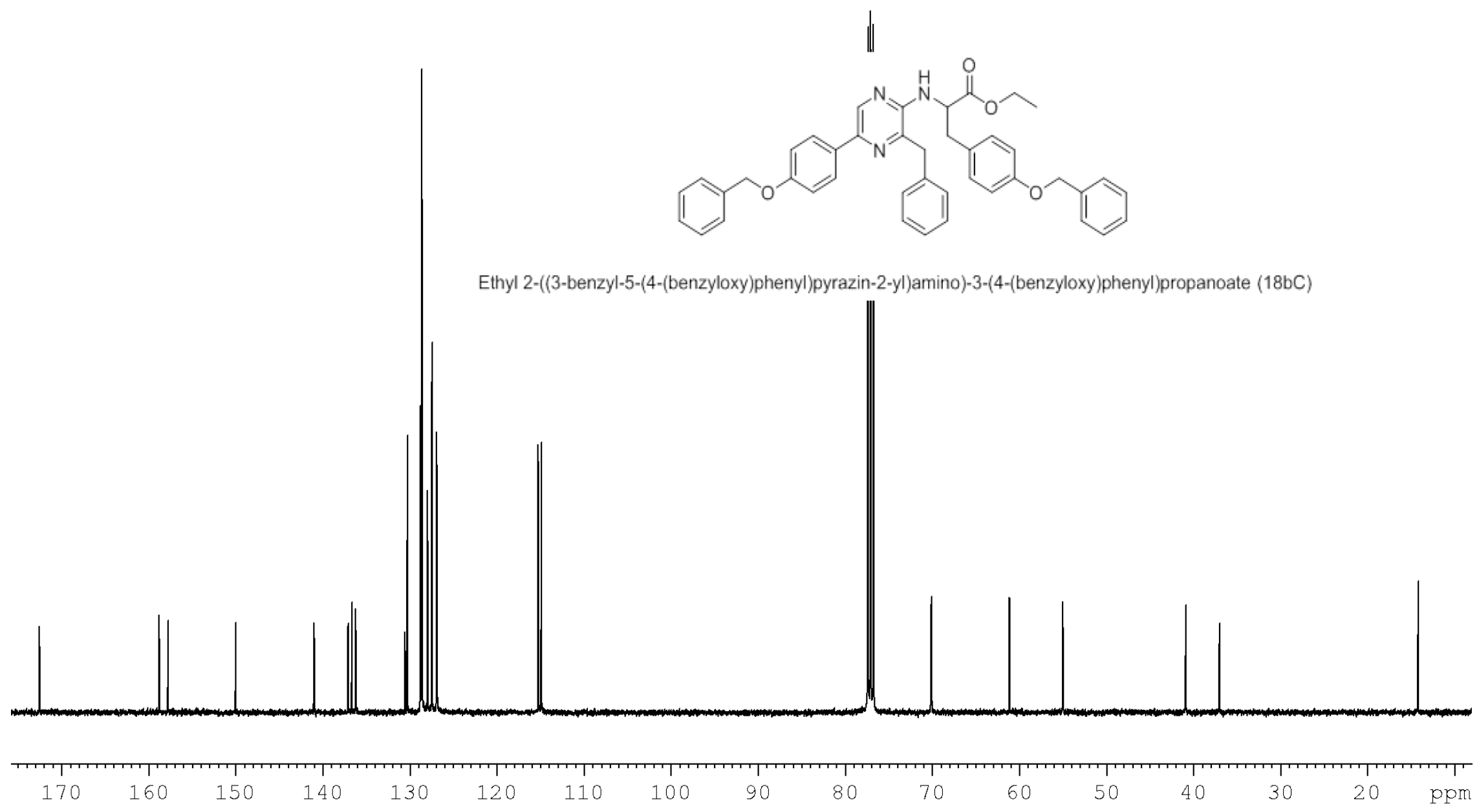




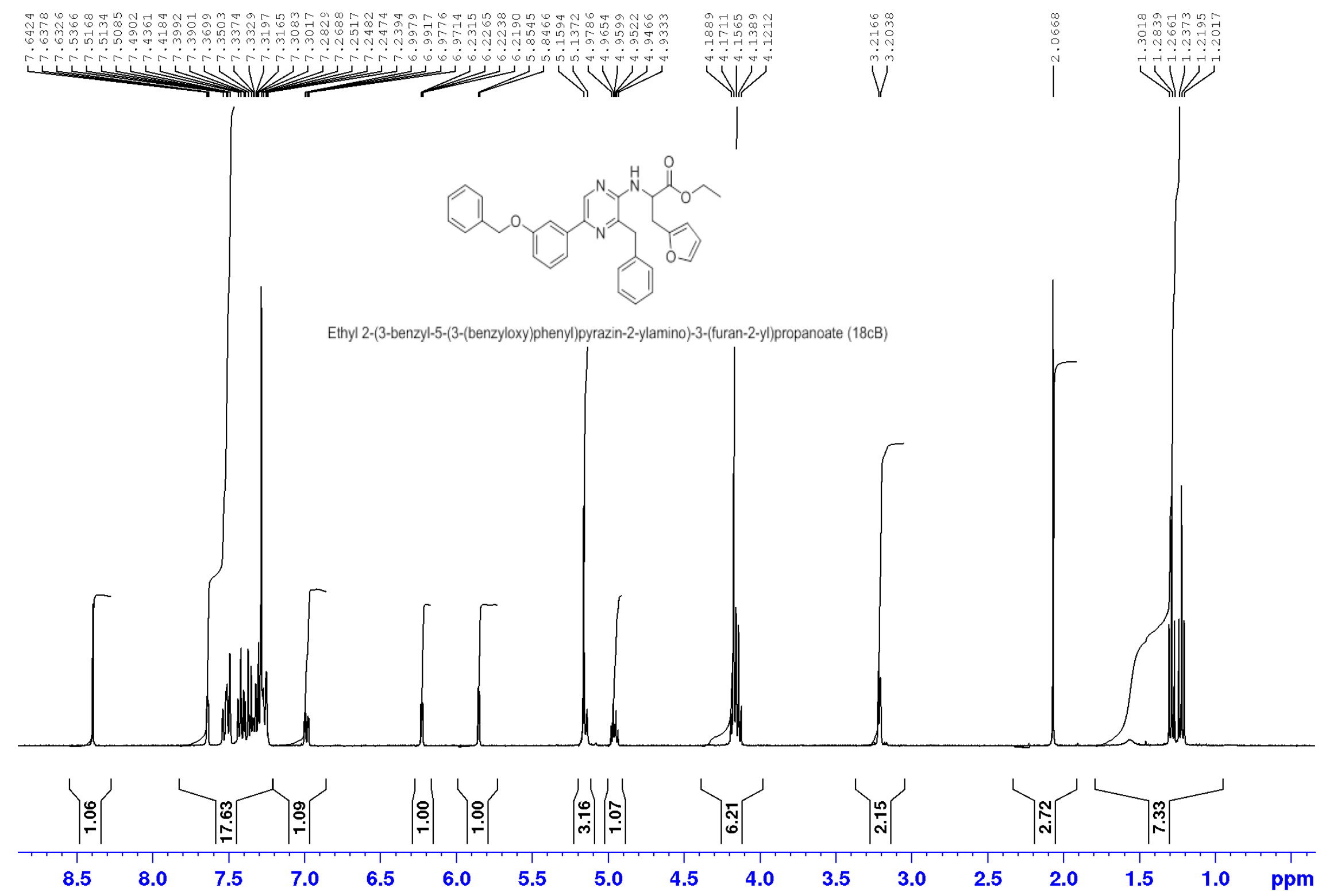




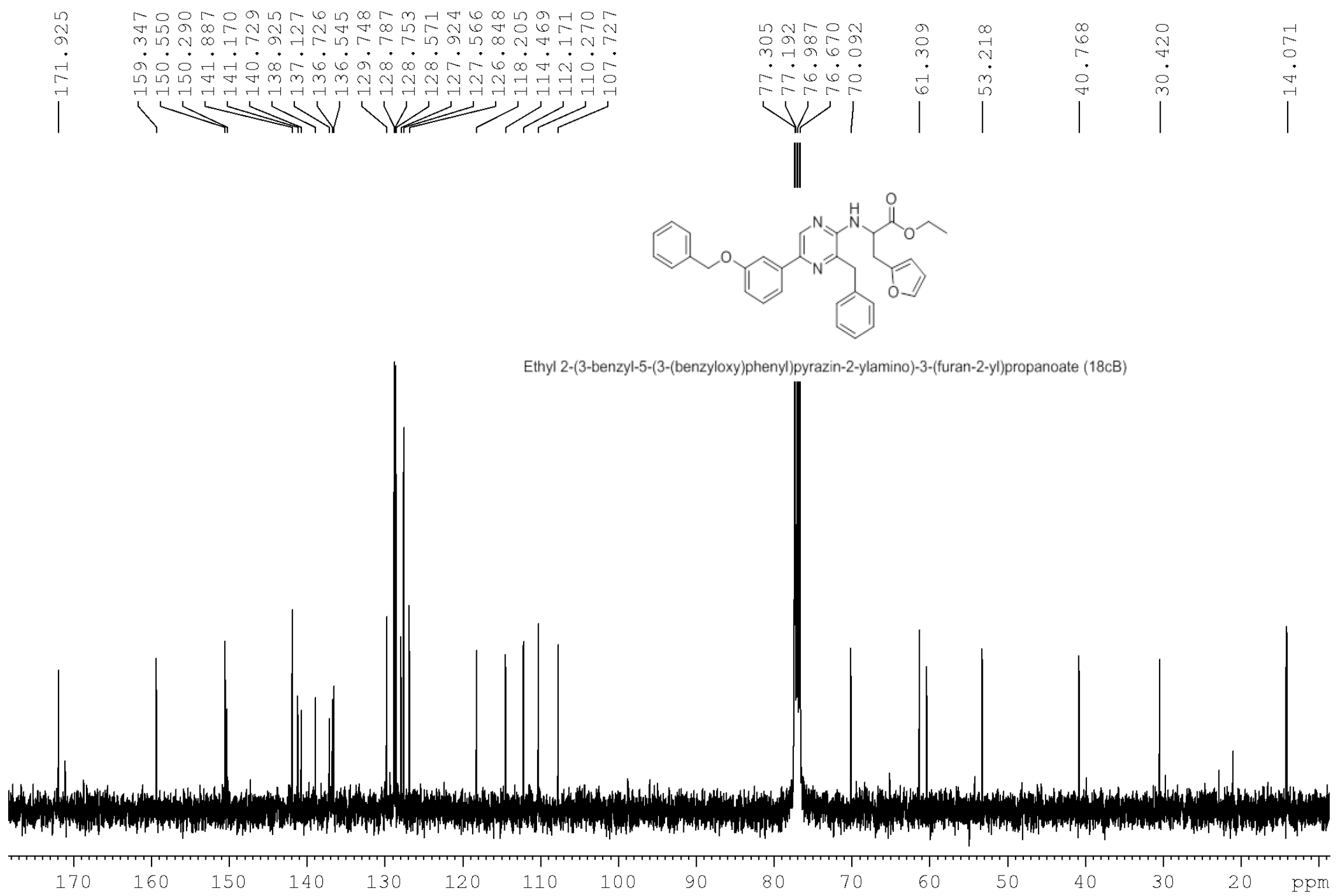




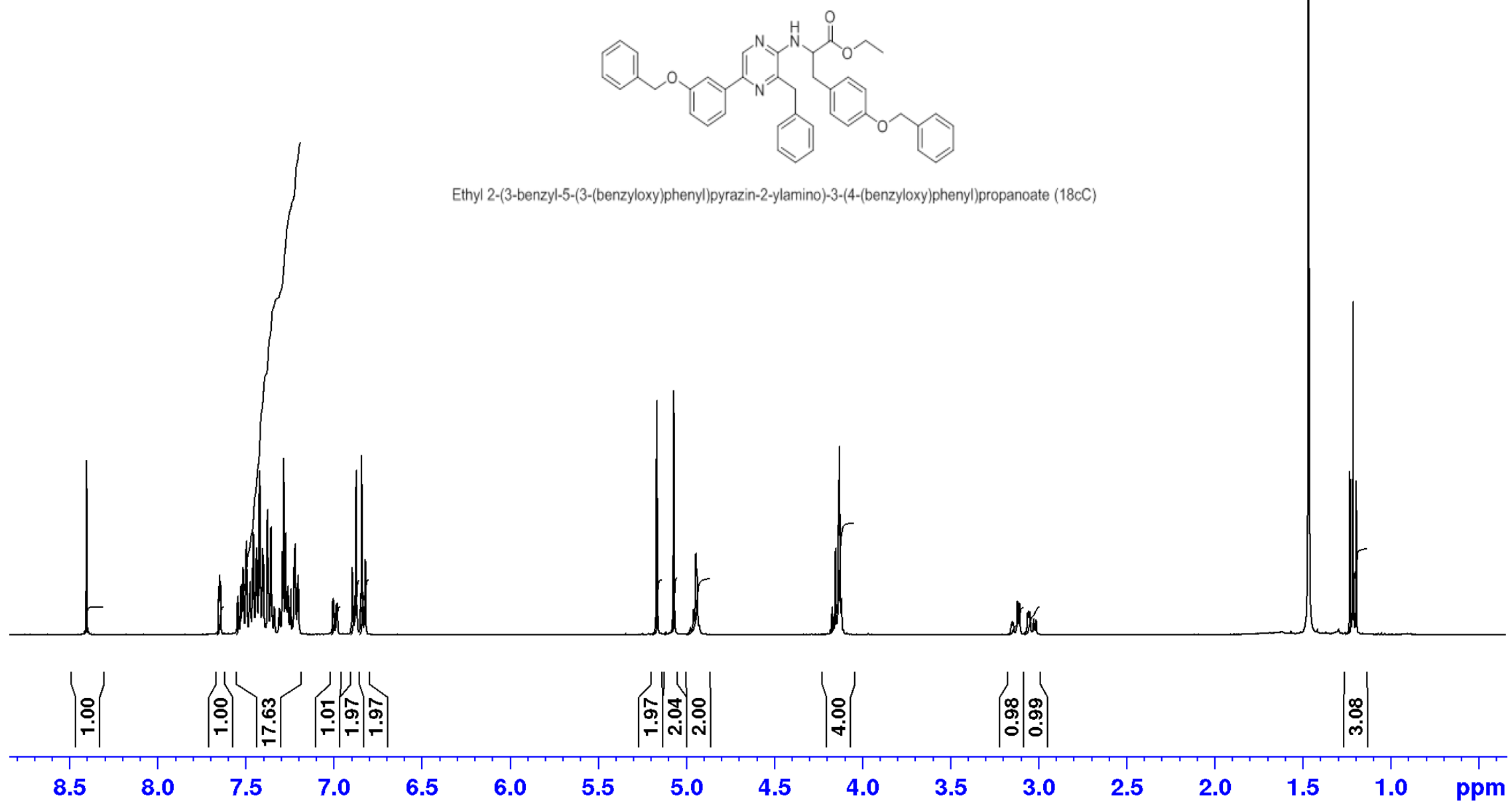





Ethyl 2-(3-benzyl-5-(3-(benzyloxy)phenyl)pyrazin-2-ylamino)-3-(4-(benzyloxy)phenyl)propanoate (18cC)

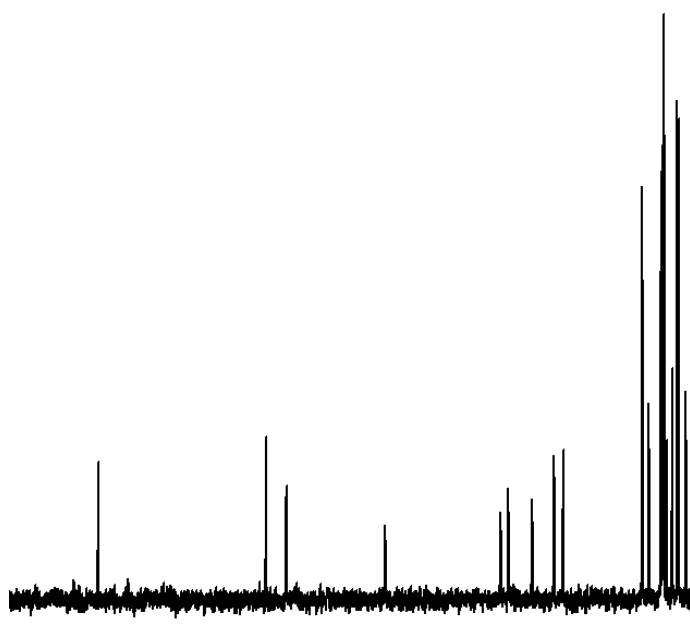

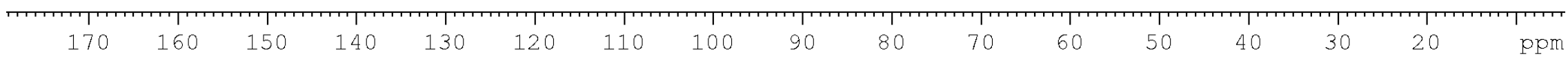



ppm

106 


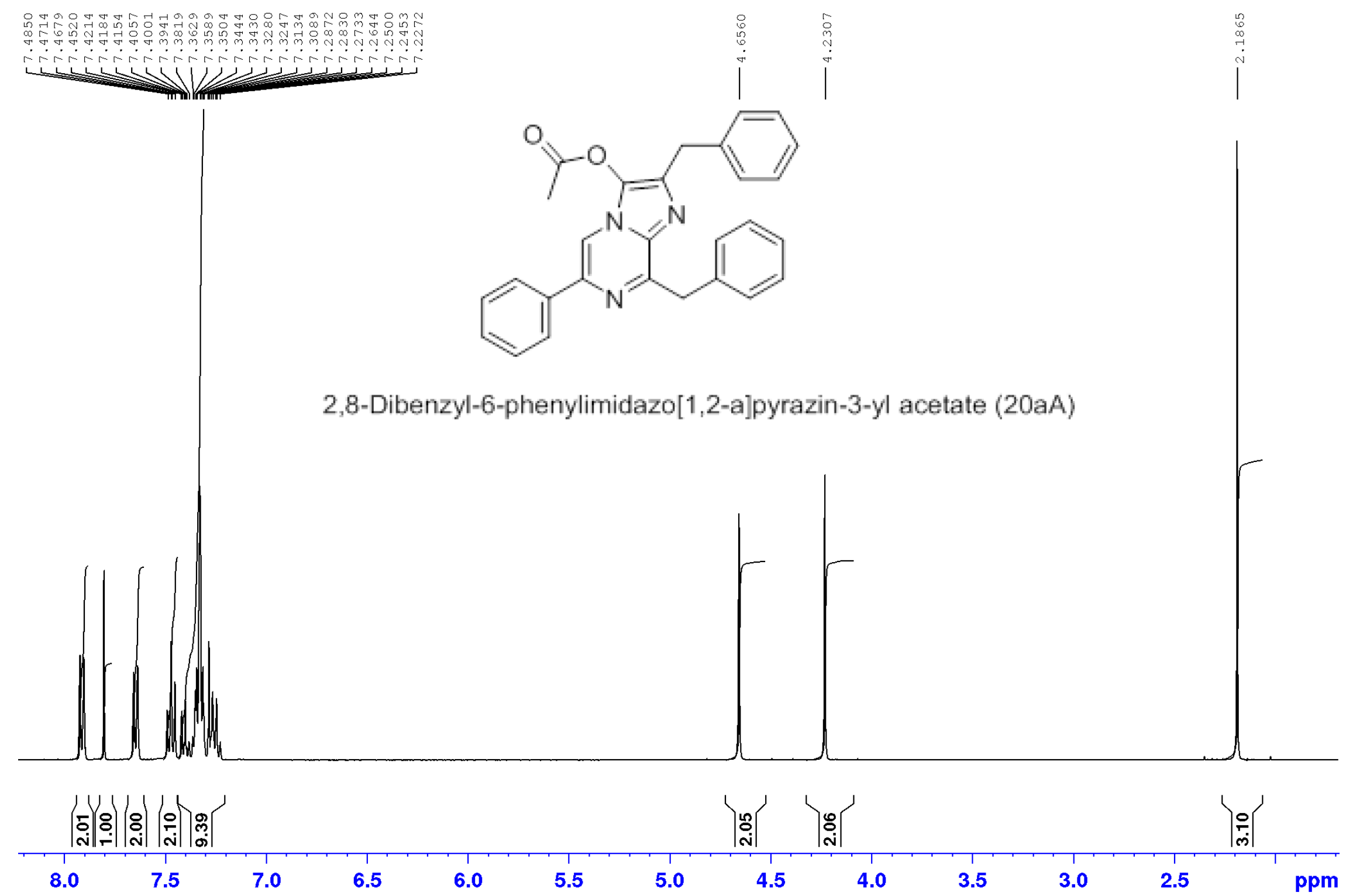




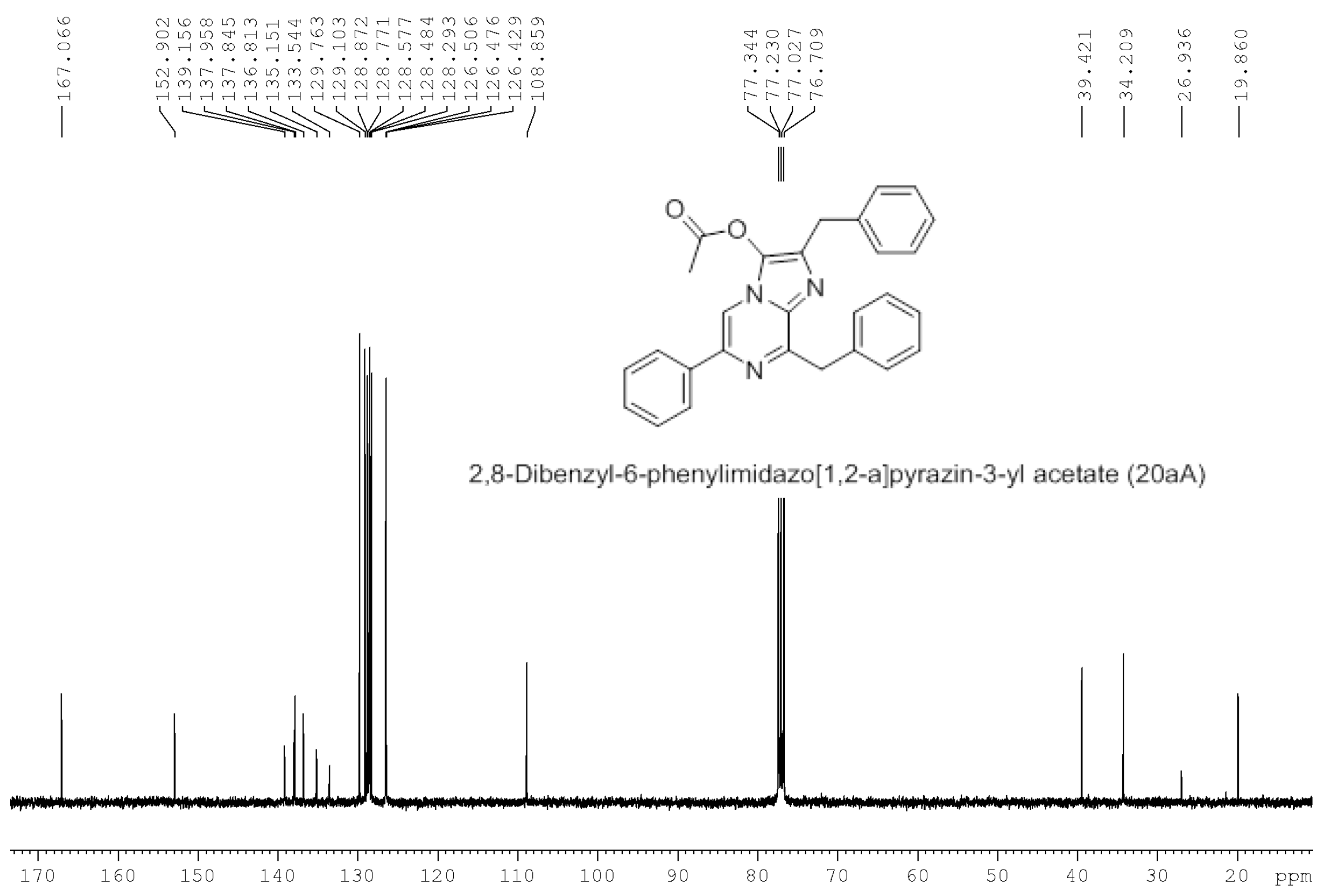




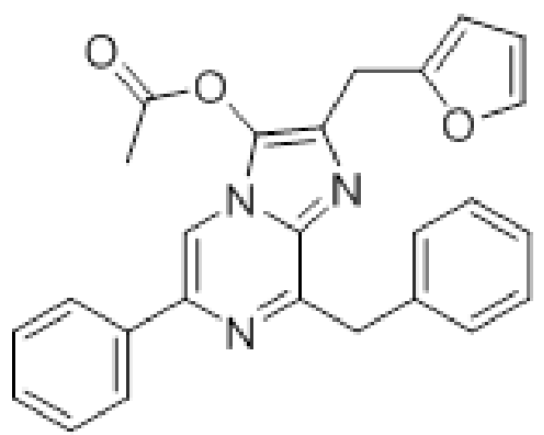

8-benzyl-2-(furan-2-ylmethyl)-6-phenylimidazo[1,2-a]pyrazin-3-yl acetate (20aB)

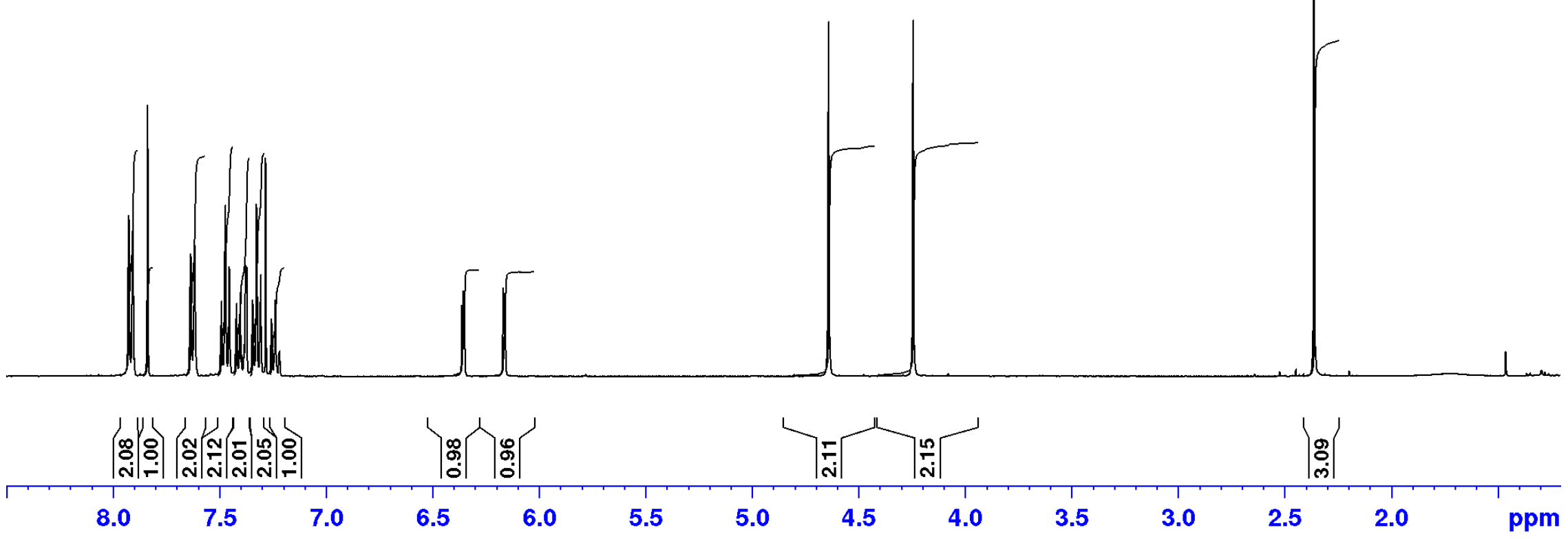




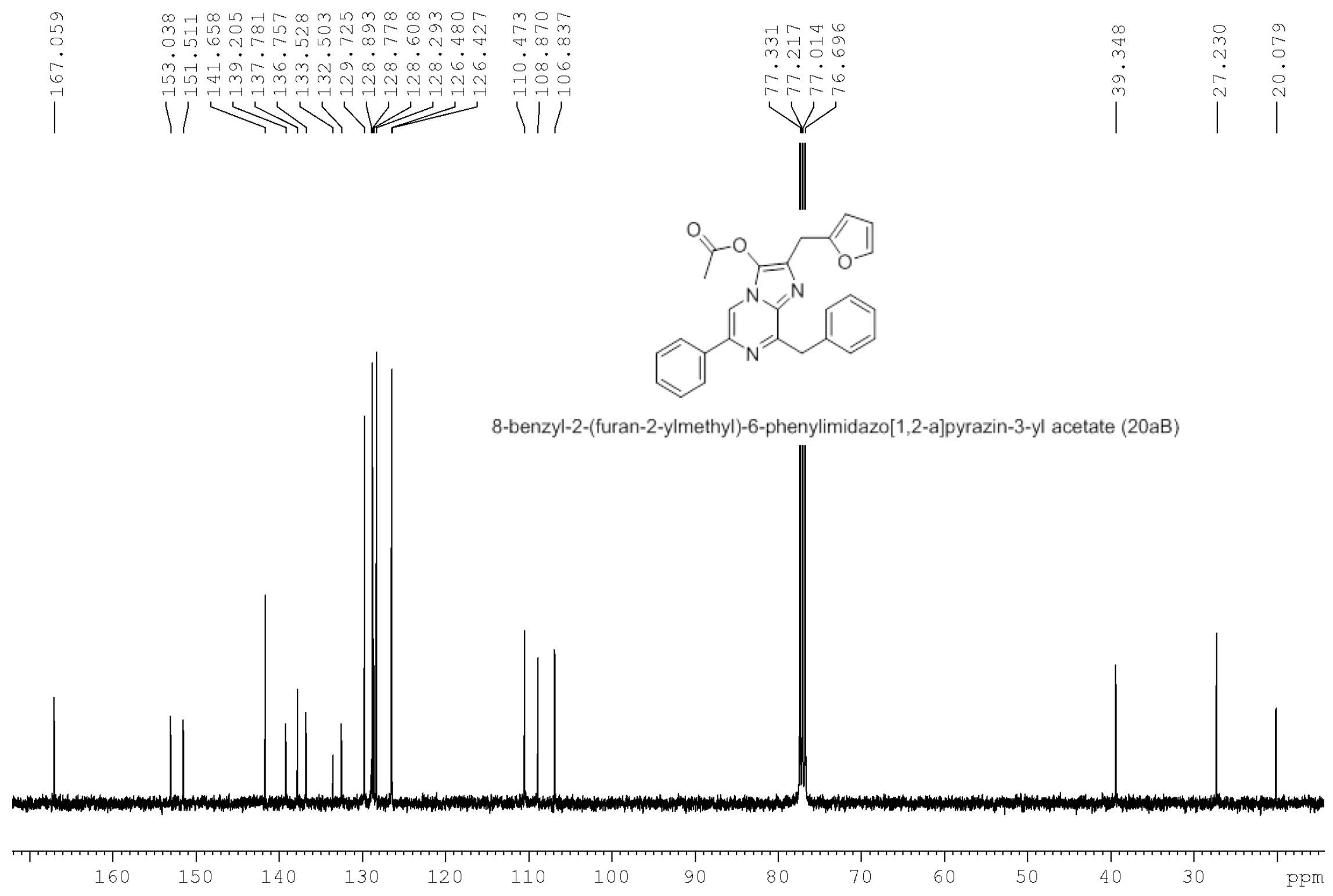




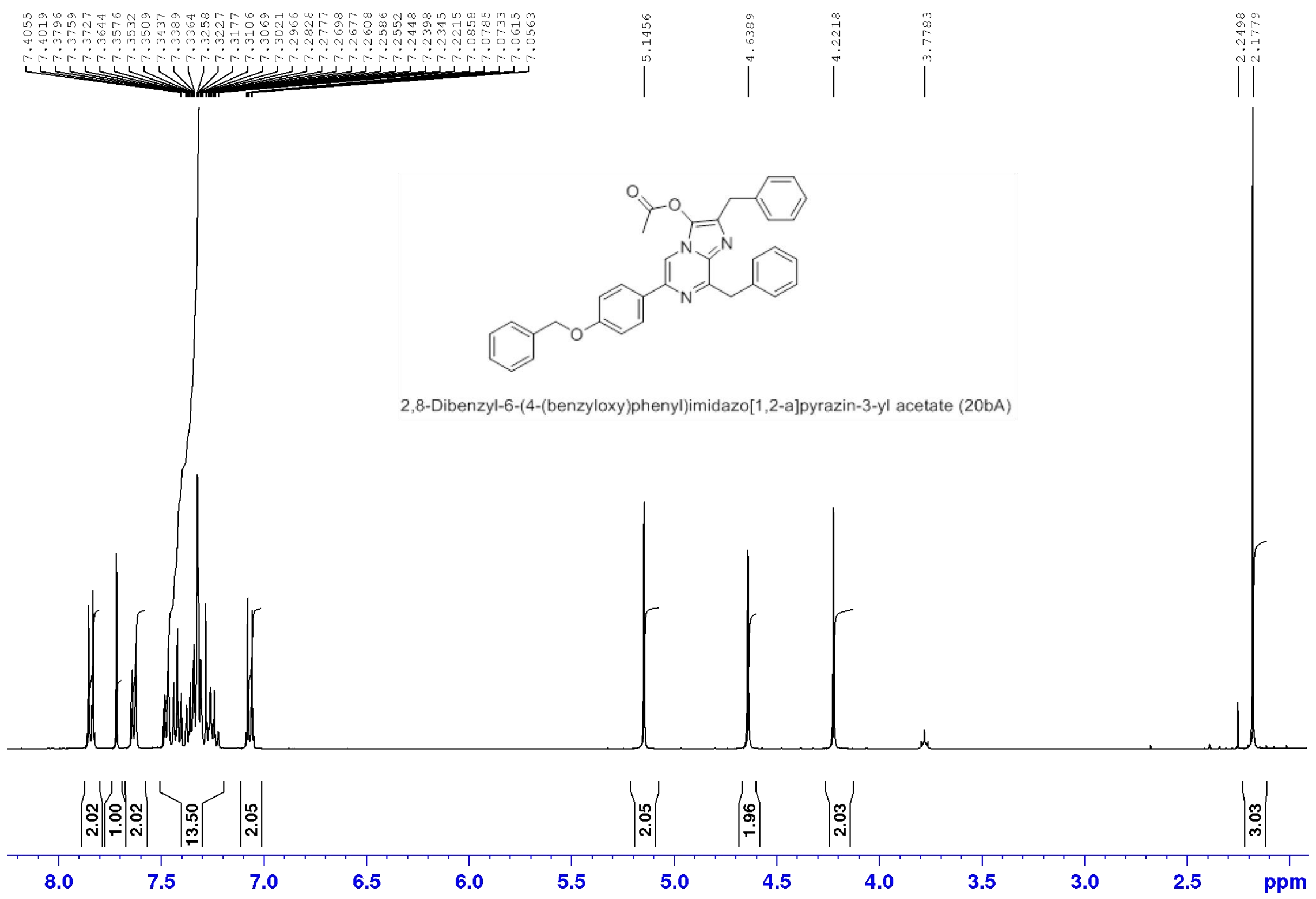




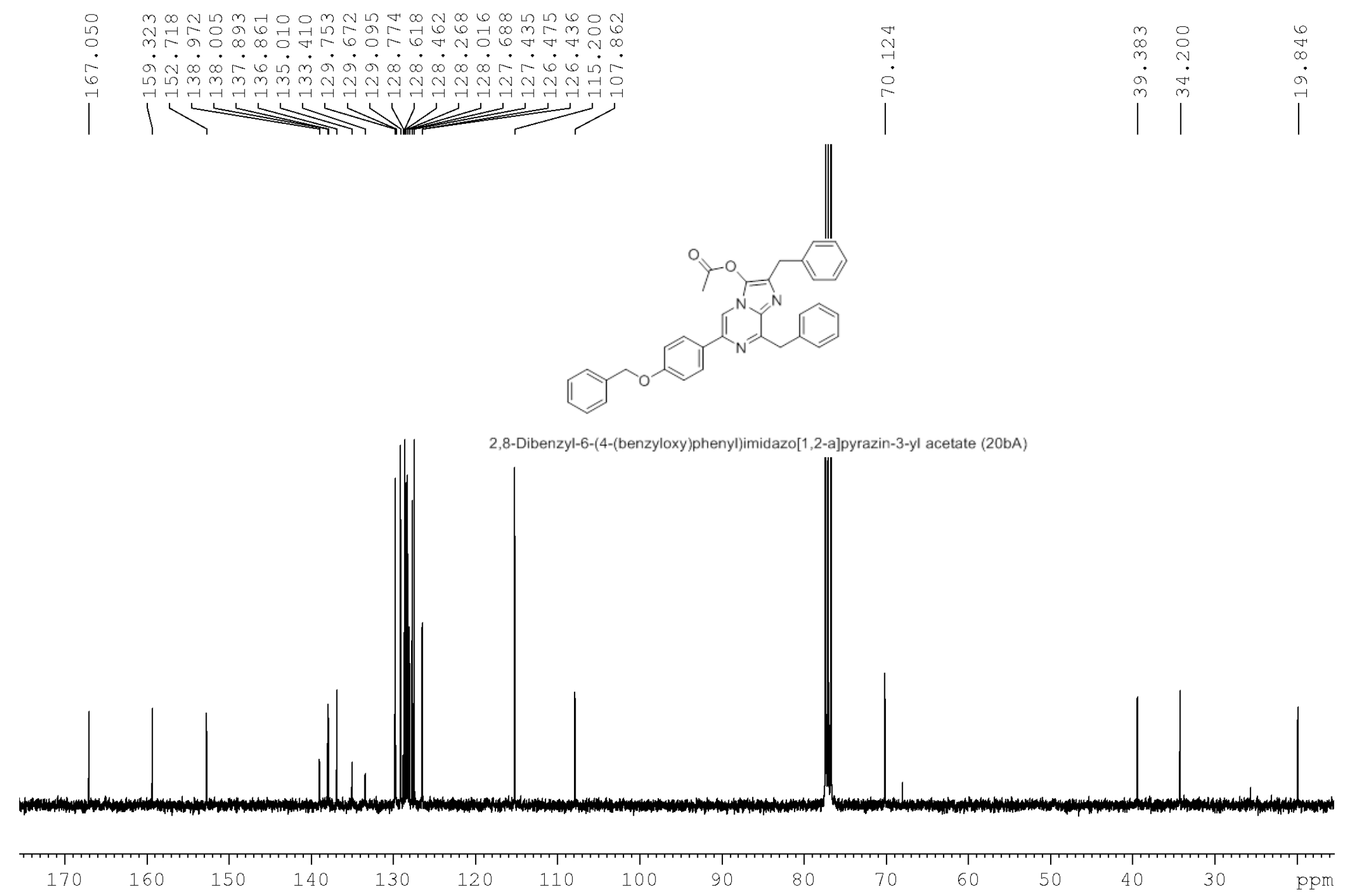




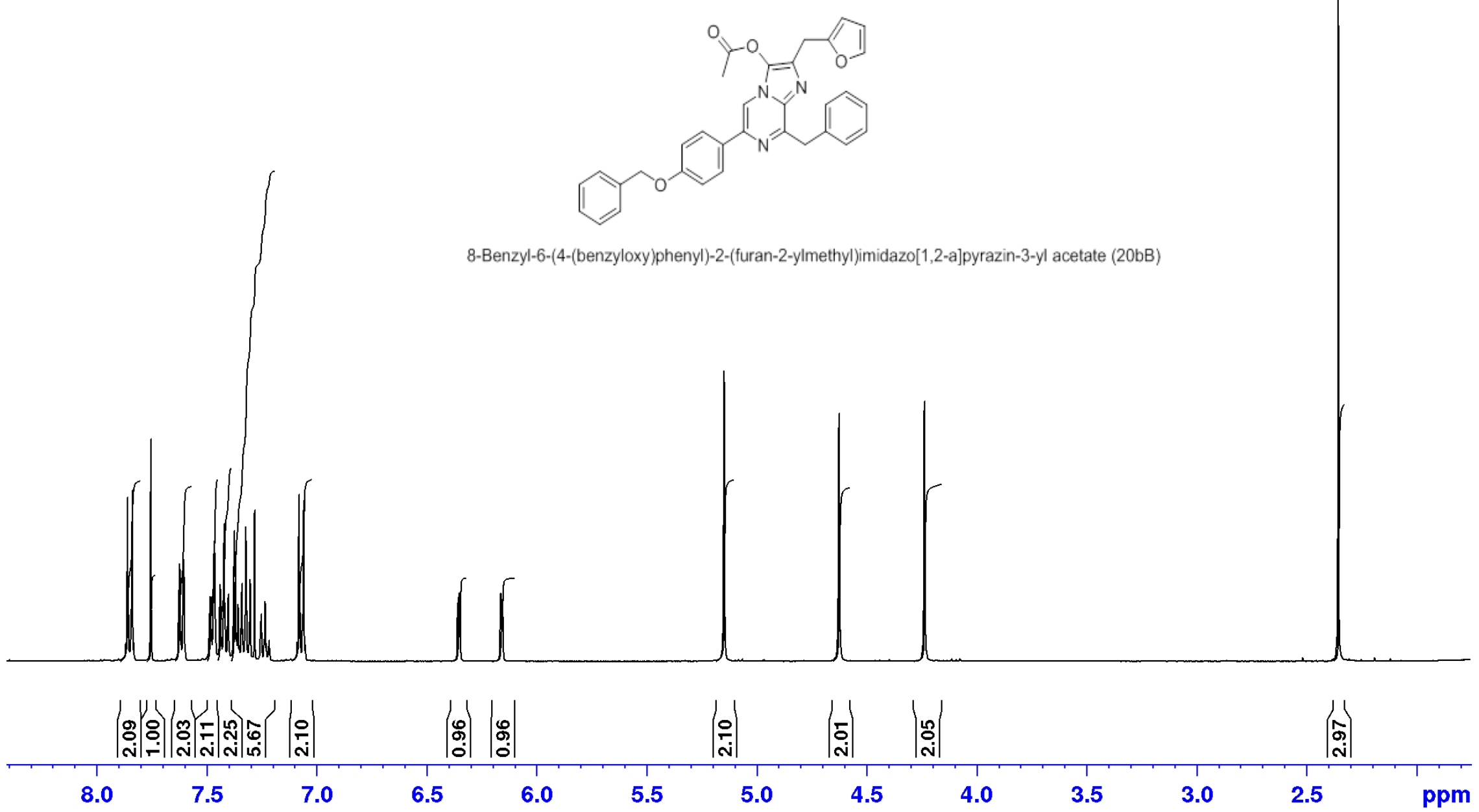



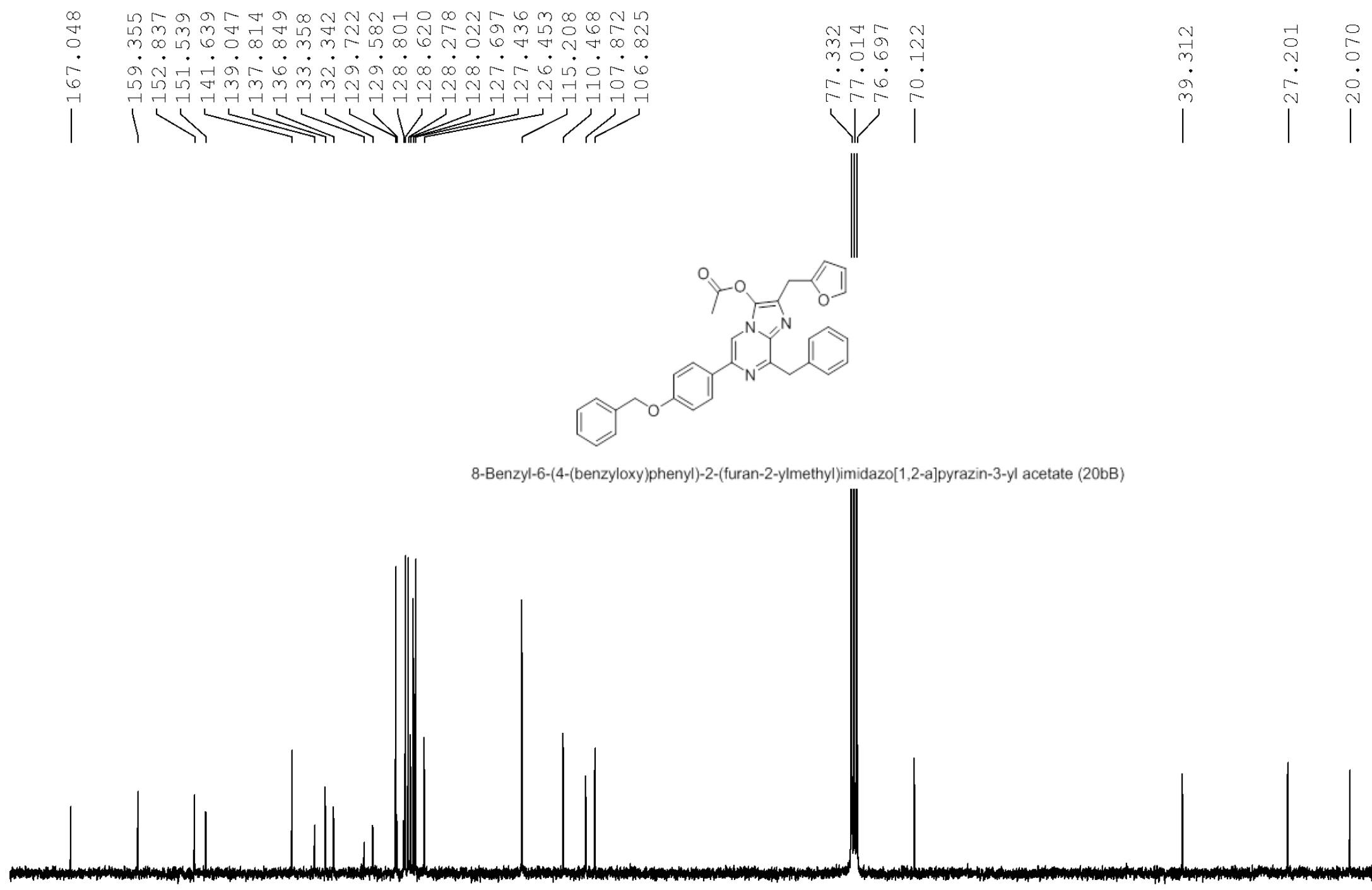

8-Benzyl-6-(4-(benzyloxy)phenyl)-2-(furan-2-ylmethyl)imidazo[1,2-a]pyrazin-3-yl acetate (20bB)



114 


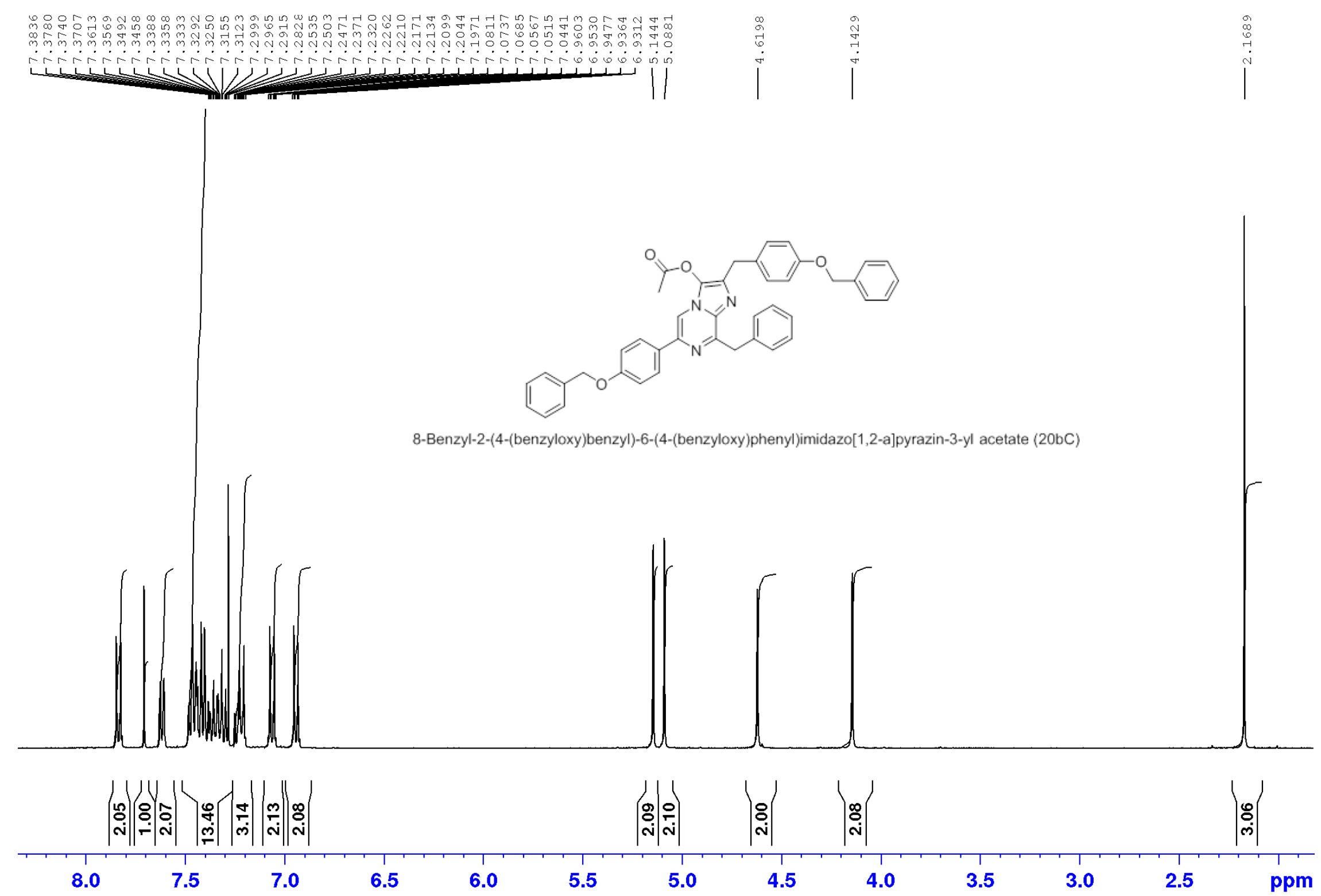




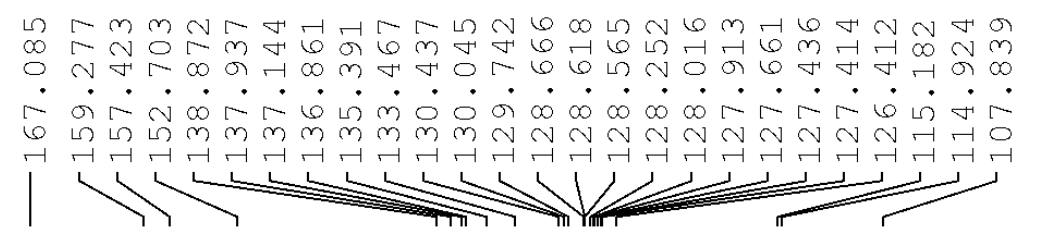

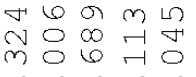

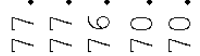

$1 / V$

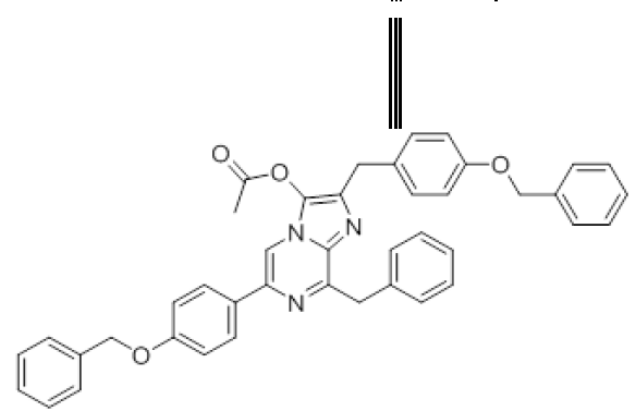

8-Benzyl-2-(4-(benzyloxy)benzyl)-6-(4-(benzyloxy)phenyl)imidazo[1, 2-a]pyrazin-3-yl acetate (20bC)






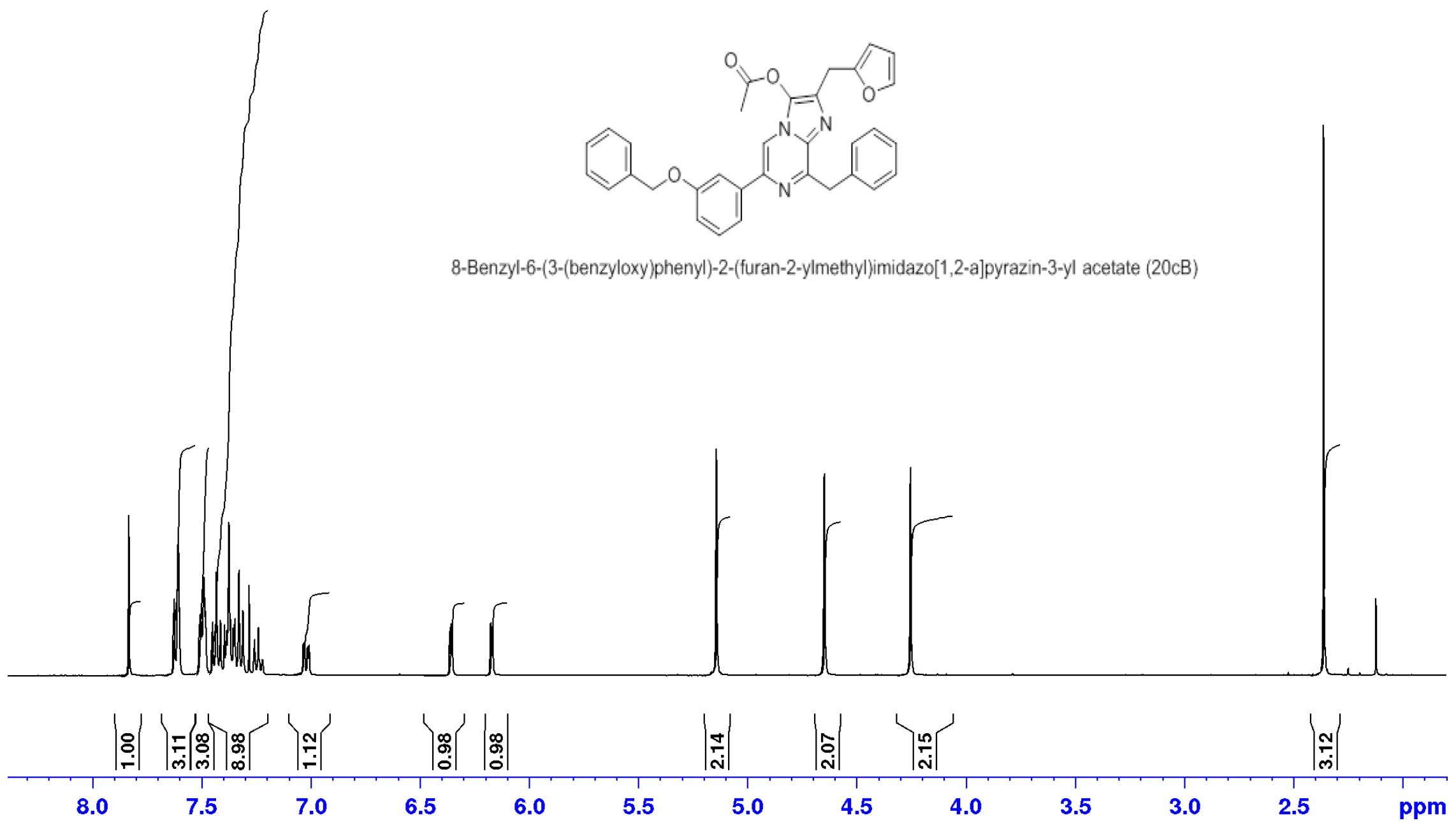


の

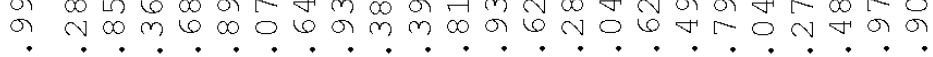

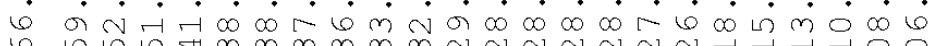



1



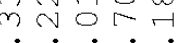

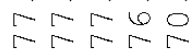

(

‥

$i^{m} V^{N}$

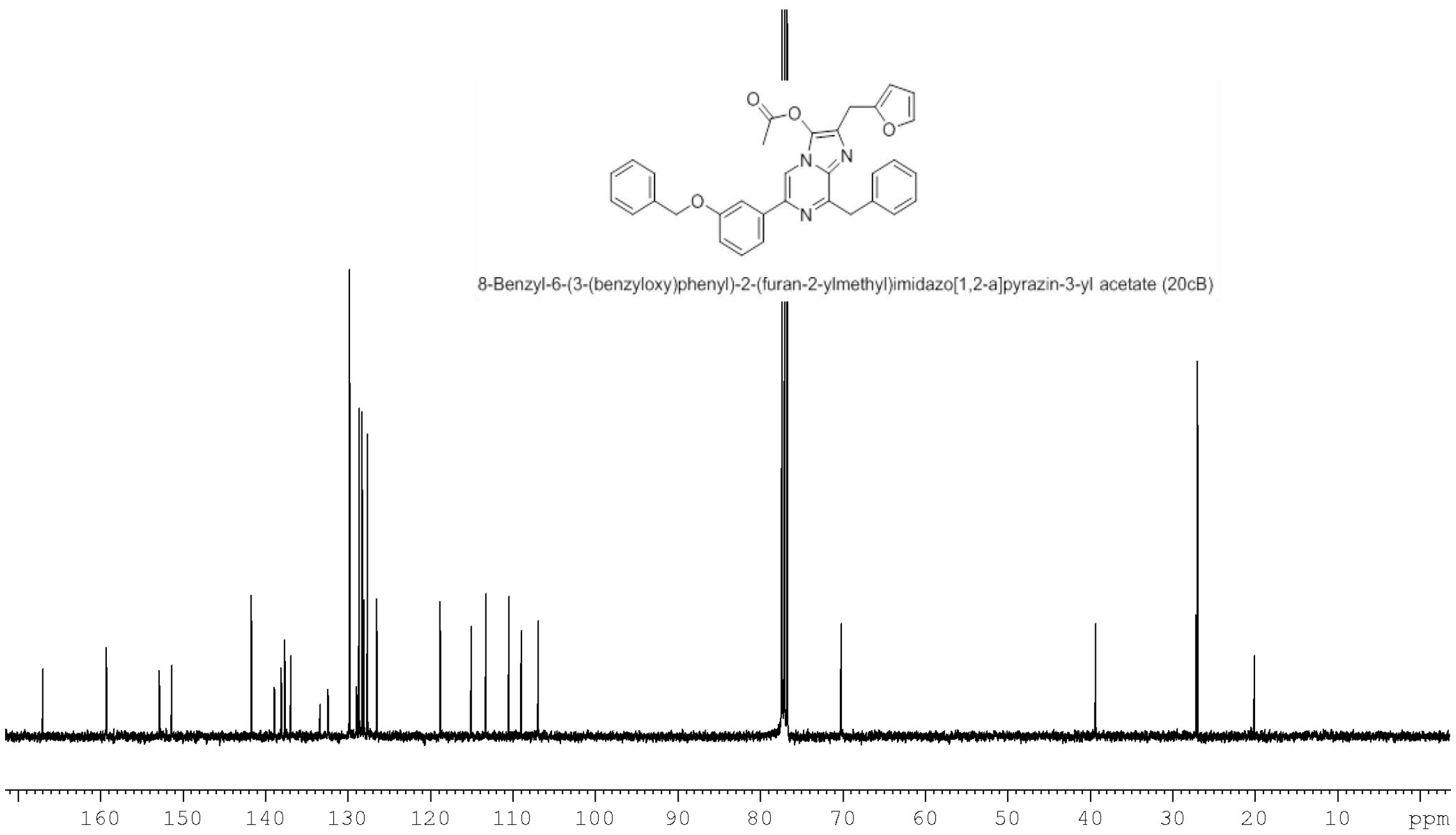




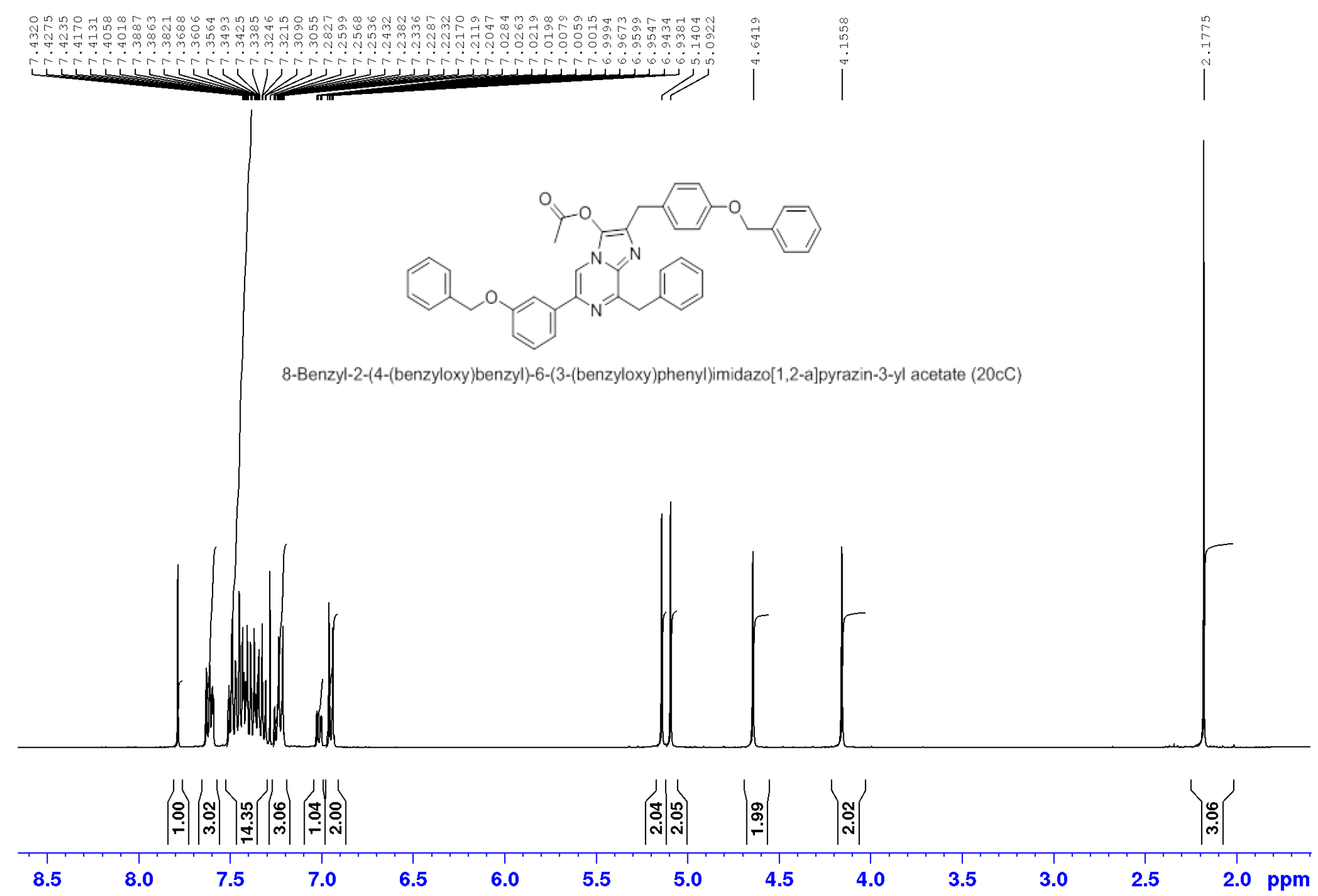



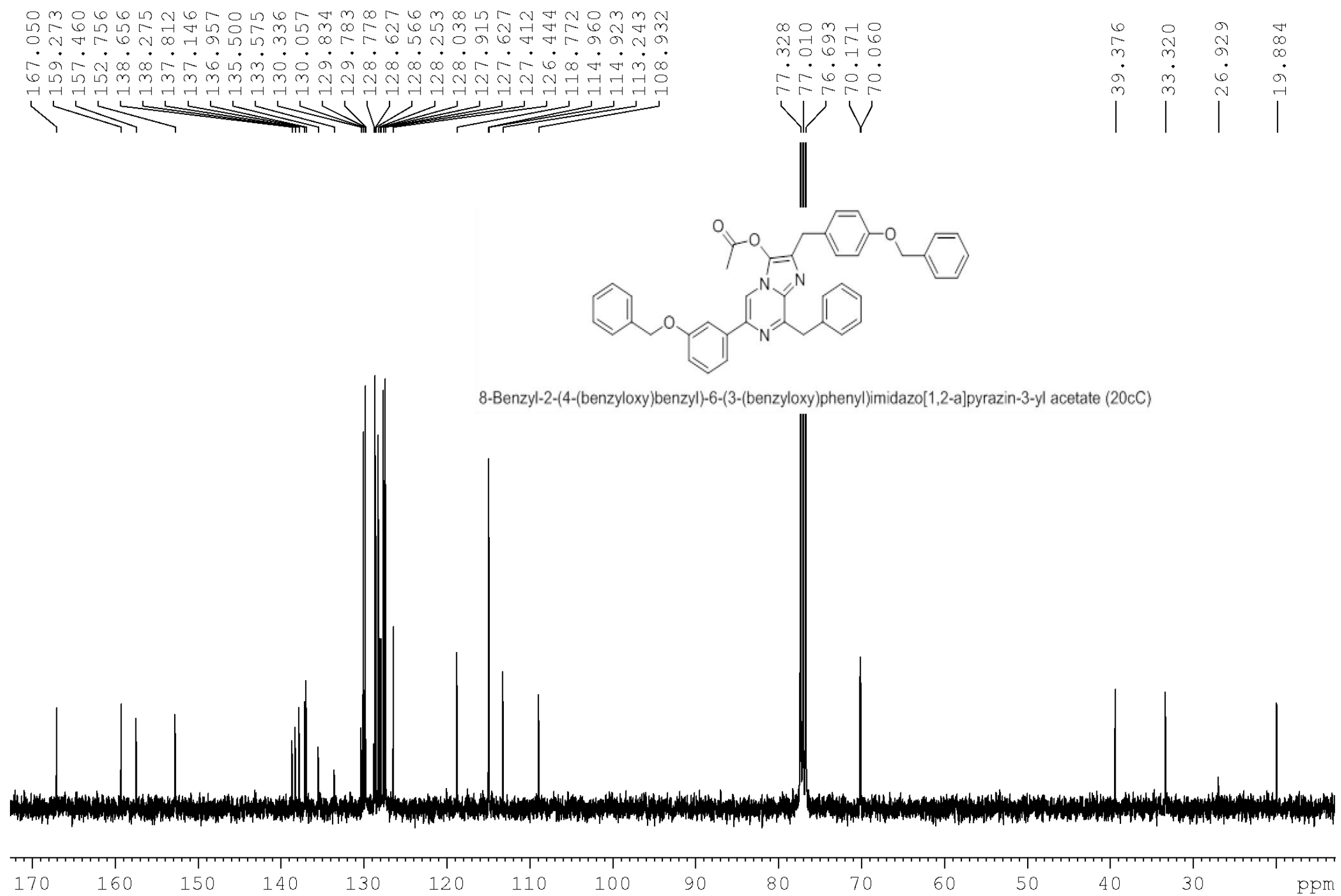


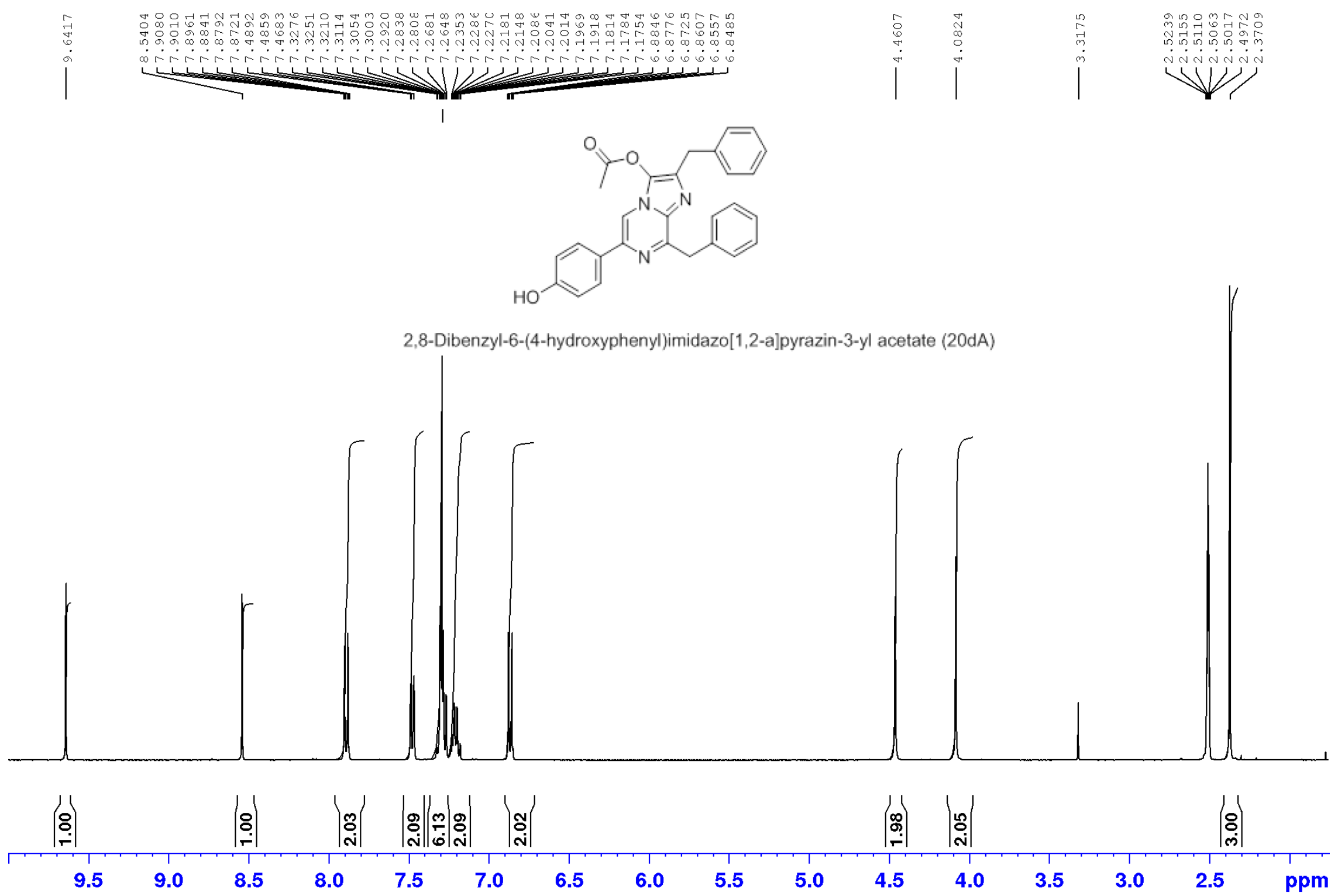




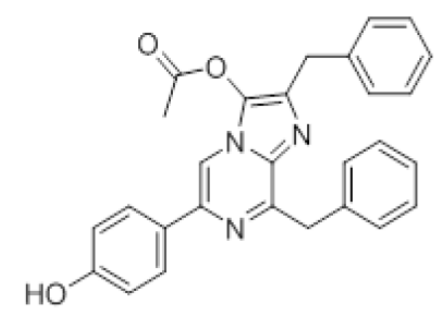

2,8-Dibenzyl-6-(4-hydroxyphenyl)imidazo[1,2-a]pyrazin-3-yl acetate (20dA)

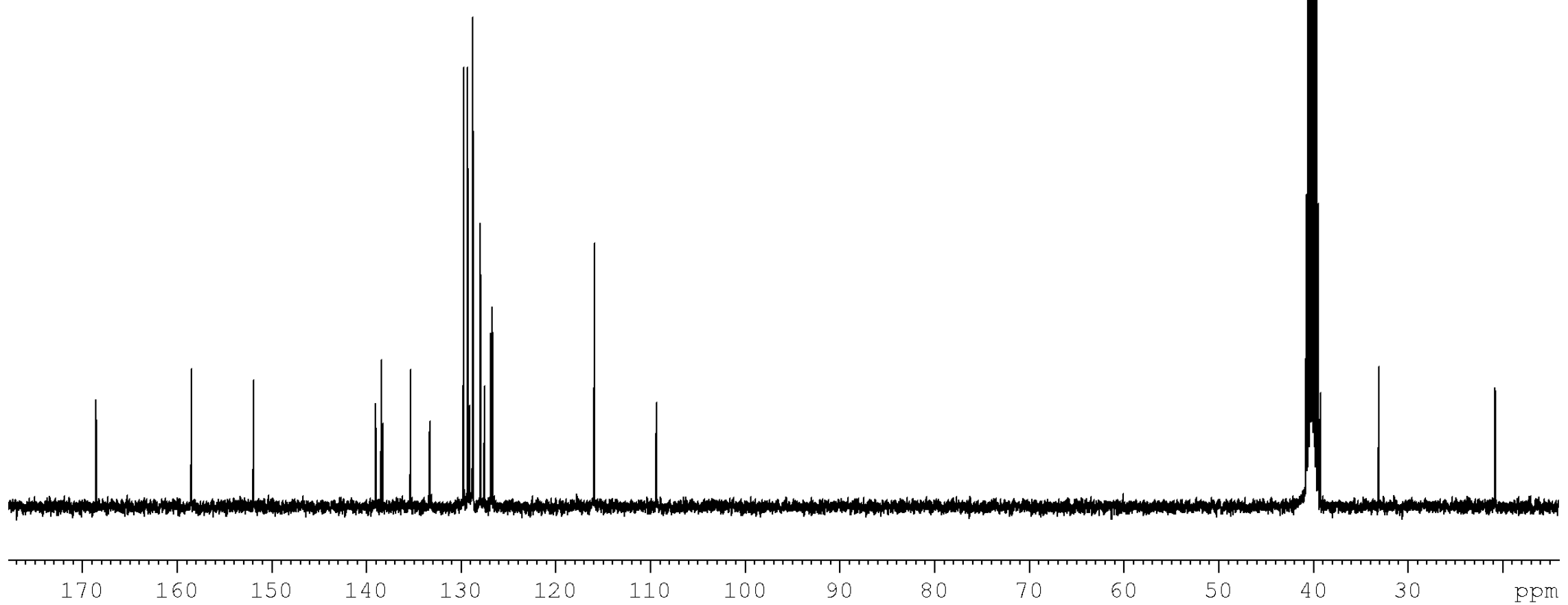




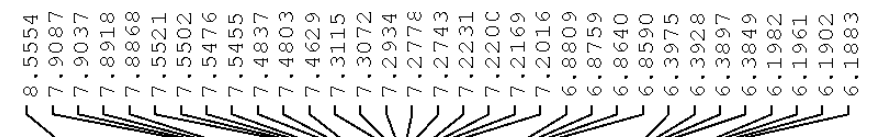

8-Benzyl-2-(furan-2-ylmethyl)-6-(4-hydroxyphenyl)imidazo[1,2-a]pyrazin-3-yl acetate (20dB)

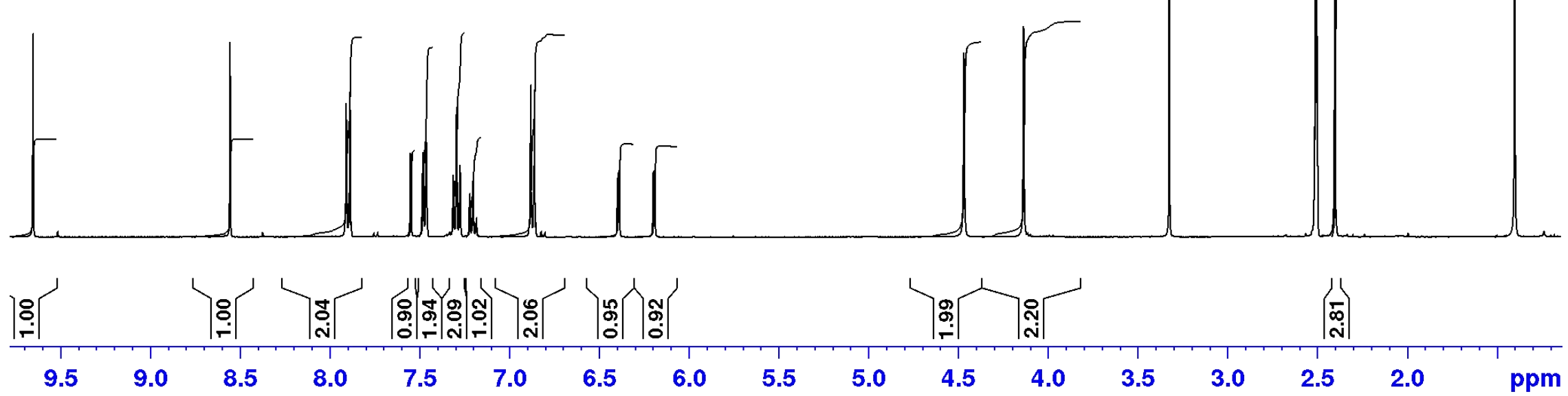



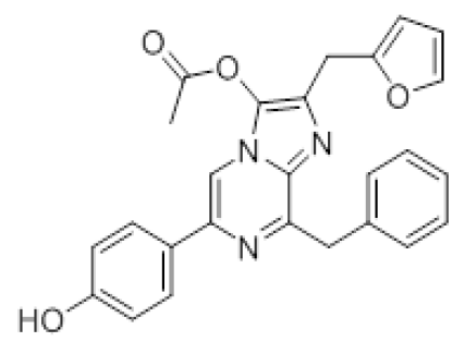

8-Benzyl-2-(furan-2-ylmethyl)-6-(4-hydroxyphenyl)imidazo[1,2-a]pyrazin-3-yl acetate (20dB)

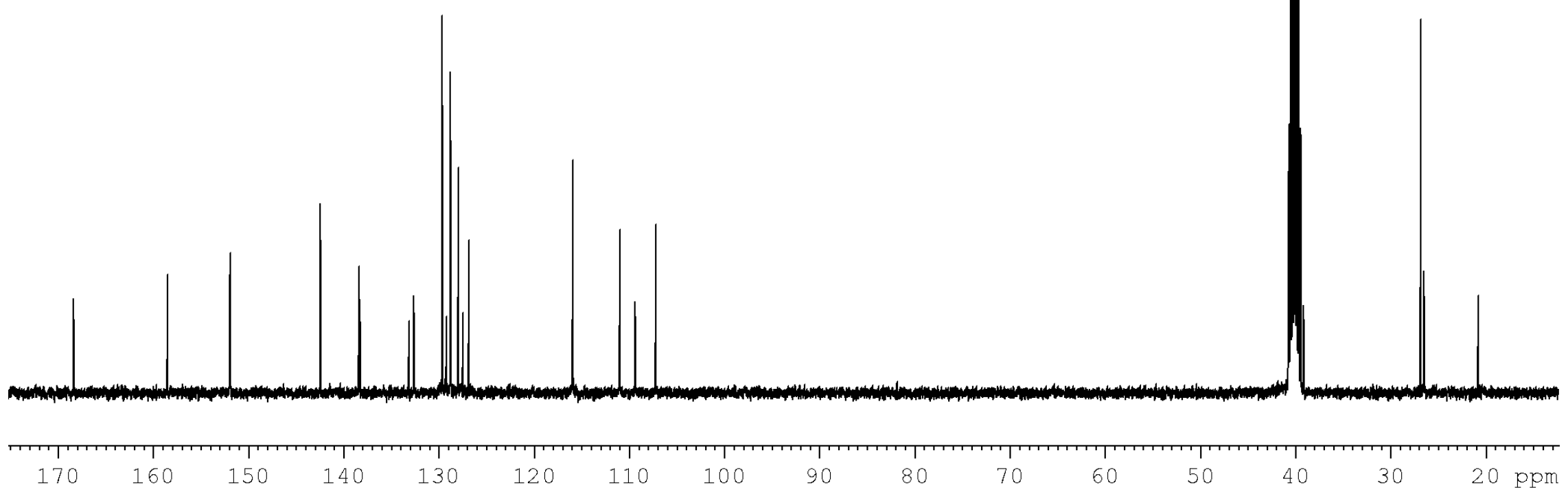



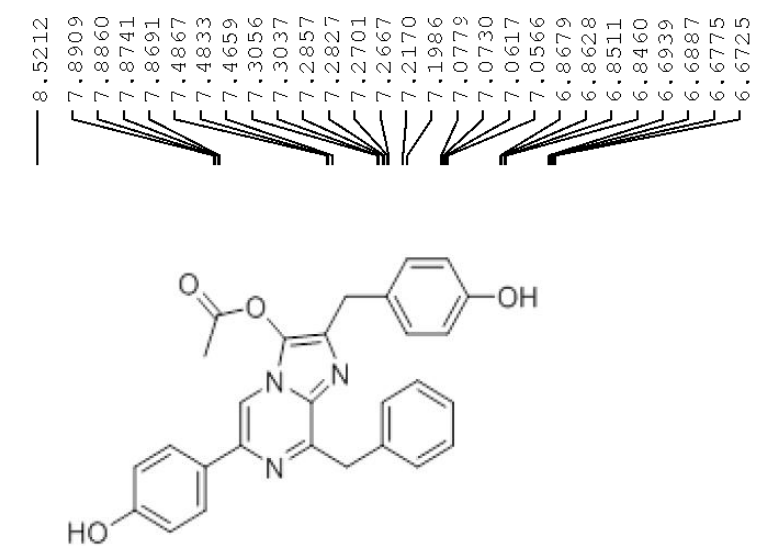

8-Benzyl-2-(4-hydroxybenzyl)-6-(4-hydroxyphenyl)imidazo[1,2-a]pyrazin-3-yl acetate (20dD)

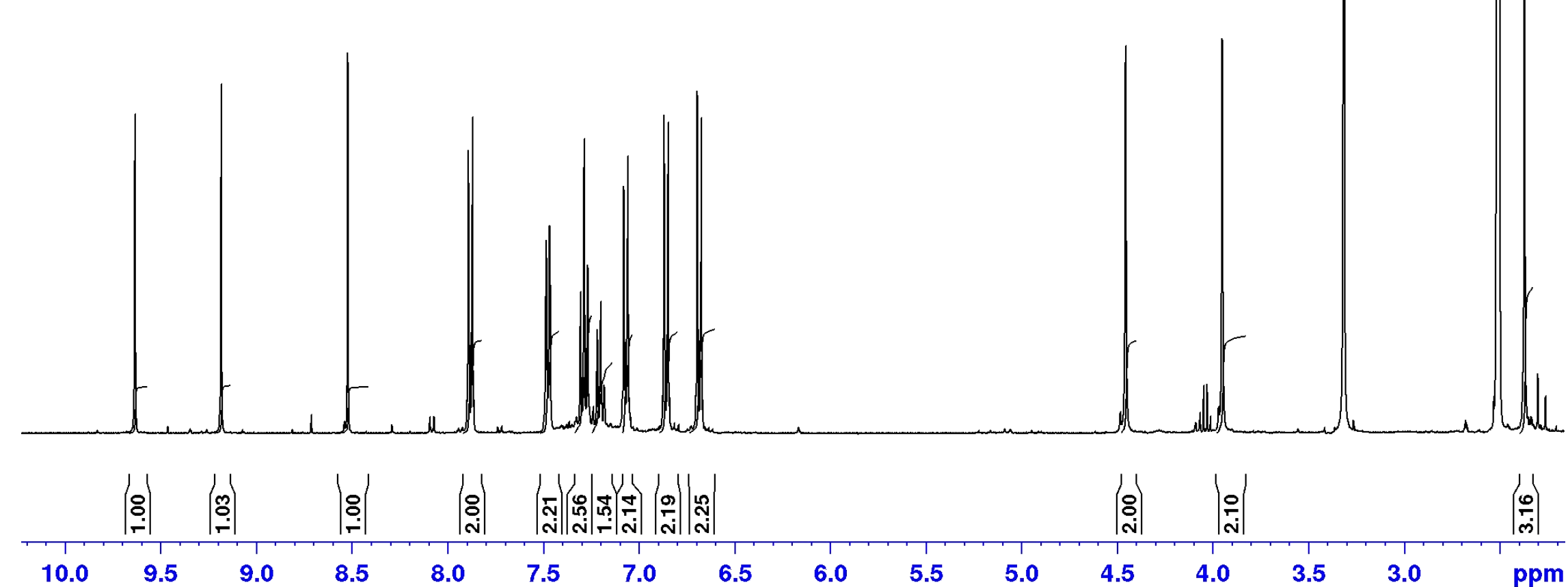



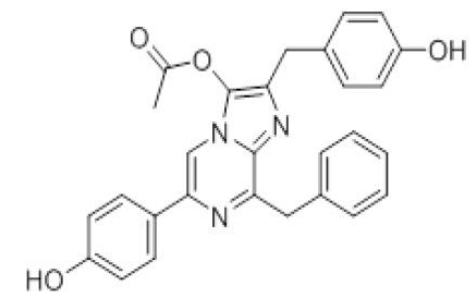

8-Benzyl-2-(4-hydroxybenzyl)-6-(4-hydroxyphenyl)imidazo[1,2-a]pyrazin-3-yl acetate (20dD)



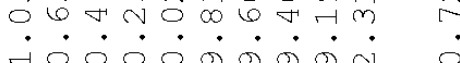

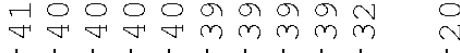

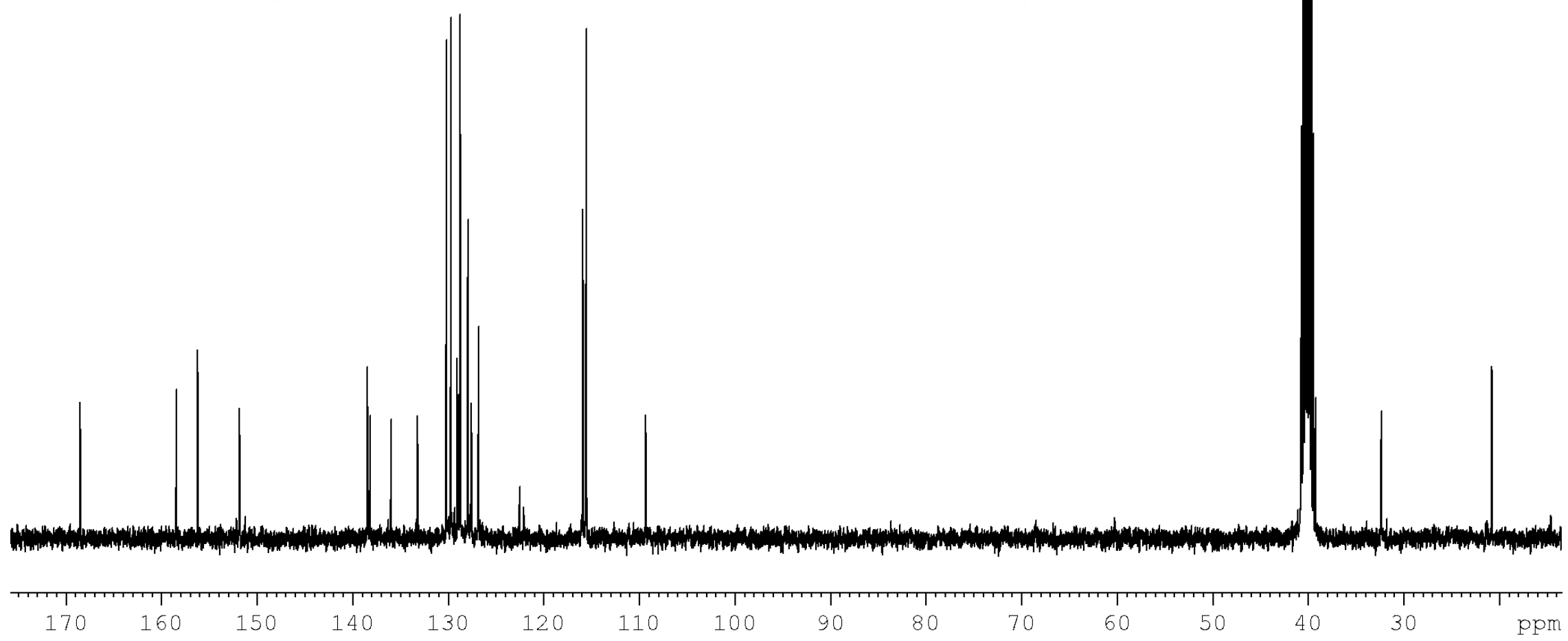



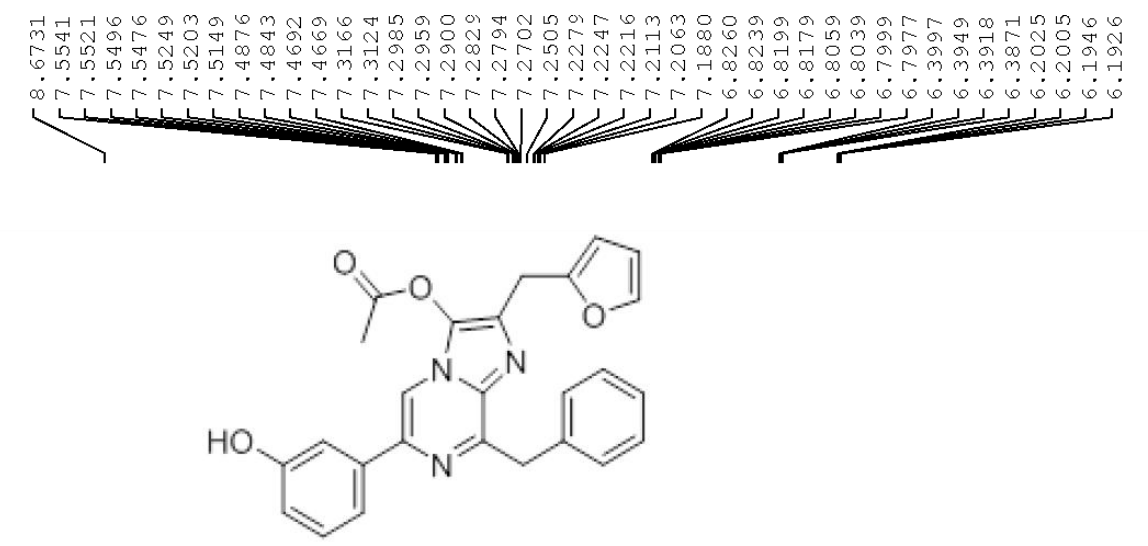

8-Benzyl-2-(furan-2-ylmethyl)-6-(3-hydroxyphenyl)imidazo[1,2-a]pyrazin-3-yl acetate (20eB)

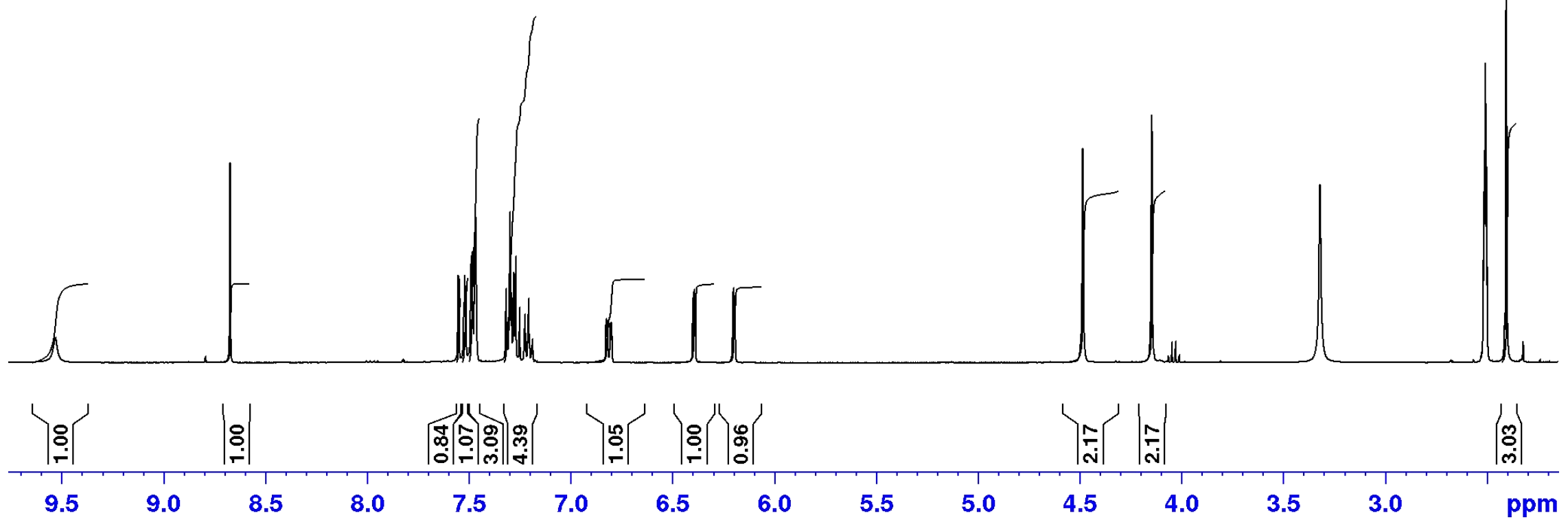




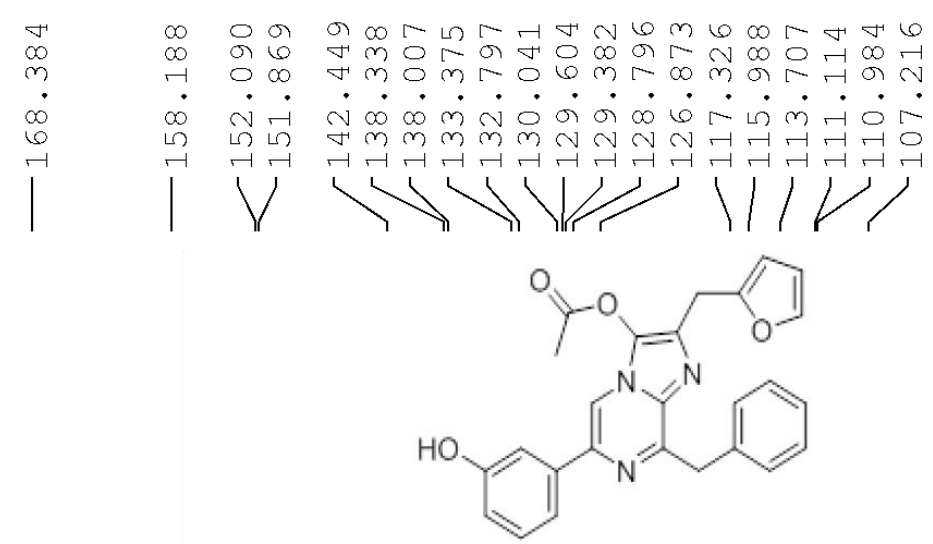

8-Benzyl-2-(furan-2-ylmethyl)-6-(3-hydroxyphenyl)imidazo[1,2-a]pyrazin-3-yl acetate (20eB)






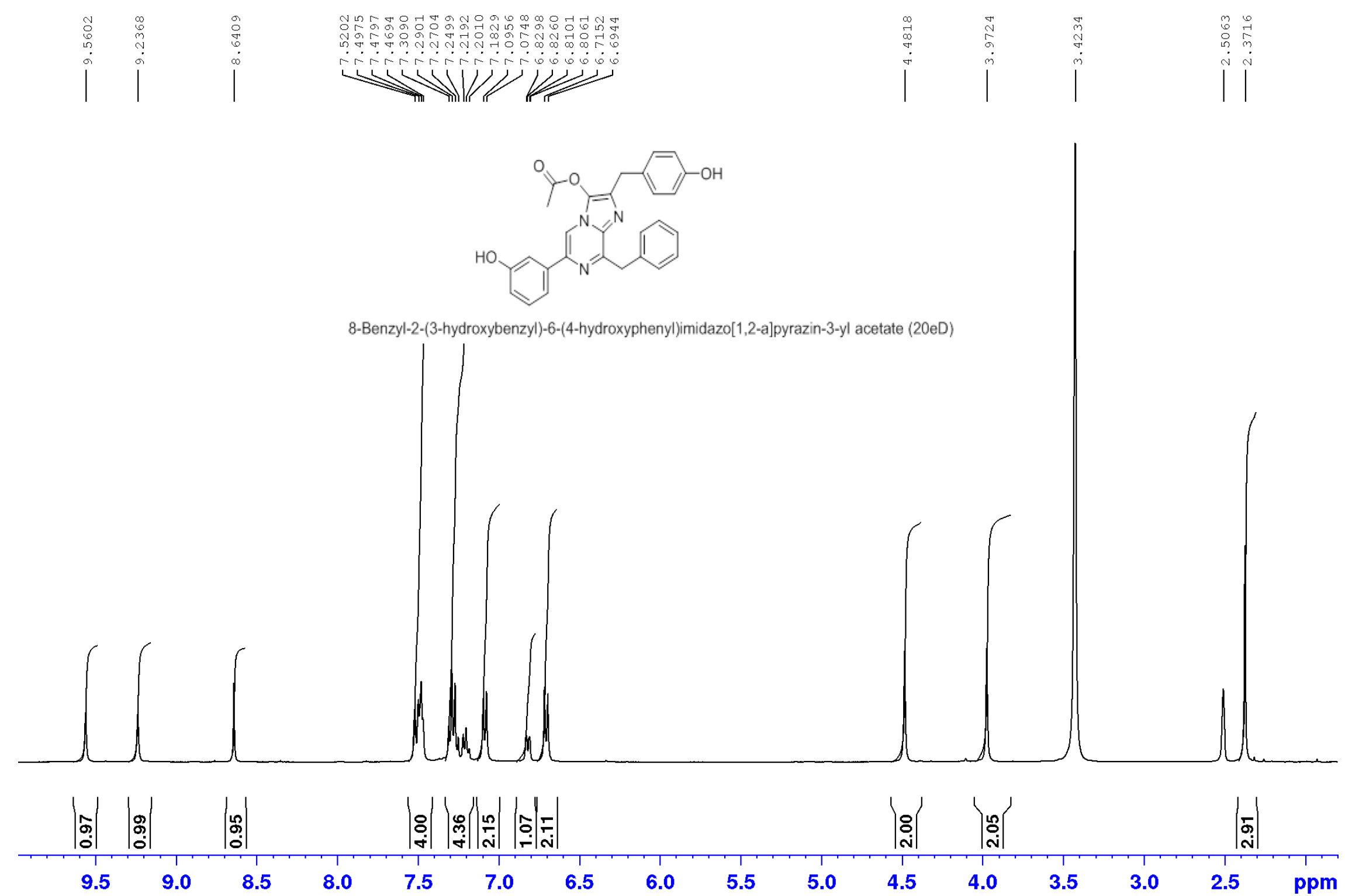




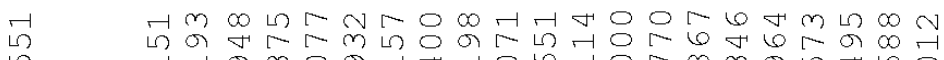

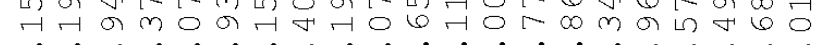

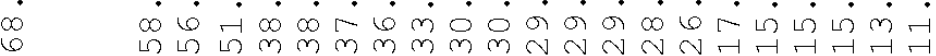

1

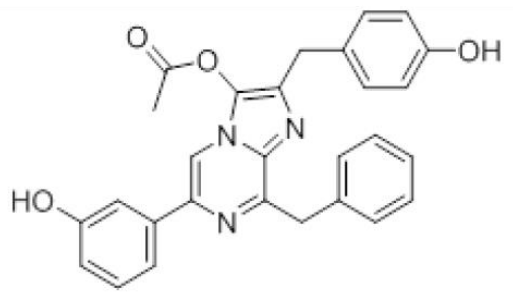

8-Benzyl-2-(3-hydroxybenzyl)-6-(4-hydroxyphenyl)imidazo[1,2-a]pyrazin-3-yl acetate (20eD)

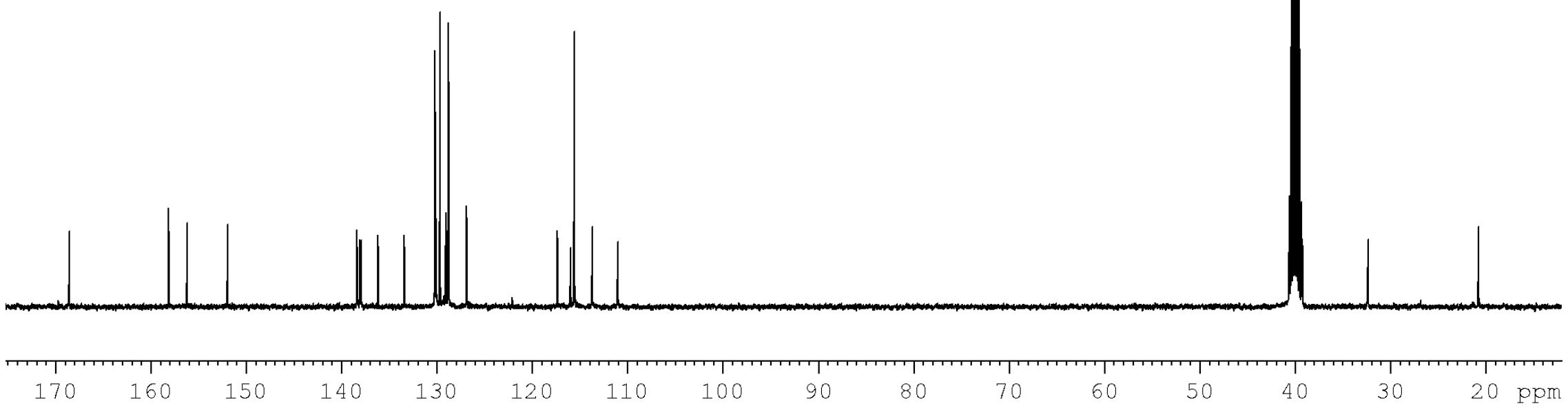

